UNIVERSIDADE DE SÃO PAULO

FACULDADE DE FILOSOFIA, LETRAS E CIÊNCIAS HUMANAS DEPARTAMENTO DE HISTÓRIA

PROGRAMA DE PÓS-GRADUAÇÃO EM HISTÓRIA ECONÔMICA

MAURICIO MILÉO CÂMARA DE OLIVEIRA

INFLUÊNCIAS DO SOCIALISMO DEMOCRÁTICO EUROPEU

E DO ESTADO DE BEM-ESTAR SOCIAL NA MILITÂNCIA

DO PARTIDO SOCIALISTA BRASILEIRO, 1945-1950

São Paulo

2016 
MAURICIO MILÉO CÂMARA DE OLIVEIRA

\section{INFLUÊNCIAS DO SOCIALISMO DEMOCRÁTICO EUROPEU \\ E DO ESTADO DE BEM-ESTAR SOCIAL NA MILITÂNCIA \\ DO PARTIDO SOCIALISTA BRASILEIRO, 1945-1950}

Dissertação apresentada ao Programa de PósGraduação em História Econômica da Faculdade de Filosofia, Letras e Ciências Humanas da Universidade de São Paulo, como requisito parcial à obtenção do título de mestre em História Econômica.

Orientador: Prof. Dr. Renato Perim Colistete

São Paulo

2016 


\section{FICHA CATALOGRÁFICA}

Autorizo a reprodução e divulgação total ou parcial deste trabalho, por qualquer meio convencional ou eletrônico, para fins de estudo e pesquisa, desde que citada a fonte.

Catalogação na Publicação

Serviço de Biblioteca e Documentação

Faculdade de Filosofia, Letras e Ciências Humanas da Universidade de São Paulo

Miléo, Mauricio
M64i Influências do Socialismo Democrático Europeu e do Estado de Bem-Estar Social na Militância do

Partido Socialista Brasileiro, 1945-1950 / Mauricio

Miléo ; orientador Renato Perim Colistete. - São

Paulo, 2016.

$190 \mathrm{f}$

Dissertação (Mestrado) - Faculdade de Filosofia, Letras e Ciências Humanas da Universidade de Săo

Paulo. Departamento de História. Area de concentração: História Econômica.

1. Estado de Bem-Estar Social. 2. Partido

Socialista Brasileiro. 3. Socialismo Democrático. I. Colistete, Renato Perim, orient. II. Titulo. 


\author{
INFLUÊNCIAS DO SOCIALISMO DEMOCRÁTICO EUROPEU \\ E DO ESTADO DE BEM-ESTAR SOCIAL NA MILITÂNCIA \\ DO PARTIDO SOCIALISTA BRASILEIRO, 1945-1950
}

Dissertação apresentada ao Programa de Pós-
Graduação em História Econômica da Faculdade de
Filosofia, Letras e Ciências Humanas da
Universidade de São Paulo, como requisito parcial à
obtenção do título de mestre em História Econômica.

Aprovado em:

Banca Examinadora:

Prof. Dr.

Instituição: Julgamento:

Assinatura:

Prof. Dr.

Instituição: Julgamento:

Assinatura:

Prof. Dr.

Instituição: Julgamento:

Assinatura: 
Dedico este trabalho a Ivan Miléo de Miranda. 
Agradecimentos:

Ao meu orientador, professor doutor Renato Perim Colistete, pelas orientações que balizaram minhas reflexões, a atenção cuidadosa, a honestidade intelectual e a paciência;

Aos funcionários do Departamento de História da Faculdade de Filosofia, Letras e Ciências Humanas da USP; da Biblioteca Florestan Fernandes da mesma Faculdade; e da Biblioteca da Faculdade de Economia e Administração da USP;

Aos profissionais do Centro de Documentação e Memória da Universidade Estadual de São Paulo; do Arquivo Público do Estado de São Paulo; e do Arquivo Público do Estado do Rio de Janeiro pela solicitude com que me proporcionaram o acesso a materiais indispensáveis para a realização da minha pesquisa;

À Coordenação de Aperfeiçoamento de Pessoal de Nível Superior pela bolsa a mim concedida durante um período importante da preparação deste trabalho.

A Felipe Pereira Loureiro e Fernando Monteiro Rugitsky, cujas valiosas críticas oferecidas durante a minha qualificação foram fundamentais no curso das reflexões apresentadas neste trabalho;

A Josefina Neves Mello pela revisão e atualização ortográfica do texto;

A Vera, Leila, Carlos Alberto e Leo, família de leais amigos, cujas excelentes discussões e recomendações têm sido de imensurável valor na minha trajetória acadêmica;

A Sidney, Madalena, Analena e Maria. Minha família, a quem devo o imprescindível suporte. 
"O que se pensa que é face humana do capitalismo é o que o socialismo arrancou dele com suor, lágrimas e sangue."

Antonio Cândido. 


\section{RESUMO}

MILEO, Mauricio. Influências do Socialismo Democrático Europeu e do Estado de Bem-Estar Social na Militância do Partido Socialista Brasileiro, 1945-1950. (190f.). Orientador: Prof. Dr. Renato Perim Colistete. Dissertação (Mestrado em História Econômica). São Paulo: Universidade de São Paulo, 2016.

O objeto desta dissertação é a perspectiva teórica e política elaborada pelo Partido Socialista Brasileiro entre 1945 e 1950, em particular sua relação com as teses do socialismo democrático e com o advento do Estado de Bem-Estar Social na Europa. São analisados os problemas enfrentados pela organização partidária, os dilemas políticos e as contribuições teóricas dos socialistas no imediato pós-guerra. A partir da pesquisa dos documentos do partido, da imprensa socialista e dos jornais da época, busca-se configurar de que modo os socialistas brasileiros procuraram construir um projeto próprio de democracia associada à ampliação de direitos sociais. Ao mesmo tempo, são discutidas as formas com as quais se flertava com a possibilidade da formação de um terceiro campo socialista internacional, em contraposição aos monopólios capitalistas e ao comunismo de tipo soviético.

Palavras-chave: Estado de Bem-Estar Social; Partido Socialista Brasileiro; Socialismo democrático. 


\begin{abstract}
MILEO, Mauricio. Influences of the European Democratic Socialism and of the Welfare State on the Brazilian Socialist Party, 1945-1950. (190f.). Advisor: Prof. Dr. Renato Perim Colistete. Dissertation (Masters in Economic History). São Paulo: Universidade de São Paulo, 2016.

The purpose of this dissertation is the theoretical and political perspective developed by the Brazilian Socialist Party between 1945 and 1950, in particular regarding the thesis of democratic socialism and the advent of the Welfare State in Europe. The problems faced by the party organization, political dilemmas and theoretical contributions of the Socialists in the immediate postwar era are analyzed. From the research party documents, the socialist press and the newspapers of the time, it seeks to establish which way the Brazilian socialists have sought to build their own democracy project associated with the expansion of social rights. At the same time, are discussed the forms to the possibility of forming a third international field, in contrast to capitalist monopolies and Soviet-style communism.
\end{abstract}

Keywords: Brazilian Socialist Party; Democratic socialism; Welfare State. 


\section{LISTA DE ABREVIAÇÕES E SIGLAS}

ANL - Ação Nacional Libertadora

CEDP - Centro de Estudos e Defesa do Petróleo

CTB - Confederação dos Trabalhadores do Brasil

ED - Esquerda Democrática

MUT - Movimento de Unificação dos Trabalhadores

OIT - Organização Internacional do Trabalho

PCB - Partido Comunista Brasileiro

PDC - Partido Democrata Cristão

PR - Partido Republicano

PRP - Partido da Representação Popular

PSB - Partido Socialista Brasileiro

PSD - Partido Social Democrático

PT - Partido dos Trabalhadores

PTB - Partido Trabalhista Brasileiro

SPD - Partido Social-Democrata da Alemanha

STE - Supremo Tribunal Eleitoral

UDN - União Democrática Nacional

UNE - União Nacional dos Estudantes 


\section{SUMÁRIO}

Introdução

Capítulo I - Fatores do desenvolvimento e consolidação do socialismo democrático e do Estado de Bem-Estar Social no segundo pós-guerra

1.1 As primeiras reformas trabalhistas no Império Alemão e o comportamento dos socialistas.

1.2 A eclosão da Primeira Grande Guerra e a crise do internacionalismo socialista .... 27

1.3 Entre-guerras e segundo pós-guerra: conflito e integração.................................... 30

1.4 As definições do socialismo democrático no segundo pós-guerra ........................... 48

1.5 O início do fim do socialismo democrático no Reino Unido: do "Relatório Beveridge" ao Welfare State

Capítulo II - A trajetória dos socialistas brasileiros entre 1945 e 1965 .59

2.1 Da formação da Esquerda Democrática às eleições de 1950 62

2.2 O PSB nos anos 1950: sincretismo e flerte com o populismo. 79

2.3 Anos 1960: nacionalismo radical e revolução socialista 88

2.4 O socialismo democrático na evolução do $P S B$ 93

Capítulo III - A Esquerda Democrática na Constituinte de 1946 .95

3.1 Breve panorama político à época Constituinte .95

3.2 Uma fotografia da Esquerda Democrática à época da Constituinte 99

3.3 Expectativas socialistas no início dos trabalhos da Constituinte 109

3.4 O acerto de contas com o fascismo e com o Estado Novo. 113

3.5 Um projeto "progressivamente" socialista para o Brasil 117

3.5.1 Estado, propriedade e capital estrangeiro 118

3.5.2 O caso da Light 122

3.5.3 Nacionalização versus socialização 123

3.5.4 Planejamento econômico .... 125

3.5.5 A atuação de Gilberto Freyre .... 127

3.5.6 Presidencialismo ou parlamentarismo 128

3.5.7 Reforma agrária 130

Capítulo IV - Em busca de uma política socialista e democrática: o PSB entre 1947 e 1950

4.1 A mudança de nome. 133

4.2 Socialistas versus comunistas 136

4.3 Os socialistas e a cassação do PCB 139

4.4 Em nome do socialismo democrático 143 
4.5 O monopólio estatal da exploração do petróleo com objetivos socialistas 148

4.6 "Política sindical socialista" e o Projeto Mangabeira 153

4.7 Um socialismo democrático à deriva: o PSB na virada da década 161

Conclusão

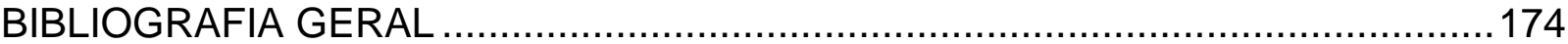

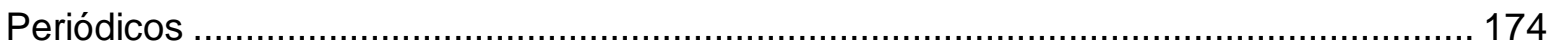

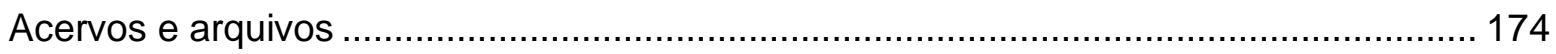

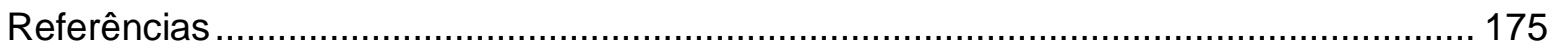

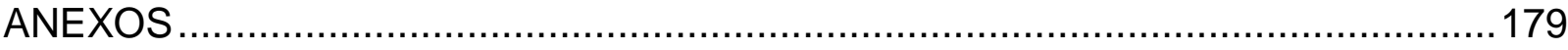

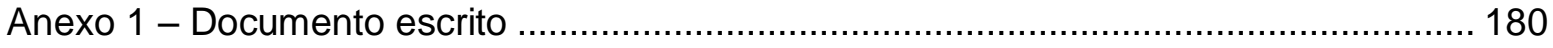

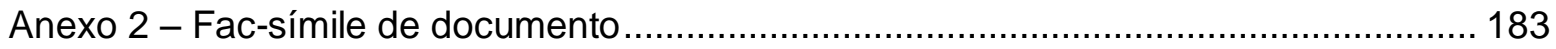

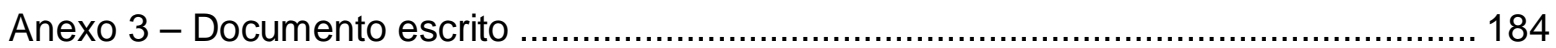

Anexo 4 - Reproduções de imagens de jornal ................................................................ 190 


\section{Introdução}

Quando a Segunda Grande Guerra chegou ao fim e teve início a reconstrução da sociedade devastada, observou-se na Europa Ocidental a consolidação de um consenso em torno da estabilidade político-econômica que envolveu reformistas e conservadores, estabelecendo as bases para o que ficou conhecido como Estado de Bem-Estar Social. Previsões de mudanças radicais foram frustradas e, ao invés disso, o Estado expandiu-se e ampliou sua intervenção na economia e na sociedade, algo que começara a ser ensaiado nas décadas precedentes. Iniciavam-se trinta anos de ininterrupto crescimento econômico que tinha, como contrapartida, um "contrato social” que estabeleceu níveis elevados de acesso a bens e serviços que satisfizessem a uma grande parcela da população. Ao passo que os comunistas eram excluídos dos pactos de reconstrução e a União Soviética era confinada à sua área de influência com o advento da Guerra Fria, os partidos social-democratas obtiveram grande apoio entre as classes assalariadas em diversos países, chegando a experiências estáveis de poder em alguns deles. Esse foi o caso notável do influente Labour Party, que se tornou no Reino Unido um pilar fundamental das reformas do Estado desde meados da década de 1940.

No Brasil, a queda do Estado Novo no final de 1945 expressou a mudança de humor decorrente da vitória sobre os regimes fascistas na Europa. Como consequência, expectativas anteriormente represadas irromperam conforme a opinião pública se posicionava diante do novo cenário, reabilitando ideias antes reprimidas ou lançando novos objetivos à política nacional. De forma irresistível, a ditadura de Getúlio Vargas foi colocada em xeque e a abertura política foi uma consequência das novas demandas e aspirações sociais.

Dentre os setores que concorreram para as mudanças, encontrava-se aquele formado por indivíduos e pequenos agrupamentos originários das lutas contra a ditadura, cujo elo comum era a atração pelas ideias socialistas. Reunidos em curto intervalo temporal durante o ano de 1945, esses elementos heterogêneos organizaram a Esquerda Democrática, mais tarde renomeada Partido Socialista Brasileiro (PSB). Procurando de início demarcar o seu diferencial ideológico em relação a outros grupos de esquerda, os socialistas brasileiros frequentemente associavam seus objetivos aos acontecimentos então em curso no Reino Unido, onde o Labour Party conquistara enorme sucesso eleitoral e iniciava a estatização de alguns setores da economia. Na perspectiva dos congêneres brasileiros do Labour Party, o trabalhismo britânico 
caminhava para a afirmação do "socialismo democrático" como alternativa a um mundo bipolar entre Estados Unidos e União Soviética.

O PSB não chegou propriamente a formular o projeto de um Estado de bem-estar social no Brasil. O conceito sequer era discutido nas formas e nos conteúdos pelos quais se consagrou posteriormente. A distância de uma realidade entendida como auspiciosa, como a que estaria em curso no Norte da Europa, seria a lacuna a ser preenchida pela ação criativa do partido. Na percepção da militância do PSB de meados dos anos 1940, o Brasil carecia de uma série de avanços democráticos preliminares que fossem pouco a pouco preparando o terreno para uma futura socialização dos meios de produção. Traçado esse objetivo, não se preconizava atentar contra as regras do jogo democrático estabelecido, mas antes a necessidade de superar diversos elementos legados pelo Estado Novo, ou ainda de épocas mais remotas, como a tutela ministerial sobre os sindicatos, a estrutura agrária brasileira e a permissividade com os monopólios econômicos. Tais elementos, considerados arcaicos e ligados a diferentes formas de autoritarismo, estariam em descompasso com a vaga histórica de um emergente socialismo democrático no mundo do pós-guerra.

No período de redemocratização do Brasil, os socialistas formularam críticas profundas a comunistas, trabalhistas e liberais, ainda que com estes últimos tenham somado forças no movimento democrático que se opôs à ditadura estadonovista. No entanto, diante do maior prestígio de seus adversários, sobretudo dos partidos que tinham maior penetração nos meios populares e sindicais, os defensores do socialismo democrático encontraram pouco espaço para proliferar. Com uma base social escassa e poucos êxitos eleitorais, o PSB foi frequentemente caracterizado como um grupo seleto de intelectuais com baixa capacidade de intervir na realidade.

Todavia, entre 1945 e 1950, a limitada sustentação social não pareceu ser suficiente para refrear o ânimo dos socialistas brasileiros quanto à viabilidade do seu projeto histórico. A intenção de persistir nesse projeto justificava-se, entre outros motivos, pelo fato de o PSB entender a si mesmo como parte dos esforços socializantes presentes em diversas partes do mundo, entendidos como um programa para barrar as tendências vistas como autoritárias e inexoráveis do comunismo e do capitalismo. Por essa perspectiva, ambos os sistemas partilhariam o fortalecimento crescente do Estado como forma de habilitar as classes dominantes a acelerar o processo de concentração de riquezas e a subjugação das classes assalariadas. Nesse cenário, o socialismo democrático seria um "terceiro campo", não disposto a fomentar a tomada do Estado pelo alto, para em seguida introduzir o alegado "capitalismo de 
Estado"; e, tampouco, a permitir a dominância dos monopólios privados sobre a vida da maioria da população. Para os socialistas brasileiros, ambos os casos produziriam resultados análogos, que liquidariam as formas democráticas de convívio social e, com estas, os direitos sociais conquistados pelos trabalhadores.

O PSB esteve longe de constituir um agrupamento homogêneo. Durante toda a sua existência, diferentes personalidades entraram em conflito em sua atuação partidária, e dependendo do debate travado internamente, as discussões podiam degenerar em desintegração do partido. Contudo, desde o seu surgimento, assumiu-se o objetivo estratégico de socializar os meios de produção pela via das regras democráticas estabelecidas, o que foi, dali em diante, reiterado por todo o conjunto da militância. Pretendia-se, com esse objetivo, angariar adeptos principalmente nas classes assalariadas, modificar a política dominante nos meios sindicais e, por conseguinte, constituir um amplo eleitorado para impulsionar as mudanças na economia, no sentido de tornar a população uma livre gestora dos meios de produção.

Com esses objetivos em mente, não faltaram nos círculos do PSB referências aos trabalhistas britânicos como exemplo bem-sucedido de avanços democráticos na direção de uma economia planejada e participativa. Entre 1945 e 1950, essas referências à experiência britânica foram sistemáticas, e se não serviram necessariamente para armar a militância socialista brasileira de elementos teórico-políticos para vencer os entraves que se colocavam diante de seu projeto, parecem ao menos ter contribuído para exercer alguma coesão ideológica do seu partido.

Nesta dissertação buscamos analisar de que forma a militância do PSB, inspirada por uma visão de mundo com base no ideário socialista democrático, absorveu o fluxo de ideias produzidas internacionalmente e, ao mesmo tempo, construiu propostas próprias para intervir na realidade brasileira com o objetivo de alcançar a meta de economia socializada com exercício pleno de direitos democráticos. Portanto, não se trata de identificar a mera transposição, pelo partido, de modelos políticos formulados em outros lugares, mas, sim, de investigar a forma de absorção e reformulação de ideias de circulação internacional, bem como resgatar os problemas resultantes da tentativa de construir uma difícil unidade de pensamento socialista democrático na conjuntura brasileira do pós-guerra.

A evidenciação de um movimento transnacional de ideias norteia as argumentações desta dissertação, problematizando as contribuições do PSB de modo a lançar luz sobre um conjunto de aspirações pouco investigadas pela historiografia sobre o período. Nosso recorte 
de tempo vai dos estertores do Estado Novo ao final do governo do general Eurico Gaspar Dutra. Durante esse período, o PSB fundamentava suas teses e buscava - mais que em qualquer outro momento - diferenciar-se dos partidos concorrentes, em um processo marcado simultaneamente por uma série de conflitos internos. É também um tempo em que os socialistas não tiveram experiências de gestão governamental e obtiveram a mais baixa representação legislativa de sua trajetória, mas que, ao mesmo tempo, acumularam uma produção teórica extensa, registrada nos dois principais veículos da imprensa socialista: os jornais Folha Socialista e Vanguarda Socialista. Ao lado dos documentos do PSB e da imprensa nacional da época, essas são as fontes principais de análise deste trabalho.

No capítulo primeiro, apresentamos eventos e fatores políticos, econômicos e ideológicos que, entre os séculos XIX e XX, levaram a transformações profundas na sociedade e na social-democracia europeia. O objetivo principal do capítulo é demarcar tanto o caminho que levou à afirmação do socialismo democrático, da década de 1940, quanto a natureza dos anseios sociais aos quais esse ideário buscou corresponder. Com isso, pretende-se oferecer um panorama geral do ambiente que possibilitou o surgimento do Estado de Bem-Estar Social europeu, com o qual o PSB buscou sintonizar-se nos primeiros anos de existência do partido.

O capítulo segundo aborda toda a trajetória do PSB (1945-1965) a fim de explicitar mudanças de rumo do partido como resposta ou sujeição às novas demandas que surgiram na sociedade brasileira. O enfoque principal está no surgimento do partido, ainda com o nome de Esquerda Democrática, e a construção do seu ideário em contraste com outros atores políticos. No entanto, ao abordar a atuação socialista em um prazo maior de duração, com o auxílio da historiografia sobre o PSB, a intenção é distinguir com mais clareza as especificidades do imediato pós-guerra que é objeto dessa dissertação, avaliando, ao final, a originalidade do socialismo democrático na sua versão brasileira, e o peso exercido sobre ele pelas ideias circundantes do Estado de Bem-Estar Social.

O objeto do capítulo terceiro é a Assembleia Constituinte de 1946, momento em que a pequena bancada socialista dispôs de um espaço cercado de atenção especial para tornar públicas as suas propostas para a sociedade brasileira. Além de ser o ano da elaboração da nova Carta Magna, 1946 também se caracterizou pelo início do ataque desencadeado pelo governo Dutra aos sindicatos e aos comunistas. Enquanto discutiam o reestabelecimento de normas democráticas e a introdução de novos preceitos econômicos na vida nacional, os socialistas não estiveram indiferentes ao que se passava nas ruas. Assim, os eventos circunscritos àquele ano constituem-se em um momento privilegiado para o estudo das concepções socialistas no Brasil. 
No capítulo quarto fazemos uma análise dos temas que foram mais importantes na agenda dos socialistas entre 1947 e 1950: a luta pela autonomia sindical, o projeto de reforma da legislação trabalhista formulada pelo partido, o monopólio estatal da exploração do petróleo e, permeando tudo isso, a definição de uma política socialista democrática que, em sintonia com a conjuntura mundial, conferisse sentido amplo às reformas defendidas pelo PSB.

Por fim, concluímos com uma análise do possível lugar ocupado pelas propostas dos socialistas brasileiros entre os anos de 1945 e 1950, em um contexto mais amplo de afirmação do Estado de Bem-Estar Social na Europa. Sugere-se que, ao lado da problemática da manutenção e expansão dos direitos sociais em meio à consolidação do Estado capitalista, alguns pressupostos teóricos do PSB atravessaram o tempo, dando relevância às leituras originais produzidas pelo partido sobre o tema. 


\section{Capítulo I - Fatores do desenvolvimento e consolidação do socialismo democrático e do Estado de Bem-Estar Social no segundo pós-guerra}

No imediato pós-Segunda Grande Guerra, muitas das reivindicações dos socialistas europeus desde a fundação da Segunda Internacional - sufrágio universal, cidadania plena às mulheres, jornada de trabalho de oito horas, entre outros - já haviam sido conquistadas ou estavam em vias de serem implementadas. Os partidos social-democratas europeus, como os do Reino Unido e Escandinávia, assumiram seu lugar entre as principais forças políticas do velho continente, metamorfoseando-se em partidos de governo com o decisivo suporte da classe média e, pela primeira vez, com expressivo apoio da maioria da classe operária. O sucesso dessa guinada expressava o humor daqueles tempos: sentimentos solidários após a luta contra um inimigo comum, reconhecimento do fracasso dos conservadores em deter a ascensão do fascismo, vivas memórias da depressão dos anos 1930 e a sensação da necessidade de profundas mudanças. ${ }^{1}$

No Reino Unido, o Labour Party encarnava um dos mais inspiradores projetos reformistas no período, sobretudo devido às expectativas em torno de seu gabinete montado após a vitória sobre os conservadores nas eleições gerais de $1945 .^{2}$ Aos olhos de muitos, abriase um caminho sem precedentes para a sedimentação de uma ordem de justiça social em bases democráticas. Para um eleitorado exausto pelos sacrifícios de guerra, o partido apresentava-se como o mais capacitado a promover as mudanças almejadas, ainda que o conteúdo destas não estivesse muito claro àquela altura. ${ }^{3}$

Os trabalhistas britânicos não postulavam atacar as estruturas capitalistas, e sim uma ampliação do direito à cidadania - outrora o grito de guerra da tradição liberal-democrática complementada por novos direitos socioeconômicos. Esperava-se que, a fim de tornar esses

\footnotetext{
${ }^{1}$ SASSOON, Donald. One hundred years of socialism: the West European Left in the twentieth century. London: I.B. Tauris, 2010, p. 117-122.

2 As eleições ocorreram dois meses após a capitulação da Alemanha nazista. Liderado por Clement Atttlee, o Labour Party - ou Partido Trabalhista - superou os conservadores por uma diferença de pouco mais de $10 \%$ dos votos válidos. A derrota do Tory - ou Partido Conservador - revelou-se humilhante, uma vez que seu líder, Winston Churchill, esperava contar com o enorme prestígio pessoal acumulado pela vitória sobre o nazismo.

${ }^{3}$ De modo geral, a social-democracia chocou-se, em outros países europeus, com os limites impostos por máquinas públicas pouco confiáveis quanto à sua "eficácia democrática". Persistiam burocracias estatais ainda simpáticas a forças antidemocráticas, sistemas meritocráticos pouco permeáveis a membros não pertencentes às classes altas e um disseminado clientelismo que orientava o acesso aos postos públicos. No caso ainda da Alemanha Ocidental, as instituições estatais necessitavam ser inteiramente reconstruídas. Ibidem, p. 124-125.
} 
direitos acessíveis a todos, fossem estabelecidas as condições econômicas para o crescimento e a prosperidade material. Uma vez que se entendia que o mercado não era capaz de proporcionar tais resultados por si próprio, seria necessário um Estado que interviesse na economia de forma racional e efetiva. ${ }^{4}$

Pode-se dizer que os trabalhistas britânicos lograram capitalizar anseios acumulados durante toda a primeira metade do século XX, em meio à crise política, econômica e militar que se abateu sobre a Europa e que colocava em questão os fundamentos político-econômicos do liberalismo. Contudo, no decorrer desse período, a resposta à crise veio sob a forma de importantes mudanças institucionais que criaram as condições para um Estado capitalista mais fortalecido. É somente com essas transformações que se pode pensar o surgimento de um Estado de Bem-Estar Social a partir da segunda metade da década de 1940. A ideia de um Estado protetor consubstanciou-se em projetos que pretendiam superar a ineficácia das soluções assistencialistas, incapazes de atenuar o confronto entre os grandes grupos econômicos e a agitação social, sendo esta entendida como um subproduto tanto da ação organizada dos sindicatos quanto do pauperismo de grande parte da população britânica. ${ }^{5}$

O prenúncio dos novos tempos inspirou velhos e novos socialistas no Brasil, país que jamais teve partidos ocupando algum lugar relevante no movimento socialista internacional. Conforme veremos nos capítulos seguintes, imediatamente após o fim do Estado Novo, os socialistas brasileiros buscariam formas mais ou menos inovadoras para trilhar um caminho inspirado pelos novos influxos do chamado socialismo democrático. O presente capítulo esboça alguns fatos históricos determinantes da construção de uma genérica ideologia socialista democrática que desembarcou no Brasil a partir de meados da década de 1940. Ao final, apresentaremos uma noção dos amálgamas que transformaram tradições e que poderiam ter fornecido novos elementos para a atuação de um então jovem Partido Socialista Brasileiro.

\subsection{As primeiras reformas trabalhistas no Império Alemão e o comportamento dos socialistas}

A ideia de que o Estado devesse prover um certo nível de bem-estar social origina-se de um debate muito anterior àquele dos anos 1940, localizado mais precisamente no período que

\footnotetext{
${ }^{4}$ Ibidem, p. 123-124.

${ }^{5}$ OFFE, Claus. Problemas estruturais do Estado capitalista. Tradução de Bárbara Freitag. Rio de Janeiro: Tempo Brasileiro, 1984 (Cap. II).
} 
se seguiu à consolidação do poder de Otto von Bismarck na Alemanha unificada. As medidas adotadas àquela altura, no entanto, não resultaram propriamente em um novo modelo de Estado, mas em mudanças pontuais em termos de seguridade social que foram se efetivando a partir da década de 1880.

À derrota do movimento liberal alemão de 1848 seguiu-se um longo período de modernização que deixou os setores do conservadorismo alemão diante de novos problemas originados do desenvolvimento rápido e tardio da grande indústria, tais como o pauperismo e a agitação social. No último quartel do século XIX, enquanto a Alemanha vivia um crescimento econômico sem precedentes, os socialistas alemães enfrentavam a hostilidade de praticamente todos os partidos políticos domésticos. Mesmo a pequena-burguesia representada pelo Partido Radical, de orientação progressista-liberal e laicista, e que vivia achatada entre o latifúndio e a grande indústria, tornou-se uma ferrenha opositora das teorias e práticas do Partido SocialDemocrata da Alemanha (SPD). ${ }^{6}$

As hostilidades tinham um claro motivo: a industrialização avançava transformando as condições de vida de um crescente operariado que, paralelamente, passava por um processo de radicalização política. Mesmo as famosas Leis Antissocialistas, que perduraram entre 1878 e 1890, foram incapazes de frear a crescente influência popular das ideias do SPD, chamadas de patológicas por Bismarck, o poderoso chanceler do Império Alemão, para quem o socialismo, ao ameaçar o Estado e a sociedade existentes, deveria ser erradicado por leis de exceção. Apesar de milhares de prisões, do fechamento de sua imprensa e da proibição de organização, o trabalho clandestino dos socialistas prosperou. ${ }^{7}$

Diante de um cenário sócio-político em intensa transformação, Bismarck, representante máximo dos junkers, a nobreza fundiária alemã, previa soluções que pudessem conter tanto os anseios do liberalismo conservador da nova burguesia financeira quanto a pregação de uma social-democracia, cuja influência nos meios operários vivia uma formidável ascensão. Adotando sempre um paternalismo de coloração cristã, Bismarck chegou a declarar que a insegurança social do trabalhador era a causa real de essa classe se tornar um perigo ao Estado. O chanceler defendia a necessidade de atrair para a esfera do poder público adeptos e simpatizantes oriundos da classe trabalhadora, de modo a suplantar o polo de atração socialista.

\footnotetext{
${ }^{6}$ RAMOS-OLIVEIRA, Antonio. Historia social y política de Alemania. Vol. 1. $3^{\mathrm{a} e d .}$ Ciudad de México: Fondo de Cultura Económica, 1995, p. 262.

${ }^{7}$ Ibidem, p. 262-266.
} 
Após uma sequência de batalhas no parlamento, encarando a oposição bifronte dos seus adversários, Bismarck conseguiu a aprovação de importantes medidas de assistência social, como o auxílio em caso de doença e acidente de trabalho e a aposentadoria por tempo de serviço e por invalidez. ${ }^{8}$

Ainda que tivesse cedido em diversos pontos às exclamações da grande burguesia representada no Parlamento, que chegava a acusá-lo de socialista, Bismarck fez aprovar leis cujo conteúdo, ao menos em termos práticos, não se baseava em qualquer experimento prévio. Em grande parte, as medidas resultavam das pressões oriundas da ascensão do movimento sindical e socialista. Em discurso no Reichstag, em novembro de 1884, ao fazer um balanço das reformas então em curso, o chanceler declarou: "se não houvesse um partido socialista e nem tanta gente assustada por esse partido, não existiriam os poucos avanços que temos realizado no domínio das reformas sociais",

Segundo Henry Sigerist, pelo menos até o fim da década de 1880, o SPD, que não se declarava contrário a políticas de seguridade social em si, comportou-se como feroz opositor das propostas de Bismarck, alegando que elas poupavam as classes proprietárias dos ônus assumidos pelo Estado - onerando, em consequência, a riqueza produzida pelos próprios trabalhadores. ${ }^{10}$ No entanto, as reformas de Bismarck tiveram o efeito de dividir os próprios socialistas, como quando dois deputados do SPD tentaram convencer o chanceler a suspender as leis de exceção contra seu partido, em troca do reconhecimento da importância das novas políticas sociais. ${ }^{11}$ À frente da direção do periódico Der Sozialdemokrat, distribuído clandestinamente, Eduard Bernstein atacou duramente seus dois colegas, chamando-os de oportunistas. Para encerrar a questão, em março de 1883, 60 delegados socialistas alemães reuniram-se em Copenhague, para definir a postura do partido diante da nova realidade, aberta pelo reformismo bismarckiano. Ficou decidido que as "supostas" reformas sociais não poderiam satisfazer aos interesses dos socialistas, a quem caberia o dever de manter suas reivindicações históricas e permanecer fieis aos seus princípios. ${ }^{12}$

\footnotetext{
${ }^{8}$ SIGERIST, Henry. From Bismarck to Beveridge: developments and trends. Journal of Public Health Policy. vol. 20, n. 4, 1943, p. 479-490.

${ }^{9}$ RAMOS-OLIVEIRA, op. cit., p. 266.

${ }^{10}$ SIGERIST, op. cit., p. 485.

${ }^{11}$ Embora o SPD estivesse clandestino, não havia impedimento formal a candidaturas de deputados socialistas ao Reichstag.

${ }^{12}$ RAMOS-OLIVEIRA, op. cit., p. 268.
} 
Duas semanas antes do encontro de Copenhague, Karl Marx morreu em Londres. Simbolicamente, a coincidência dos acontecimentos se revestiu de uma importância que não deve passar despercebida. A morte do principal teórico do socialismo ocorreu no momento em que frente a suas formulações teóricas, que se propuseram construir uma autoconsciência proletária, colocaram-se novos e cruciais problemas para o movimento operário. Para onde rumaria o socialismo e o que afinal ele representaria seriam questões que não tardariam a surgir, produzindo divergências não mais passíveis de serem contornadas sem que fossem provocadas importantes cisões partidárias (como veremos no próximo item).

Segundo Sigerist, o objetivo de conter o impulso revolucionário dos social-democratas foi atingido com sucesso pelas reformas, o que por outro lado não impediu o crescimento vertiginoso do SPD no final do século XIX - um sinal de que a insatisfação de um imenso contingente de trabalhadores poderia ser amenizada pelo governo, mas não eliminada totalmente. Diante do temor dos trabalhadores de perderem os direitos conquistados, e da expectativa de ampliá-los, o SPD paulatinamente incorporou a disputa em torno das leis de seguridade social como algo central em sua agenda, distanciando-se de sua oposição incondicional adotada inicialmente. ${ }^{13}$

O caso inaugural alemão ilustra um fenômeno que se espalharia pelo resto da Europa e que continuaria a desafiar os partidos socialistas: havia um novo conjunto de reformas em marcha e os socialistas não podiam se deixar confundir com apologistas da volta ao passado. Esse dilema, no entanto, não lhes privaria de denunciar tal modelo como insuficiente ou mesmo ilusório, pois seu objetivo estratégico continuava sendo a abolição definitiva da exploração capitalista. A questão principal para os socialistas, portanto, era que as reformas não diziam respeito somente à discussão em torno deste ou daquele ponto, mas de como se portar em uma arena de disputa política que, a cada vez, mais atraía a classe trabalhadora para esferas de decisões em que os herdeiros de Marx não se sentiam nada confortáveis. ${ }^{14}$

Na data simbólica de 14 de julho de 1889, exatos cem anos passados da Tomada da Bastilha, 407 delegados de vinte países se reuniram em Paris, no congresso que fundaria a II Internacional Socialista. Os participantes reafirmaram as reivindicações históricas do

\footnotetext{
${ }^{13}$ SIGERIST, op. cit., p. 491-493.

${ }^{14}$ Segundo dados levantados por George Steinmetz, durante as décadas de 1870 e 1880, o SPD raramente intervia nos debates nacionais no Reichstag, preferindo, ao invés disso, priorizar o trabalho político extraparlamentar. STEINMETZ, George. "The local welfare state: two strategies for social domination in urban Imperial Germany”. American Sociological Review, v. 55, n. 6, dez. 1990, p. 891-911.
} 
movimento socialista internacional, como a jornada de trabalho de oito horas e repouso de 36 horas semanais, além da exigência de um sistema internacional de proteção ao trabalho, sobretudo de mulheres e crianças. Uma polêmica, porém, ocuparia parte dos trabalhos dos congressistas: a questão da relação dos socialistas com o parlamento. Um militante anarquista italiano, que vivia exilado em Londres e integrava a delegação inglesa da Liga Socialista, sintetizou a certa altura do congresso a preocupação de boa parte dos delegados, ao considerar que

...é perigoso fomentar entre as massas a grande superstição do século, que consiste em pretender resolver os grandes problemas sociais através das urnas e das decisões parlamentares; [...] é necessário, ao contrário, minar e destruir os fetiches da legislação e dos legisladores; [...] a legislação do trabalho oferecida oficialmente pelos governos tem apenas um objetivo, que é o de reabilitar aos olhos das massas o parlamentarismo, que passa a ser totalmente desacreditado, e prolongar a sua vida agonizante. ${ }^{15}$

Ao considerar essa posição, é possível perceber que as novidades introduzidas pelas legislações trabalhistas tomavam um lugar importante para a estratégia dos partidos socialistas. Seja para refutá-las, como armadilhas de dominação da classe burguesa, seja para superá-las incorporando-as, era impossível ignorar as muitas variáveis que a nova realidade impunha a atuação partidária junto aos assalariados.

Em outubro de 1891, o SPD realizou seu emblemático Congresso de Erfurt, marcando uma virada histórica na orientação oficial do partido após o reformismo parlamentar ter sido ratificado. O programa final aprovado não concebeu o abandono do conceito de revolução, permitindo que a social-democracia continuasse a representar a única formidável força política que advogava a superação do regime capitalista. Mas tal conceito tornava-se cada vez mais indefinido, pois, por força da liderança de Eduard Bernstein, August Bebel e Karl Kautsky, aprofundou-se a ideia de que os socialistas deveriam atuar nas instituições políticas existentes, como o Parlamento. Entendia-se que, simultaneamente ao fortalecimento dos monopólios econômicos e o incremento de produtividade, aumentava o contingente dos despossuídos. $\mathrm{O}$ processo atingiria não só a classe operária oriunda do trabalho artesanal ou do campesinato, mas também a classe média e a pequena burguesia, a ponto de a sociedade moderna adquirir uma característica básica em todos os países industriais: a constituição de dois campos hostis com interesses inconciliáveis. Sob essa perspectiva, a luta contra a miséria, a opressão, a degradação e a exploração decorrentes da contradição fundamental do capital deveria assumir

\footnotetext{
${ }^{15}$ MERLiNO, Francesco S. Apud SOCIALIST LEAGUE. The Paris Congress: a delegate's report. Commonweal, 10 ago. 1889. Disponível em: 〈https://www.marxists.org/archive/kitz/congress.htm>
} 
um caráter de luta por avanços dos direitos políticos e sociais. Sem que a classe mais numerosa obtivesse correspondente poder político, suas reivindicações econômicas e, em última instância, a socialização dos meios de produção seriam objetivos inalcançáveis. Consequente com essas conclusões, algumas das principais bandeiras do Programa de Erfurt conclamavam os socialistas a lutar pelo sufrágio universal e por uma série de aperfeiçoamentos da legislação eleitoral. No tocante às reivindicações trabalhistas, o SPD fez valer seu papel de partido "líder" da esquerda europeia, ao reiterar os pontos firmados no Congresso de Paris e dar ênfase ao caráter internacionalista das proposições. Quanto à legislação de proteção social vigente no Império Alemão, exigia-se que o sistema de seguridade social passasse ao controle exclusivo dos trabalhadores. ${ }^{16}$

Ao adotar decisivamente a via eleitoral e reformista, o Programa de Erfurt consentia a necessidade de preservar o sistema de proteção social fundado pelos inimigos históricos dos social-democratas da Alemanha. Apontando, no entanto, para a necessidade de socializar esse sistema, transferindo-o para a administração direta dos trabalhadores, os socialistas teriam mantido o conteúdo transformador da obra a que se propunham. Pode-se perguntar em que medida as reformas iniciadas por Bismarck tiveram papel nas mudanças do ideário socialista na passagem do século XIX para o XX. Por outro lado, seria mais seguro admitir que a crença fatalista de que o desenvolvimento das contradições do capitalismo solaparia o regime burguês de dominação deu segurança aos dirigentes socialistas quanto à irrevogabilidade das reformas. Afinal, diferentemente do que poderiam supor as alas revolucionárias hostis aos compromissos com as instituições do Estado alemão, o sistema de proteção social poderia ser visto como expressão dos sinais da derrocada capitalista.

Aparentemente, as mudanças abruptas na conjuntura política alemã, ocorridas no ano anterior à realização do Congresso de Erfurt, contribuíram para o deslanchar das novas diretrizes programáticas do SPD. Em março de 1890, Bismarck demitiu-se do posto de chanceler após perder a legitimidade que lhe restava para conduzir o Reich. Desde 1888 havia um novo imperador no trono, Guilherme II, a quem interessava obter maior controle pessoal sobre a política interna e externa da Alemanha. Assim como Bismarck, Guilherme II também se propunha a combater os socialistas, mas para isso previa métodos diferentes daqueles empregados até então pelo chanceler de ferro. O imperador adotou uma postura paternalista em relação à classe trabalhadora, como parte de um mesmo projeto conservador, antiliberal,

16 Cf. The Erfurt Program, 1891. Disponível em: <https://www.marxists.org/history/international/socialdemocracy/1891/erfurt-program.htm> 
militarista e imperialista que caracterizou o seu reinado. Acreditando poder dirimir as diferenças entre o poder central e os trabalhadores, Guilherme II suspendeu as leis de exceção contra os socialistas em janeiro de 1890, buscando sinalizar que, para derrotar a esquerda, tais expedientes não eram mais necessários. ${ }^{17}$ Como Bismarck, Guilherme II falhou em suas previsões: apenas um mês depois de sair da clandestinidade, o SPD registrou uma espetacular votação nas eleições legislativas, com quase 1 milhão e meio de votos, tornando-se a maior bancada no Reichstag - ainda que se mantivesse na oposição à coalizão vencedora. Com um leve decréscimo em 1907, o aumento da representação no Reichstag se manteria de forma consistente nas eleições seguintes até que eclodisse a Primeira Grande Guerra, ao final da qual os socialistas finalmente passariam a compor o governo alemão.

Guilherme II foi também protagonista das primeiras iniciativas da diplomacia internacional de exame da situação dos trabalhadores industriais e estabelecimento de medidas regulatórias. Na verdade, a iniciativa coube ao governo suíço que, desde 1881, buscava sem sucesso a cooperação dos governos vizinhos para a edição de normas internacionais do trabalho. Quando em 1889 os suíços endereçaram uma nova circular sugerindo a convocação de uma conferência para tratar do tema, Guilherme II, líder de uma ascendente potência mundial, não teve dificuldades em tomar as rédeas da situação e assumir a tarefa de organizar o encontro. Como vimos, ao jovem imperador interessava reconciliar o Estado com o operariado. Além disso, o Congresso dos Trabalhadores em Paris não passou despercebido, suscitando alguma preocupação aos diversos governos europeus. Como as condições de vida da classe trabalhadora seguiam causando agitação social e política, e como na Alemanha e na Inglaterra já se haviam introduzido leis de proteção social - e a França rumava na mesma direção - criava-se um consenso entre as elites industriais europeias de que não era possível assumir unilateralmente as implicações do aumento dos custos de produção em relação a competidores não submetidos a regulamentações trabalhistas. ${ }^{18}$

Em março de 1890, delegações de treze Estados industriais europeus reuniram-se em Berlim para a Conferência Internacional do Trabalho nas Fábricas e Minas. ${ }^{19}$ As discussões

\footnotetext{
${ }^{17}$ RAMOS-OLIVEIRA, op. cit., p. 270-271.

${ }^{18}$ BUTLER, Geoffrey; MACCOBY, Simon. The development of international law. New Jersey: The Lawbook Exchange, 2003, p. 496-498.

${ }^{19}$ Estiveram presentes as delegações da Alemanha, Áustria-Hungria, Bélgica, Dinamarca, França, Grã-Bretanha, Itália, Luxemburgo, Holanda, Portugal, Suécia, Noruega e Suíça. A Rússia recusou o convite. Com uma população esmagadoramente camponesa e uma economia predominantemente rural, é discutível em que medida a Rússia poderia ser considerada um Estado industrial em 1890.
} 
confluíram para apenas esboçar recomendações que pudessem servir ao conjunto de governos nacionais comprometidos com os debates. Era um primeiro experimento, sem poderes de definir normas que, caso descumpridas, implicassem qualquer tipo de sanção. Algo nessa direção só entraria em vigor a partir da assinatura do Tratado de Versalhes, em 1919, quando juntamente à Liga das Nações, criou-se a Organização Internacional do Trabalho (OIT). Sintomaticamente, na ocasião da abertura do Congresso em Berlim, o semanário conservador inglês The Spectator assumiu um tom pessimista em relação ao encontro, apostando que dele resultaria apenas uma declaração acadêmica, ainda que se pudesse atingir resultados satisfatórios caso as proposições fossem realmente aplicadas. ${ }^{20}$

O protocolo final da OIT continha pontos referentes ao emprego de mulheres, crianças e adolescentes de acordo com o tipo de trabalho - além de uma série de restrições aos jovens, previu-se, por exemplo, o alcance de certo nível educacional como um pré-requisito desejável -; descanso dominical; restrições de idade e gênero para o trabalho dos mineiros, cuja saúde e segurança deveriam ser supervisionadas pelo Estado; desenvolvimento progressivo de redes de proteção em casos de doenças e acidentes e de auxílio à velhice e morte; compromissos entre patrões e empregados para evitar greves e garantir o respeito ao arbítrio quando as negociações diretas não prosperassem; e, finalmente, que a execução dessas medidas deveria ser fiscalizada em cada Estado por agentes governamentais, incumbidos de produzir relatórios acerca das condições de trabalho e intercambiá-las entre os governos. ${ }^{21}$

Em geral, e a exemplo dos socialistas, os partidos liberais e conservadores também tinham motivos para se sentirem desconfortáveis diante do tema das reformas, sendo levados a trair suas mais íntimas convicções ao ceder a demandas e compromissos impostos pelo advento de novas tendências sociais. O estilo de reformismo iniciado por Bismarck tendia a se reproduzir onde quer que rondasse o espectro da agitação social. Adotavam-no as mais variadas forças que, uma vez no poder, antecipavam-se a seus oponentes com projetos os mais adequados possíveis a seus próprios interesses. ${ }^{22}$ As mudanças pontuais introduzidas por esse tipo de reformismo vigorariam até os anos 1940, quando uma nova conjuntura histórica levaria um conjunto de economias ocidentais a um novo nível de reformas, as quais finalmente

\footnotetext{
${ }^{20}$ The International Labour Conference met at Berlin on Saturday. The Spectator, 22.03.1890, p. 2.

${ }^{21}$ BUTLER; MACCOBY, op. cit., p. 498-499.

${ }^{22} \mathrm{Na}$ Itália, os liberais liderados por Giovanni Giolitti, bem como o emergente catolicismo político; na França da Terceira República, os liberais do Partido Radical; na Grã-Bretanha, tanto conservadores quanto liberais; na Áustria, os social-cristãos antissemitas liderados por Karl Lüger; e na Holanda, os novos partidos confessionais em aliança com os liberais. Cf. SASSOON, op. cit., p. 20.
} 
consubstanciariam o que se conhece por Welfare State. Antes disso, mesmo quando formou o primeiro governo socialista do mundo, em 1920, o Partido Social-Democrata Sueco não conseguira implementar nada além de medidas análogas às de Bismarck - moradias públicas, auxílio-desemprego, salário-mínimo, imposto sobre a renda e pensão para os idosos - enquanto que o respeito pelos ditames da disciplina monetária permaneceu intacto. ${ }^{23}$

Terminado o ciclo virtuoso do crescimento econômico nos anos de calmaria internacional, que havia iniciado a partir de meados da década de 1890, com maior nitidez a Europa revelou ser um barril de pólvora e, a partir de 1914, a eclosão da Primeira Guerra lançaria pelos ares tanto o frágil equilíbrio de poder entre as potências quanto o internacionalismo operário.

\subsection{A eclosão da Primeira Grande Guerra e a crise do internacionalismo socialista}

A Primeira Internacional Socialista (ou Associação Internacional dos Trabalhadores), ativa em maior ou menor grau entre 1864 e 1877, tinha como meta inicial coordenar o trabalho dos socialistas atuantes nos marcos específicos de cada realidade nacional. Contudo, como logo ficou claro às direções, discutir e deliberar sobre a posição dos partidos de esquerda frente a política externa dos Estados nacionais passou a ser uma questão-chave para o internacionalismo operário. Sob a inspiração de Marx e Engels, cujas elaborações teóricas desbancaram a concorrência de ideias taxadas como utópicas, o tema da guerra foi encarado não de acordo com as motivações circunstanciais de Estados eventualmente beligerantes, mas segundo os objetivos finais do proletariado. Tal entendimento significa dizer que uma guerra ou um objetivo nacional poderia ser entendido como "justo", desde que pusesse o proletariado em melhores condições de atuar de forma autônoma. ${ }^{24}$

A partir dessa concepção, a aversão do movimento socialista contra o Império Russo, progressivamente fortalecida desde 1848 e compartilhada também por liberais, seria facilmente assumida de forma categórica e duradoura pelos discípulos do marxismo. Havia pouca dúvida

\footnotetext{
${ }^{23}$ PRZEWORSKI, Adam; WALLESTEIN, Michael. O capitalismo democrático na encruzilhada. Novos Rumos. n. 22 , out. 1988 , p. 32 . Por primeiro governo socialista entende-se aqui um governo socialista "puro sangue". Após as eleições gerais alemãs de 1919, as primeiras da República de Weimar, o SPD não se afirmou como força política absolutamente majoritária, submetendo-se assim a coalizões com partidos de centro (ou de centro-direita, dependendo da análise).

24 REBERIOUX, Madeleine. O debate sobre a guerra. In: HOBSBAWM, Eric (Org.). História do marxismo: o marxismo na época da Segunda Internacional. Tradução de Leandro Konder. v. 4. 2.ed. Rio de Janeiro: Paz e Terra, 1986, p. 281-2 e 229-30.
} 
de que o Czar seguia representando a imagem escancarada da contrarrevolução, do gendarme da reação europeia. ${ }^{25}$ Mas quando do estouro da Guerra Franco-Prussiana (1870-1871), ao passarem pela primeira prova do internacionalismo, os deputados do SPD, sob a liderança de August Bebel e Wilhelm Liebknecht, votaram contra os créditos de guerra solicitados ao Reichstag por Bismarck - ato que os levou à prisão por condenação de traição - e ao reconhecimento de heroísmo por seus seguidores. Da mesma forma procederam os representantes socialistas no parlamento francês, em comum acordo que os objetivos beligerantes eram contrários aos interesses dos trabalhadores. ${ }^{26}$

Passados os reveses sentidos pelo movimento operário internacional na sequência da derrota da Comuna de Paris (1871), um novo cenário se apresentaria no final da década de 1880. Não só na Alemanha, onde - como vimos - o SPD já havia dado grandes demonstrações força, mas por toda a Europa, os socialistas apareceram em peso nos parlamentos - uma realidade que receberia novo estímulo com a eclosão da Revolução Russa de 1905. Na esfera extraparlamentar, diferentes formas de manifestação operária - políticas, culturais - geralmente associavam-se a um partido socialista, social-democrata ou trabalhista que figuravam quase que como voz política uníssona do operariado de um determinado país, deixando pouca margem para organizações de esquerda concorrentes. ${ }^{27}$

A partir da criação da Segunda Internacional (ou Internacional Socialista) no Congresso de Paris, em 1889, ao qual já nos referimos, as definições estratégicas do movimento operário internacional passaram a vincular a revolução socialista à causa da paz. Em um contexto de prosperidade econômica e certos avanços democráticos, já então os partidos socialistas se enraizavam no quadro político e cultural de seus respectivos países, tomando parte em diversas aspectos do desenvolvimento da civilização moderna. Como resultado, à paz subentendia-se um estado de coisas propício à atividade socialista e, consequentemente, à reorganização da sociedade. ${ }^{28}$ Os socialistas sentiam-se comprometidos com o progresso, ou ainda, como legítimos representantes da marcha da razão, da educação e da tecnologia. Contudo, os socialistas preferiam manter distância dos governos e das políticas da classe dominante, até que

\footnotetext{
${ }^{25}$ Ibidem, p. 284.

${ }^{26}$ Ibidem, p. 289; RAMOS-OLIVEIRA, op. cit., p. 251-2; ROTH, Guenther. The Social Democrats in Imperial Germany: a study in working-class isolation and national integration. New Jersey: Bedminster Press, 1963, p.53.

${ }^{27}$ HOBSBWAM, Eric. A era dos impérios 1875-1914. Tradução de Sieni Maria Campos e Yolanda Steidel de Toledo. 13.ed. Rio de Janeiro: Paz e Terra, 2009, p. 208-211.
}

${ }^{28}$ REBERIOUX, op. cit., p. 290. 
seu próprio movimento estivesse em condições de iniciar as transformações da sociedade. Partidos socialistas e trabalhadores sob sua esfera acreditavam depender somente da sua própria ação para transformar a sociedade. ${ }^{29}$

Se no âmbito do internacionalismo operário os sucessivos congressos da Segunda Internacional reafirmavam a entidade como o "Partido Socialista Internacional", ou como o "verdadeiro e único partido da paz", a verdade era que a estrutura organizacional de seus partidos-membros já apontava em sentido oposto. As especificidades da luta política em cada nação reconfiguravam os partidos, que se encontravam cada vez mais inseridos na vida parlamentar. Aprofundava esse quadro o fato de que, diante da escalada do militarismo e do expansionismo das potências europeias, do Japão e dos Estados Unidos, e das tensões impostas pelas disputas inter-imperialistas, o problema da guerra e da paz deixava de ser simplesmente um problema teórico para o movimento socialista internacional, passando a exigir respostas políticas práticas e imediatas nos limites nacionais. No Congresso da Internacional Socialista de Stuttgart, em 1907, em que pese as diferenças apresentadas pelos partidos e aquelas suscitadas no interior destes, aprovou-se uma resolução que buscou salvaguardar ainda o princípio de internacionalismo, ao se estabelecer que em caso de eclosão da guerra - já então prevista com a conclusão dos tratados militares entre as potências europeias - os socialistas deveriam sustá-la prontamente e utilizar a crise econômica e política advinda do conflito para precipitar a queda do capitalismo. ${ }^{30} \mathrm{Na}$ visão do historiador Edward H. Carr, mesmo que o movimento operário europeu fosse o único capaz de construir alguma conscientização popular sobre o tema da guerra, o máximo que ele apresentava como resposta eram algumas resoluções um tanto acadêmicas e espaçadas no tempo. ${ }^{31}$

Apesar da retórica revolucionária, ou, ao menos, anticapitalista, do internacionalismo patrocinado em grande parte pela social-democracia alemã, diversos historiadores que se debruçaram sobre o tema afirmam que, ainda que professassem a ortodoxia marxista, os principais líderes do SPD, e o partido como tal, mantinham-se envoltos por uma ideologia antes de tudo democrática radical, enxergando no horizonte nada muito além da possibilidade de democratizar o Estado autoritário - exceto alguns poucos militantes da ala esquerda que romperiam com o partido depois do início da Primeira Guerra. Além disso - ou devido a isso -

\footnotetext{
${ }^{29}$ HOBSBAWM, op. cit., p. 211-2, 217 e 221.

${ }^{30}$ REBERIOUX, op. cit., p. 291-2, 296-7, 304-5.

${ }^{31}$ CARR, Edward H. Vinte anos de crise: 1919-1939. Uma introdução ao estudo das relações internacionais. 2.ed. Brasília: UnB, 2001, p. 45.
} 
seria enganoso acreditar que o SPD, em qualquer estágio de sua existência, representasse alguma ameaça real à sociedade burguesa. ${ }^{32}$

Quando a Primeira Guerra eclodiu, colocando frente a frente os dois blocos de países antagônicos forjados ao longo das quatro décadas precedentes, a Internacional Socialista se viu impotente. Sob as ordens dos altos comandos militares e um surpreendente clamor patriótico, massas entusiasmadas rumaram para os campos de batalha. Ao votarem pelos créditos de guerra exigidos pelos governos, os socialistas alemães justificaram a defesa de sua pátria contra o "barbarismo russo", enquanto os socialistas franceses (e belgas) condenaram a invasão do seu território pela agressora Alemanha. Estava decretada a falência da Internacional Socialista. Quando a social-democracia europeia emergiu das cinzas do pós-1918, já não impunha mais a si a tarefa de revolucionar o mundo. Reabilitados por movimentos pacifistas ou encampando a euforia da vitória nos campos de batalha, os partidos de esquerda do Ocidente europeu reconciliavam-se com reivindicações restritas aos limites do Estado-nação. A consolidação dos social-democratas na vida política institucional expressou um ajustamento dos partidos às vicissitudes da vida política doméstica. Aqueles que permaneceram fiéis à causa de uma internacional revolucionária do proletariado tiveram que criar um novo espaço de atuação partidária. $^{33}$

Com a ruína do império do Czar, onde o já escasso ufanismo arrefeceu mais depressa, os bolcheviques liderados por Lênin se colocaram à testa de uma revolução (ou duas) que alteraria profundamente o curso do socialismo no Ocidente. Com os bolcheviques ascendendo ao poder, enfrentando e vencendo uma dura Guerra Civil, criou-se no Leste europeu um novo polo de atração para o movimento operário internacional, permitindo-se a partir de então a distinção definitiva entre o comunismo - representado por uma nova Internacional a partir de 1919 - e o socialismo, agora em sua versão decididamente "democrática”.

\subsection{Entre-guerras e segundo pós-guerra: conflito e integração}

As consequências da Primeira Guerra teriam impacto profundo e irreversível no curso do Estado moderno. Imersos em tentativas de retorno à estabilidade e ao equilíbrio das economias do período pré-guerra, muitos homens de negócios e policy makers não perceberam

\footnotetext{
${ }^{32}$ LICHTHEIM, G. A short history of socialism. Glasgow: Fontana-Collins, 1970, p. 250.

${ }^{33}$ Ibidem, p. 253-254, 257.
} 
que o caminho das mudanças era sem volta. A guerra mobilizou uma quantidade enorme de recursos de toda natureza, exigindo esforços redobrados de gerenciamento e, como consequência, maior autonomia e fortalecimento do Estado para atuar na economia. O caráter multiclassista das tropas militares, o ingresso de mulheres na indústria, a maior exposição das desigualdades e injustiças sociais e o fortalecimento dos sindicatos criaram, por outro lado, demandas conjuntas que pressionavam por avanços democráticos e maiores igualdades sociais. Finalmente, a introdução de elevadas tributações - toleradas em vista do esforço de guerra seria um recurso fundamental para reformas sociais vindouras. ${ }^{34} \mathrm{Em}$ suma, a conjunção de todos esses fatores forçou o Estado a assumir as funções que antes da guerra eram delegadas à sorte do laissez-faire.

No curso do entre-guerras, no entanto, diversos fatores se chocavam no sentido de retardar esse destino, que se consumaria, de fato, somente após a Segunda Guerra. Tratar-se-ia, na visão de Charles Maier, de um único processo de mais de vinte anos, ao final do qual forças sociais consentiram com o objetivo de dar estabilidade e incrementar a produtividade das economias, em troca de níveis mais elevados de bem-estar. ${ }^{35}$

Entre 1918 e 1921, a agitação operária estendeu-se por toda a Europa, unindo setores revolucionários e reformistas. A guerra não liquidou a unidade do movimento operário internacional nesse curto período, apesar da nova clivagem que passou a identificar os revolucionários comunistas com o modelo bolchevique. A social-democracia obteve um substancial crescimento em número e influência na Europa central e ocidental, enquanto as organizações de classe - dentro ou fora da esfera social-democrata - forçavam sua entrada na linha de frente da política. Em contrapartida, o cenário do pós-guerra fez com que os governos adquirissem consciência da importância de manter a lealdade do operariado organizado. ${ }^{36} \mathrm{Em}$ decorrência, ao pressentirem os desafios à manutenção da hierarquia político-social combinada às inseguranças em relação ao sufrágio de massas - as elites econômicas tiveram de buscar novas estratégias para o restabelecimento de sua legitimidade, para além do emprego da força repressora. Essas estratégias deveriam guiar-se no plano nacional - a partir da política dos Estados ora mais fortalecidos - e nas próprias fábricas, por meio da iniciativa de homens de negócio habilidoso e dispostos a ensaiar novas formas de gerenciamento. Os atores mais afeitos

\footnotetext{
${ }^{34}$ ALDCROFT, Derek H. The European economy 1914-2000. $4^{\mathrm{a} e d .}$ London: Routledge, 2001, p. 5 e 16-18.

${ }^{35}$ Cf. MAIER, Charles. In search of stability. Explorations in historical political economy. Cambridge: Cambridge University Press, 1987.

${ }^{36}$ LICHTHEIM, op. cit., p. 255.
} 
a inovações lançaram-se em busca de "parâmetros científicos de administração" (taylorismo), centralizando a autoridade fabril e construindo uma nova estrutura produtiva a partir da diferenciação e do controle das tarefas, na fábrica. A inovação foi facilitada por setores passíveis de cooptação entre os trabalhadores, sobretudo os trabalhadores especializados e líderes sindicais temerosos de perder sua posição de porta-vozes da classe operária para concorrentes que advogavam, por exemplo, a formação de conselhos de fábricas. ${ }^{37}$ É possível depreender das palavras de Charles Maier que o sucesso dessas iniciativas, combinado com o declínio da movimentação operária no início dos anos 1920, reforçaram o modelo de Estado já estabelecido no final do século XX:

A racionalização era um conceito que compreendia acordos de partilha
transnacionais de mercado e dentro das próprias economias nacionais,
somados a esforços paralelos para reduzir a carga de salários e outros custos
através de investimentos, melhorias técnicas e fusões. Ao mesmo tempo, os
líderes industriais procuravam a legitimação de seu poder, seja ele derivado
do direito de despedir trabalhadores em uma recessão cíclica ou da
colaboração com regimes autoritários como na Itália. A mística gerencial
evocou entusiasmo generalizado, assumindo uma importância de verdadeiro
culto precisamente porque era uma alternativa moderna - e supostamente
acima de interesses de classe - ao ataque socialista anteriormente dirigido
contra as hierarquias industriais. ${ }^{38}$

De modo geral, a começar pelo ambiente da economia política europeia no pós-Segunda Guerra, é possível intuir de antemão que o processo de acomodação dos conflitos entre classes, catalisado pelo impacto da "racionalização econômica", em grande parte, progrediu como esperado pelas elites econômicas europeias. Para tanto, a maior participação dos trabalhadores na renda nacional teria contribuído para um novo arranjo que alinhava empresas e trabalhadores. Voltaremos a este assunto mais adiante.

Ainda que o novo modelo de Estado tenha começado a dar seus passos mais largos embora vacilantes - na década de 1920, os problemas do entre-guerras estiveram longe de garantir solidez às economias europeias em reconstrução. Juntamente à instabilidade políticosocial do início da década, os efeitos do conflito mundial foram, em variados graus, devastadores para a estrutura produtiva e financeira da maior parte dos países beligerantes. Após um breve boom inicial, a elevada demanda de insumos e produtos industriais criada pelas necessidades da guerra não foi reabsorvida pelo consumo dos tempos de paz, deixando fábricas ociosas e um quadro de elevado desemprego, como na Inglaterra, por exemplo. Subsídios

\footnotetext{
${ }^{37}$ MAIER, op cit., p. 163-165.

${ }^{38}$ Ibidem, p. 166.
} 
criados para combater os efeitos do desemprego, auxílios sociais e a manutenção de gastos militares pressionaram as contas dos governos, sacrificando eventuais esforços para um equilíbrio orçamentário. Sem dúvida, a destruição física de redes de transporte, fazendas, casas, fábricas e minas agravou a reestruturação dessas economias, ainda que, nesse aspecto, a intensidade da tragédia tenha variado bastante quando comparados cada território (França e Leste Europeu viram-se mais afetados). A necessidade de créditos externos para financiar importações levou à demanda desenfreada por divisas, com uma consequente depreciação das moedas. Se por um curto intervalo temporal a depreciação do câmbio ajudou a promover exportações e a criar empregos, suas consequências de médio prazo foram desastrosas: aumento dos custos; disparo da inflação; diminuição dos rendimentos; perda de confiança e, eventualmente, fuga de capitais. Os Estados Unidos eram o único país em condições de prestar alguma assistência relevante à causa da reconstrução europeia. Sem entrar na polêmica sobre a ideologia política supostamente isolacionista dos norte-americanos durante esse período, é possível apontar que o país pretendeu atrelar-se o mínimo possível aos problemas da reconstrução do velho continente. ${ }^{39}$

No pós-1918, líderes das nações aliadas chegaram a dar impressão de que um plano multilateral de revisão para a Europa seria colocado em prática. Essas expectativas poderiam ser expressas, por exemplo, pelos Quatorze Pontos de Woodrow Wilson, prevendo regras democrático-liberais aos países derrotados, ou pela criação da Liga das Nações - que inclusive incorporou "bandeiras" dos programas do movimento operário. Dispondo de estoques de alimentos e matérias-primas, os Estados Unidos organizaram um programa de auxílio governamental à Europa ainda em 1918, mas, no ano seguinte, o programa foi cortado e confiado à iniciativa privada. As imprecisões quanto à capacidade de pagamento dos países outrora inimigos tornou a tarefa da reconstrução mais difícil no centro e no leste da Europa. A perspectiva de soluções harmônicas entre as nações foi logo minada pelas divergências nos interesses dos governos: os norte-americanos preocupavam-se em reaver os empréstimos concedidos aos aliados, enquanto Reino Unido e França contavam com o pagamento das reparações impostas aos alemães para arcar com as suas próprias dívidas. Os Estados Unidos recusaram-se a resolver a problemática dos créditos e débitos franceses e britânicos diretamente com a Alemanha, alegando uma grande probabilidade de calote por parte dos alemães, dos quais

\footnotetext{
${ }^{39}$ ALDCROFT, op. cit., p. 23 e 29; FEINSTEIN, Charles H; et al. The world economy between the World Wars. Oxford: University Press, 2008, p. 25-26.
} 
herdariam um saldo muito maior de dívidas podres. A grande inflação alemã de 1922-3 tornou a intrincada situação ainda mais dramática. ${ }^{40}$

Com um breve interregno entre 1924 e 1928, tudo foi dramático na Alemanha do entreguerras. Em fins de setembro de 1918 estava claro para o Alto Comando Militar alemão e para os representantes do Reich que a guerra não poderia ser vencida. As tentativas de salvar a monarquia não deram certo e, de forma surpreendente, o imperador caiu diante da pressão das massas que irromperam exigindo a paz a todo custo. Após a insurgência de marinheiros e soldados na cidade de Kiel, o movimento revolucionário espontâneo alastrou-se pela Alemanha, rendendo todo o aparato burocrático e militar do antigo regime e criando conselhos de operários e soldados em diversas cidades. Nenhuma força política tinha uma estratégia clara, mas a iniciativa estava nas mãos dos setores da esquerda, enquanto que os representantes da direita e alguns partidos da classe média liberal permaneciam paralisados. Assumindo desde o início o governo provisório, o SPD era naquele momento o partido com maior capacidade de tomar as rédeas da explosiva situação do mês de novembro, e buscou fazê-lo abortando paulatinamente as tentativas das organizações mais radicais que, com diferentes táticas, previam tornar os conselhos a base de um novo governo revolucionário. Após a rendição aos aliados, as lideranças do SPD, agrupados em torno de Friedrich Ebert, consideraram conveniente normalizar as funções do Estado, adiar reformas sociais e consolidar um novo governo parlamentar através da convocação de uma Assembleia Nacional Constituinte - recebendo para esta finalidade o apoio do Alto Comando Militar alemão, que permanecera intacto e recobrava o fim das tensões domésticas. $^{41}$

O outrora partido-líder do movimento operário internacional via-se impelido a estabelecer um modelo de democracia parlamentarista cujos pilares não estavam claros, sustentando apenas uma repulsa à experiência soviética que se desenvolvia na Rússia. Afinal, como vimos, a concepção teórica que havia estado em voga no SPD no período que precedeu a Primeira Guerra, era a de que o socialismo deveria ser alcançado pelo caminho da democracia. Além disso, a democracia socialista pressupunha um alto índice de industrialização e a manutenção das liberdades políticas conquistadas no passado. Assim, o recurso da antipropaganda do "terrorismo bolchevique", utilizado pelos social-democratas contra seus oponentes revolucionários, serviu a uma defesa da democracia parlamentar reforçada pelo

\footnotetext{
40 ALDCROFT, op. cit., p. 18-22; LICHTHEIM, op. cit., p. 256.

${ }^{41}$ KOLB, Eberhard. The Weimar Republic. $2^{\mathrm{a}}$ ed. London: Routledge, 2005, p. 4-13.
} 
argumento de ser essa a única opção de modelo político para um país civilizado. Como que levada por certo automatismo, fatalismo e confiança própria, a social-democracia alemã concebeu que a armadura da velha autocracia militarista poderia ser progressivamente removida de forma pacífica. Essas perspectivas, cultivadas ao longo dos vários anos precedentes, explicariam o porquê de a experiência do SPD no pós-1918 ter sido marcada por uma profunda incapacidade de formular políticas de curto prazo. ${ }^{42}$

Essa incapacidade foi demonstrada, por exemplo, na elaboração da Constituição da República de Weimar, após os trabalhos da Assembleia Nacional Constituinte, reunida entre fevereiro de 1919 e junho de 1920, longe da agitação vermelha de Berlim. Ainda que as eleições de janeiro tivessem dado ampla maioria dos assentos da Assembleia ao SPD, o partido emprestou pouco de seu programa ao documento final, prevalecendo as ideias de liberais burgueses e da esquerda-liberal oriundas dos partidos que, com os socialistas, formaram a “Coalizão de Weimar", dando sustentação inicial ao novo regime. Um outro fator, no entanto, deve ser considerado no que se refere à contenção dos impulsos socializantes. A "racionalização econômica" - ou alguns elementos do que o termo sugere -, pareceu ter cumprido um papel importante na Alemanha durante a montagem da República de Weimar. Ainda em novembro de 1918, um acordo foi assinado entre patrões, dispostos a fazer concessões, e sindicalistas partidários do que se chama hoje "sindicalismo de resultados" - hostis, portanto, à maré revolucionária. Os patrões reconheceram a legitimidade dos sindicatos em negociação, aceitaram a jornada de 8 horas de trabalho sem diminuição de salário, contrato coletivo e comissões paritárias para regular conflitos trabalhistas. As conversações entre as partes começaram antes mesmo da queda da monarquia, quando parte da elite econômica percebeu que não poderia depender somente do Estado para manter suas posições no mercado. Assim, a cooperação com quadros da "elite sindical" contribuiu para refrear anseios socializantes, lançando-se um tipo de compromisso que acabou prosperando durante o processo de constitucionalização da República e tomou mais força - não apenas na Alemanha - quando, na segunda metade da década de 1920, atingiu-se a estabilização monetária sob o Padrão-Ouro, o que renovou a competição internacional por mercados. ${ }^{43}$

Havia transformações profundas em curso no mundo do trabalho, capitaneadas pela grande burguesia e setores do operariado, mas com impactos que certamente abrangiam toda a

\footnotetext{
${ }^{42}$ LICHTHEIM, op. cit., p. 260-265; KOLB, op. cit., p. 12.

${ }^{43}$ KOLB, op. cit., p. 20-21; LOUREIRO, Isabel. A Revolução Alemã, 1918-1923. São Paulo: UNESP, 2005, p. 69 (é da autora a alusão ao "sindicalismo de resultados"); MAIER, op. cit., p. 166.
} 
classe trabalhadora. Ao mesmo tempo, o grande tributário da República de Weimar, o SPD, perdera a capacidade de antecipar-se aos acontecimentos ou de arquitetar reformas que atendessem às suas antigas bases sociais, que cada vez mais se acomodavam, perdendo vínculos mais estreitos com o partido. Até 1923, porém, a afirmação da ordem liberal na Alemanha chocou-se com uma caótica situação de instabilidade social, acentuada pelos esforços do governo em suprimir ocupações, greves e ações da esquerda e conter as constantes tentativas de golpe da extrema-direita. Oficiais e elementos do judiciário, mantidos em seus postos pela nova Constituição, eram geralmente simpáticos às expressões políticas antirrepublicanas, contribuindo para solapar ainda mais os alicerces do novo regime. ${ }^{44}$

Em seguida à instauração da República de Weimar, a questão das reparações a serem pagas pela Alemanha aos aliados dominou a política internacional. Ao serem impostas pesadas condições à Alemanha com a assinatura do Tratado de Versalhes, não se fixou, contudo, o montante e os prazos para o pagamento dessas reparações. Em 1921, uma comissão internacional designada para estabelecimento das normas calculou os valores em uma quantia exorbitante. Além de a política monetária alemã estar devastada, agravaram a situação a falta de suporte internacional para o incremento das exportações do país, as barreiras tarifárias e outras formas de pressão de grupos de interesse franceses e ingleses contra as empresas alemãs. Do lado alemão, protelou-se a estabilização da moeda, e a inflação foi a arma dos negociadores que podiam alegar a falta de uma base de cálculo para proceder aos pagamentos. ${ }^{45}$

Em janeiro de 1923, o primeiro-ministro francês Raymond Poincaré, do bloco nacionalista e conservador, ordenou a ocupação militar da região alemã do Ruhr, contando também com o apoio de tropas belgas. Um governo alemão enfraquecido, do qual o SPD já não mais fazia parte, conclamou a população à resistência pacífica na região ocupada, mas a forte pressão político-econômica acabou derrubando o chanceler Wilhelm Cuno. A nova liderança de Gustav Stresemann - à frente de um gabinete que trouxe de volta o SPD, ainda que em um papel de figurante - alterou o curso das relações internacionais da Alemanha nos anos 1920. A chancelaria de Stresemann seria breve (pouco mais de cem dias), mas ele continuaria na linha de frente da política externa alemã até sua morte em 1929. Na chamada "Era Stresemann", chegou-se ao controle da hiperinflação alemã e à reforma do marco, abrindo caminho para a adoção do Plano Dawes (1924), que estabeleceu critérios mais razoáveis para o pagamento das

\footnotetext{
${ }^{44}$ KOLB, op. cit., p. 36-39.

${ }^{45}$ Ibidem, p. 41-42.
} 
reparações. A partir desse plano, estreitaram-se os negócios entre alemães e norte-americanos, em um momento em que os primeiros necessitavam de capital e os últimos viviam um grande expansionismo econômico, e buscavam oportunidades de exportação maciça de capital. ${ }^{46}$

Uma série de fatores levou a política externa europeia a alterações substanciais nesse período, permitindo algum grau de cooperação entre governos e o arrefecimento das tensões envolvendo a Alemanha - bem como as próprias mudanças ocorridas nesse país, já descritas acima. Em 1924, o Labour Party, suplantando os liberais como principal força de oposição aos conservadores, chegava pela primeira vez ao poder no Reino Unido. O pano de fundo da atuação dos trabalhistas britânicos parecia se tornar aquele desejado em vão pelos socialdemocratas alemães, isto é: industrialização em elevado grau, operariado representando a maior parcela do eleitorado e um regime parlamentar sólido (mesmo sob a vigência de uma monarquia constitucional). Em 1918, a plataforma moderada do sindicalismo fabiano sobrepôs-se à corrente revolucionária na disputa interna do Labour Party, pois uma vez que o livre mercado passou a ser crescentemente questionado, com a Primeira Guerra o socialismo reformista reuniu melhores condições de ocupar o espaço deixado vago pelo liberalismo. ${ }^{47}$ Apesar de frágil e curto, o governo do primeiro-ministro trabalhista Ramsay MacDonald (janeiro a novembro de 1924) lançou uma política externa mais ativa, buscando conciliar França e Alemanha, fortalecer a Liga das Nações e estabelecer relações diplomáticas com a União Soviética. Antes da chegada ao poder, os trabalhistas já denunciavam o desarmamento unilateral e as reparações impostas à Alemanha, medidas vistas como destinadas a levar a economia alemã à ruina e, com ela, toda a economia europeia. Mesmo com a derrota do Labour Party para os conservadores, a política externa britânica continuou perseguindo a mesma linha de equilibrar as relações entre os Estados europeus. ${ }^{48}$

Outra mudança importante ocorreu na França, onde, a partir da crise do franco, em 1923, o governo viu-se obrigado a fazer concessões aos interesses da política externa dos Estados Unidos e do Reino Unido, empenhados em chegar a bons termos com a Alemanha. A ocupação do Ruhr e a resposta da resistência pacífica causaram desgastes aos franceses e, em 1924, chegava ao fim o governo do bloco da direita nacionalista. Em seu lugar assumiu a coalizão do

\footnotetext{
${ }^{46}$ Ibidem, p. 47-48, 59-61.

${ }^{47}$ Fabianismo: movimento sócio-político britânico, fundado em Londres (1884), cuja finalidade era a elevação da classe operária para torná-la apta a assumir o controle dos meios de produção.

${ }^{48}$ LICHTHEIM, op. cit., p. 259; KOLB, op. cit., p. 54-55; WINKLER, Henry L. The emergence of a labor foreign policy in Great Britain, 1918-1929. The Journal of Modern History, Vol. 29, n. 3, set. 1956, p. 247-258. The University of Chicago Press, p. 248.
} 
Cartel des Gauches, formado pela aliança entre o Partido Radical e o Partido Socialista. O novo governo estreitou relações com o Reino Unido e, seguindo a mesma orientação dos britânicos, optou por uma política conciliatória com a Alemanha - promovendo, dentre outras medidas, a desocupação do Ruhr - além de também estabelecer relações diplomáticas com a União Soviética. Quanto a esta, cabe mencionar que mesmo as mudanças, ocorridas na diplomacia internacional em meados da década de 1920, não tiraram os soviéticos do isolamento. A revolução não havia se espalhado pela Europa como previsto pelos bolcheviques, e o enorme país devastado e em posição defensiva, sem o governo saber o que fazer exatamente para preservar sua existência, encontrou nas flexibilizações pró-iniciativa privada da "Nova Política Econômica" sua solução própria para impedir o colapso do regime. ${ }^{49}$

A estabilização monetária tão desejada por banqueiros europeus e norte-americanos pôde enfim se alcançada, e a volta do Padrão-Ouro, associado nostalgicamente à estabilidade do sistema pré-guerra, confirmou-se entre 1924 e 1928, período em que Alemanha, Reino Unido, Itália e França o adotaram..$^{50}$ Paralelamente, os Tratados de Locarno (1925) e o Pacto Briand-Kellogg (ou Pacto de Paris, 1928) foram firmados com a intenção de conferir mais estabilidade e critérios de arbitragem entre as nações e, como um dos desdobramentos desses esforços diplomáticos, a Alemanha foi aceita na Liga das Nações em 1926. No Reino Unido, os rumos da política internacional confluíam pouco a pouco para as teses pacifistas do Labour Party, enquanto que este aderia progressivamente às políticas que serviriam de base ao direito internacional do segundo pós-guerra. O partido preparava-se, assim, para as responsabilidades do poder que viriam a seguir, além de ter estreitado relações com políticos e formuladores liberais. ${ }^{51}$ Como veremos mais à frente, a aproximação entre trabalhistas e liberais ganharia maior relevância após a Grande Depressão, fazendo com que cada vez mais diminuíssem as linhas que separavam a esquerda reformista das reformas propugnadas pelo campo dos economistas liberais.

Subsistia, contudo, a questão da Renânia, região ocupada por força do Tratado de Versalhes, cuja evacuação os alemães desejavam ver concluída o mais rápido possível. $\mathrm{O}$ governo francês resistiu a uma saída prematura, pois exigia em troca o pagamento das

\footnotetext{
${ }^{49}$ KOLB, op. cit., p. 55-59; FEINSTEIN, op. cit., p. 11. Ainda em 1922, os governos da União Soviética e da Alemanha assinaram o Tratado de Rappalo, com vistas a atingir maior abertura de trocas e obter um melhor lugar na diplomacia internacional.

${ }^{50}$ MAIER, op. cit., p. 156; ALDCROFT, op. cit., p. 5.

${ }^{51}$ WINKLER, op. cit., p. 257-258.
} 
reparações ao qual estavam condicionados tanto a estabilização do franco quanto as obrigações com seus credores norte-americanos e britânicos. A questão das reparações tornou-se novamente aguda na agenda política europeia e, para contorná-la, produziu-se o Plano Young, que agradou às partes envolvidas. O plano foi ratificado no Reichstag em março de 1930, não sem enfrentar uma campanha, realizada pela direita nacionalista alemã, que se opunha aos termos da política externa conciliatória. Às vésperas do impacto da Grande Crise de 1929, a temperatura política na Alemanha já dava sinais de novo aquecimento. ${ }^{52}$

A crise iniciada nos Estados Unidos, cuja influência sobre a economia mundial se comprovaria com o aprofundamento e a gravidade da Depressão, fez com que as condições econômicas se deteriorassem em todos os lugares, sobretudo ao longo do biênio 1930-1931. Juntamente ao colapso da atividade econômica, todo o esforço de engenharia internacional com base na cooperação econômica e financeira foi por água abaixo - e no quadro da diplomacia europeia, a importância da Liga das Nações, na década de 1930, seria insignificante. Do mesmo modo que na Primeira Guerra, a participação dos governos nas economias aumentou em boa medida nos anos seguintes à Grande Depressão; na maioria dos países, o primeiro ato dos governos foi o abandono do Padrão-Ouro e a desvalorização das moedas, seguido de uma série de mecanismos protecionistas para salvaguardar as economias nacionais de influências externas. $^{53}$

Dentre os efeitos da queda da produção, dos investimentos e dos preços, sem dúvida alguma, o mais grave foi o dos altos índices de desemprego. Nos anos 1930, o tema se faria presente em todos os debates políticos, dividindo partidos e criando clivagens entre policy makers:

Antes da Primeira Guerra Mundial, temas como política monetária, tarifas,
taxas e regulação dos monopólios dominaram os debates políticos e as
campanhas eleitorais; nos anos 1930, a questão do desemprego tomou
definitivamente o centro das atenções. Alguns diriam que o desemprego foi
"descoberto" nas últimas décadas do século XIX, mas tornou-se um tema
econômico, social e politicamente relevante somente nos anos 1920 e,
principalmente, durante a Grande Depressão. ${ }^{54}$

A mudança de prioridades no debate político e econômico nos tempos de desemprego em massa refletiu mais intensamente as mudanças na relação entre Estado e mercado, nas

\footnotetext{
${ }^{52} \mathrm{KOLB}$, op. cit., p. 65-66.

${ }^{53}$ ALDCROFT, op. cit., p. 64-76.

${ }^{54}$ FEINSTEIN, op. cit., p. 113.
} 
relações de trabalho, na atuação dos sindicatos e nos novos parâmetros do conflito social aos quais nos referimos até aqui. Ao passo que se legitimavam os discursos que previam adequar progressivamente a ordem econômica a essa viragem societária, os partidos social-democratas, adaptando-se ao novo cenário, se dispunham a integrar-se às discussões que previam remediar o desemprego massa, deixando de lado o ímpeto radical de outras épocas. Consequentemente, os conflitos destinavam-se a ser resolvidos dentro da órbita do Estado.

Com o desemprego em massa tornando-se a principal preocupação política e social, ficava claro que a questão não poderia ser tratada nas mesmas bases do passado, ou seja, com medidas assistenciais convencionais. Embora as medidas governamentais levadas a cabo para reorganizar o mercado de trabalho tenham variado em cada país, em quase todo o mundo enraizava-se uma postura intervencionista que se desenvolveria de forma mais ampla após a Segunda Guerra. A Grande Depressão soterrou ainda mais as crenças no livre-mercado, aprofundando a convicção de que o Estado, mediante políticas apropriadas, seria o grande responsável pela promoção do pleno-emprego. ${ }^{55}$ É a partir desse período que a palavra de ordem do planejamento econômico, sutilmente apropriada da experiência soviética nas décadas de 1920 e 1930, passou a permear o discurso até dos mais radicais anticomunistas. ${ }^{56}$

No Reino Unido, país relativamente menos afetado pela Grande Depressão - mas com taxas de desemprego alarmantes -, John Maynard Keynes seguia desde os anos 1920 alinhado ao Partido Liberal, defendendo um vasto programa de obras públicas financiadas por empréstimos. Sua pregação, no entanto, não foi capaz de convencer os setores mais ortodoxos da elite político-econômica. Sua obra teórica mais conhecida e influente viria posteriormente com A Teoria Geral do Emprego, do Juro e da Moeda, publicada em 1936. ${ }^{57}$ Antes disso, porém, as propostas de Keynes fizeram sucesso entre os trabalhistas no momento em que estes, com o apoio dos liberais, chegavam novamente ao poder em 1929. Contudo, ao curvar-se diante dos representantes do Tesouro, contrários às inovações, o primeiro-ministro MacDonald provocou um racha em seu gabinete, em 1931, causando grande revés no Labour Party. Com o apoio dos conservadores, um novo governo seria montado por MacDonald, já afastado das fileiras trabalhistas. ${ }^{58} \mathrm{O}$ Labour Party permaneceria na oposição até que fosse composto o

\footnotetext{
${ }^{55}$ Ibidem, p. 128.

${ }^{56}$ HOBSBAWM, Eric. A era dos extremos: o breve século XX. Tradução de Marcos Santarrita. São Paulo: Companhia das Letras, 1994, p. 51-53. 99-100.

${ }^{57}$ ALDCROFT, op. cit., p. 61; FEINSTEIN, op. cit., p. 128-129.

${ }^{58}$ LICHTHEIM, op. cit., p. 289; SASSOON, op. cit., p. 56-57.
} 
governo de coalização nacional em 1940, como parte do esforço de guerra. Em melhores condições políticas, o partido teria, ao final da guerra, uma nova oportunidade para reabilitarse diante da classe trabalhadora, virando a página do grande fracasso, que foi a tentativa de conter o desemprego em massa, no início dos anos 1930.

A recuperação do Reino Unido ficaria a cargo dos proponentes de uma interferência um tanto quanto limitada do Estado, na economia, se comparada às perspectivas intervencionistas mencionadas acima. A desvalorização da libra (cheap money) e o protecionismo comercial trouxeram resultados modestos e insuficientes para combater o desemprego ao longo da década. Sem que se praticasse uma política fiscal expansionista, manteve-se equilibrado o curso do orçamento, apostando-se na eficiência do setor privado e temendo-se que gastos públicos desencadeassem um processo inflacionário. Algumas medidas limitadas de auxílio industrial apenas ajudaram a sustentar indústrias pouco rentáveis, voltadas para a exportação, em um momento em que o comércio internacional se contraía. Mais rentáveis, porém, foram os setores da habitação e das novas indústrias, voltadas ao mercado interno, que ajudaram em uma recuperação gradual da economia. Alguns sinais de melhoria do desempenho econômico viriam mais tarde, quando o rearmamento trouxe maiores excedentes às contas do governo. ${ }^{59} \mathrm{Se}$ os trabalhistas fracassaram no início da década de 1930, a amarga política econômica dos conservadores talvez tenha tido um desempenho ainda pior em termos de sanar a insegurança dos trabalhadores. No entanto, a expansão do mercado interno possivelmente serviu de contrapeso dessa situação, ao produzir novas expectativas baseadas no consumo de bens duráveis.

Em 1933, o novo governo da Suécia, formado pela coalizão entre o Partido SocialDemocrata e o Partido Agrário, mostrou-se mais sensível à incorporação das propostas de um grupo de economistas locais que advogavam a substituição da política monetária deflacionária por uma política fiscal anticíclica com déficits financiados através de empréstimos governamentais. No primeiro ano do novo governo, a taxa de desemprego no país começou a declinar, embora uma política monetária mais expansionista iniciada no ano anterior também tenha contribuído para esse efeito. ${ }^{60}$ Segundo Adam Pzreworski e Michael Wallestein, a disposição de governo sueco de superar a "questão social" nos marcos meramente

\footnotetext{
${ }^{59}$ ALDCROFT, op. cit., p. 78-79.

${ }^{60}$ FEINSTEIN, op. cit., p. 131.
} 
assistencialistas teria sido "o começo do casamento da esquerda com a economia keynesiana"61. Começava aí um longo período de predomínio social-democrata na Suécia, acompanhado em menor grau pela presença constante de partidos congêneres no resto da Escandinávia, sobretudo após a Segunda Guerra. Assim, no segundo pós-guerra, a região estaria estreitamente associada a exemplos bem-sucedidos de montagem do Estado de Bem-Estar Social. Conforme George Lichtheim, desde os anos 1920 a Escandinávia encontrou condições favoráveis que impediram traumas como os verificados nos demais países da Europa Ocidental no entre-guerras: países com economias pequenas nos quais a democracia não foi seriamente abalada, amenas tensões de classe e pouca interferência de problemas militares na vida civil. ${ }^{62}$ Acrescenta-se que, no segundo pós-guerra, a Suécia experimentaria uma situação muito melhor do que o da devastação física ou econômica enfrentada pela quase totalidade da Europa. ${ }^{63}$

Até 1936, a estratégia dos governos franceses para a recuperação baseou-se em evitar os riscos de inflação mantendo intocável o Padrão-Ouro. Como o impacto da depressão chegou mais tarde à França, e o balanço de pagamentos permaneceu forte, o grande estoque de ouro acumulado durante os anos anteriores deu confiança ao prosseguimento de uma política econômica independente. No entanto, o impacto da desvalorização das moedas estrangeiras onerou o ajuste da economia francesa, implicando altas taxas de juros e perda da confiança dos empresários. A partir de 1931, políticas deflacionárias começaram a ser aplicadas, diminuindo salários, derrubando preços, restringindo a atividade comercial e reduzindo drasticamente os gastos do governo. De nada adiantou: até 1936, a produção declinou e o desemprego disparou. ${ }^{64}$

O agravamento da depressão e o descontentamento social na França abriram caminho para a vitória eleitoral, em 1936, do governo de Frente Popular, liderado pelo Partido Socialista de Leon Blum, e composto ainda pelo Partido Radical e pelo Partido Comunista - este seguindo a nova linha do Comintern que, diante da ascensão do fascismo, havia abandonado sua política sectária ("terceiro período") em 1934. O programa inicial dos socialistas concebia reformas estruturais e nacionalizações. Os comunistas, por sua vez, tinham planos mais moderados, preocupando-se em não perder o apoio da classe média eventualmente seduzida pelo fascismo - a ponto de o Partido Comunista sequer ter exigido postos no novo gabinete. As circunstâncias,

\footnotetext{
${ }^{61}$ PRZEWORSKI; WALLESTEIN, op. cit., p. 31.

${ }^{62}$ LICHTHEIM, op. cit., p. 288.

${ }^{63}$ ALDCROFT, op. cit., p. 105.

${ }^{64}$ ALDCROFT, op. cit., p. 79-80.
} 
contudo, levaram a Frente Popular para caminhos distantes do radicalismo. Inicialmente, Blum instituiu um programa expansionista ("New Deal francês") que objetivava restaurar o poder de compra, estabelecer um fundo para os desempregados, executar obras públicas e apoiar fazendas comunitárias. No entanto, uma onda de greves irrompeu pressionando por medidas mais radicais, o que alarmou tanto o patronato quanto os próprios socialistas e comunistas estes últimos preocupados com a possibilidade de que a agitação social viesse a se converter em prematura reviravolta social. O governo reagiu negociando o aumento de salários e a redução da jornada de trabalho, sem encontrar oposição dos assustados empresários. A política econômica, porém, mostrou-se um fracasso: a escassez de empregos e a estagnação econômica continuaram. Com ministros e assessores pouco preparados para providenciar alternativas à ortodoxia econômica, Blum cedeu às políticas deflacionárias, enquanto que os proprietários respondiam ao cenário com a fuga em massa de capitais. O primeiro-ministro, então, requisitou a um senado sob domínio dos conservadores poderes especiais para lidar com a situação, o que lhe foi negado. Blum deixou ao cargo em junho de 1937, passados pouco mais de um ano de governo. Seu sucessor, Camille Chautemps, do Partido Radical, conseguiu do senado aquilo que fora recusado a Blum, produzindo, em seguida, nada além de um programa deflacionário tradicional. Porém, os insucessos de Chautemps permitiram a Blum retornar ao posto de primeiro-ministro por pouco tempo. Um novo fracasso, no entanto, resultou na volta dos conservadores ao poder. Estes buscaram reverter a tendência declinante da atividade econômica estimulando um rápido aumento das despesas militares entre 1938 e $1939 .{ }^{65} \mathrm{O}$ desempenho catastrófico da economia francesa na década de 1930, em contraste com a recuperação dos anos 1920, deixou o terreno mais fácil para a invasão nazista em 1940.

Em uma Europa já atribulada e a caminho da guerra, a esquerda francesa falhou após haver chegado de forma notável ao poder. Enquanto a agitação operária era em certa medida forte e radical, e o fascismo conquistava simpatias entre determinados setores da França, o governo preferiu caminhar no fio da navalha. Nas questões externas, destaca-se que a Frente Popular preferiu não intervir na Guerra Civil Espanhola em socorro à Frente Popular do outro lado dos Pireneus - exceção feita aos indivíduos que voluntariamente juntaram-se à Legião Estrangeira Espanhola. O papel importante na Resistência, durante a Segunda Guerra, daria nova oportunidade para a reabilitação dos socialistas, mas em um papel secundário. Os

\footnotetext{
${ }^{65}$ SASSOON, op. cit., p. 54-6; ALDCROFT, op. cit., p. 80; FEINSTEIN, op. cit., p. 149; LICHTHEIM, op. cit., 292.
} 
comunistas, no entanto, angariariam grande prestígio popular, mas seriam barrados das tarefas de reconstrução.

Após um breve período de estabilidade entre 1929 e 1930, a Alemanha viveu em 1932 o pior momento causado pela Grande Depressão, e a exorbitante taxa de desempregados atingiu seu nível máximo. O governo do chanceler Heinrich Brüning, no princípio hesitante em abandonar as políticas deflacionárias - às quais confiava uma retomada da geração de empregos -, cedeu à opinião pública e promoveu a construção de obras públicas. A política teria sequência no governo de Franz von Papen, quando as reparações já haviam chegado ao fim (Conferência de Lausanne), e no de seu sucessor, Kurt von Schleicher. Esses dois últimos governos marcaram, pela primeira vez, a chegada ao poder do Partido Popular Nacional Alemão, representante da extrema-direita nacionalista-conservadora, monarquista e antissemita. $\mathrm{O}$ governo de Schleicher favoreceu a expansão de créditos supervisionados por agências governamentais e com forte sustentação pelo Reichsbank, agradando a industriais e grandes proprietários rurais. Esses setores, que jamais se curvaram ao modelo democrático, mesmo nos seus períodos de maior estabilidade, viram nesse momento condições favoráveis para lançar uma ofensiva na direção de um regime autoritário. ${ }^{66}$

Os termos dessa ofensiva começaram a ter contornos finais com a transformação do Partido Nazista em um partido de massas, bradando lemas nacionalistas e antidemocráticos, na esteira da fragilização do sistema político e do crescente conflito social a partir de 1929. Em 1930, o partido havia obtido uma votação impressionante, sobretudo com o apoio dos jovens e de diferentes grupos sociais que se desvinculavam do tradicional Partido Popular Nacional Alemão ou dos partidos liberais. Do outro lado, o Partido Comunista também crescia em influência, capturando o eleitorado do SPD que, apesar de tudo, ainda era o maior partido no Reichstag. A partir de 1931, uma porção pequena de importantes industriais e banqueiros aproxima-se do Partido Nazista. Porém, não foi o financiamento aos nazistas o que determinou a chegada destes ao poder, mas sim a influência exercida por aquela elite sobre o presidente da Alemanha, Paul von Hindenburg, que decidiu intervir na política parlamentar e entregar a Adolph Hitler o cargo de chanceler. ${ }^{67}$

\footnotetext{
${ }^{66}$ FEINSTEIN, op. cit., p. 132-133; KOLB, op. cit., p. 115.

${ }^{67}$ KOLB, op. cit., p. 101-115. A "Constituição de Weimar" criou um modelo de executivo formado por um chanceler e um presidente. A cada sete anos previa-se eleição para presidente. Com a intenção de evitar o "absolutismo parlamentar", o Artigo 48 previa que o presidente poderia agir para proteger as leis da República, mesmo em face da oposição do gabinete no governo e do Reichstag (que poderia ser dissolvido). O Artigo 48
} 
No poder e com o apoio da alta burguesia, Hitler lançou um modelo ampliado de criação de empregos (Programa Reinhardt), superando em escala o programa instituído por seus antecessores. No entanto, o principal êxito na liquidação do desemprego em massa ocorreu quando os gastos militares foram expandidos, promovendo um maior estímulo à demanda agregada. ${ }^{68} \mathrm{O}$ dirigismo da economia com o suporte da burguesia financeira deu base para a renovação do expansionismo alemão e pavimentou o caminho para uma nova carnificina mundial.

Em 1934, social-democratas e comunistas já haviam sido trucidados na Alemanha e na Áustria e, na Itália, Benito Mussolini já havia intensificado o mesmo processo a partir de $1925 .{ }^{69}$ Nesse último país, contudo, o sucesso da Resistência traria novamente a esquerda para primeiro plano, e a unidade formada por socialistas e comunistas contra o fascismo sobreviveria por algum tempo, diferentemente do que ocorreu nos outros países da Europa. Na Europa Central, a social-democracia chegaria novamente ao poder apenas no final da década de 1960.

Nos anos 1920, trabalhistas britânicos e socialistas franceses atuaram em prol da manutenção da paz no campo da diplomacia internacional. Diferentemente do comportamento da social-democracia europeia que, antes do estouro da Primeira Guerra manifestava-se à margem da política dos Estados, no entre-guerras os partidos de base operária apresentaram suas próprias propostas para modificar a política externa dos seus respectivos países. No cerne da vulnerabilidade europeia estavam as questões internas e externas da Alemanha. Com a emergência do fascismo e o rearmamento do continente, o curso dos acontecimentos seria, uma vez mais, profundamente alterado. Ao contrário de 1914, em 1939 não havia dúvida sobre quem era o agressor, e tampouco houve hesitações em formar amplas alianças contra o inimigo comum com as forças comprometidas com sistemas de governo democrático.

Imediatamente após a derrota do fascismo na Segunda Guerra, a Europa quase toda estava em ruínas, beirando a miséria em diversas regiões, com o quadro mais grave no centro e no leste do continente - onde vastos deslocamentos populacionais agravavam o estado de

também permitia ao presidente proclamar estado de emergência quando "a ordem e a segurança pública" estivessem em perigo, e instituir leis de exceção. Essas prerrogativas foram utilizadas abusivamente pelo presidente Hindenburg (1925-1934) entre 1930 e 1933. Mas também foram utilizadas pelo presidente Ebert (1919-1925) com a alegação da necessária garantia da ordem durante o ano de 1923. Cf. VINCENT, Paul C. A historical dictionary of Germany's Weimar Republic, 1918-1933. London: Greenwood Press, 1997, p. 74.

${ }^{68}$ FEINSTEIN, op. cit., p. 133.

${ }^{69}$ LICHTHEIM, op. cit., p. 287-288. 
penúria e sofrimento. De modo geral, conforme Derek Aldcroft, a produção industrial, a atividade agrícola e o comércio foram paralisados, as comunicações foram seriamente debilitadas, sobrevindo uma severa escassez de praticamente quase tudo. Enormes déficits orçamentários acumularam-se, enquanto as reservas cambiais declinaram a níveis baixíssimos, em um cenário que provocava agudas pressões inflacionárias. Entretanto, ao contrário do que ocorrera ao término da Primeira Guerra, e apesar das destruições em massa, a perda de ativos produtivos não foi tão grave, sobretudo na Europa ocidental, tornando possível um retorno aos níveis de produção do pré-guerra logo nos primeiros anos após o conflito bélico. Assim, a destruição do capital não foi o aspecto mais preocupante para essas economias durante esse período, mas sim a desorganização da produção como resultado da desmobilização da indústria bélica, escassez de matérias-primas essenciais, reparos pendentes de instalações, gargalos nas linhas de comunicação e, principalmente, a exaustão da população, submetida a toda a sorte de sacrifícios durante os seis anos da guerra. Convulsões sociais e políticas emergiram novamente, e a posição dos governos via-se abalada ainda por elevadas dívidas públicas, ondas inflacionárias e a maciça perda de mercados. Estava claro para esses governos, como ocorreu após a Primeira Guerra, que as importações eram urgentemente necessárias para recuperar a produção, mas o potencial baixo de exportação dificultava a aquisição de divisas para as realizar. Entraria em cena, então, a contribuição decisiva dos Estados Unidos como nação provedora fundamental da reconstrução europeia, agora determinada a uma intervenção em nada comparável à timidez verificada após $1918 .^{70}$

Para Alan Milward, no entanto, a importância dos Estados Unidos para a estabilidade político-econômica na Europa deve ser relativizada. Segundo o autor, de fato, os norteamericanos mostraram-se motivados a uma participação ativa na reconstrução europeia, graças a uma retórica baseada na suposição de que o velho continente estava à beira do colapso, colocando em xeque o futuro de todo o sistema econômico capitalista e, por conseguinte, ameaçando a segurança dos próprios Estados Unidos. Dessa forma, a propaganda em favor do Plano Marshall (oficialmente Programa de Recuperação Europeia), em ambos os lados do Atlântico, fortaleceu os medos do aprofundamento da crise e as esperanças dos círculos que confiavam na importância fundamental do programa. A adoção do Plano Marshall seria facilitada, em seguida, pela retirada da União Soviética da Conferência de Paris e o crescente clima polarizado pela propaganda da Guerra Fria no Leste e no Oeste.

$\overline{{ }^{70} \text { ALDCROFT, op. cit., p. 104-111. }}$ 
Contudo, conforme destaca Milward, não havia evidências que apontassem para uma crise iminente na Europa. Os altos níveis de produção e emprego durante a guerra teriam sido mantidos na maioria dos países; não houve falências de bancos, lucros e investimentos seguiram curso crescente. Enquanto as experiências do pós-1918 refletiam nos presságios de uma acentuada contração, na realidade o boom da reconstrução transformou-se em uma tendência geral de crescimento e prosperidade que se manteria até $1967 .^{71}$

Após 1945, sociedades mais coesas emergiram no Ocidente europeu, e as diferenças entre reformistas e conservadores não colocaram em risco as hierarquias sociais. Pelo contrário, da mesma forma como sucedeu no primeiro pós-guerra, os impulsos mais radicais de mudanças foram contidos, cedendo espaço para os esforços de reformulação do liberalismo econômico, a despeito da permanência de clivagens políticas e conflitos de classe. No entanto, se no entreguerras a estabilidade político-econômica esteve constantemente ameaçada, após a Segunda Guerra, novas condições favoreceram o refreamento dos conflitos sociais: descrédito da extrema-direita e do nacionalismo conservador; o trauma de uma guerra que vitimara uma quantidade muito maior de civis do que a anterior, dificultando o espaço para outro recrudescimento de sentimentos militaristas; esquerda mais flexível que, após ter acumulado o desapontamento do fracasso dos ímpetos revolucionários dos anos 1918-1923, havia se tornado mais disposta às cooperações com outras forças políticas; e, por fim, a emergência de novos partidos confessionais de centro, fiadores de arranjos políticos de "cooperação" ${ }^{72}$

Outra transformação ocorrida no segundo pós-guerra foi a disposição pela interferência nos assuntos externos por parte das duas grandes potências que protagonizaram a Guerra Fria. O Plano Marshall, ao qual já nos referimos, foi um dos elementos que influenciaram a política e a economia dos países europeus ocidentais em favor da reconstrução liberal. Simultaneamente, porém, as diferentes formas de pressão da política soviética resultaram, como efeito colateral, no fortalecimento do consenso entre diferentes setores políticos que, em reação ao comunismo, estabeleceram as bases do Estado de Bem-Estar Social. O sucesso desse modelo de Estado justificou-se pela sua capacidade de deitar normas para a disputa político-partidária, fundadas sobre uma economia estável, sem desafios à hierarquia social, com altos índices de

\footnotetext{
${ }^{71}$ MILWARD, Alan S. The reconstruction of Western Europe, 1945-51. London: Methuen, 1984, p. 19-22.

${ }^{72}$ MAIER, op. cit., p. 154-160.
} 
produtividade, cujos critérios de desempenho justificavam-se pela enorme capacidade de produção e distribuição de bens. ${ }^{73}$

No novo contexto do "compromisso" forjado após a Segunda Guerra, produto de décadas de ajustes que criaram as condições favoráveis ao novo cenário, presume-se que era forçoso às forças da velha tradição socialista-reformista readequar seu discurso para dar coesão político-ideológica às suas agendas. Essa coesão foi buscada tanto no campo interno quanto no externo, de forma que a recusa definitiva ao ataque às estruturas do capitalismo não se traduzisse, ao menos do ponto de vista ideológico, em uma aceitação das premissas do liberalismo econômico.

\subsection{As definições do socialismo democrático no segundo pós-guerra}

Um importante aspecto para a análise da social-democracia no segundo pós-guerra refere-se a sua postura diante do reconhecido prestígio assumido pelo movimento comunista internacional após o sucesso militar da União Soviética na frente oriental. O sacrifício de dezenas de milhões de soviéticos redimiu os comunistas dos pactos de não-agressão e partilha, firmados entre Stálin e Hitler, antes de 1941. Até que a Alemanha declarasse guerra à União Soviética, o alinhamento quase automático dos Partidos Comunistas ocidentais a Moscou e sua passividade diante do agressor custaram-lhes a retaliação oficial e a pecha de antipatrióticos. A situação mudou quando Stálin mobilizou o Exército Vermelho para a "grande guerra patriótica”, mas não a ponto de eliminar a ampla desconfiança - correta na maioria das vezes de que, em qualquer parte do mundo, os comunistas subordinavam-se estritamente aos interesses da política internacional soviética. ${ }^{74}$ Mais importante aqui, contudo, é reconhecer que, após o conflito, os partidos da velha tradição social-democrata gozaram de maior prestígio nos países que não foram ocupados pelo inimigo - Grã-Bretanha e Suécia (neutra na guerra); nos países onde a resistência foi desprezível - Dinamarca e Noruega; ou naqueles cujos governos no exílio submeteram-se a Londres - Bélgica e Holanda. O mesmo não se aplica àqueles países em que a resistência à ocupação nazista contou com a liderança dos comunistas. ${ }^{75}$

\footnotetext{
${ }^{73}$ Ibidem, p. 161; FEINSTEIN; op. cit., p. 187.

${ }^{74}$ Excetua-se o clandestino Partido Comunista Italiano, que não seguiu a linha da União Soviética. Na perspectiva da política externa stalinista, até 1941, a guerra representava um conflito inter-imperialista e não antifascista. No campo de concentração de Dachau, o que restou dos comunistas alemães também condenou as diretrizes de Moscou. Cf. SASSOON, op. cit., p. 85.

${ }^{75}$ SASSOON, op. cit., p. 94.
} 
É o caso de França e Itália, onde os socialistas foram ofuscados pelos Partidos Comunistas mesmo quando estes foram alijados dos pactos de reconstrução nacional, no momento em que a Guerra Fria impôs demarcações ideológicas mais claras. ${ }^{76}$ O Partido Socialista Italiano ainda experimentaria um surpreendente sucesso nas eleições para a Assembleia Constituinte de 1946, ficando à frente do Partido Comunista por uma diferença não tão expressiva de votos, feito que jamais voltaria a se repetir. Já o Partido Socialista da França chegou ao poder por um breve período logo após a guerra (1946-1947). Em 1947, os socialistas franceses expulsaram os comunistas do governo de reconstrução, buscando uma aliança com forças de centro. A estratégia, contudo, não garantiu a preservação do Partido Socialista como força política proeminente na França, e os socialistas levariam até a década de 1970 para voltar a ser eleitoralmente competitivos. Há ainda o caso especial da Finlândia, onde os comunistas alcançaram grande prestígio ao término da guerra, mas, sob os auspícios de uma cautelosa União Soviética, contiveram seus impulsos diante da possibilidade real de chegada ao poder. Terminariam perdendo espaço ao longo dos anos para a centro-esquerda, à medida em que ela cativava boa parte do eleitorado, alertando-o para o que seriam os malefícios das transformações radicais e do alinhamento com o vizinho soviético. ${ }^{77}$ As divergências entre socialistas e comunistas se avolumariam rápida e decisivamente entre 1945 e 1951, tendo como fator fundamental de cisão as considerações em torno da política das duas grandes potências mundiais. Nesse curto período, as circunstâncias em que se fundamentaram tal embate moldaram permanentemente a identidade do socialismo democrático do pós-guerra.

Entre 1945 e 1946, um Labour Party bastante otimista se esforçaria para unificar os socialistas europeus, promovendo reuniões que incluíam a presença de seus pares do Leste. Estes, no entanto, ao apoiarem o estreitamento de relações com a União Soviética, minaram os planos dos britânicos de refundar uma Internacional Socialista forte e unida. ${ }^{78}$ Contudo, seria o ano de 1947 o mais decisivo para as clivagens da esquerda, data a que simbolicamente se atribui o início da Guerra Fria nos seus termos definitivos. Após a morte de Franklin Roosevelt e ascensão de Harry Truman à presidência dos Estados Unidos, em março, é formalmente anunciada a Doutrina Truman e, três meses depois, o Plano Marshall. A formulação do plano

\footnotetext{
${ }^{76}$ Poder-se-ia acrescentar aqui, os casos da Iugoslávia e da Grécia, onde as lutas de libertação combinaram-se com revolução social. Mas tanto estes países, quanto aqueles que foram tragados à esfera de influência soviética no Leste europeu, não apresentariam muita possibilidade de atuação para os socialistas a não ser, no caso destes últimos, nos primeiros anos do pós-guerra.

77 SASSOON, op. cit., p. 107-108.

${ }^{78}$ OWEN, David. O caso da Inglaterra: quais as mudanças ocorridas? Que futuro? In: A social-democracia alemã e o trabalhismo inglês. Cadernos da UnB. Brasília: UnB, 1982, p. 5-6.
} 
contou com o apoio do ministro das Relações Exteriores do Reino Unido, o trabalhista e exsindicalista Ernest Bevin. Em setembro, pressentindo o isolamento, Stálin responde com a criação do Cominform, reedição sovietizada da Internacional Comunista. Esse instrumento subordinado à política externa soviética contaria com a adesão dos Partidos Comunistas francês e italiano como únicos partidos-membros da Europa ocidental, aprofundando em seus respectivos países a relação de desconfiança entre comunistas e socialistas, outrora aliados na Resistência. Na verdade, a unidade entre os dois grupos manter-se-ia por algum tempo - e não sem conflitos - entre os italianos, até que os socialistas, por força de sua ala moderada, fossem atraídos pelo pragmatismo do bloco liderado pela democracia-cristã. ${ }^{79} \mathrm{Na}$ França, a ruptura foi quase imediata, com os comunistas condenados à marginalização política diante do poderoso bloco de poder dominante, ainda que permanecessem gozando de grande apoio popular. No Reino Unido, um fragilizado Partido Comunista passaria a fazer débil oposição ao governo trabalhista. $^{80}$

Em 1948, já desfalcados pelo "cisma do leste", os social-democratas europeus reuniramse na Conferência da Internacional Socialista a fim de definir o conceito de democracia pelo qual iriam combinar seus esforços. Na ocasião, graças à influência soviética, consolidava-se no Leste europeu as chamadas democracias populares. Lideravam-nas os Partidos Comunistas, exitosos em fagocitar as demais organizações até que alcançassem estabelecer o regime de partido único. Portanto, a diferenciação com a estratégia e a propaganda comunista era não só desejada pelos socialistas como também representava uma necessidade de posicionamento no espectro político. Se não lhes era possível esquivar-se do clima imposto pela Guerra Fria, era ao menos viável - e legitimador - apresentar-se como uma "terceira via". É o que se constata no documento produzido na Conferência, quando, ao lado da defesa de reformas socializantes, pregavam-se direitos consagradores da tradição liberal, como o reconhecimento da preeminência do indivíduo, o pluripartidarismo e o fortalecimento da justiça eleitoral. Deve-se ressaltar, contudo, que mesmo a busca pelo que se considerou aqui a "terceira via", não impediu, por exemplo, que o Partido Trabalhista Britânico fosse favorável à assinatura do Tratado de Defesa do Atlântico Norte, que originou a Organização do Tratado do Atlântico

\footnotetext{
${ }^{79} \mathrm{O}$ distanciamento definitivo entre socialistas e comunistas na Itália se daria a partir da divulgação do "Relatório Secreto" por Kruschev, em 1956. Antes disso, porém, o Partido Socialista e o Partido Comunista chegaram a travar discussões em torno da proposta de unificação dos partidos. Essa possibilidade era reforçada pelo fato de a maioria dos socialistas italianos não serem tão avessos à União Soviética àquela altura. Ver MAGRI, Lucio. $O$ alfaiate de Ulm: uma possível história do Partido Comunista Italiano. Tradução de Silvia De Bernardinis. São Paulo: Boitempo, 2014, p. 129-138.
}

${ }^{80}$ OWEN, op. cit., p. 7. 
Norte (OTAN), pacto assinado em 4 de abril de 1949 - incluindo-se aí a sua ala esquerda, a exemplo de demais partidos social-democratas europeus igualmente signatários. ${ }^{81}$

Finalmente, o movimento mais conciso no sentido de dar identidade ao socialismo democrático europeu ocorreu no Congresso de Frankfurt (I Congresso da Internacional Socialista), realizado em junho de 1951. Nele, produziu-se um documento mais preciso do que o de 1948, a Declaração de Frankfurt (Objetivos e Tarefas do Socialismo Democrático), contendo bases sólidas oriundas do acúmulo de experiência dos partidos signatários ao longo dos primeiros anos do pós-guerra. Devido a sua importância doutrinária para os partidos socialistas do mundo todo, e não só para os da Europa, convém a seguir analisar de perto algumas partes desse documento.

A declaração já inicia com uma denúncia pouco moderada do sistema capitalista, enxergando apenas no socialismo a possibilidade de sua necessária superação. Os sujeitos a quem se credita essa tarefa, no entanto, não se restringem ao operariado. À ideia de um "sujeito revolucionário" contrapõe-se a visão de cidadãos sensíveis à causa socialista, algo que contrasta em termos teóricos com os programas das Internacionais fundadas no século XIX. Vejamos:

Do século XIX em diante, o capitalismo tem desenvolvido enormemente as forças produtivas. Isso tem sido feito às custas da exclusão da grande maioria dos cidadãos da possibilidade de decidir sobre a produção. Colocou-se os direitos de propriedade antes dos direitos dos homens. Criou-se uma nova classe de assalariados sem propriedades ou direitos sociais. Isso reforçou a luta entre as classes. (...). Por que os assalariados sofreram mais do capitalismo, o socialismo se desenvolveu primeiro como um movimento de assalariados. Desde então, mais e mais cidadãos estão compreendendo que o socialismo interessa a todos os homens que acreditam que a exploração do homem pelo homem precisa ser abolida. ${ }^{82}$

Percebe-se, portanto, a combinação de metas de reforma estrutural da sociedade com um projeto histórico de cidadania que, enfim, conciliasse o desenvolvimento econômico com direitos sociais. Adiante, o documento faz apologia do Estado intervencionista e do planejamento, conceito que, como vimos, estava em voga no vocabulário dos policy makers de todos os espectros políticos. Para os socialistas reunidos em Frankfurt, no entanto, parecia que a ideia de planificação da economia correspondia a um estágio inexorável do desenvolvimento histórico, e que, querendo-se ou não, a anarquia da produção capitalista haveria de dar lugar ao

\footnotetext{
${ }^{81}$ Ibidem, p. 8.

${ }^{82}$ I Congress of the Socialist International, Frankfurt. Aims and tasks of democratic socialism. Disponível em: <http://www.socialistinternational.org/viewArticle.cfm?ArticleID=39>
} 
que seria uma racionalidade superior, exclusiva do socialismo democrático. Eis talvez o produto mais bem-acabado do já mencionado casamento do intervencionismo econômico com o ideário da esquerda:

O socialismo se tornou uma das principais forças nos assuntos internacionais. Ele tem passado da propaganda à prática. Em alguns países, os fundamentos de uma sociedade socialista já foram lançados. (...). Os princípios do socialismo estão provando seu valor na ação. (...). Em muitos países o capitalismo descontrolado está cedendo lugar a uma economia em que a intervenção estatal e a propriedade coletiva limitam o terreno de capitalistas privados. Mais pessoas estão reconhecendo a necessidade do planejamento. Seguridade social, liberdade sindical e democracia industrial estão ganhando espaço. $^{83}$

Também as diferenças dos socialistas com o movimento comunista internacional encontram sua demarcação mais definida na Declaração de Frankfurt. Antes, atribui-se o alegado atraso da realização do socialismo à divisão presente no movimento internacional dos trabalhadores, cuja responsabilidade recairia sobre o bolchevismo. O comunismo não faria mais que tentar se apropriar falsamente da tradição pertencente ao socialismo, "construindo uma rígida teologia incompatível com o espírito crítico do marxismo". ${ }^{84}$ Aguçando a crítica, o documento considera o movimento comunista o instrumento de um novo imperialismo, que se vale da ditadura de partido único, da burocracia militar, do terror policial e mesmo do trabalho forçado para sustentar uma nova classe de privilegiados. Em contraposição, o socialismo é apresentado como um movimento que não requer rígida uniformidade de ação:

Quer os socialistas construam sua fé no marxismo ou em outro método de analisar a sociedade, quer eles sejam inspirados por princípios religiosos ou humanitários, todos eles batalham pelo mesmo objetivo: um sistema de justiça social, melhoria de vida, liberdade e paz mundial. (...) Diferente do totalitarismo, o socialismo não impõe ao povo um papel de passividade. Ao contrário, ele não pode ser bem-sucedido sem uma profunda e ativa participação do povo. É a democracia na sua forma mais elevada. ${ }^{85}$

Embora o documento tenha vindo a público em 1951, nele estão os elementos que vinham moldando o ideário socialista desde o final da guerra. Assim, as considerações feitas até aqui em torno da Declaração não são relevantes apenas por constituírem uma síntese do tal ideário, mas também porque estarão presentes com maior ou menor nitidez nas linhas fundamentais do pensamento socialista brasileiro a partir de 1945.

\footnotetext{
${ }^{83}$ Idem.

${ }^{84}$ Idem.

${ }^{85}$ Idem.
} 
No próximo item realizaremos uma rápida análise do desenvolvimento do Estado de Bem-Estar Social no Reino Unido. Esse esboço dará uma visão geral da efetiva passagem dos social-democratas às funções de coarquitetos de um modelo de Estado que vigoraria por mais de trinta anos na Europa.

\subsection{0 início do fim do socialismo democrático no Reino Unido: do "Relatório Beveridge" ao Welfare State}

Inegavelmente, o conceito de Welfare State tornou-se fortemente associado ao governo do Labour Party no pós-guerra. Porém, como vimos, as ideias e práticas do bem-estar social não foram originadas em nenhuma parte do movimento socialista europeu. A novidade era que, quando a derrota do fascismo já se anunciava, as diversas forças políticas do campo vencedor perceberam a necessidade de ir além das políticas sociais implementadas até então. Às necessidades colocadas pelo advento da sociedade industrial de massas somaram-se aquelas explicitadas pela exaustão social após três décadas de sucessivas catástrofes.

O grande passo no sentido da criação do Welfare State no Reino Unido foi dado a partir da publicação do Relatório Beveridge (Report on Social Insurance and Allied Services), que atingiria grande prestígio e projeção ao influenciar policy makers de diversas nações. Encomendado em 1941 pelo governo de coalização, chefiado pelo primeiro-ministro conservador Winston Churchill, o relatório fazia parte de um esforço de guerra que compreendia a necessidade de assegurar um nível aceitável de padrão de vida para a população e conter o conflito entre as classes. Ao antever futuros desequilíbrios sociais ao término do conflito mundial, a reforma do National Insurance Act, vigente desde 1911, tornou-se um ponto fundamental na agenda do governo. A lei a ser reformada era de autoria do governo liberal (1906-1915), e previa seguro em caso de doença e desemprego com recursos provenientes do fundo de contribuição de empregados e empregadores. ${ }^{86}$

Durante dezessete meses, o economista William Beveridge liderou os trabalhos do Committee on Social Insurance and Allied Services, designado para vistoriar a situação da saúde e da seguridade social existentes, e fazer recomendações em torno do tema. O relatório final, apresentado em novembro de 1942, propunha a contribuição do trabalhador economicamente ativo a um seguro nacional que beneficiasse adoentados, desempregados, aposentados e viúvas,

\footnotetext{
${ }^{86}$ Cf. CARDOSO, Fábio Luiz Lopes. A influência do Relatório Beveridge nas origens do Welfare State (19421950). Revista Todavia, Ano 1, n. 1, jul. 2010, p. 39-53.
} 
como forma de proporcionar-lhes um padrão mínimo de garantia de vida. ${ }^{87}$ Além de figurar como um marco na história político-econômica moderna, a importância do documento pode ser medida também por seu alcance popular: cerca de 800 mil pessoas compraram seus exemplares, tornando-o um best-seller, feito pouco comum em publicação dessa natureza. ${ }^{88}$

$\mathrm{Na}$ visão de Clive Jenkins, importante líder sindical e membro do Labour Party, o relatório consistiu em uma resposta do governo à pressão provocada pelo aparecimento de elementos favoráveis ao fascismo nas fileiras do conservadorismo britânico, em meio ao clima de instabilidades provocado pelo sucesso inicial das investidas militares dos alemães. ${ }^{89}$ Segundo a interpretação consagrada do cientista social Richard Timuss, convém realçar o fato de que o governo em questão era de coalizão, e que ele arcava com uma guerra total sem precedentes, dois fatores que o pressionavam a adotar uma nova atitude face à "questão social". Essas motivações explicariam a ampla aceitação, pelo menos momentânea, do desvio - por seus tradicionais proponentes - das cartilhas conservadora e liberal. Na avaliação de Timuss, no entanto, o que mais importou para a mudança de atitude foi a crescente manifestação generalizada de privações sociais, a tal ponto que o governo central consentia, pela primeira vez na história, a necessidade de uma profunda reconstrução societária. Subsequentemente, as vacilantes reformas iniciadas, ainda na vigência da guerra, eram o prelúdio para a introdução do Welfare State por uma administração trabalhista bem menos inibida em relação às suas próprias ações. ${ }^{90}$

Para Paul Addison, autor de um dos mais abrangentes estudos sobre a política britânica durante a Segunda Guerra, a influência dos ministros trabalhistas que se somaram ao governo de coalizão deu ao subsequente governo trabalhista traços de maior reformismo. De qualquer forma, já nas eleições gerais de 1945, todos os principais partidos britânicos comprometeramse com os princípios da reconstrução política e econômica endossados por seus respectivos líderes em tempos de guerra. Assim, diferentemente do período de grandes hostilidades entre os partidos no entre-guerras, a nova disputa se travava já sob o consenso estabelecido quanto à

\footnotetext{
${ }^{87}$ ADDISON, Paul. The road to 1945: British Politics and the Second World War. London: Quartet, 1977, p. 169170.

${ }^{88}$ SASSOON, op. cit., p. 141.

${ }^{89}$ JENKINS, Clive. O Estado de bem-estar: objetivos, realizações e deficiências. Cadernos da UnB, op. cit., p. 163.

${ }^{90}$ TIMUSS, Richard. Problems of social policy. Official civil history of the Second World War. London: 1950, Apud JEFFERYS, Kevin. British politics and social policy during the Second World War. The Historical Journal, vol. 30, n. 1, 1987, p. 123.
} 
necessidade de políticas sociais de grande alcance. ${ }^{91} \mathrm{E}$ ainda que um governo liderado pelo ícone conservador Winston Churchill tivesse apresentado sua própria versão do Relatório Beveridge, dando início à aprovação de leis no Parlamento, foram os trabalhistas do Labour Party que se mostraram diante da população como os mais compromissados com a implementação e o aprofundamento das reformas sociais. $\mathrm{E}$ isto foi o que lhes rendeu a expressiva vitória eleitoral de $1945 .^{92}$ Para se ter uma ideia da euforia e das esperanças suscitadas após a divulgação do resultado do pleito, é ilustrativo destacar um trecho do editorial “A vitória do povo", do Daily Herald, periódico então de grande circulação e historicamente simpático aos trabalhistas:

O desempenho do povo britânico na eleição geral de 1945 merece figurar na história ao lado das suas mais poderosas realizações. (...) [O povo] tem proclamado a sua vontade e a sua política com tal ênfase que irá tocar os amantes da liberdade e da justiça social em toda a Terra, e que irá se estabelecer para sempre como um grande ato de liderança na construção da paz. ${ }^{93}$

De fato, como veremos no capítulo seguinte, a euforia alcançou também o Brasil, onde teria tocado "amantes da liberdade e da justiça social". Mais do que uma transição eleitoral, a vitória trabalhista e seu plano de governo refletiam genuinamente uma longa escalada ao poder, alicerçada sobre um suporte popular que se acumulara no decorrer das décadas precedentes. ${ }^{94}$ É de se indagar, portanto, se esse momento de maturidade não simbolizava acima de tudo o começo da definitiva acomodação da classe trabalhadora organizada à democracia liberal, ainda que reformulada. Nesse caso, é justo afirmar que, para efeito da manutenção de sua influência ideológica sobre trabalhadores e intelectuais dentro e fora do Reino Unido, os trabalhistas teriam muito a provar quanto a sua capacidade de gerir um Estado em reconstrução.

Assumindo o governo, os trabalhistas se depararam com o desafio de montar uma estrutura que, para priorizar reformas sociais (o que viria a ser o próprio Welfare State), contasse com o necessário suporte de uma economia altamente produtiva. No retrovisor, persistia a imagem da depressão dos anos 1930, a recordar-lhes os limites de confiar a tarefa ao setor

\footnotetext{
${ }^{91}$ ADDISON, op. cit., p. 180 e 275-278.

92 Ver manifesto trabalhista de 1945 dirigido à população britânica no Anexo 1.

93 Daily Herald, 27.07.1945 apud FIELDINGS, Steven. What did 'the people' want?: the meaning of the 1945 general election. The Historical Journal, Vol. 35, n. 3, 09/1992.

94 WILLIAMS, Francis. Fifty years march: The Rise of the Labour Party. London: Odhams, 1951, p. 358. Apud FIELDINGS, Steven. What did 'the people' want?: the meaning of the 1945 general election. The Historical Journal, Vol. 35, n. 3, 09/1992, p. 623-639.
} 
privado. Por sua vez, o modelo do New Deal, com seu sistema de salários elevados, era impraticável em qualquer lugar da Europa no pós-guerra. Assim, os trabalhistas assumiram para si a necessidade de o Estado controlar setores-chave da economia, mediante uma política de gradual nacionalização. O criterioso plano resultante dessa proposta alcançou elevado apoio na sociedade britânica, uma vez que o setor privado consentiu com a proposta de uma racionalização do sistema de economia privada pela via do Estado, cuja eficiência de suas empresas deveria incentivar o restante da economia suprindo bens e serviços com custos reduzidos. ${ }^{95}$

Durante os anos em que esteve no poder, entre 1945 e 1951, o Labour Party não teve dificuldades para aprovar a nacionalização do Banco da Inglaterra, de empresas mineradoras, ferrovias e rodovias de longa distância. Quando ofereceu resistência, a oposição conservadora e liberal não foi capaz de impedir a encampação de usinas e distribuidoras elétricas e de gás, embora tenha impedido que o mesmo ocorresse com a indústria siderúrgica.

No entanto, os trabalhistas demonstraram uma enorme incapacidade de formular políticas para o setor privado da economia e de levar às consequências práticas os seus postulados teóricos que previam o estabelecimento do que chamavam de "democracia industrial”. Por esse conceito, entendia-se que os sindicatos funcionariam também como protagonistas no gerenciamento da economia global, indo além da tradicional atuação de pressão contra os patrões. Contudo, como explica Donald Sassoon, uma vez aproximando-se do poder o Labour Party não demonstrou carregar constrangimentos diante do dilema que sempre afetara as fileiras socialistas, no qual se pressupunha que reformar o capitalismo - e melhorar as condições de vida da população - seria ao mesmo tempo legitimá-lo e adiar sua eventual superação. ${ }^{96}$

Sobre os alicerces das nacionalizações, os trabalhistas criaram seu esquema de Welfare tal como esperado por seus seguidores, respondendo a um novo momento histórico: uma força de trabalho integrada a uma economia de volta à prosperidade, capaz de ascensão social e despreocupada quanto ao sistema de saúde e de aposentadoria; um serviço de transporte e uma estrutura educacional eficientes; e ainda a provisão de suprimentos essenciais, como gás e eletricidade, a baixos custos. O Welfare State, enquanto elevava o nível de vida da classe trabalhadora, simultaneamente estabilizava o sistema de propriedade privada do ponto de vista

\footnotetext{
95 SASSOON, op. cit., p. 151.

${ }^{96}$ Ibidem, p. 138 e 152-153.
} 
econômico, social e político. As reformas coincidiram com um novo período histórico de incremento de produtividade para a economia britânica, em um cenário de relativa tranquilidade social. O sucesso do Welfare State deu razão aos apelos anteriormente dirigidos por William Beveridge aos conservadores, quando estes ainda se mostravam relutantes em acreditar que as instituições de bem-estar pudessem tornar a indústria britânica ainda mais competitiva. É verdade que, já em 1951, os trabalhistas perderiam a nova disputa do governo para os conservadores, mesmo tendo obtido maior votação.

De qualquer forma, as transformações societárias se mostraram duradouras, pelo menos até que a crise econômica do início da década de 1970 impusesse uma batalha por um novo consenso. Até então, o Reino Unido viveu o coroamento do consenso que ficou popularmente conhecido como "butskellismo", expressão oriunda da junção dos nomes de dois dos mais influentes líderes políticos britânicos: Rab Butler, do Partido Conservador, e Hugh Gaitskel, do Partido Trabalhista.

O caso britânico poder-se-ia inserir em um esquema mais amplo, o que Charles Maier chamou de "contrato social do pós-guerra", cuja característica fundamental foi o lugar assumido pelo movimento sindical que se encontrava cindido entre "comunistas" e "moderados". O isolamento dos primeiros nas principais esferas sindicais permitiu aos "moderados" perseguir uma atuação que apostava mais nos frutos do crescimento econômico, do crescimento dos salários e das políticas de bem-estar do que em drásticas medidas redistributivas. ${ }^{97}$

O próximo capítulo fará uma análise do surgimento do Partido Socialista Brasileiro, privilegiando as formas como o agrupamento buscou refletir a conjuntura nacional e internacional no imediato pós-Segunda Guerra. Analisaremos principalmente as primeiras tentativas de assimilação de elementos advindos da tradição do socialismo democrático europeu e dos novos rumos que o Reino Unido tomava sob o governo trabalhista, observados com entusiasmo por seus congêneres brasileiros. ${ }^{98}$

\footnotetext{
${ }^{97}$ MAIER, Charles. The postwar social contract: comment. International Labor and Working-Class History, $\mathrm{n}$. 50, 1996, p. 148, apud COLISTETE, Renato P. Productivity, wages, and labor politics in Brazil, s1945-1962. Journal of Economic History, v.67, n.1, 03/2007, p. 93-94.

${ }^{98}$ Apesar de Getúlio Vargas ter criado no Brasil o Partido Trabalhista Brasileiro (PTB), assume-se aqui que este não pertencia ao mesmo "filo" histórico do Partido Trabalhista Britânico. Já quanto ao Partido Socialista Brasileiro, acredita-se que há razões evidentes para identificá-lo com aquela tradição. Outros critérios têm levado alguns historiadores a defenderem que o PTB, após a morte de Vargas, teria caminhado para o modelo trabalhista britânico. Ver, por exemplo, FERREIRA, Jorge. João Goulart: uma biografia. Rio de Janeiro: Civilização Brasileira, 2011.
} 
De forma complementar, avaliaremos também os rumos subsequentes do PSB de modo a obtermos uma visão de conjunto da trajetória do partido, o que será útil para os capítulos posteriores. 


\section{Capítulo II - A trajetória dos socialistas brasileiros entre 1945 e 1965}

O Brasil não passaria incólume às novas expectativas introduzidas pelo socialismo democrático após o fim da Segunda Grande Guerra. A nova fase experimentada pelo Labour Party tenderia a ser supervalorizada por velhas e novas gerações de socialistas que, por um lado, opunham-se ao Estado Novo e suas reminiscências e, por outro, recusavam o modelo soviético de partido e sociedade. ${ }^{99}$ Adotando inicialmente o nome de Esquerda Democrática, a partir de um açodado processo de arregimentação de forças, o PSB se tornaria no Brasil um dos grupos políticos mais interessados em divulgar as inovações e impasses do trabalhismo britânico. Nas páginas dos dois principais órgãos da imprensa socialista, o Folha Socialista e o Vanguarda Socialista, os socialistas brasileiros atualizavam, em curto intervalo temporal, o que lhes pareciam ser os desdobramentos de uma nova etapa mundial de expansão da democracia que, para os otimistas, sedimentaria as condições para a entrada decisiva dos trabalhadores na luta por direitos e para a socialização dos meios de produção.

Entretanto, para o PSB, se o sucesso momentâneo dos pares europeus sugeria que daquele momento em diante abria-se a perspectiva de um quadro sociopolítico mais promissor, a realidade brasileira, inversamente, não ofereceria terreno fértil para a disseminação das ideias socialistas democráticas, principalmente ao se levar em conta a inexistência no país de uma tradição política a elas correspondente com capacidade de galvanizar amplo suporte de adeptos. Para suprir essa lacuna, os passos iniciais do partido foram marcados pela investida em uma propaganda otimista, prevendo o triunfo do seu programa como um desdobramento quase lógico da reintrodução da democracia no Brasil.

Para a concretização desse auspicioso futuro, a propaganda e a intervenção dos socialistas brasileiros na cena pública buscariam identificar os adversários de uma "democracia genuína". Tais adversários não se restringiam apenas aos variados defensores da herança estadonovista e aos comunistas - na medida em estes últimos capitalizavam para si o sucesso dos soviéticos nos campos de batalha. Além destes, havia também os atores que, em alguma medida, advogavam o liberalismo, e de quem os socialistas foram aliados durante a luta contra o Estado Novo. Desde o princípio, a Esquerda Democrática fez questão de demarcar seu espaço, deixando clara sua concepção de que não mais se poderia deixar confundir o conceito de

\footnotetext{
${ }^{99}$ Cf. HECKER, Alexandre. Socialismo sociável: história da Esquerda Democrática em São Paulo. São Paulo: UNESP, 1998, p. 47. É o autor que destaca a supervalorização do exemplo britânico.
} 
democracia com os preceitos do liberalismo econômico - embora assumisse a validade de princípios herdados do ideário humanista-liberal clássico. Nada diferente do que se poderia esperar de um agrupamento que se assumia socialista e democrático no contexto do segundo pós-guerra. Afinal, como vimos no capítulo anterior, sobretudo no que se refere aos desdobramentos da política britânica, o socialismo democrático fortaleceu-se sob a prerrogativa de que a democracia liberal fracassara diante das demandas dos novos tempos, mostrando-se incapaz de absorver as demandas cada vez mais intensas - e não mais negligenciáveis - de ampliação dos direitos das classes historicamente subalternas.

Considerando a formação socioeconômica brasileira - claramente distinta daquelas resultantes do desenvolvimento do capitalismo europeu - e a falta de uma consistente trajetória prévia do socialismo democrático no Brasil, compreende-se que o PSB, tão logo arregimentado, encontraria adiante uma série de dificuldades para consolidar suas ideias e depurar as ambiguidades de sua própria militância. Neste capítulo, analisaremos as fases do PSB durante toda a sua trajetória - 1945-1965 - dando ênfase à etapa inicial do imediato pós-guerra, momento em que o partido mais absorvia e buscava sintetizar os influxos ideológicos externos. O exame das fases subsequentes também se faz oportuno, tendo em vista a importância de contextualizar as primeiras ideias dos socialistas brasileiros no conjunto de seus desdobramentos ao longo da década de 1950 e início dos anos 1960, o que auxiliará na avaliação do legado do PSB e sua relação com propostas de reforma e de bem-estar social.

$\mathrm{Na}$ vasta historiografia que se desenvolveu em torno da experiência democrática de 1945 a 1964, bem como na literatura que, no campo da ciência política, buscou tratar do sistema de representação partidária nesse período, observa-se o espaço reduzido que é destinado a considerações sobre o PSB. Tanto nos estudos sobre a esfera institucional quanto nas análises que privilegiam a relação desta com as bases sociais, a ênfase costuma ser depositada em atores que expressaram as tendências políticas mais nítidas, circunscritas ao processo que levou ao golpe militar de $1964 .{ }^{100}$ Dada essa preocupação teórica e metodológica que tem orientado os estudos sobre o regime de 1945-1964, há razões óbvias para a relativa ausência do PSB. O partido ocupou um espaço pequeno para que pudesse influenciar a agenda política do país ou determinar os rumos do movimento sindical no período. Durante os quase vinte anos em

\footnotetext{
${ }^{100}$ Há uma enormidade de trabalhos que de algum modo têm o período de 1945 a 1964 como recorte temporal e que buscam a partir dele interpretar o golpe militar. Poder-se-ia citar, como exemplo, duas coletâneas cujos autores assumem perspectivas bastante distintas: TOLEDO, Caio Navarro (Org.). 1964: visões críticas do golpe. Democracia e reformas no populismo. Campinas (SP): Unicamp, 1997; e FERREIRA, Jorge (Org.). O populismo e sua história: debate e crítica. Rio de Janeiro: Civilização Brasileira, 2001.
} 
questão, os socialistas forneceram pouco mais de duas dezenas de mandatos parlamentares no Congresso Nacional, enquanto que nos sindicatos prevaleceu uma clara hegemonia de trabalhistas e comunistas.

Há, contudo, três trabalhos que, ao escolher o PSB como objeto central de análise, representaram um resgate mais completo da história do partido. $\mathrm{O}$ primeiro deles é a tese de doutoramento de Silvio Frank Alem, "Contribuição à história da esquerda brasileira: o Partido Socialista Brasileiro (1945-1964)", defendida em 1988. Com esta obra que inaugurou os estudos sobre o PSB, o autor tinha como objetivo expresso preencher a lacuna representada pela ausência do partido na historiografia da esquerda e do pensamento político brasileiro. Os outros dois trabalhos foram publicados em datas próximas, durante meados da década de 1990. Tratase dos livros "Semeando a democracia: a trajetória do socialismo democrático no Brasil" de Miracy Gustin e Margarida Vieira, publicado em 1995; e "Socialismo sociável: história da Esquerda Democrática em São Paulo (1945-1965)” de Alexandre Hecker, publicado em 1998. O primeiro está composto em duas partes que separam a contribuição de cada autora, tendo ambas o objetivo de buscar identificar as ambiguidades do projeto histórico do PSB e o lugar do partido no complexo esquema ideológico em que se movia a política brasileira no interregno entre duas ditaduras. Já o trabalho de Hecker preocupa-se, principalmente, com um resgate das ideias e da militância dos socialistas paulistas, grupo que mais se destacou na formulação teórica do PSB, contrapondo suas diferenças com outros interlocutores da época.

Acompanhando a historiografia recente sobre o PSB, é possível distinguir três fases que sintetizam a orientação do partido entre 1945 e 1965: (i) primeira fase de luta pela democratização, com os socialistas ainda dispersos; aglutinação de forças fundamentada na negação do varguismo, do comunismo soviético e do liberalismo; e busca não tão exitosa de coesão partidária (1945-1950); (ii) sobreposição de uma orientação tática com vistas à obtenção de resultados eleitorais mais favoráveis; flerte com o populismo e descaracterização identitária a partir do apoio dado a Jânio Quadros em São Paulo; e início do processo de adesão ao nacionalismo reformista (1950-1960); (iii) radicalização à esquerda; incorporação do partido às lutas pelas reformas de base; consolidação da aliança com os trabalhistas; e dispersão após o golpe civil-militar (1960-1965).

As seções a seguir abordarão as principais tendências partidárias de cada uma dessas fases. 


\subsection{Da formação da Esquerda Democrática às eleições de 1950}

Os primeiros contornos da militância socialista no Brasil na década de 1940 se desenvolveram no confronto com a ditadura do Estado Novo, particularmente no seu fim, quando uma série de setores da sociedade passou a pressionar pelo restabelecimento das liberdades democráticas. Nesse contexto é que foi criada a Esquerda Democrática, em meados de 1945, e que dois anos mais tarde adotaria o nome definitivo de Partido Socialista Brasileiro (PSB) - sem que a mudança de nome respondesse a substanciais alterações programáticas. Apresentando, inicialmente, uma estrutura de frente de esquerda, e não de um partido político convencional, a Esquerda Democrática congregou um grupo heterogêneo de indivíduos identificados com a possibilidade de associar a luta por democracia com reformas sociais que inserissem na política institucional a maioria da população. Segundo Antonio Candido de Mello e Souza, um dos intelectuais do grupo original de São Paulo, a Esquerda Democrática "se formou como entidade própria a partir de liberais socializantes que não se ajeitaram na UDN, cristãos progressistas, alguns simpatizantes comunistas de periferia e socialistas independentes". ${ }^{101}$

A consolidação da Esquerda Democrática no mapa político brasileiro foi facilitada pela campanha eleitoral do candidato da União Democrática Nacional (UDN) à presidência da República, o brigadeiro Eduardo Gomes. Além de incorporar a Esquerda Democrática, a chapa encabeçada pela UDN reuniu ainda o Partido Libertador (PL) e o Partido Republicano (PR) os quatro partidos juntos formando o que se chamou "Oposição Coligada". O aspecto mais relevante da candidatura de Eduardo Gomes foi que ela se tornou o centro de gravitação dos distintos grupos que se opunham ao Estado Novo. ${ }^{102}$ Nas eleições de dezembro de 1945, os socialistas lançaram seus candidatos próprios à Assembleia Constituinte de 1946 pela legenda da UDN. Porém, a vinculação da Esquerda Democrática com a UDN não significou mais que um acordo programático e eleitoral. Nos seus primeiros anos de atuação, a UDN tinha o caráter de uma grande frente eleitoral, enquanto que os componentes da Esquerda Democrática preferiram manter sua entidade independente e sustentar uma plataforma própria. ${ }^{103} \mathrm{~A}$ candidatura de Eduardo Gomes entusiasmou os socialistas, sendo possível dizer que ela não

\footnotetext{
${ }^{101}$ CANDIDO, Antonio. Informe político. In: CALIL, Carlos Augusto; MACHADO, Maria Teresa (Orgs.). Paulo Emílio. Um intelectual na linha de frente. São Paulo: Cia das Letras, 1993, p. 66.

102 BENEVIDES, Maria Victoria. A UDN e o udenismo: ambiguidades do liberalismo brasileiro (1945-1965). Rio de Janeiro: Paz e Terra, 1981, p. 42.

${ }^{103}$ HECKER, op. cit., p. 70. Para uma análise abrangente da formação da UDN e do comportamento dos socialistas diante dela, ver BENEVIDES, op. cit., Capítulo 1, itens 2.2 e 4.
} 
somente os aproximou do restante das forças oposicionistas, como também teve a importância de permitir o encontro dos diversos perfis identificados acima por Antonio Candido. ${ }^{104}$

Dessa forma, esses diversos perfis, muitos deles agrupados em pequenas organizações formadas ainda no fim do Estado Novo, mantiveram a Esquerda Democrática unida mesmo após a derrota de Eduardo Gomes para o representante da situação, o general Eurico Dutra, do Partido Social Democrático (PSD). Na verdade, as considerações sobre o futuro da Esquerda Democrática foram iniciadas por seus membros ainda durante a campanha, quando, a fim de dar total prioridade a esta última, julgou-se conveniente adiar a discussão acerca da configuração que o novo partido deveria assumir. ${ }^{105}$ Ressalta-se, ainda, que a lei eleitoral elaborada em maio de 1945 pela ditadura de Getúlio Vargas tornou inviável o registro de partidos estaduais e regionais ou de partidos muito pequenos. Dessa forma, conforme observou Edgard Carone, incorporar-se à Esquerda Democrática representou uma alternativa de sobrevivência para pequenos agrupamentos de esquerda. ${ }^{106}$

Em aspectos fundamentais, o surgimento da Esquerda Democrática nem de longe assemelhou-se com o longo processo de formação dos partidos socialistas democráticos europeus. Estes nasceram do interior do próprio movimento operário, acumulando uma vasta experiência prática, como foi mostrado no Capítulo I. A Esquerda Democrática, por sua vez, conforme adverte Silvio Alem, nasceu "comitê eleitoral" ou, ainda, como "agregação ideológica". ${ }^{107}$ Essa constatação pode ser comprovada em parte pela própria imprensa socialista nos primeiros anos após a ditadura varguista, na qual não se encontram referências formais a nenhuma das tradições socialistas brasileiras dos tempos anteriores à redemocratização, embora seja possível reconhecer que tais tradições foram introduzidas de forma fragmentada na Esquerda Democrática.

Não obstante, a diferença observada acima não constituiu um impeditivo para que os socialistas brasileiros buscassem partilhar as mesmas expectativas e preceitos que consideravam comuns aos social-democratas europeus no pós-guerra. À sua maneira, o

\footnotetext{
104 “...o elemento catalizador da Esquerda Democrática, no seu começo, é a indicação de Eduardo Gomes para candidato à Presidência da República...”. CARONE, Edgard. Movimento operário no Brasil (1945-1964). São Paulo: Difel, 1981, v. 2, p. XV.

${ }^{105}$ O parlamento futuro, queira ou não queira o ditador, terá função constituinte. Diário de Notícias, 23.08.1945, p. 7.

${ }^{106}$ CARONE, op. cit., p. XV.

${ }^{107}$ ALEM, op. cit., p. 21.
} 
socialismo democrático brasileiro realizou leituras bastante criativas acerca da conjuntura nacional e internacional, o que se refletiu, por exemplo, nos objetivos traçados para a superação de sua defasagem em relação aos congêneres da Europa. O insucesso de tais objetivos não retira a originalidade dos intelectuais do PSB. Entretanto, é justo levantar a questão de quanto o otimismo inicial desses atores com relação à evolução do socialismo democrático europeu prevaleceu sobre uma perspectiva mais realista dos limites que o novo regime político brasileiro colocaria à atuação de um agrupamento que pretendia caminhar naquele mesmo sentido. Limites que seriam manifestados tão logo o governo Dutra adotasse uma ação repressora contra qualquer eventual manifestação autônoma dos trabalhadores.

No livro "O Socialismo", publicado em 1954 por Dante Costa, um dos fundadores da Esquerda Democrática, o autor afirma que somente com o surgimento do agrupamento é que “o socialismo fez no Brasil o seu surgimento não fictício”. Mais adiante, Dante Costa afirma que "a história do socialismo se confunde (...) no Brasil com a história do Partido Socialista Brasileiro". ${ }^{108}$ Contudo, ao analisar a formação da Esquerda Democrática em São Paulo, Alexandre Hecker argumenta ser possível conjecturar certos vínculos entre os socialistas paulistas os socialistas reformistas atuantes na Primeira República. Entre estes últimos, figuraram nomes como Antonio Piccarolo e Hermínio Sachetta, influenciadores de alguns dos mais destacados integrantes do PSB de São Paulo - tais como Paulo Emílio Salles Gomes, Antonio Candido, Fúlvio Abramo e Plinio Gomes de Mello. ${ }^{109}$

Por sua vez, tendo por base uma série de entrevistas a vários militantes que tomaram parte na formação do partido, Miracy Gustin lança uma suposição:

O partido seria a síntese de movimentos políticos anteriores que se pensava estarem completamente extintos. Indivíduos e grupos permaneceram, porém, e levaram para o PSB as ideias anteriores. Configurava-se, então, a ideia de que a ação coletiva que se estruturara no partido era fruto de 'áreas de igualdade' que foram se constituindo ao longo de variadas lutas, com diversificado ideário. Um modo absolutamente sincrético de construção. Uma totalidade complexa que ainda não se conseguira compreender bem. ${ }^{110}$

Independentemente de uma classificação dos socialismos existentes previamente no Brasil e de sua relação com a Esquerda Democrática, é certo que o esgotamento de uma

\footnotetext{
${ }^{108}$ COSTA, Dante. O Socialismo. Rio de Janeiro: Organizações Simões, 1954, p. 86.

${ }^{109}$ HECKER, op. cit., p. 62 e 68.

${ }^{110}$ GUSTIN, Miracy B. S. Ideologia e política: a trajetória do socialismo democrático como racionalidade políticopartidária no Brasil, p. 23. In: GUSTIN, Miracy B. S.; VIEIRA, Margarida L. M. (Orgs.). Semeando a democracia: a trajetória do socialismo democrático no Brasil. Contagem (MG): Palesa, 1995.
} 
ditadura, que logrou suprimir por algum tempo seus opositores, fez com que se anunciasse um novo e promissor cenário, assim como o término da Segunda Guerra fez brotar novas esperanças em escala planetária. Para os socialistas, assim como para outros setores políticos, os dois movimentos relacionavam-se intimamente. Após três décadas de sucessivas catástrofes, não poderia haver nada mais justificável do que aspirar avanços democráticos nas diversas áreas da vida social. Em uma situação um pouco parecida com a luta contra o fascismo na Europa que reuniu forças políticas variadas -, a Esquerda Democrática nasceu em 1945 como uma genuína ala esquerda do movimento democrático que teve na UDN sua principal articuladora.

Como abordado no capítulo anterior, em quase todo o mundo o processo de distanciamento entre comunistas e socialistas culminou em uma irremediável clivagem das esquerdas durante a reconstrução do pós-guerra. Mas a ruptura definitiva no movimento operário internacional não ocorreu imediatamente após o conflito mundial, embora o início dos embates remonte às vésperas da Primeira Guerra. ${ }^{111} \mathrm{O}$ fim da aliança das esquerdas na segunda metade dos anos 1940 foi parte tanto das escolhas de influentes partidos de base popular quanto das tensões produzidas pelo advento da Guerra Fria. No Brasil, como em qualquer outro país tomado em particular, esse processo teve componentes especificamente nacionais.

Antes que o movimento queremista tomasse as ruas em favor da continuidade de Getúlio Vargas no poder, os socialistas da Esquerda Democrática de São Paulo foram ao encontro de Luís Carlos Prestes, recém-libertado nos estertores do Estado Novo. Os socialistas confiavam, então, na possibilidade de atrair os comunistas para a frente de oposição ao ditador. A essa altura o Partido Comunista Brasileiro (PCB) ainda não havia levado a público sua linha política de defender uma "Constituinte com Getúlio" - o que não tardaria a ocorrer. De qualquer forma, o esforço dos socialistas de nada adiantou, porque o "Cavaleiro da Esperança" já estava resolutamente decidido a não fazer coro com os oposicionistas, caracterizados por ele como reacionários. $^{112}$

$\mathrm{Na}$ verdade, a decisão de Prestes começou a ganhar corpo com a realização da Conferência da Mantiqueira, em 1943, ocasião em que o PCB iniciava sua reestruturação após anos de esfacelamento resultante de perseguições, confinamentos e exílios. Prevalecendo as teses do grupo de militantes que se aproximavam de Prestes - elevado então ao posto de secretário-geral do PCB - concebeu-se que o governo Vargas, ao declarar guerra ao eixo,

\footnotetext{
${ }^{111}$ Ver SASSOON, op. cit., capítulo 4.

${ }^{112}$ Cf. HECKER, op. cit., p. 66-67.
} 
alinhou-se às forças democráticas em luta contra o fascismo. Consequentemente, os comunistas justificaram que à classe operária e seus sindicatos caberia tomar parte em uma ampla unidade com os setores considerados progressistas da sociedade contra os elementos reacionários internos e externos. ${ }^{113}$ Dessa forma, os comunistas delinearam a versão brasileira da orientação geral assumida pela quase totalidade do movimento comunista internacional, orientação que ficou conhecida pelo nome de "união nacional" (ou "unidade nacional"). ${ }^{114}$

Embora os comunistas experimentassem uma espetacular ascensão a partir de 1945, no movimento estudantil, uma das consequências do direcionamento adotado pelo PCB foi o descrédito do partido junto a uma geração que protagonizou intensas lutas contra o Estado Novo. Bem relacionado nos meios universitários, Domingos Vellasco, uma das iminentes lideranças da Esquerda Democrática, desferiu duras críticas aos pronunciamentos de Prestes, com afirmações de que, inversamente aos objetivos que propalava, a posição do líder comunista "teria rompido a unidade nacional em torno da luta contra o fascismo, na qual os estudantes estiveram inclusos". Durante o período de mobilização pela redemocratização e de agitações em torno da candidatura de Eduardo Gomes à Presidência da República, registrou-se uma crescente adesão estudantil à Esquerda Democrática, mas também e principalmente à UDN. ${ }^{115}$

Desde então, socialistas e comunistas mantiveram-se em polos políticos opostos, fazendo com que já se manifestasse no Brasil a ruptura definitiva ainda não consumada na Europa. Independentemente do encontro frustrado dos paulistas com Prestes, a totalidade da Esquerda Democrática buscou desde o início - ao menos no nível teórico - uma clara diferenciação com o comunismo soviético. E é provável que boa parte dos elementos da Esquerda Democrática se sentisse mais confortável mantendo-se distante de qualquer compromisso tático com o PCB, menos por questões de convicção pessoal do que pelo receio

\footnotetext{
${ }^{113}$ Ver documentos produzidos pelo PCB nesse período em CARONE, Edgard. O PCB: 1943 a 1964. v. 2. São Paulo: Difel, 1982, Primeira Parte, Item A. Francisco Weffort destaca que, para além da confluência de interesses políticos, a aproximação do PCB ao cambaleante governo Vargas teria se efetivado mediante um acordo que conduziria os comunistas à legalidade em troca do apoio ao ditador. Ver WEFFORT, Francisco. "Origens do sindicalismo populista no Brasil’". Estudos CEBRAP, n. 4, 04-06.1973, p. 76-77.

114 Distintas versões latino-americanas da linha de "união nacional" surgiram por esse mesmo período. Em especial, o caso do PC da Argentina se diferenciou bastante do PCB. Naquele país, os comunistas caracterizaram o governo de Juan Domingo Perón como fascista e, em seguida, tomaram parte na União Democrática, uma coalizão de forças oposicionistas. Ver CODOVILLA, Vitorio. "Os comunistas argentinos e o peronismo" In: LÖWY, Michael. O marxismo na América Latina. Uma antologia de 1909 aos dias atuais. 2.ed. São Paulo: Perseu Abramo, 2006, p. 172-174.

115 MATTOS, André Luiz R. R. Uma história da UNE (1945-1964). Campinas (SP): Pontes, 2014, p. 37-39.
} 
de sofrer pressão por parte dos setores mais conservadores da sociedade - em especial, os setores da classe média em disputa.

Terminada a guerra, o anticomunismo no Brasil se lançaria novamente em uma cruzada, tão mais agressiva quanto maior fossem as simpatias angariadas pelo PCB entre as populações urbanas. Nesse cenário, a presença da Esquerda Democrática na frente de oposição de 1945 foi explorada por uma afiada propaganda anticomunista por parte dos situacionistas do PSD. Os pessedistas encontraram aí uma brecha para tentar compensar a apatia perante às massas de seu candidato à Presidência. Pois até a reta final da campanha, quando Vargas finalmente declarou seu apoio a Dutra, o candidato da UDN era tido como favorito ao pleito. Em meio ao temor da derrota, os adversários de Eduardo Gomes rechearam as páginas dos jornais com denúncias contra o que seria um plano conjunto da Esquerda Democrática com o PCB para a "sovietização" do Brasil. Apelando ao eleitorado católico, o PSD alegava que a Esquerda Democrática era tão comunista quanto o PCB, mas que disfarçava isso "repudiando esta ou aquela linha para ocultar ser contra a família e a propriedade". ${ }^{116}$

Em resposta aos ataques, a Esquerda Democrática não se furtaria em recorrer igualmente a referências a preceitos católicos e a condenações ao PCB. O embate nos jornais prosseguiu, com os socialistas declarando que "a Esquerda Democrática, chefiada pelo católico praticante e impoluto Domingos Vellasco, está desferindo golpes mortais contra o 'prestismo' e o 'fiuzismo"". ${ }^{117} \mathrm{O}$ curioso, nesse caso, é que a resposta dos socialistas, no calor da disputa eleitoral, não demonstrou qualquer empenho para fugir à estreiteza da polarização ideológica tal como colocada pelo adversário.

De acordo com Alexandre Hecker, havia uma diferença fundamental entre as estratégias de comunistas e socialistas no Brasil: enquanto os primeiros apostavam no fortalecimento do Estado dentro de sua concepção etapista - premência da revolução democrático-burguesa - os segundos concebiam o fortalecimento da sociedade civil e sua inserção nas disputas

\footnotetext{
${ }^{116}$ O voto dos católicos. Folha da Manhã, 22.11.1945, p. 11. O Partido da Representação Popular (integralista), por sua vez, ao manifestar em nota seu apoio a Dutra, apontou como incoerente da parte do candidato adversário, Eduardo Gomes, que se declarava conservador e católico praticante, estar aliado "da pior farsa comunista, dos intelectuais internacionalistas da Esquerda Democrática". Segundo a nota, para não trair seus aliados, Gomes teria de governar com eles e, assim, faria um "governo vermelho no Brasil". Nosso candidato à Presidência da República. Folha da Manhã, 25.11.1945, p. 23.

117 A Esquerda Democrática.... Folha da Manhã, 29/11/1945, p. 20. A expressão "fiuzismo" é uma referência a Iedo Fiúza, candidato lançado por Prestes à disputa presidencial de 1945 pela sigla do PCB. Trata-se de uma expressão claramente exagerada, uma vez que Fiúza não desempenhou qualquer papel mais relevante na política brasileira e tampouco pertenceu às fileiras do partido de Prestes.
} 
institucionais já como tarefas da construção do socialismo. ${ }^{118}$ Daí a permanente luta da Esquerda Democrática por liberdades sindicais e de associação, combinada à crítica a todas as formas de caudilhismo, paternalismo e populismo, vistos como entraves à plena participação popular no processo político.

Mais do que uma demarcação ideológica, a crítica da Esquerda Democrática a heranças políticas tidas como personalistas, teve outro papel importante para a construção do partido. Como este não tinha uma concepção homogênea sobre o socialismo, a identificação dos "adversários" se prestou a dar alguma coesão partidária que orientasse um caminho a se seguir. Como ressalta Miracy Gustin, nessa fase inicial de atuação, o combate aos personalismos de Prestes e Getúlio, a quem "eram atribuídos poderes extraordinários”, teria se tornado "recursos simbólicos defensivos utilizados no período com o objetivo de prevenir uma desagregação partidária irremediável". ${ }^{119}$

O eixo Rio de Janeiro-São Paulo era absolutamente hegemônico dentro da Esquerda Democrática, mas as diferenças entre os dois polos dessa hegemonia perdurariam durante todo o percurso do PSB, até que o golpe civil-militar de 1964 pusesse termo abrupto às divergências. ${ }^{120}$ Enquanto o núcleo embrionário do PSB no Rio de Janeiro reunia políticos experimentados de tradição liberal, como João Mangabeira, Hermes Lima e Domingos Vellasco, o núcleo paulista foi marcado pelos embates da esquerda partidária e estudantil nos anos precedentes. A esse último agrupamento lhe faltava a experiência parlamentar, mas a presença de muitos quadros teóricos conferiu-lhe o papel de responsável por sistematizar a unidade teórica dos socialistas. ${ }^{121}$ Assim, na I Convenção Nacional da Esquerda Democrática, realizada no Rio de Janeiro em abril de 1946, os paulistas tiveram papel preponderante na definição do novo programa que balizaria a atuação do PSB. A Convenção levou à superação dos organismos provisórios e à adoção de uma estrutura partidária mais definida, embora a proposta de mudança de nome para Partido Socialista, pleiteada pelos paulistas, tenha sido temporariamente derrotada. ${ }^{122}$

\footnotetext{
${ }^{118}$ HECKER, op. cit., p. 59-60.

${ }^{119}$ GUSTIN, op. cit., p. 50.

${ }^{120}$ GUSTIN, op. cit., p. 54.

${ }^{121}$ HECKER, op. cit., p. 74-75.

${ }^{122}$ Mantida em plenário a denominação Esquerda Democrática. Folha da Manhã, 11.04.1946, p. 6; e Episódios ocorridos na convenção da Esquerda Democrática. Folha da Manhã, 12.04.1946, p. 11.
} 
Dentro da pluralidade que marcou a formação da Esquerda Democrática, havia espaço para outros grupos "marginais" igualmente radicais, se comparados às feições liberais da direção nacional. É o caso do grupo de Mario Pedrosa, organizado em torno do jornal Vanguarda Socialista, baseado no Rio de Janeiro. Na verdade, somente em 1948 o grupo se somaria ao PSB. Antes disso, porém, o Vanguarda deixou registrado em seu jornal um recorrente diálogo com os futuros correligionários, sempre acreditando na necessidade de se estabelecer o que considerava um "genuíno" Partido Socialista no Brasil. ${ }^{123}$

Mario Pedrosa e seus companheiros não refutavam por completo a experiência da União Soviética, alimentando a esperança de que naquele país uma outra sociedade mais democrática pudesse surgir a partir de um movimento interno de contestação à burocracia estatal. $\mathrm{O}$ Vanguarda Socialista parecia estar seguro de que "do campo da social-democracia emergiria uma forte tendência revolucionária que superaria o velho reformismo e estabeleceria novas bases para a luta pelo socialismo", de maneira que, por toda a parte, inclusive na União Soviética, o comunismo seria desbancado por uma nova consciência socialista e democrática. O modelo de partido reivindicado pelo grupo como o mais capaz de atender a essas aspirações seria o do Labour Party, pois, segundo o Vanguarda, ele teria se formado organicamente ao lado das lutas da própria classe trabalhadora britânica, e não por cima dos interesses desta. Assim, Pedrosa considerava a chegada dos trabalhistas ao poder no Reino Unido como a abertura da oportunidade para o socialismo, a menos que uma crise mundial detivesse sua marcha. ${ }^{124}$

Ao se definir como um partido que se impunha a luta pela consciência dos trabalhadores antes da luta pelo Estado, a Esquerda Democrática também definia o espaço urbano-industrial como o lugar principal para a sua propaganda. Isso significava disputar a fatia do eleitorado já cativado pelo Partido Trabalhista Brasileiro (PTB) e pelo PCB, partidos mais estruturados e bem mais eficientes eleitoralmente que os socialistas. ${ }^{125}$ Encontrando sempre limites à sua expansão, o PSB seria muito mais reconhecido pela qualidade intelectual de sua militância e pela intransigência dos seus princípios programáticos do que pela sua capacidade de

\footnotetext{
${ }^{123}$ Ver por exemplo: Já será o Partido Socialista? Vanguarda Socialista, n. 34, 19.04.1946, p. 1. Em ocasião da I Convenção da Esquerda Democrática, o jornal faz uma polêmica com o agrupamento acerca de qual seria o tipo de organização e o programa mais adequados à realidade brasileira.

${ }^{124}$ Cf. ALEM, Silvio Frank. Contribuição à história da esquerda brasileira: o Partido Socialista Brasileiro (19451964). Tese de doutoramento. São Paulo: FFLCH/USP, 1998, p. 71-72. Para as caracterizações do Vanguarda Socialista sobre a conjuntura internacional ao fim da Segunda Guerra, a União Soviética e o Labour Party, ver: Vanguarda, partido e socialismo. Vanguarda Socialista, n. 50, 09.08.1946, p. 1 e 4.

${ }^{125}$ GUSTIN, op. cit., p. 55-56; e HECKER, op. cit., p. 89.
} 
mobilização. Dessa maneira, construindo um mapa do cenário político-partidário brasileiro em 1948, um articulista do Jornal do Brasil dá-se conta de haver "também o Partido Socialista Brasileiro (antiga Esquerda Democrática), que tem um programa definido e conta com representantes de grande projeção cultural, mas que, em verdade, dispõe muito mais de massa cinzenta do que de massa eleitoral". ${ }^{126}$

Com relação ao comportamento da Esquerda Democrática em face da UDN, Alexandre Hecker sugere que, já em 1945, os socialistas tinham nítida percepção das ambiguidades dos seus aliados circunstanciais. Assim, para a Esquerda Democrática, apesar dos anseios antiautoritários manifestados com ardor na luta contra o varguismo, a UDN não estaria disposta a levar muito adiante o processo de democratização, abandonando as bandeiras democráticas tão logo elas entrassem em rota de colisão com os "privilégios da elite econômica". ${ }^{127} \mathrm{O}$ autor não deixa claro, porém, se essa percepção se restringe ao grupo socialista de São Paulo, seu objeto principal de análise, ou se também seria válida para o restante da organização. Nesse último caso, ao analisar-se a lista dos 63 signatários do manifesto inaugural da Esquerda Democrática, distingue-se um bom número de indivíduos que jamais se vincularam organicamente ao partido, além de outros tantos que migraram para legendas mais identificadas com as elites econômicas - casos de Juracy Magalhães, Arnon de Mello, Chagas Freitas, Jurandir Pires Ferreira, dentre outros. ${ }^{128}$

O que nos parece certo é que, de fato, havia um núcleo original bem-estruturado na Esquerda Democrática que tinha em mente construir um partido de esquerda já em meados 1945, embora o conteúdo de seu programa não estivesse muito claro naquele momento. Esse núcleo original, formado sobretudo por líderes mais destacados do Rio de Janeiro - mas contando logo com a adesão dos socialistas de São Paulo - prevaleceu sobre indivíduos dispersos ou mesmo setores "menos ideológicos" que se vincularam à Esquerda Democrática quando esta se formou. Esses indivíduos certamente encontrariam lugares que lhes parecessem mais atraentes para desenvolver sua atuação política, prescindindo de um projeto político que primava por um estrito respeito a um programa e por alguma disciplina partidária.

\footnotetext{
126 Visão panorâmica da política brasileira. Jornal do Brasil, 05.06.1948.

${ }^{127}$ HECKER, op. cit., p. 71.

${ }^{128}$ Ver relação dos fundadores da Esquerda Democrática no Anexo 2.
} 
De qualquer forma, o "Manifesto da Esquerda Democrática" ao apresentar à população (e ao eleitorado) o novo agrupamento é categórico quanto às perspectivas com as quais os socialistas pretendiam prosseguir na luta democrática:

Forma de convívio político, seria absurdo confundir a democracia com determinada ordem econômica. Não foram os postulados da democracia que motivaram a crise do nosso tempo, pois não são próprias dela nem as desigualdades sociais, nem os antagonismos de interesses entre as classes. Desigualdades e antagonismo decorrem, isto sim, do liberalismo econômico que pleiteamos transformar, em nome do mesmo ideal democrático. ${ }^{129}$

O documento, datado de 25 de agosto de 1945, foi veiculado apenas três meses depois da divulgação do decreto que restabeleceu as eleições - Decreto-Lei n. ${ }^{\circ}$ 7.586, de 28 de maio de 1945, a célebre "Lei Agamenon". Embora não houvesse garantias de que as eleições se realizariam dentro do prazo esperado pela oposição, certamente os membros da Esquerda Democrática viram-se espremidos pelo tempo e pelas circunstâncias. Encontrando-se o grupo imerso quase que indistintamente dentro de uma ampla frente democrática, tornava-se premente à ala esquerda desta frente assumir corpo e alma próprios. Em um momento crucial da vida política brasileira, em que as posições assumidas tendiam a demarcar com maior clareza o espaço de cada ator (individual ou coletivo), é natural que homens e mulheres que partilhavam dos pressupostos lançados pela Esquerda Democrática buscassem aproveitar a oportunidade de apresentar-se de forma autônoma ao eleitorado. ${ }^{130}$ Contudo, o apressado processo de "agregação ideológica", de que fala Silvio Alem, fez emergir uma agremiação heterogênea e fragmentada, que porém não se mostrou indiferente a tal estado de coisas. Desde o início, os integrantes da Esquerda Democrática dedicaram-se à tarefa prioritária de elaborar um programa que lhes desse identidade e coesão. Tal prioridade se expressa logo nas primeiras linhas do manifesto inaugural:

O movimento político está exigindo da ESQUERDA DEMOCRÁTICA ampla definição dos seus objetivos e processos, tantos são os apelos que, de toda a parte do Brasil, ela recebe. Nestes termos, a ESQUERDA DEMOCRÁTICA julga oportuno afirmar e precisar as linhas ideológicas fundamentais de seu pensamento político, para completa homogeneidade de seus quadros. ${ }^{131}$

\footnotetext{
${ }^{129}$ Ver "Manifesto da Esquerda Democrática", disponível no Anexo 3.

${ }^{130}$ Como dito anteriormente, foi pela legenda da UDN que a Esquerda Democrática lançou os seus candidatos próprios ao pleito do 2 de dezembro de 1945. Assim, quando dizemos que os socialistas tiveram um tempo exíguo para preparar-se para as eleições, referimo-nos tão somente a apresentar-se como um coletivo dotado de propostas próprias. Os expedientes burocráticos para o devido registro partidário somente seriam realizados no ano seguinte.

${ }^{131}$ Manifesto da Esquerda Democrática (grifos do original).
} 
No mesmo documento é possível notar alguns sinais da ausência de um movimento socialista expressivo que desse suporte à ação partidária. É o próprio agrupamento quem trata de configurar, de forma bastante abrangente, o "perfil" do militante apto a engrossar suas fileiras:

\footnotetext{
A ESQUERDA DEMOCRÁTICA não tem uma concepção filosófica da vida nem credo religioso; reconhece a cada um o direito de seguir, nessa matéria, à sua própria consciência. Nela cabem, assim, pessoas de todas as crenças e das filosofias mais diversas.

Daí o nosso apelo a todos os democratas de esquerda. Que todos se congreguem na ESQUERDA DEMOCRÁTICA. Que se organizem, por todo o território nacional, comissões da ESQUERDA DEMOCRÁTICA. ${ }^{132}$
}

Democratas de esquerda que, no foro íntimo, tivessem reservado o direito de seguir a orientação religiosa ou filosófica com que melhor se identificassem. À definição abrangente, entretanto, somava-se um delimitador importante, que subordinava a militância partidária ao principal objetivo da Esquerda Democrática: a promoção de uma gradual e progressiva socialização dos meios de produção como manifestação da vontade da maioria da população, sem prejuízo dos fundamentos democráticos de representação política. ${ }^{133}$ Como apregoado pelo socialismo democrático internacional entendia-se que, somente com o socialismo, se completaria a obra da democracia, mas que, além disso, as condições para essa empreitada negavam qualquer tipo de dogmatismo estranho às normas da competição partidária estabelecida.

Abrangentes, difusas ou genéricas, o fato é que as demarcações inicias dos socialistas procuraram estabelecer um compromisso político mínimo que assegurasse a reunião dos indivíduos e núcleos de indivíduos atraídos pelo amálgama entre socialismo e democracia democracia que não se restringia apenas à luta por liberdades democráticas no contexto nacional, mas que se estendia à própria vida partidária interna. Entretanto, o esforço dispendido em nome da coesão identitária não foi capaz de dirimir as divergências internas: após as primeiras defecções, sobretudo daqueles que se sentiriam melhor acomodados nas hostes

\footnotetext{
${ }^{132}$ Ibidem, p. 407-8 (grifos do original).

${ }^{133}$ Ibidem, p. 404.
} 
liberais, o mapa interno da Esquerda Democrática seguiu fragmentado. ${ }^{134}$ Como veremos, o traço da heterogeneidade acompanharia o PSB ao longo de toda a sua existência.

Entre os movimentos iniciais para a criação da Esquerda Democrática e o primeiro teste das urnas em dezembro de 1945, a vitória do Labour Party nas eleições gerais do Reino Unido, realizadas em 5 de julho, serviu de grande incentivo para a manutenção da unidade dos socialistas. O engenheiro e jornalista Jurandir Pires Ferreira, que teria passagem curta pela Esquerda Democrática, relacionou essa vitória às aspirações democratizantes no Brasil, considerando-a motivo de regozijo e de incentivo para os que lutavam contra a ditadura de Vargas. ${ }^{135}$

Procurando caracterizar o que doravante seria a Esquerda Democrática, seu futuro secretário-geral, Domingos Vellasco, previa a transformação da agremiação "num grande partido popular de que carece o Brasil". Com entusiasmo semelhante ao de seu correligionário citado acima, e em consonância com os sentimentos de pluralismo que animavam os socialistas britânicos e brasileiros, Vellasco afirmou:

Não tendo nenhuma concepção própria do destino do mundo e do homem para impô-la a quem quer que seja, mas deixando a cada um o direito de seguir, nessa matéria a sua própria consciência - a ED pode abrigar, nos seus quadros, indivíduos de quaisquer convicções filosóficas ou religiosas, a exemplo de partidos similares que existem em todo o mundo, a exemplo do Partido Trabalhista Inglês. ${ }^{136}$

Além do tema do pluralismo, outro componente da "nova fase" do socialismo democrático internacional, o da construção de um conceito ampliado de cidadania, em detrimento da ideia de "sujeito revolucionário", estava também presente na Esquerda Democrática. A organização reconhecia como atores fundamentais de sua empreitada as classes assalariadas, identificando uma unidade de interesses entre classe média e operariado. Mas nessa aliança caberiam até mesmo indivíduos de outras classes, desde que sensibilizados pela pregação socialista. Assim, em um cartaz de apresentação da Esquerda Democrática, de 1945, utilizando um tom algo triunfalista, é possível observar novamente a referência à incipiente

\footnotetext{
${ }^{134}$ Houve também defecções à esquerda, como no caso do grupo identificado por Antonio Candido como dos "metalúrgicos negros" de São Paulo, descontentes com o excessivo ecletismo da Esquerda Democrática. CANDIDO apud HECKER, op. cit., p. 69.

${ }^{135}$ Repercussão da vitória trabalhista na Inglaterra. Diário de Notícias, 27.07.1945, p. 3.

${ }^{136}$ Processos violentos e corruptores estão sendo empregados com o fim de desvirtuar o voto. Diário de Notícias, 14.08.1945, p. 6.
} 
experiência britânica como inspiração para o lugar político reivindicado pelo agrupamento que surgia:

A situação política e social da ESQUERDA DEMOCRÁTICA é equivalente a do Partido Trabalhista Inglês. Este venceu nas urnas, assumiu o governo e está executando o seu programa socialista, porque a classe média, os operários e até grandes burgueses e milionários, de espírito esquerdista na Inglaterra, o apoiaram. Assim apoiam, no Brasil, os mesmos elementos a ESQUERDA DEMOCRÁTICA e esta vencerá; e as condições econômicas e sociais entre nós se transformarão, quando ela, no Governo, executar o seu programa. ${ }^{137}$

Às vésperas da I Convenção Nacional da Esquerda Democrática, o líder João Mangabeira reafirmou as afinidades de seu agrupamento com o Labour Party, principalmente quanto ao caráter heterogêneo da militância presente em ambas as organizações. Como exemplo, igualou as tendências moderadas e radicais da Esquerda Democrática com o que julgava ser a mesma distinção entre dois proeminentes trabalhistas britânicos: de um lado, o então prestigiado primeiro-ministro Clement Attlee - um conde da Coroa, testa-de-ferro pragmático que cultivara boas relações com Churchill - de outro, Harold Laski - marxista declarado que chegara a prever a violência revolucionária em caso do fracasso do reformismo, e que não poupava críticas ácidas aos conservadores. ${ }^{138}$ É interessante notar que logo em seguida às declarações de Mangabeira, um cético Gilberto Freyre, que por ocasião da I Convenção Nacional se afastaria da Esquerda Democrática, também se valeria da referência à esquerda britânica para expressar sua contrariedade aos rumos que o agrupamento tomava. Segundo o sociólogo, a exemplo do Fabianismo inglês do final do século XIX, ao caso brasileiro convinha pleitear um socialismo democrático na forma de corrente de opinião acima de interesses partidários, tal como se sucedera em torno da campanha de Eduardo Gomes. ${ }^{139}$

Se, de modo geral, a Esquerda Democrática inclinava-se para a aceitação da pluralidade dos matizes socialistas e liberal-socializantes, também não faltaram aqueles entre seus militantes que viam como intolerável a presença de marxistas no partido. Também nesse caso, sob um ponto de vista bem particular, tal julgamento buscava tecer similaridades com os pares britânicos. Com efeito, um editorial do Vanguarda Socialista, de 1949, refletindo o pensamento de determinado setor da direção nacional do PSB, alegava que ser marxista, trotskista ou

\footnotetext{
${ }^{137}$ ESQUERDA DEMOCRÁTICA. A Esquerda Democrática chama-se. In: FERREIRA, Jorge; REIS, Daniel Aarão (Orgs.). As esquerdas no Brasil: nacionalismo e reformismo radical. 1945-1964. Rio de Janeiro: Civilização Brasileira, 2007, v. 2, anexo foto-documental (grifos do original).

${ }^{138}$ Reúne-se amanhã em convenção nacional a E.D. Folha da Manhã, 06.04.1946, p. 12.

${ }^{139}$ Considerações do sr. Gilberto Freyre sobre a política brasileira. Folha da Manhã, 07.04.1946, p. 14.
} 
stalinista era incompatível com uma organização que decidira pelo socialismo, tal como o Partido Trabalhista Inglês. ${ }^{140}$

As referências ao trabalhismo inglês minguariam ao longo dos anos, uma vez que o PSB, já tendo se apresentado ao eleitorado e justificado sua existência, canalizaria seus esforços para arenas de disputa em que o pragmatismo tendia a sobrepor os exemplos extraídos da experiência internacional. Parece razoável especular que também o socialismo democrático europeu falhou ao não se confirmar como um modelo exportador de políticas, suficientemente capaz de ocupar seu espaço em um mundo bipolar e inspirar seus pares nas periferias mundiais. O problema é que o socialismo europeu já enfrentava suas próprias e profundas contradições tão logo chegou ao poder ou onde estivesse próximo de fazê-lo. Em se tratando de projeto civilizatório, a segunda metade do século XX demonstrou que qualquer tentativa de terceira via estaria efetivamente condenada ao esmagamento pelos polos da Guerra Fria. ${ }^{141}$

No caso específico do Labour Party, é provável que a Esquerda Democrática tenha feito uma leitura de certo modo precipitada da dimensão do poder concentrada nas mãos daquele partido, avaliando com pouco realismo as condições domésticas em que os trabalhistas britânicos atuavam. Para Donald Sassoon, mesmo que o eleitorado de 1945 tenha confiado as reformas do Welfare State ao Labour Party, não havia evidências de que tenha surgido uma demanda social baseada no coletivismo, no socialismo ou em qualquer coisa que apontasse para o aumento da participação do Estado na vida privada. ${ }^{142}$ Essa avaliação lança dúvidas quanto à possibilidade real do socialismo democrático ser capaz, àquela altura, de arrebanhar a maioria dos trabalhadores e colocá-la em movimento na direção de um novo projeto de sociedade, e isso nos países onde seus adeptos eram os mais numerosos.

Em uma determinada análise - aquela que busca reforçar os vínculos entre as políticas de bem-estar social e as ideias fornecidas pelo Labour Party e pelo socialismo democrático de modo geral - o Welfare State poderia ser entendido como a tipificação ótima (e possível) do projeto que os socialistas se propunham a realizar. Entretanto, após a divulgação do Relatório Beveridge, também os conservadores do partido Tory se mostraram comprometidos com as

\footnotetext{
${ }^{140}$ Problemas internos do partido. Vanguarda Socialista, 10.10.1949. Na data em que este número do Vanguarda Socialista circulou, o jornal não pertencia mais ao grupo de Mario Pedrosa, tendo passado já à condição de órgão central do PSB.

${ }^{141}$ Sobre a política dos partidos social-democratas na Europa do segundo pós-guerra, ver SASSOON, op. cit., p. $115-273$

${ }^{142}$ SASSOON, op. cit., p. 139.
} 
reformas. Em março de 1943, Churchill dirigiu-se à nação para anunciar que, após a guerra, o desemprego deveria ser abolido, a propriedade do Estado estendida e o serviço de seguridade social ampliado em todos os seus propósitos. ${ }^{143}$ Não seria inoportuno salientar, ainda, que tanto as premissas do Relatório Beveridge quanto as diretrizes keynesianas - vetores do Welfare State - estavam vinculados à herança liberal, não tendo os trabalhistas legitimidade para "monopolizá-los" como patrimônios do socialismo democrático.

Para todos os efeitos, porém, a Esquerda Democrática compreendia a si como a parte brasileira de um momento de inflexão na história universal. Se se entendia que as catástrofes provocadas pelo imperialismo, pela Grande Depressão e pelo fascismo, além do perigo do “totalitarismo soviético", clamavam pela hora e a vez do socialismo democrático, os socialistas brasileiros não desprezavam o peso das tradições oferecidas pelos europeus. Nesse sentido, no programa aprovado pela I Convenção Nacional da Esquerda Democrática, o partido afirmavase herdeiro tanto das tradições socialistas quanto da evolução histórica que apresentamos no primeiro capítulo:

Não temos nenhuma intenção de improvisar ou elaborar princípios e programas independentes da realidade objetiva tanto brasileira como internacional. (...) O Partido considera-se, ao mesmo tempo, resultado da experiência política e social dos últimos cem anos em todo o mundo e expressão particular das aspirações socialistas do povo brasileiro. ${ }^{144}$

Experimentado militante identificado com o marxismo, rompido com as tendências stalinistas e trotskistas, Febus Gikovate foi um ator fundamental na elaboração do programa da Esquerda Democrática aprovado na I Convenção Nacional. ${ }^{145} \mathrm{O}$ programa lista uma série de reivindicações imediatas, com destaque para a nacionalização de setores-chave da economia como "fontes e empresas de energia, transportes e indústrias extrativas consideradas fundamentais", além de "terras não exploradas ou cuja exploração não atende ao interesse público". O programa defendia, ademais, a gestão partilhada da produção por comissões de

\footnotetext{
${ }^{143}$ Ibidem, p. 139-140.

${ }^{144}$ Programa da Esquerda Democrática Apud HECKER, op. cit., p. 48.

145 Antonio Candido refere-se a Febus Gikovate como tendo sido "um excepcional socialista democrático". Gikovate juntou-se ao grupo embrionário da Esquerda Democrática em São Paulo através do amigo Azis Simão, impondo-se logo como teórico e militante destacado. Qualidades que também lhe valeram destaque no conjunto do PSB nacional e, mais tarde, lhe custariam a detenção por órgãos de repressão do regime militar. CANDIDO, Antonio. Recortes. São Paulo: Companhia das Letras, 1993, p. 182-184.
} 
trabalhadores, em uma versão própria do ideal de "democracia industrial” já em declínio no Reino Unido. ${ }^{146}$

Se o socialismo internacional continuava a produzir alguma síntese ideológica com certo grau de homogeneidade, a responsabilidade por formular planos de ação imediata recaía sobre políticos e policy makers envolvidos na disputa política cotidiana de seus países. Contudo, a Esquerda Democrática e, mais tarde, o PSB, não se viram afetados diretamente por essa situação, uma vez que a possibilidade de sua conversão em partido de governo só poderia realizar-se em um horizonte longínquo. Apesar disso, enquanto seus militantes atuassem em espaços de disputa como o parlamento, sindicatos, bairros e demais entidades da sociedade civil e no movimento social, o conteúdo socialista de sua doutrinação teria que responder, em maior ou menor grau, a questões de natureza específica da conjuntura imediata.

Na II Convenção Nacional da Esquerda Democrática, realizada em abril de 1947 no Rio de Janeiro, a organização adotou definitivamente o nome de Partido Socialista Brasileiro e decidiu pela manutenção do programa aprovado na convenção anterior. Doravante, até a campanha eleitoral de 1950, os socialistas concentraram-se principalmente nos objetivos de consolidar sua militância de acordo com o ideário partidário e de se afirmar no cenário político nacional. Os dois objetivos estavam intimamente ligados, pois, no fundo, colocava-se o problema de como atingir um sem prejuízo do outro. ${ }^{147}$ De um modo bastante genérico, o exmilitante socialista Orlando Gomes recordaria a divisão partidária no período como composta por dois grupos: os "puros", que perseguiam os ganhos do respeito ao programa; e aquele constituído por um setor minoritário que seguiria qualquer aliança se houvesse ganhos eleitorais para o partido. ${ }^{148}$

Além da divisão sumária apresentada acima, havia ainda divergências graves entre elementos anticlericais e a ala católica do partido, esta última tendo à frente a figura de Domingos Vellasco. ${ }^{149}$ Como vimos, as concepções cristãs de Vellasco foram um componente fundamental da sua candidatura em 1945, servindo como resposta à ofensiva anticomunista de seus adversários e como forma de aproximação ao eleitorado. Durante a II Convenção Nacional

\footnotetext{
${ }^{146}$ Programa do Partido Socialista Brasileiro, Apud GUSTIN; VIEIRA, op. cit., p. 409-412.

${ }^{147}$ ALEM, op. cit., p. 105.

${ }^{148}$ Depoimento de Orlando Gomes a Silvio Frank Alem. Ibidem, p. 107-108.

${ }^{149}$ GUSTIN, op. cit., p. 41.
} 
do PSB, a força do secretário-geral do partido se confirmaria quando, com apoio de sua ala, Vellasco conseguiu suprimir do programa aprovado a defesa do direito ao divórcio. ${ }^{150}$

Por outro lado, a preponderância teórica dos socialistas de São Paulo se faria valer novamente na IV Convenção Nacional do PSB, realizada em outubro 1949 no Rio de Janeiro. Àquela altura, o debate em torno da tolerância à presença de marxistas no partido acirrava-se, situação que certamente era agravada por pressões externas exercidas pelo conservadorismo de amplas correntes de opinião e de partidos políticos. Incomodado com o que chamou de posturas stalinistas por parte dos correligionários, que atacavam a ala esquerda do PSB, Febus Gikovate buscou dirimir as divergências com uma proposta conciliadora que definisse o que se queria dizer com "socialização dos meios de produção" - defendida até então de forma genérica pelo conjunto do partido. Aprovada dentre as resoluções finais, a proposta previa a socialização progressiva com base no cooperativismo, acompanhada da planificação econômica, sendo esta efetuada sob formas políticas descentralizadas que deveriam resultar no fortalecimento dos poderes legislativos. ${ }^{151}$

Com alguma segurança, é possível afirmar que o fator que levou o partido a experimentar alguma unidade nesse período foi sua adesão ao movimento em defesa da estatização da exploração do petróleo. Tratava-se, enfim, de uma questão emergente no debate político nacional que se conciliava com pressupostos socialistas e mobilizava diversos setores da sociedade, além de abrir as primeiras fissuras no consenso conservador forjado sob o governo Dutra. Como veremos no Capítulo 4, o PSB integrou-se imediatamente à campanha "O Petróleo é Nosso", lançada pela corrente nacionalista do exército, tornando-se o primeiro partido no Congresso a defender o monopólio estatal integral das atividades petrolíferas. Durante as gestões de Roberto Gusmão (1947-1948) e Rogê Ferreira (1949-1950), ambos membros do PSB, a UNE se somou à campanha e, de acordo com Miracy Gustin, passou a estimular as primeiras iniciativas para a constituição do movimento nacionalista dos anos 1950. ${ }^{152}$ Conforme assinalado por Silvio Alem, a posição apresentada pelos socialistas mostrouse coerente com a defesa que a direção nacional do PSB fazia da ação do governo trabalhista

\footnotetext{
${ }^{150}$ Partido Socialista Brasileiro. Diário de Notícias, 15.04.1947, p. 7.

${ }^{151}$ ALEM, op. cit., p. 108-110.

152 GUSTIN, op. cit., p. 62-63. Diz a autora na mesma passagem: “a Liga de Emancipação Nacional, surgida no início da década de 50 e cujo objetivo era se transformar em uma instituição coordenadora das várias facções e movimentos anti-imperialistas no Brasil, germe do movimento nacionalista que se segue, teve socialistas como idealizadores..."
} 
no Reino Unido, promovendo a estatização de setores da infraestrutura do país. ${ }^{153}$ No entanto, como em outros momentos, na campanha pelo monopólio estatal da exploração do petróleo, os socialistas mergulhariam em um debate interno sobre as diferentes concepções entre nacionalização, estatização e socialização.

Junto à problemática do programa e do perfil partidário, persistia o problema da divulgação ainda muito restrita das ideias socialistas e da sua pequena presença nas regiões distantes do centro político nacional. Com a aproximação da eleição presidencial de 1950, a combinação desses fatores levaria as discussões internas a uma nova situação de desconforto evidente, em que as pressões dos diferentes grupos do PSB tornariam insustentável o frágil compromisso que garantiu alguma unidade partidária durante os primeiros passos da organização.

\subsection{O PSB nos anos 1950: sincretismo e flerte com o populismo}

Em setembro de 1949, o PSB foi convidado a tomar parte no acordo interpartidário ao lado de PSD, UDN e PR, que pretendiam lançar um candidato comum à Presidência da República. No mês seguinte, durante a IV Convenção Nacional do PSB, além das questões programáticas discutidas na seção anterior, deliberou-se sobre as condições para alianças eleitorais. Ficou decidido o seguinte: o partido deveria indicar candidatos próprios aos cargos executivos quando houvesse possibilidade de êxito; inexistindo esta possibilidade, o partido deveria apoiar candidatos idôneos, comprometidos com a democracia; e, finalmente, caso não houvesse nenhuma das condições anteriores, o PSB deveria lançar candidato próprio, mesmo sem chances de vitória. ${ }^{154}$

Inaugurando o debate interno sobre a sucessão presidencial, os socialistas de São Paulo - novamente sob a liderança de Febus Gikovate - posicionaram-se inicialmente em defesa de uma candidatura própria como forma de preservar e apresentar sua identidade socialista em âmbito nacional. ${ }^{155}$ Mas de posse das orientações delineadas na IV Convenção, a Comissão Nacional do PSB, diversos setores do partido e seus simpatizantes começaram a ventilar o nome de Eduardo Gomes como candidato natural dos socialistas à Presidência. Essa orientação foi favorecida quando, nos meses finais de 1949, a UDN deu por rompidas as negociações em torno

\footnotetext{
${ }^{153}$ ALEM, op. cit., p. 114.

154 Ibidem, p. 115-116;

${ }^{155}$ HECKER, op. cit., p. 110.
} 
do "acordão" com os outros partidos, e quando o PTB anunciou Getúlio Vargas como seu candidato. ${ }^{156}$

A situação parecia ter se estabilizado nas fileiras do PSB, até que os integralistas do Partido de Representação Popular (PRP) passaram a apoiar a candidatura de Eduardo Gomes. Ao se consumar a aliança entre a UDN e o PRP, os socialistas reuniram-se na capital federal em nova Convenção Nacional para decidir que rumos tomar diante do novo cenário. Com a entrada dos integralistas na chapa da UDN, tornou-se quase consensual a impossibilidade de reeditar a "aliança democrática" de 1945. Nos acalorados debates que se seguiram, as importantes lideranças nacionais do PSB - como Hermes Lima, Domingos Vellasco e Osório Borba - definiram-se pela defesa do voto em branco, sendo vencidos pela esquerda do partido que defendeu a proposta de uma candidatura própria. ${ }^{157}$ Por fim, João Mangabeira foi alçado candidato a presidente pelo PSB, tendo como vice na chapa o presidente da Comissão Estadual de São Paulo, Alípio Correa Neto. Mesmo levando-se em conta que o PSB apresentou uma candidatura de protesto, ou de propaganda, o resultado eleitoral obtido pelo partido foi desastroso, com os candidatos socialistas contabilizando cerca de $0,1 \%$ do total de votos. Estes concentraram-se principalmente no Distrito Federal e em São Paulo, mais um sinal da pouca abrangência nacional da militância socialista. ${ }^{158}$ A partir de então, ganharia espaço entre a militância do partido a tese de que eram necessárias novas estratégias para alcançar uma maior eficácia eleitoral. ${ }^{159}$

A inflexão maior nesse sentido ocorreria em São Paulo, justamente onde o alegado "puritanismo" dos socialistas paulistas costumava se opor à Direção Nacional do PSB, geralmente menos afeita à disciplina programático-partidária. Os passos decisivos que mudariam radicalmente a trajetória do PSB paulista começaram a ser dados no final da década de 1940, quando as posições de seus representantes na Câmara Municipal da capital apresentaram proximidades com as posições defendidas pelo então vereador Jânio Quadros, filiado ao Partido Democrata Cristão (PDC). A identificação e o trabalho legislativo comum do

\footnotetext{
${ }^{156}$ ALEM, op. cit., p. 116.

${ }^{157}$ Ibidem, p. 116-117. Dentre a ala esquerda do PSB proponente da candidatura própria estavam Febus Gikovate e Mario Pedrosa.

158 João Mangabeira obteve 9.446 votos e Alípio Correa Neto 10.800. O total de votantes foi de 8.254.989. BRASIL, Estatísticas do Século XX. Rio de Janeiro: IBGE, 2003.

${ }^{159}$ GUSTIN, op. cit., p. 73-74; HECKER, op. cit., p. 152.
} 
PSB paulistano com a emergente liderança de Jânio resultou na aliança PDC-PSB para a disputa da prefeitura de São Paulo, em 1953.

Conforme Miracy Gustin, os socialistas justificaram sua participação na campanha eleitoral - que assumiu o nome "Movimento 22 de Março" em alusão à data do pleito - com o argumento de que, para se lutar contra o populismo de Adhemar de Barros, era necessária uma política de massas. Consequentemente, a figura eloquente de Jânio Quadros, chocando-se com a máquina estadual ademarista e pretendendo-se porta-voz da população periférica, abriria a oportunidade para o PSB ampliar sua pregação junto à classe assalariada paulistana que, assim como o espaço urbano, passava por um processo de franca expansão. ${ }^{160}$

Ainda com relação à aproximação dos socialistas com Jânio Quadros, Alexandre Hecker acrescenta a hipótese de que tenha sido uma resposta de parte dos paulistas às investidas de cooptação do PTB e do próprio Vargas em direção à cúpula do PSB na capital federal. Mesmo que tênues e inconclusas, estas investidas teriam exercido mais pressão para que o PSB desse menos peso à fidelidade aos princípios em relação a possíveis leques de aliança política mais amplos. ${ }^{161}$ Já segundo Silvio Alem, o momento coincidiu com a mudança de orientação no discurso de Getúlio Vargas que, junto à "ala ideológica" em formação no PTB, assumia um tom mais nacionalista e lograva capturar os espaços pretendidos pelo PSB. Assim, enquanto os socialistas ainda amargavam a votação irrisória na eleição presidencial, os trabalhistas começaram a se definir mais claramente no mapa político brasileiro a partir da vitória de Vargas nas urnas, ficando a "ala caudilhesca" do PTB com um papel menos importante. ${ }^{162}$

Parece claro que, após definirem-se os critérios de alianças, o PSB buscou maior interlocução com outros setores políticos. O trauma da eleição presidencial de 1950 - com a baixa votação obtida pelo partido e a perturbadora aliança dos antigos aliados com os integralistas - e a gênesis do movimento nacionalista em torno da questão do petróleo aceleraram esse processo, fazendo com que a disputa interna do partido permanecesse indefinida. Cada grupo buscou se antecipar ao novo cenário, tomando iniciativas que evidenciaram as graves divergências internas. Na primeira metade dos anos 1950, havia no PSB

\footnotetext{
${ }^{160}$ GUSTIN, op. cit., p. 75. Sobre a identificação das propostas socialistas com o trabalhismo radical de Jânio Quadros ver também HECKER, op. cit., p. 150.

161 HECKER, op. cit., p. 153. O autor também lembra que determinadas identidades entre o PSB e o PDC remontavam as lutas estudantis em São Paulo contra o Estado Novo e a campanha do brigadeiro Eduardo Gomes em 1945. Ibidem, p. 154.
}

162 ALEM, op. cit., p. 120-121. 
aqueles mais próximos aos centros decisórios do país que perceberam ser possível atenuar as divergências com os trabalhistas, revisando as constantes críticas ao varguismo, que na década anterior se haviam prestado à coesão partidária. Entretanto, a aproximação mais contundente com a "ala ideológica" do PTB se consumaria ao longo da segunda metade da década, quando o nacionalismo reformista se disseminou entre variados atores políticos que não necessariamente gravitavam os poderes centrais. A partir de então, outras divergências apareceriam entre uma nova geração de socialistas embalados pelos novos influxos ideológicos e a Comissão Nacional do PSB, mais cautelosa e não tão disposta a abandonar certas posturas liberais. Em São Paulo, uma parte dos socialistas optou por construir uma ponte alternativa para a política de massas que passasse ao largo de acordos com os diferentes setores do trabalhismo.

Nesse estado, a predominância de líderes como Adhemar de Barros e Hugo Borghi, veementemente criticados pela imprensa socialista, tornava ainda mais inviável qualquer compromisso com tais setores. Nessa perspectiva, a figura de Jânio Quadros abria a oportunidade de assaltar a fortaleza adversária pelo alto, dirigindo apelos por uma renovação ética a um jovem e inexperiente operariado ainda passível de ser cativado por forças políticas não enraizadas no cotidiano urbano. Por fim, restava o núcleo duro da Folha Socialista, crítico aos atalhos políticos e que, por conta disso, buscaram proteger a integridade do programa partidário.

Com o mote do "tostão contra o milhão", Jânio Quadros elegeu-se prefeito derrotando o candidato apoiado por Adhemar de Barros por uma expressiva margem de votos. Segundo Alexandre Hecker, o PSB foi o partido que de fato coordenou a campanha, pois o PDC estava dividido desde a disputa interna pela indicação do nome que concorreria ao pleito. Diferentes expectativas diante do ascenso ao poder ampliaram a divisão também entre os socialistas. Aqueles que estiveram mais comprometidos com a produção teórica que era divulgada na Folha Socialista, pretendiam encarar a participação no movimento liderado por Jânio Quadros como um acordo formal entre forças políticas. Já os que se envolveram com maior intensidade na campanha, inclusive ajustando-se bem no novo governo, inclinaram-se a criar um ideário comum a partir da junção de metas socialistas com as ações janistas. ${ }^{163}$

A favor deste último grupo pesava uma nova realidade experimentada pelos socialistas desde o início da campanha de 1953: o apoio ao candidato do PDC gerou uma vasta migração de elementos janistas para a legenda do PSB. Durante boa parte daquela década, os socialistas

${ }^{163}$ HECKER, op. cit., p. 157. 
conviveriam em seu partido com o séquito de Jânio Quadros, pouco ou nada comprometidos com a identidade partidária. A ala mais ideológica do PSB perdia espaço para discursos políticos geralmente moralizadores, que entendiam que o interesse das classes assalariadas se fundamentava na necessidade de dar maior eficiência à máquina pública e de a tornar liberta de interesses pessoais. A participação dos socialistas no executivo municipal careceria, assim, de uma formulação ideológica mais precisa. ${ }^{164}$

Líder de condutas relativamente independentes das orquestrações interpartidárias, Jânio Quadros desincompatibilizou-se no ano seguinte à vitória na eleição de 1953 para a disputa do governo do estado. Venceu no PSB a opção de reeditar a aliança com o candidato - que agora apresentava-se pelo Partido Trabalhista Nacional. O resultado final do pleito deu vitória a Jânio, vencendo o candidato Adhemar de Barros por uma diferença um pouco abaixo de $1 \%$ do total de votos. ${ }^{165}$ Segundo depoimentos coletados por Miracy Gustin, o comportamento de Jânio Quadros, imediatamente após a vitória eleitoral, abriu uma clivagem ainda mais profunda na configuração interna do PSB:

Após sua eleição, em reunião na residência de Alípio Correia Netto, o
candidato recém-eleito deixa claro aos socialistas sua intenção de governar
sem a interferência política de partidos, quaisquer que fossem eles, tanto que
na escolha de seu secretariado não considerou suas ligações partidárias e, via
de regra, foram escolhidos elementos quase sempre técnicos e que mantinham
certo distanciamento partidário. O partido, desde então, apresenta-se cindido
irremediavelmente em duas facções: 'janistas' e 'não-janistas'. A primeira,
composta por antigos integrantes que passaram a dar apoio irrestrito e ainda
por aqueles que, sendo somente janistas, ingressaram oportunisticamente nas
fileiras do PSB e nunca se transformaram em socialistas. ${ }^{166}$ O inchaço do PSB durante a guinada janista não se restringiu somente ao estado de São Paulo. Novas adesões ocorreram no Rio de Janeiro e também em estados do Nordeste. ${ }^{167}$ Nesta última região, o flerte com a política de massas - ou com o populismo - fortaleceu a tendência

\footnotetext{
164 GUNSTIN, op. cit., p. 76-77. Dentre os membros do PSB, participaram diretamente da administração municipal: Caetano Álvares, Secretário de Obras; Alípio Correia Netto, Secretário de Saúde; Fúlvio Abramo, Diretor de Abastecimento; e Wilson Rahal, Diretor da Companhia Municipal de Transportes Coletivos. Segundo a autora, os resultados alcançados por estes gestores foram bem satisfatórios. Em geral, conseguiu-se maior eficiência, transparência, impessoalidade e regularidade dos serviços públicos prestados naquelas áreas a cargo dos socialistas. Ibidem, p. 75 e 77.

165 Jânio Quadros foi eleito com 660.264 votos (34,2\%), contra 641.960 votos de Adhemar de Barros (33,3\%), 492.518 votos de Prestes Maia (25,5\%) e 79.783 votos para Toledo Piza (4,1\%); também tiveram, entre brancos e nulos, 54.414 votos (2,8\%). Dados do Tribunal Regional Eleitoral de São Paulo, disponíveis em: $<\mathrm{http}: / /$ www.tse.jus.br/eleicoes/estatisticas/repositorio-de-dados-eleitorais>

166 GUSTIN, op. cit., p. 78.

${ }^{167}$ ALEM, op. cit., p. 175.
} 
à formação de frentes políticas que formularam uma acentuada retórica anticoronelista. Segundo Miracy Gustin, líderes nordestinos emergentes ligados ao PSB, tais como Barbosa Lima Sobrinho, Pelópidas Silveira, Francisco Julião e José Joffily, ancoravam-se em discursos modernizantes que ecoavam a lógica anticonservadora do centro político nacional. A autora sublinha que tais discursos denunciavam os entraves da política tradicional personalista, que, segundo alegava-se, impedia a entrada em cena das classes sociais urbanas e o enraizamento de partidos políticos modernos. Se no Sudeste havia o domínio dos elementos trabalhistaministerialistas sobre o operariado, nas áreas periféricas o inimigo a ser combatido eram os coronéis e suas redes políticas clientelistas. ${ }^{168}$ Importante liderança do movimento camponês, a quem militantes do PSB no Sudeste citavam frequentemente com orgulho, Francisco Julião chegou a se referir ao seu próprio partido como um "clube acadêmico, sem nenhuma ação social", defendendo, inclusive, a fusão com o PTB. Segundo seu raciocínio, o PTB, acrescido dos quadros socialistas, poderia expurgar de si o componente do "peleguismo" e tornar-se um partido de massas capaz de "executar uma ação política revolucionária". ${ }^{169}$

Em uma certa perspectiva, a atuação do PSB no Nordeste abriu mais um foco de dispersão do partido no sentido de relativizar o peso de seu programa. Esse teria sido um dos desdobramentos da segunda fase dos socialistas, inaugurada logo que se decidiu pela construção de alianças eleitorais como meio de atingir uma maior visibilidade de seu partido. A opção tomada não chegou a fazer com que o PSB se tornasse um ator preponderante na vida política nacional. Pelo contrário, foram as vicissitudes da política brasileira que passaram a influenciar e interagir mais com o partido. Assim, em meados dos anos 1950, junto à "cruzada moralizadora" que envolvia os simpatizantes de Jânio Quadros, começaria a ganhar espaço no PSB as ideias-chave do nacional-desenvolvimentismo que, a partir do Governo Juscelino Kubitschek, tornou-se expressão ideológica de um amplo setor da sociedade identificado com políticas nacionalistas e reformistas. ${ }^{170}$

Alguns acontecimentos importantes, entretanto, precederam a incorporação mais nítida dos pressupostos nacional-desenvolvimentistas por membros do PSB. Quando do suicídio de Getúlio Vargas, após todo o drama que dividiu a política brasileira em agosto de 1954,

\footnotetext{
${ }^{168}$ GUSTIN, op. cit., p. 57-58.

${ }^{169}$ HECKER, op. cit., p. 90.

${ }^{170}$ Cf. TOLEDO, Caio Navarro de. ISEB: fábrica de ideologias. São Paulo: Ática, 1977; Cf. DELGADO, Lucília Neves de Almeida. Nacionalismo como projeto de nação: a Frente Parlamentar Nacionalista (1956-1964). In: FERREIRA, Jorge; REIS, Daniel Aarão, op. cit.
} 
Domingos Vellasco chegou a declarar que defendia a Constituição e que, daquele momento em diante, convertia-se em um getulista ${ }^{171}$. No ano anterior, Hermes Lima já havia trocado as fileiras socialistas para juntar-se ao PTB e, pouco tempo antes, na V Convenção Nacional do PSB, o partido aprovara teses na direção de uma plataforma política baseada na formação de uma aliança ampla de forças progressistas, pela libertação econômica e pelo bem-estar do povo - a "frente democrática" pela reforma agrária e pela industrialização do país. Havia, assim, um movimento de aproximação de socialistas e trabalhistas, resultante tanto das transformações por que passavam os primeiros, quanto da própria estratégia do PTB de fortalecer o governo Vargas com acenos à direção nacional e aos moderados do PSB. ${ }^{172}$

Com a iminência da eleição presidencial de 1955, as tendências contraditórias no interior do PSB conflitaram, uma vez mais, de forma acentuada. De antemão, condenou-se por unanimidade a candidatura de Juscelino Kubitscheck, percebida naquele momento como identificada com o latifúndio e o com o conservadorismo político. Enquanto a maioria da Comissão Nacional preferia uma aliança com o trabalhismo, em São Paulo a fração identificada com o janismo desejava uma dobradinha Jânio Quadros-Alberto Pasqualini como candidatos a presidente e vice. E novamente surgiu a posição pela candidatura própria, embora em condições mais frágeis que das outras vezes. Jânio, no entanto, recusou-se a participar do pleito, optando por apoiar a candidatura de Juarez Távora, que começava a ser ventilada pela ala da UDN que se opunha a uma possível aliança eleitoral com PSD. O PTB, por sua vez, passava por um momento de desarticulação interna após a morte do seu principal líder, e o nome de Pasqualini como postulante a candidato sucumbiu diante da concorrência de novas lideranças. Contudo, como prova da força exercida pelo janismo na militância do PSB, a maioria do partido inclinouse pela candidatura de Juarez Távora, finalmente oficializada com o apoio da UDN. Por fim, em maio de 1955, reunida na Câmara Municipal do Distrito Federal, a Convenção Nacional do PSB ratificou o apoio ao candidato lançado pela UDN em detrimento das posições que defendiam candidatura própria ou a busca de soluções alternativas ao nome de Juarez Távora. ${ }^{173}$ Após o imenso desgaste gerado pelo debate sobre a sucessão presidencial, o PSB voltava à ala esquerda do liberalismo.

\footnotetext{
${ }^{171}$ ALEM, op. cit., p. 194.

172 Ibidem, p. 176-177. Segundo o autor, as preocupações de Alberto Pasqualini no sentido de dar nova coesão ao projeto trabalhista confluíam com as ideias dos homens fortes do PSB, como João Mangabeira, Domingos Vellasco e Hermes Lima. Ibidem, p. 179.

173 Ibidem, p. 218-224. Foram muitos os protestos que associavam Juarez Távora ao "golpismo" de 1954 e que relembraram a atuação do udenista contrária ao monopólio estatal do petróleo.
} 
A derrota de Juarez Távora e a participação "descaracterizada" dos socialistas na campanha presidencial produziram no PSB importantes mudanças na correlação de forças internas. No Distrito Federal, militantes não afinados com a Comissão Nacional recomendavam a aproximação com partidos cujos programas e ações estivessem, a seu ver, mais de acordo com os princípios socialistas, o que os levou à aproximação definitiva com a "ala autêntica" do PTB, na capital da República. ${ }^{174}$ Conforme Silvio Alem, nesse mesmo período, a Comissão Nacional do PSB viu-se atraída pelas teses desenvolvimentistas fortalecidas com o governo Juscelino Kubistchek, além de ter se identificado com aquele período de relativa liberdade política. ${ }^{175}$ Assim, o movimento de aproximação do PSB ao PTB se deu por vias distintas, expressando diferentes inquietações e expectativas dos grupos socialistas. Começava um movimento de progressiva polarização da política opondo nacionalistas a liberal-conservadores, o que, cada vez mais, exigia posicionamentos mais claros dos partidos. Nesse cenário, os setores emergentes no PSB interessados em articular o ideário socialista com expressões do movimento popular e nacionalista passavam a ganhar espaço, acuando aqueles mais vacilantes que buscavam preservar seu lugar na cúpula partidária. A luta interna prosseguia porquanto as indefinições dos campos políticos nacionais e da própria figura de Jânio Quadros mantinham um tênue equilíbrio na balança.

Em São Paulo, no entanto, seguiu a disputa entre "janistas" e "autênticos"; entretanto, o combate comum às alianças comunistas-trabalhistas na esfera sindical permitiu apoios mútuos em alguns momentos. Contudo, a batalha interna decisiva no PSB paulista ainda estava por ser travada. Nas eleições gerais de 1958, a ala ligada a Jânio Quadros triunfou, elegendo cinco deputados federais (um deles no Rio de Janeiro). Por todo o país o partido experimentou algum crescimento de sua representação no Congresso Nacional e nas câmaras legislativas, consagrando a linha política de coligações com outros partidos. O PRP foi o único partido com o qual o PSB não se coligara, persistindo os socialistas na intransigente denúncia contra a rearticulação do Integralismo no Brasil. ${ }^{176}$

A última eleição presidencial do regime de 1945-1964, causaria, enfim, um efeito depurador no PSB, em favor daqueles grupos de militantes que desejavam reintroduzir no partido uma orientação mais precisa do lugar dos socialistas no arranjo político nacional. Com

\footnotetext{
${ }^{174}$ GUSTIN, op. cit., p. 70-71.

${ }^{175}$ ALEM, op. cit., p. 239.

${ }^{176}$ Ibidem, p. 238.
} 
o PSB dividido e conturbado, colocando-se no horizonte a cisão interna como possível destino do partido, a Comissão Nacional buscou adiar ao máximo o debate sobre qual candidatura apoiar para a sucessão de Juscelino Kubistchek. As opções colocadas dividiram-se entre o apoio a Henrique Teixeira Lott ou a Jânio Quadros, ou, ainda, tornar a "questão aberta" ou mesmo lançar candidatura própria, ventilando-se, neste último caso, o nome de Francisco Julião, então deputado estadual em Pernambuco. ${ }^{177}$ Mas foram as posições pró-Lott e pró-Jânio que polarizaram a Convenção Nacional do PSB, cujos longos e acirrados debates atravessaram os meses de março e abril de 1960. Por fim, venceu a proposta de apoio a Lott, mesmo após os simpatizantes da dobradinha Jânio Quadros-Jango Goulart terem feito as últimas tentativas para que o partido se decidisse pela “questão aberta", evitando-se, assim, o desfecho final. ${ }^{178}$

A candidatura de Lott nascera como um desdobramento da atuação no Congresso da Frente Parlamentar Nacionalista, formada em 1956, ainda no início do governo Kubitschek, como expressão no parlamento da aglutinação de setores da sociedade civil que, em alguma medida, estavam comprometidos com pressupostos do ideário nacional-desenvolvimentista. ${ }^{179}$ Dentre tais setores encontravam-se militantes socialistas, incluindo os parlamentares que se somaram àquela frente. Nessas circunstâncias, a decisão final da Convenção Nacional do PSB de 1960 indica que a maioria dos delegados preferiu opor-se às correntes de opinião mobilizadas em torno da pregação liberal-conservadora. Pois, ainda que a figura paradoxal e extravagante de Jânio Quadros apelasse às classes assalariadas, foi a UDN, antiga aliada dos socialistas, quem animou a campanha do candidato da vassoura, buscando dar a ela um tom moralista e populista de oposição ao reformismo nacionalista, que conciliasse anseios populares com esperanças elitistas. ${ }^{180}$

Na clivagem que marcou profundamente a política brasileira a partir do final dos anos 1950, o PSB condicionaria sua sorte aos rumos do movimento pelas reformas de base, situação que o levaria a sua fase mais radical - a derradeira, interrompida pelo golpe de Estado de 1964.

\footnotetext{
${ }^{177}$ ALEM, op. cit., p. 239-240.

${ }^{178}$ Ibidem, p. 242.

${ }^{179}$ Cf. DELGADO, op. cit.

180 BENEVIDES, op. cit., p. 107.
} 


\subsection{Anos 1960: nacionalismo radical e revolução socialista}

Definido o apoio à candidatura de Henrique Teixeira Lott, o janismo foi definitivamente varrido das fileiras socialistas. Em São Paulo, velhos militantes "autênticos" retomaram o controle do PSB estadual para, em seguida, transferi-lo "em segurança" a uma nova geração de militantes ligados à Juventude Socialista. ${ }^{181}$ Alípio Correia Netto, que desde a formação do PSB havia sido o homem de confiança da direção nacional na presidência da Comissão Estadual de São Paulo, rompera com o partido logo após derrotada a posição de apoio à candidatura de Jânio Quadros - Alípio havia sido um dos maiores entusiastas do janismo no PSB paulista. ${ }^{182}$ Durante o breve governo Jânio Quadros, a bancada socialista no Congresso apoiou a política externa independente do presidente e criticou reiteradamente a política econômica. Na grave crise institucional de 1961, os socialistas engajaram-se na campanha da legalidade e, em seguida, opuseram-se à solução parlamentarista que condicionou a posse de João Goulart. Na Guanabara, a resposta à atuação dos militantes do PSB veio através de duras represálias por parte da polícia a mando do governador Carlos Lacerda. ${ }^{183}$ No início dos anos 1960, reacenderam-se as esperanças nas fileiras do PSB de que o partido viesse a assumir uma maior homogeneidade ideológica, mas, ao mesmo tempo, mantinha-se a tendência no partido a formar frentes e alianças. Naquele momento, a participação nestas frentes e alianças significava para os socialistas sua diluição no bloco nacional-reformista - situação fortalecida com a presença de João Mangabeira como ministro da Justiça (1963) no governo João Goulart, consolidando a aliança com o PTB. ${ }^{184}$

Nas resoluções da IX Convenção Nacional do PSB, realizada em 1961 após a posse de Goulart, as reformas estruturais apareceram como bandeira central a ser defendida pelos socialistas. No entanto, o partido entendia que a mudança recente na forma de governo havia dado uma clara demonstração de que as "manobras das cúpulas partidárias" - ilegítimas, na visão dos socialistas - impunham-se a qualquer manifestação dos interesses populares. Assim, para se assegurar a realização das reformas estruturais contra os interesses dos grupos

\footnotetext{
${ }^{181}$ HECKER, op. cit., p. 184. A presidência da Comissão Estadual de São Paulo foi assumida por Febus Gikovate e repassada a Paul Singer.

182 Ibidem, p. 104.

183 ALEM, op. cit., 276. Segundo Gustin, os socialistas teriam sido os mais barulhentos opositores do parlamentarismo no Congresso. GUSTIN, op. cit., p. 118.

${ }^{184}$ ALEM, op. cit., p. 275. João Mangabeira foi também ministro de Minas e Energia no ano anterior. Porém, ele havia sido nomeado pelo efêmero primeiro-ministro Francisco Brochado da Rocha, do PSD, enquanto a figura do presidente João Goulart jazia à sombra do regime parlamentarista.
} 
econômicos "ligados ao latifúndio e ao imperialismo", o PSB defendia a instauração de uma nova Assembleia Constituinte cuja convocação fosse resultado de um movimento nacional de opinião pública no sentido de ampliar a participação política da população. Por esta perspectiva, os socialistas pleiteavam modificações no Código Eleitoral com vias a assegurar o voto dos analfabetos e militares, "eliminando a influência criminosa do poder econômico" nas decisões políticas. No documento aprovado pela IX Convenção, o PSB declarou sua adesão à Frente Nacional de Libertação, lançada pelo PCB e pela ala esquerda do PTB, a partir da "Declaração de Goiânia". ${ }^{185}$ Os socialistas apostavam que essa frente poderia vir a se tornar um instrumento para impedir novas tentativas de golpe de forças contrárias às reformas de base, mas condicionavam o sucesso de tal instrumento à participação efetiva do proletariado e da classe média, sustentando um programa que expressasse a "autêntica" luta anti-imperialista. ${ }^{186}$

Como é possível identificar nas diretrizes principais do documento de 1961, o PSB optou por dar prioridade às bandeiras e reivindicações que poderiam arrastar mais à esquerda o amplo movimento reformista que se radicalizava no Brasil. Desta forma, não constava mais em primeiro plano o objetivo programático de socializar os meios de produção sob a administração direta dos trabalhadores. Segundo Silvio Alem, se as divergências mais graves entre os socialistas se mostraram dissipadas na IX Convenção, restavam diferentes gradações de radicalidade por debaixo das consignas nacionalistas e anti-imperialistas. ${ }^{187}$

Reunindo informações a partir de entrevistas com ex-militantes do PSB, Miracy Gustin sugere ter havido, na virada da década de 1950 para a de 1960, certa harmonia entre o trabalhismo radical, o movimento reformista e as teses do socialismo democrático. ${ }^{188}$ Além dos fatores advindos da conjuntura histórica brasileira, facilitadores da unidade das esquerdas, elementos da conjuntura externa foram também um importante fator para as transformações do PSB. É reconhecido o impacto que a Revolução Cubana (1959) e a divulgação do "Relatório

\footnotetext{
${ }^{185}$ Após ser formada em um encontro de trabalhadores em Goiânia, a Frente Nacional de Libertação expressou seus objetivos na "Declaração de Goiânia", sendo o principal deles garantir a unidade de nacionalistas e democratas contra as forças golpistas ligadas aos "grupos de espoliação internacionais". Defendia-se, dentre outras medidas, a reforma agrária e restrições aos capitais estrangeiros (controle das remessas de lucros, nacionalização dos depósitos em bancos estrangeiros, etc.). "Declaração de Goiânia". Novos Rumos, n. 142, 27.10-02.11.1961, p. 3. Ao que parece, o PSB identificou de forma superdimensionada o espaço que a Frente Nacional de Libertação teria para atuar, pois são poucos os registros historiográficos que dão conta da existência desta frente política. No entanto, em 1962, surgiu a Frente de Mobilização Popular, reunindo os setores que pressionavam pelas reformas de base. Bastante representativa e atuante, essa frente se extinguiria com o golpe de 1964.

${ }^{186}$ PSB. IX Convenção Nacional (1961). In: CARONE, op. cit., 1981, p. 30-31.

${ }^{187}$ ALEM, op. cit., p. 279.

${ }^{188}$ GUSTIN, op. cit., p. 106.
} 
Kruschev" (1956) tiveram na esquerda brasileira. No caso do PSB, é possível identificar duas consequências principais ocasionadas, em grande parte, pelos dois eventos. A primeira delas refere-se a uma radicalização das formulações do partido, que se tornou, em alguma medida, uma referência à esquerda do movimento nacionalista e reformista da época. Para dentro do PSB afluíram militantes atraídos pelas teses do partido, e também aqueles que opunham à via eleitoral outros métodos de luta revolucionária. ${ }^{189}$ A segunda consequência, ligada à primeira, era que não apenas indivíduos independentes, mas também novas organizações revolucionárias surgidas no período, questionavam a via parlamentar como único caminho ao socialismo. Diversos militantes vinculados a esses pequenos agrupamentos encontraram abrigo na legenda socialista para apresentar-se à população nas eleições de $1962 .{ }^{190}$

Em Minas Gerais, por exemplo, um grupo de jovens inflamados pela Revolução Cubana, militantes da Organização Revolucionária Marxista-Política Operária - que ficou mais conhecida pela denominação Polop - não encontrou dificuldades em utilizar a estrutura do pequeno PSB mineiro para lançar um candidato à Prefeitura da capital e tentar avançar na propaganda revolucionária. As reuniões e o curso de formação política da Polop em Belo Horizonte já aconteciam na sede local do partido. José Maria Rabelo, o candidato lançado pelo grupo, era um militante socialista histórico e também passava por um processo de radicalização política. Carregando no radicalismo, a campanha conseguiu arrebatar $10 \%$ do eleitorado. ${ }^{191}$

Nas eleições gerais de 1962, em meio a um cenário de forte crise econômica e instabilidade política, no qual os círculos conspiratórios da direita se expandiam, a legenda do PSB elegeu um senador, seis deputados federais e dezenove estaduais, todos beneficiados por alianças e coligações eleitorais. ${ }^{192} \mathrm{Na}$ Assembleia Legislativa da Guanabara, recém-criada após a transferência da capital federal, uma bancada socialista de apenas três deputados eleitos pela Aliança Trabalhista-Socialista, atuou em defesa das reformas de base e contra as medidas do governo estadual de Carlos Lacerda. ${ }^{193}$ Simultaneamente, o PSB da Guanabara estabeleceu uma

\footnotetext{
${ }^{189}$ Ibidem, p. 107.

190 ALEM, op. cit., p. 274; Jacob Gorender menciona que, após o golpe de 1964, muitos militantes oriundos do PSB ingressaram na luta armada. GORENDER, Jacob. Combate nas trevas. A esquerda brasileira: das ilusões perdidas à luta armada. 5.ed. São Paulo: Perseu Abramo: Expressão Popular, 2012, p. 138.

191 CHACEL, Cristina. Seu amigo esteve aqui. A história do desaparecido político Carlos Alberto de Freitas, assassinado na Casa da Morte. Rio de Janeiro, Zahar, 2012, p. 27, 33-35.

192 ALEM, op. cit., p. 284.

${ }^{193}$ GUSTIN, op. cit., p. 109. A bancada socialista na Assembleia Legislativa da Guanabara era composta por Jamil Haddad, Pedro Fernandes Filho e Adalgisa Nery.
} 
aliança com Leonel Brizola, então postulante ao cargo de governador do estado nas eleições de 1966. Segundo Luiz Alberto Moniz Bandeira, que foi militante do partido na Guanabara, após o golpe de 1964, diversos socialistas, então na clandestinidade ou no exílio, colocaram-se sob a liderança de Brizola na organização da resistência inicial ao regime militar. ${ }^{194}$

Em São Paulo, as lideranças intelectuais do partido, que há pouco haviam triunfado na disputa contra o janismo, continuavam inexpressivos junto ao eleitorado. ${ }^{195}$ Porém, nas eleições municipais de 1961, os socialistas paulistas haviam concluído pela primeira vez uma aliança com o PTB, apoiando Prestes Maia, o candidato trabalhista à Prefeitura, e lançando José de Freitas Nobre como candidato a vice. ${ }^{196}$ Ambos foram eleitos por boa margem de votos. A explicação para o sucesso da candidatura de Freitas Nobre talvez seja encontrada na influência exercida pela chapa, visto que o partido não logrou impor-se como força independente dentro do movimento mais geral que animava as esquerdas na década de 1960.

No Nordeste, após o assassinato do líder camponês João Pedro Teixeira, em abril de 1962, cresceu a influência do deputado estadual Assis Lemos, do PSB paraibano, junto às Ligas Camponesas. Houve um expressivo fortalecimento da legenda na Paraíba, com sete deputados estaduais eleitos, atraindo nomes de relevo da política estadual - como o já citado José Joffily. Mas neste estado, segundo Miracy Gustin, o ascenso do partido se deveu mais a atuação dos indivíduos do que a uma identidade política que o distinguisse dos outros partidos - da mesma forma como se baseou a trajetória política do pernambucano Francisco Julião. ${ }^{197}$ Em Pernambuco as coisas correram de maneira diferente. Os socialistas participaram ativamente da campanha vitoriosa de Miguel Arraes (Partido Social Trabalhista) para o governo do estado. Empenharam-se também na atuação das Ligas Camponesas e do "Movimento de Cultura Popular" - que unia em frente única socialistas, comunistas e cristãos ocupados em alfabetizar e politizar as camadas populares. O PSB alcançou com isso certo grau de penetração em determinados extratos da população pernambucana, embora isso não tenha se refletido da

\footnotetext{
${ }^{194}$ BANDEIRA, Luiz Alberto Moniz. Trabalhismo e socialismo no Brasil / A Internacional Socialista e a América Latina. São Paulo: Global, 1985, p. 36.

${ }^{195}$ ALEM, op. cit., p. 284-285.

${ }^{196}$ GUSTIN, op. cit., p. 110.

${ }^{197}$ Ibidem, p. 112-113.
} 
mesma forma na representação política do partido no estado, que contou com apenas um deputado na assembleia legislativa. ${ }^{198}$

Para Miracy Gustin, esta última fase do PSB expressou uma diminuição das divergências partidárias internas. Porém, como ressalva a autora, tal processo de homogeneização via radicalismo significou uma derrota do setor que sempre esteve melhor representado na direção nacional do PSB - destacando-se as figuras de João Mangabeira e Domingos Vellasco, “eternas" lideranças do partido. ${ }^{199}$ Esses atores mais moderados optaram pela posição de buscar garantir a próxima eleição presidencial e evitar a radicalização política. ${ }^{200}$ Em síntese, ao firmarem as alianças com os grupos mais radicais do trabalhismo, as "alas ideológicas" do PSB impuseram-se sobre as posições que mantinham aspirações democrático-liberais no interior do movimento nacionalista. Hecker, por sua vez, identifica que nesse período a batalha entre socialistas moderados e radicais tornou-se mais aguçada, a ponto de os paulistas, com o apoio da maioria dos militantes da Guanabara, terem planejado substituir a direção nacional do partido em 1963. Segundo o autor, a possibilidade de que realmente ocorresse uma mudança na cúpula do PSB fez com que a direção nacional protelasse ao máximo as discussões sobre os organismos internos, até que o golpe de 1964 desviou o foco das atenções dos socialistas para fora de seu partido. ${ }^{201}$

Do golpe em 1964 até o AI-2 de 1965, que extinguiu todos os partidos políticos existentes, os socialistas encontraram-se totalmente desarticulados. No momento imediatamente anterior a esse período, o PSB se preparava para dar sequência às "frentes de esquerda" já esboçadas no Brasil, mas não para oferecer resistência a uma eventual contraofensiva golpista por parte da direita militar e civil. A exemplo da esquerda brasileira em geral, os socialistas foram surpreendidos pelo golpe, restando a perplexidade e a desolação. ${ }^{202}$

\footnotetext{
${ }^{198}$ Ibidem, p. 115. A autora aponta como uma das causas da baixa expressão política do PSB pernambucano o fato de que os analfabetos não tinham direito ao voto.

199 Ibidem, p. 108.

200 VIEIRA, Margarida L. de M. "O Partido Socialista Brasileiro e o marxismo (1947-1965)". In: REIS, Daniel Aarão; RIDENTI, Marcelo. (org.). História do marxismo no Brasil. Partidos e organizações dos anos 1920 aos 1960. Campinas: Unicamp, 2002, v. 5, p. 189.

${ }^{201}$ HECKER, op. cit., p. 111.

202 Ibidem, p. 204.
} 


\subsection{O socialismo democrático na evolução do PSB}

A tentativa de afirmação dos preceitos advindos da tradição socialista democrática pelo PSB não se deu sem inúmeros conflitos intrapartidários, apesar da inclinação comum à valorização do modelo do Labour Party. A experiência britânica em particular, e a europeia de modo geral, permitiu o elo entre as aspirações liberadas pelo processo de redemocratização do Brasil e um projeto socializante que se apresentasse realizável a longo prazo. Os motivos para que se assumisse o Labour Party como modelo poderiam variar, mantendo, porém, alguma interdependência: o tom reformista e, de certa maneira, radical de suas propostas; a militância heterogênea; a efetiva sustentação popular e eleitoral; os alicerces com a história do movimento operário; e, finalmente, a busca por uma "terceira via", em oposição ao liberalismo econômico e ao comunismo.

É compreensível, portanto, que a propaganda do PSB lançasse a um futuro totalmente incerto o triunfo do seu ideário. Os índices de participação da população nas eleições eram ainda extremamente baixos. A classe operária, à qual frequentemente se condiciona o sucesso de partidos modernos de esquerda, não representava nem a maior parte da população e muito menos da população votante; e essa mesma classe, que era o alvo principal da pregação socialista, encontrava-se arregimentada por partidos populares eleitoralmente bem mais eficientes. Dessa forma, abrir caminho ao socialismo democrático significava criar condições para uma democracia mais participativa e tornar a classe trabalhadora menos cativável por lideranças carismáticas.

Advinda a inércia e as primeiras manifestações de desilusão - em meio a um cenário crítico para a atuação de sindicatos e partidos de esquerda - soluções atraentes colocaram-se no horizonte. O PSB buscou alianças e coligações com o objetivo de alcançar os primeiros sucessos eleitorais e, enfim, alguma apresentação mais expressiva perante a população. Para os setores mais preocupados com a integridade do programa do partido, o risco da descaracterização doutrinária seria sempre o preço a se pagar pela nova empreitada - que, ao final, não se mostrou tão exitosa como esperado. Por uma perspectiva que isole algum tipo ideal de doutrina socialista democrática, o janismo teria representado, de longe, a maior distorção ideológica vivida pelo PSB. Essa é, sem dúvida, uma leitura a posteriori, que acabou sendo feita pelo próprio partido quando do esgotamento do ímpeto janista.

Os socialistas adaptaram-se mais confortavelmente à efervescência nacionalista e popular a partir de meados de década de 1950. Grosso modo, este fato deveu-se a um 
movimento duplo: por um lado, de adequação às teses nacional-desenvolvimentistas, e por outro, da própria polarização que progressivamente se acentuava na sociedade brasileira - tão maior quanto mais grave se mostrava a crise econômica no início dos nos anos 1960. Por fim, a radicalização política do PSB facilitou a incorporação do partido pela ala esquerda do movimento pelas reformas de base. Antes que o golpe de 1964 desnorteasse o partido por completo, começavam a perder espaço os postulantes de um liberalismo de esquerda, que dominaram a Comissão Nacional do PSB durante toda a sua existência.

É possível indagar em que condições o ideário socialista democrático continuava a disputar espaço, às vésperas do golpe de 1964, com outras formulações políticas derivadas de distintas matrizes teóricas ou desenvolvidas no curso dos acontecimentos das décadas de 195060. Certamente, nenhum conjunto de ideias, por mais rígido que se apresentasse, estaria imune à interlocução com novas demandas surgidas no movimento histórico. No PSB, as divergências estavam postas desde o princípio, o que, em parte, desautoriza análises que predicassem a existência de um projeto "autêntico" do partido em face de forças internas supostamente degenerescentes. No entanto, havia entre os socialistas aqueles que pressionavam para que se atribuísse ao programa partidário o poder de definir uma justa relação entre teoria e prática, de forma que se diminuíssem as margens de influências potencialmente descaracterizadas sobre o partido. Como as pautas políticas da esquerda radicalizaram-se no Brasil no final da década de 1950, muitos socialistas identificaram nelas uma confluência com seu ideário, mas o PSB esteve claramente longe de demonstrar capacidade de coordenar movimentos amplos, como, aliás, nenhum outro partido do período conseguiu fazer.

Evidentemente, na fase radical do PSB, os socialistas experimentaram um clima político muito diferente daquele encontrado em meados de 1940, quando seu projeto de socialismo democrático foi lançado pela primeira vez. No imediato segundo pós-guerra, os socialistas construíram uma retórica baseada no entendimento de que havia profundas mudanças de paradigmas civilizatórios ocorrendo no antigo centro do mundo. Reivindicava-se, assim, que o Brasil fosse parte de uma inflexão mundial que pusesse freios aos expansionismos comunista e capitalista, como se supunha ser o caso do caminho aberto por alguns fatores relacionados ao advento do Estado de bem-estar social. Os próximos capítulos analisarão as condições e os métodos a partir dos quais os socialistas, depois de arregimentar suas forças, buscaram efetivar seu projeto histórico nos anos do imediato pós-guerra. 


\section{Capítulo III - A Esquerda Democrática na Constituinte de 1946}

Reunida pela primeira vez em 2 de fevereiro de 1946, a Assembleia Constituinte tinha a tarefa de redigir a quinta Constituição da história do Brasil - a quarta desde a proclamação da República. Até que o texto final ficasse pronto, o que ocorreu em setembro do mesmo ano, vigorou a Carta de 1937, que centralizava grande poder nas mãos do Executivo. Nas ruas, após a derrota do movimento queremista, várias categorias de trabalhadores ampliavam suas reivindicações, reagindo contra a situação de deterioração das condições de vida que marcou profundamente o Brasil no segundo pós-guerra. Por sua vez, ao passo que seguiam as discussões na Constituinte, o recém-empossado presidente Eurico Gaspar Dutra não hesitou em lançar mão dos dispositivos legais disponíveis para reprimir a atuação organizada dos trabalhadores. ${ }^{203}$

$\mathrm{Na}$ Assembleia Constituinte, o futuro Partido Socialista Brasileiro ainda atuava sob a denominação de Esquerda Democrática. A bancada era pequena e representava uma organização que vivia internamente um intenso debate acerca de suas definições programáticas iniciais. Esse dado é fundamental para se compreender as ambiguidades da atuação da Esquerda Democrática na Assembleia e as formas por vezes difusas pela qual ela buscou encaminhar suas propostas para um Brasil "progressivamente socialista”. O ideário do socialismo democrático estava em gestação no Brasil, e a Constituinte de 1946 tornou-se parte importante desse processo. Neste capítulo analisaremos as contribuições dos membros da Esquerda Democrática à Assembleia Constituinte, dando evidência às formas como eles buscaram se apropriar de alguns dos elementos comuns do ideário socialista dos anos 1940, bem como às peculiaridades dessa apropriação nas condições brasileiras por ocasião do fim do Estado Novo.

\subsection{Breve panorama político à época Constituinte}

Em um período de grande agitação sindical e de deflagração de greves, o novo presidente eleito, Eurico Gaspar Dutra, recorreu a uma série de decretos para governar, dando sequência de certo modo à forma com que Vargas conduziu a ditadura do Estado Novo. Os legisladores que voltavam a ocupar seus assentos após longos nove anos de supressão do

\footnotetext{
203 Para ser mais preciso, o comportamento autoritário do executivo federal havia sido retomado pelo governo interino de José Linhares, presidente do Supremo Tribunal Federal, que antecedeu Dutra após a queda de Vargas. Interrompendo um período de dois anos de abrandamentos na atmosfera política iniciado ainda no Estado Novo, Linhares reprimiu os comunistas ordenando a invasão de suas sedes.
} 
Congresso legislativo não chegaram a servir de contrapeso para a ação unilateral do executivo. Segundo Thomas Skidmore, a UDN, principal partido de oposição, não criou maiores obstáculos ao presidente em seu primeiro ano de exercício, tendo cooperado com o governo no objetivo expresso de reconduzir o país à "normalidade". De fato, deve-se lembrar que a UDN aceitou participar de um dos ministérios de Dutra. Apenas após a Constituição ter sido promulgada é que a disputa partidária aberta teria recobrado seu lugar. ${ }^{204}$

Os comunistas conseguiram eleger em 1945 uma expressiva e disciplinada bancada composta por 15 congressistas que, em alguma medida, desafiavam as forças políticas tradicionais. O PCB obteve, assim, a quarta representação mais numerosa na Assembleia Constituinte, superado apenas por uma pequena margem pelo PTB de Getúlio Vargas. Contando entre outros elementos com o prestígio momentâneo do comunismo internacional e da figura do seu principal líder, Luis Carlos Prestes, o PCB estabeleceu uma ampla base de apoio nas populações assalariadas urbanas, ainda que pese uma série de críticas posteriores que identificam na linha política do partido a adesão à burocracia sindical. ${ }^{205}$ Os comunistas tornaram-se também os mais enérgicos opositores do governo Dutra, denunciando a política do presidente da República tanto no plano econômico quanto em relação às perseguições policiais. A resposta ao crescimento do PCB nos primeiros anos de abertura política seria implacável, sendo o partido posto na ilegalidade em 1947. Antes disso, ainda em 1946, o governo Dutra já havia dado o mesmo destino ao Movimento de Unificação dos Trabalhadores (MUT), que surgiu em abril de 1945 à revelia da legislação trabalhista. Sob a liderança do PCB, o MUT propunha a criação de organismos intersindicais e estimulava a criação de comissões de trabalhadores nos locais de trabalho, cujo papel seria importante em boa parte dos movimentos grevistas deflagrados no período analisado. ${ }^{206}$

\footnotetext{
${ }^{204}$ SKIDMORE, Thomas. Brasil: de Getúlio a Castelo. Rio de Janeiro: Paz e Terra, 1982, p. 98.

${ }^{205}$ A intelectualidade da Esquerda Democrática e, posteriormente, do PSB, já apontava para essa crítica. O grupo formado em torno de Mario Pedrosa, por exemplo, associava a burocratização dos sindicatos controlados pelo PCB à linha estratégica do partido, e esta, por sua vez, aos interesses da diplomacia soviética. Cf. CORREA, Heitor. Comunistas e trabalhistas vs. socialismo e democracia. Vanguarda Socialista, 25.01.1946, p. 3-4. As críticas mais consagradas do comportamento do PCB diante dos sindicatos seriam construídas após o golpe de 1964. Um dos exemplos mais notáveis nesse sentido é a obra de Francisco Weffort, O populismo na política brasileira, editado pela primeira vez em 1978. Uma interessante análise que contextualiza a revisão política e historiográfica em torno da atuação do PCB ao longo do regime de 1945-1964 pode ser encontrada em SANTANA, Marco Aurélio. Entre a ruptura e a continuidade: visões da história do movimento sindical brasileiro. Revista Brasileira de Ciências Sociais, v. 14, n. 41. ANPOCS, 1999, p. 103-120.
}

${ }^{206}$ Cf. MATTOS, Marcelo Badaró. O sindicalismo brasileiro após 1930. Rio de Janeiro: Jorge Zahar, 2003, p. 2728. 
No início da escalada da repressão do governo Dutra - que atingiria um patamar mais elevado no ano de 1947 - setores do sindicalismo sob a esfera de influência dos trabalhistas também foram atingidos. Em setembro de 1946, a partir dos esforços do MUT, foi realizado o I Congresso Sindical dos Trabalhadores do Brasil, no Rio de Janeiro. Na oportunidade, comunistas e militantes ligados ao PTB defenderam maior autonomia sindical. Apesar de os grupos ligados ao Ministério do Trabalho terem apoiado o fechamento do congresso sindical, as discussões prosseguiram até que se aprovasse a criação da Confederação dos Trabalhadores do Brasil (CTB). Um ano mais tarde, logo que o PCB entrou para a ilegalidade, a CTB e as uniões sindicais estaduais também foram fechadas e mais de 400 sindicatos sofreram intervenção. $^{207}$

Se nos meios sindicais o trabalhismo já ensaiava seus primeiros passos no novo regime político brasileiro, o PTB durante a Assembleia Constituinte ainda apresentava contornos indefinidos. Para Ângela de Castro Gomes, “o partido encontrava-se conturbado e cindido", já demonstrando vocação para as urnas, como expressão da vontade de Getúlio Vargas, mas em termos organizacionais ainda permanecia sendo uma "ficção". ${ }^{208}$ Somente com o retorno de Vargas às atividades políticas durante a campanha eleitoral de 1947, após seu "exílio" voluntário em São Borja, é que o PTB começaria a ganhar força e identidade ao ocupar parte do terreno deixado vago pela cassação dos comunistas. ${ }^{209}$

Um ano após a promulgação da Carta de 1946, Luiz Carlos Prestes, ao ressaltar a contribuição dos comunistas na Constituinte, declarou que se chegou a uma Constituição democrática, ainda que em sua opinião não se tenha atingido diretivas mais progressistas. Alvo de inúmeras críticas e provocações vindas dos próprios parlamentares, o PCB ocupou-se, durante grande parte dos trabalhos, em denunciar a perseguição política sofrida pelo partido, além de defender um projeto específico de reforma agrária. ${ }^{210}$

Em relação à reforma agrária defendida pelos comunistas, é importante destacar que ela assumia um lugar central para os pressupostos teóricos do PCB, coadunando-se com a linha

\footnotetext{
207 Cf. Ibidem, p. 29-30. Sobre a criação da CTB e o papel desempenhado pelos comunistas no período, ver COLISTETE, Renato. Labour relations and industrial performance in Brazil. Greater São Paulo, 1945-1960. Houndmill: Palgrave, 2001.

${ }^{208}$ GOMES, Ângela de Castro. A invenção do trabalhismo. Rio de Janeiro: FGV, 2005, p. 294.

${ }^{209}$ SKIDMORE, op. cit., p. 101.

210 PRESTES, Anita Leocádia. Os comunistas e a Constituinte de 1946 - por ocasião do $60^{\circ}$ aniversário da Constituição de 1946. Estudos Ibero-Americanos, PUCRS, v. XXXII, n.2, p. 171-186, dez. 2006, p. 183.
} 
estratégica do partido que visava suprimir os vestígios de feudalismo que supunham ainda existirem no Brasil e que, em sua opinião, impediam o proletariado de ingressar em uma nova etapa de desenvolvimento das forças produtivas do país. Os socialistas, por sua vez, apresentaram na Constituinte uma visão distinta em relação ao tema, prevendo soluções técnicas para, ao mesmo tempo, incrementar a produtividade no campo e garantir os meios para uma progressiva socialização das atividades agrícolas.

Em relação às discussões sobre o direito de propriedade, o PCB preferiu não defender as expropriações, conforme os levantamentos feitos pelo historiador da Constituinte de 1946, João Almino:

Os comunistas acreditavam que, naquela fase de consolidação da ordem burguesa do Brasil, a propriedade privada desempenharia um papel fundamental. O liberalismo e a visão de mercado do Partido se explicavam, além disso, pela crença de estar o mundo vivendo um momento em que, em razão das ameaças reacionárias e fascistas, era necessária uma aliança entre a classe operária e a pequena e grande burguesias. Esta aliança serviria, entre outras finalidades, (...) para eliminar os restos de feudalismo ainda existentes. $^{211}$

Como veremos, a Esquerda Democrática adotou outra postura, optando, inclusive, por dar destaque à discussão sobre o direito de propriedade e assumir uma atitude menos liberal em relação a ela.

Em 18 de setembro de 1946, promulgou-se a nova Constituição da República. Em obra introdutória à Carta de 1946, publicada pelo Senado, o constitucionalista Barbosa Lima Sobrinho aponta que foram poucas as divergências em relação à Constituição de 1934. Resgatou-se preceitos democráticos desta obra e, mais importante, afastou-se o autoritarismo fascista da Carta de 1937. ${ }^{212}$

A Esquerda Democrática, recém-agrupada, pouco tempo teve para desenvolver sua elaboração teórica. Heterogênea na sua composição, a organização lançou-se na Assembleia Constituinte tendo como representantes elementos mais ou menos comprometidos com um projeto político-partidário que se pretendia homogêneo. Em contraste com os anos seguintes, os trabalhos conduzidos em 1946 pelos candidatos eleitos pela Esquerda Democrática podem ser vistos como um primeiro processo de ajustes programáticos, uma vez que o agrupamento realizou sua I Convenção quando já havia decorrido alguns meses da instalação Constituinte.

\footnotetext{
${ }^{211}$ ALMINO, op. cit., p. 39.

212 SOBRINHO, Barbosa Lima. A Constituição de 1946. In: BALEEIRO, Aliomar e SOBRINHO, Barbosa Lima. (Orgs.). Constituições brasileiras: 1946. Brasília: Senado Federal, 2001, p. 25.
} 
A seguir, tentaremos reconstituir a situação do partido durante esse período, privilegiando suas vozes mais destacadas e com a finalidade de compreender melhor suas contradições internas. Estas contradições são entendidas aqui como contradições próprias da construção do socialismo democrático no Brasil.

\subsection{Uma fotografia da Esquerda Democrática à época da Constituinte}

A historiografia diverge quanto à composição exata da bancada da Esquerda Democrática na Assembleia Constituinte de 1946. Sérgio Soares Braga considera que o grupo socialista tenha sido formado apenas pelos deputados Hermes Lima e Domingos Vellasco. ${ }^{213}$ Já para Margarida Vieira e Miracy Gustin, o deputado Jurandir Pires também fez parte das fileiras da Esquerda Democrática, não tendo ainda abandonado o agrupamento àquela altura. ${ }^{214}$ No entanto, no artigo do Correio da Manhã de abril de 1946, no qual a Esquerda Democrática é alvo da crítica mordaz da coluna assinada por Carlos Lacerda, o jornalista definiu a bancada socialista como formada por Domingos Vellasco, Hermes Lima, Gilberto Freyre e Nestor Duarte. ${ }^{215}$ Este último não consta nas listas dos historiadores mencionados acima, mas seu nome aparece novamente em artigo do Jornal do Brasil como fazendo parte da Esquerda Democrática. ${ }^{216}$ Mesmo com quatro ou cinco nomes, porém, fica claro que nas eleições de 2 de dezembro de 1945, a Esquerda Democrática elegeu pela sigla da UDN um número bastante reduzido de representantes, em um universo de 338 parlamentares - incluindo os suplentes que em algum momento tomaram parte nos trabalhos da Constituinte. ${ }^{217}$

Pela dificuldade de precisar com exatidão a pequena bancada socialista, esse capítulo levará em consideração as intervenções em plenário dos seguintes deputados: Domingos Vellasco (Goiás), Hermes Lima (Distrito Federal), Jurandir Pires (Distrito Federal), Nestor Duarte (Bahia) e Gilberto Freyre (Pernambuco). A escolha pelos cinco nomes abarca, portanto, não apenas os congressistas que em algum momento atuaram na Constituinte como

\footnotetext{
${ }^{213}$ BRAGA, Sérgio Soares. Quem foi quem na Assembleia Constituinte de 1946. Brasília: Câmara dos Deputados, 1998, p. 41.

${ }^{214}$ VIEIRA e GUSTIN, op. cit., p. 417.

${ }^{215}$ LACERDA, Carlos. O caso das cinco pernas. Correio da Manhã, 07.04.1946, p. 2

${ }^{216}$ A semana no Palácio Tiradentes. Jornal do Brasil, 28.07.1946, p. 4.

${ }^{217}$ Dados detalhados acerca da composição da Assembleia Constituinte de 1946 podem ser encontrados na obra de Sérgio Soares Braga citada acima.
} 
representantes socialistas, mas também aqueles que seguramente estiveram presentes na formação da Esquerda Democrática.

O critério que nos leva a incluir os cinco parlamentares assume que, nesse período, as intersecções entre a Esquerda Democrática e a UDN no âmbito parlamentar não permitem definir com clareza os limites da primeira em relação à segunda. Entretanto, como vimos no capítulo anterior, o agrupamento socialista era intransigente quanto a sua independência programática no interior da frente que sustentou a candidatura de Eduardo Gomes à presidência da República. Contudo, passadas as eleições, é possível perceber um movimento substancial de políticos eleitos por um determinado partido em direção a outras legendas durante ou ao final de seus mandatos. Esse é um sinal de que o novo sistema político do pós-guerra ainda gestava suas próprias clivagens, uma vez que os caminhos da política nacional se construíam não apenas sobre as velhas tensões do Estado Novo, mas também refletindo as novas constelações de interesses.

A Esquerda Democrática não estava imune a esse processo, principalmente ao se levar em conta que, nos primeiros anos de atuação da organização, seus nomes mais proeminentes no cenário político eram aqueles ligados a tradições liberais. É apenas com o passar do tempo que o agrupamento se enquadraria com maior precisão no cenário político, assumindo, inclusive, um maior centralismo organizacional interno. Ressalta-se ainda que a UDN desse período não representava ainda - ou somente - o ideário liberal-conservador que, mais tarde, demarcaria o seu lugar na história do Brasil contemporâneo. Em 1946, a luta contra o ditador e a campanha derrotada do Brigadeiro Eduardo Gomes eram uma lembrança viva o suficiente para manter diversos simpatizantes do manifesto inaugural da Esquerda Democrática dentro da esfera de influência dos udenistas. Assim, enquanto Hermes Lima e Domingos Vellasco tinham claro o desejo de formalizar a Esquerda Democrática como partido, devidamente registrado na Justiça Eleitoral, Nestor Duarte preferiu aderir às fileiras da UDN, enquanto Gilberto Freyre, ao exercer seu primeiro e único mandato parlamentar, não mais demonstraria o mesmo interesse pela vida político-partidária.

Feitas essas considerações, vale destacar que uma ausência notável na bancada da Esquerda Democrática na Constituinte foi a da principal figura pública da organização, João Mangabeira, cuja votação não foi suficiente para conduzi-lo ao Palácio Tiradentes. Mangabeira se juntaria aos seus colegas somente após o fim da Assembleia Constituinte, ao ser eleito deputado federal nas eleições complementares de 1947, que preencheram as vagas para o Congresso ordinário. Contudo, o jurista baiano e herdeiro intelectual de Rui Barbosa não foi 
relegado a segundo plano nesse curto - porém decisivo - período de tempo, atuando com destaque em prol da consolidação da Esquerda Democrática no cenário político nacional. Exemplo disso é sua presença na comissão eleita pelo partido para formular um projeto próprio de Constituição. ${ }^{218}$

Reconstituiremos, a seguir, a trajetória dos representantes da Esquerda Democrática até sua chegada à Assembleia Constituinte, além de sugerir um esboço da situação de outros setores dentro do partido capazes de intervir no debate estratégico interno.

O goiano Domingos Vellasco integrou o movimento tenentista nos anos 1920 e, após ter participado da revolta de 5 de julho de 1924, em São Paulo, foi reformado no posto de primeiro-tenente. Cinco anos mais tarde, apoiou a formação da Aliança Liberal, tomando parte na Revolução de 1930. Com o interesse de radicalizar os rumos do movimento revolucionário e defender o ideário original do tenentismo, ingressou no Clube 3 de Outubro. ${ }^{219}$ Quando estourou a Revolução Constitucionalista de 1932, Vellasco foi nomeado comandante-geral das forças goianas em combate às tropas paulistas revoltosas. No ano seguinte, foi um dos fundadores do Partido Social Republicano de Goiás, ocupando a ala esquerda do agrupamento e sendo eleito para representar seu estado na Assembleia Nacional Constituinte de $1934 .{ }^{220} \mathrm{Na}$ oportunidade, Vellasco apresentou uma emenda propondo maior centralização e intervenção do Estado na economia, inclusive com a socialização de empresas "quando assim exigisse o interesse público". A emenda previa, ainda, que fossem limitados os lucros de empresas que desempenhassem serviços públicos, "pertencendo o excesso, em $2 / 3$, à União, aos estados ou aos municípios". A justificativa era a da necessidade de prover recursos para uma direção mais planificada da economia nacional, a qual estaria desprovida de solidez porquanto submetida à "política dos governadores". Eleito deputado federal no mesmo ano, passou a integrar a Aliança Nacional Libertadora (ANL), tornando-se, em diversas ocasiões, porta-voz da entidade contra

\footnotetext{
${ }^{218}$ A Esquerda Democrática na elaboração da nova Constituição. Correio da Manhã, 16.03.1946, p. 3. Além da presença de Mangabeira, completavam a comissão: Castro Rebelo, Homero Pires, Hermes Lima, Domingos Vellasco, Otavio Tarquinio de Souza, Osorio Borba e Hariberto de Miranda Jordão.

${ }^{219}$ Sobre o tenentismo, a Aliança Liberal e os clubes 3 de outubro, ver: CARONE, Edgard. O tenentismo. Rio de Janeiro: Difel, 1975; FORJAZ, Maria Cecília Spina. Tenentismo e Aliança Liberal (1927-1930). São Paulo: Pólis, 1978; WIRTH, John D. O tenentismo na Revolução de 30. In: FIGUEIREDO, Eurico de L. (Org.). Os militares e a Revolução de 30. Rio de Janeiro: Paz e Terra, 1979; SODRÉ, Nelson Werneck. O tenentismo. Porto Alegre: Mercado Aberto, 1985; PRESTES, Anita Leocádia. Tenentismo pós-30: continuidade ou ruptura? São Paulo: Paz e Terra, 1999.

${ }^{220}$ Sobre o Partido Social Republicano de Goiás, consultar o verbete em: BRESSANE, Regina. Partido Social Republicano de Goiás. In: ABREU, Alzira Alves de et al (Coord.). Dicionário Histórico-Biográfico Brasileiro - Pós-1930. Rio de Janeiro: CPDOC, 2010.
} 
os atos de repressão da polícia política varguista. ${ }^{221}$ Assim, Vellasco opôs-se à Lei de Segurança Nacional aprovada em 1935 e, após o recrudescimento da repressão que se seguiu ao putsh comunista naquele mesmo ano, acabou encarcerado com outros deputados dentre os quais João Mangabeira, que seria seu fiel companheiro de Esquerda Democrática e PSB. ${ }^{222}$ O deputado foi julgado e absolvido em 1937, voltando a ocupar, por pouco tempo, sua cadeira no Congresso até o golpe do Estado Novo. Não encontramos informações do rumo tomado por Vellasco após a instauração da ditadura. Seu nome, porém, retornou às páginas dos noticiários quando da constituição da UDN durante o processo de redemocratização do país. Antes de eleito deputado federal em 1945, Vellasco foi um dos principais protagonistas envolvidos na formação da Esquerda Democrática, da qual tornou-se secretário-geral. ${ }^{223}$

Nascido na Bahia, Hermes Lima seguiu carreira de jurista, tendo sido convidado por Anísio Teixeira, em 1935, para dirigir a Faculdade de Direito da Universidade do Distrito Federal, criada naquele mesmo ano sob o governo do interventor Pedro Ernesto. Paralelamente, Hermes Lima desempenhou função de jornalista em alguns dos principais jornais do Rio de Janeiro e de São Paulo. Também em 1935 ligou-se à ANL, em nome da qual publicou diversos artigos com o objetivo de defender a democracia do fascismo e do clericalismo conservador. Após o fracasso do putsch comunista de novembro, Hermes Lima foi imediatamente detido, permanecendo em reclusão por pouco mais de um ano. Posto em liberdade, logo deparou-se com a instauração do Estado Novo, o que o obrigou a afastar-se da redação de $O$ Correio da Manhã. Assim como Domingos Vellasco, Hermes Lima retornou à vida pública durante o processo de redemocratização do país. Antes de se juntar à Esquerda Democrática, Hermes Lima foi uma das principais figuras envolvidas no I Congresso Brasileiro de Escritores realizado em São Paulo no início de 1945, e que teve importante contribuição para o deslanchar da reação pública em cadeia contra o Estado Novo. Anistiado nos estertores da ditadura, Hermes Lima assumiu o cargo de professor na Universidade do Brasil. ${ }^{224}$

221 Sobre a ANL, ver: CARONE, Edgard. A República Nova (1930-1937). 3.ed. São Paulo: Difel, 1982; HERNANDEZ, Leila Maria Gonçalves Leite. Aliança Nacional Libertadora: ideologia e ação. Porto Alegre: Mercado Aberto, 1985.

222 Sobre o putsch comunista de 1935, ver: SODRÉ, Nelson Werneck. A Intentona Comunista de 1935. Porto Alegre, Mercado Aberto, 1986; PRESTES, Anita Leocádia. Luiz Carlos Prestes e a Aliança Nacional Libertadora. Os caminhos da luta antifascista no Brasil (1934/35). São Paulo: Brasiliense, 2008.

${ }^{223}$ Cf. KELLER, Vilma. Domingos Vellasco. In: ABREU, Alzira Alves de et al (Coord.). Dicionário HistóricoBiográfico Brasileiro - Pós-1930. Rio de Janeiro: CPDOC, 2010.

${ }^{224}$ Cf. COUTINHO, Amélia. Hermes Lima. In: ABREU, Alzira Alves de et al (Coord.). Dicionário HistóricoBiográfico Brasileiro - Pós-1930. Rio de Janeiro: CPDOC, 2010. 
Formado pela Escola Politécnica do Rio de Janeiro, Jurandir Pires era quem reunia as características de tecnocrata do grupo de deputados da Esquerda Democrática. A despeito disso, Pires mostrou-se tão envolvido em questões de natureza ideológica quanto seus correligionários, comportamento, aliás, bastante característico dos membros da agremiação. Ainda no exercício da profissão de engenheiro, Jurandir Pires atuou no planejamento de importantes obras em diversas regiões do país. Seu pai cumpriu extensa carreira política como deputado federal pelo Piauí durante a Primeira República, e como senador na legislatura de 1947-1951. Ambos estiveram exilados em Lisboa logo após a Revolução de 1930. Já tendo retornado ao Brasil, e ao longo de todo o Estado Novo, Jurandir Pires chefiou o gabinete do ministro da Viação, João de Mendonça Lima. ${ }^{225}$ Carece-se de informações a respeito do que o levou à oposição à ditadura de Vargas e a integrar a Comissão Nacional provisória da Esquerda Democrática. Fato é que, assim que foi promulgada a Constituição de 1946, transferiu-se para o PSD.

Assim como João Mangabeira e Hermes Lima, seus conterrâneos, Nestor Duarte também se formou na Faculdade de Direito da Bahia. Após a Revolução de 1930, juntou-se à Liga de Ação Social e Política da Bahia, organizada em 1932, e cuja principal exigência era a substituição de Juracy Magalhães por um civil baiano no comando do estado. Por opor-se ao Estado Novo, Nestor Duarte ficou preso por um curto período em 1938, tendo posteriormente participado do I Congresso Brasileiro de Escritores, além de ter sido um dos organizadores de primeira hora da Esquerda Democrática durante o processo de redemocratização do país. No entanto, após a Constituinte, Nestor Duarte tornou-se secretário da Agricultura, Indústria e Comércio da Bahia no governo de Octávio Mangabeira (1947-50), durante o qual já estava vinculado à UDN. ${ }^{226}$

Sendo dispensável discorrer sobre a importância já então consagrada de Gilberto Freyre para o pensamento social brasileiro, cabe mencionar apenas alguns fatos que antecederam o seu ingresso na Esquerda Democrática. Entre 1930 e 1932, Freyre esteve exilado na Europa junto com o governador pernambucano deposto, Estácio Coimbra, de quem havia sido secretário particular até a fase final da República Velha. Retornando ao Brasil, Freyre ingressou como professor na Faculdade de Direito do Recife e, a pedido de Anísio Teixeira, transferiu-se mais tarde para a Universidade do Distrito Federal. Freyre também participou de diversos

\footnotetext{
${ }^{225}$ Cf. verbete Jurandir Pires. In: ABREU, Alzira Alves de et al (Coord.). Dicionário Histórico-Biográfico Brasileiro - Pós-1930. Rio de Janeiro: CPDOC, 2010.

${ }^{226}$ BRAGA, Sérgio Soares. Op. cit., p. 204-205.
} 
movimentos de oposição à ditadura do Estado Novo e foi um dos signatários do manifesto inaugural da Esquerda Democrática. Entretanto, como já mencionado anteriormente, ele discordou da orientação de transformar o agrupamento em partido político formal, o que ocorreu em meados de 1946. Desse momento em diante, Gilberto Freyre se afastaria dos círculos organizados pelos socialistas. ${ }^{227}$

Além da ausência de João Mangabeira, a qual já nos referimos, a combativa Esquerda Democrática de São Paulo também não conseguiu eleger representantes. Na verdade, a comissão paulista parecia estar ainda longe das possibilidades de obter sucesso eleitoral significativo, vivendo nessa fase os desafios de consolidar sua militância de base. Apesar do papel dos paulistas nas lutas contra o Estado Novo e na produção de um extenso e qualificado arcabouço teórico que sustentava sua ação, em meados dos anos 1940 sua inclinação expressa nas páginas do periódico Folha Socialista tendia mais ao refinamento de sua organização partidária, ou seja, à tarefa de dar forma e conteúdo ao Partido Socialista que desejavam criar por sobre uma Esquerda Democrática ainda amorfa em muitos aspectos. Um Partido Socialista que, mantendo a forma de partido "aberto", como eram os da Internacional Socialista, tivesse penetração entre os trabalhadores a fim de disputar sua influência com seus concorrentes diretos: o PCB, o PTB e, destacadamente em São Paulo, o Partido Social Progressista, de Adhemar de Barros, e o Partido Trabalhista Nacional, de Hugo Borghi. ${ }^{228}$

O jornal da comissão paulista da Esquerda Democrática, a Folha Socialista, só começaria a ser veiculado em 1947, alguns meses após o término da Constituinte. Esse fato torna mais difícil a investigação das posições do grupo em relação aos debates na Assembleia Constituinte. Situação diferente vivia o grupo articulado em torno do periódico Vanguarda Socialista, do Rio de Janeiro, cuja edição ficava a cargo de Mário Pedrosa, um dos precursores do trotskismo no Brasil. A essa altura, em 1946, já rompidos com o programa trotskista e influenciados por socialistas como Marceau Pivert, Giuseppe Saragat e Julián Gorkin, Mário Pedrosa e seus companheiros também aspiravam à construção de um Partido Socialista brasileiro. ${ }^{229}$ Esse grupo considerava que a Esquerda Democrática tinha um caráter pequeno-

\footnotetext{
${ }^{227}$ BRAGA, Sérgio Soares. Op. cit., p. 507.

${ }^{228}$ Sobre o modelo de partido defendido pelos paulistas, ver D'HORTA, Arnaldo Pedroso. Como deve crescer um partido democrático. Folha Socialista, n. 1, 27.11.1947, p. 2.

${ }^{229}$ FERREIRA, Oliveiros S. Vanguarda Socialista. Folha Socialista, n. 8, 10.06.1948, p. 8. Sobre a relação de Mário Pedrosa com o socialismo democrático, ver: LOUREIRO, Isabel. Mario Pedrosa e o socialismo democrático. In: MARQUES NETO, José C. (Org.). Mario Pedrosa e o Brasil. São Paulo: Fundação Perseu Abramo, 2001.
} 
burguês, situando-se entre a burguesia liberal e o proletariado, o que consequentemente se refletiria em um programa democrático-radical que não levaria adiante aspirações vistas como genuinamente socialistas. O fator positivo, segundo o Vanguarda, seria a presença nas fileiras da Esquerda Democrática de grupos proletários realmente de esquerda, concorrendo para levar a agremiação ao caminho da independência de classe e da formação de um partido decididamente socialista. Com isso, Mario Pedrosa e seu grupo pretendiam ingressar na Esquerda Democrática para transformá-la por dentro, apoiando os elementos socialistas revolucionários que julgavam lá se encontrar. ${ }^{230}$

A adesão formal de Mário Pedrosa e seus colegas ao PSB ocorreu em 1948, ocasião em que o Vanguarda Socialista tornou-se o órgão oficial da Comissão Nacional do partido. Dois anos antes, no primeiro semestre de 1946, entretanto, o Vanguarda Socialista teve recusado o pedido de ingresso na Esquerda Democrática, justamente quando esta se preparava para sua I Convenção Nacional. Coincidentemente ou não, o debate acerca da transformação da Esquerda Democrática em Partido Socialista era o mais aguardado às vésperas da convenção. Na época, Domingos Vellasco chegou a afirmar à imprensa que a admissão na organização era permitida a todos que estivessem de acordo com os desígnios programáticos da Esquerda Democrática, “mas não àqueles que desejassem infiltrar-se para ‘trotskizarem' ou 'stalinizarem' ou, em suma, a 'marxistizarem' a organização". ${ }^{231}$

Pesava contra os animadores do Vanguarda Socialista o fato de, diferentemente dos paulistas, não terem eles se articulado com o processo de arregimentação da Esquerda Democrática a partir de meados de 1945. Não obstante, naquela ocasião, o grupo também havia declarado apoio à candidatura do Brigadeiro Eduardo Gomes. Em 31 de agosto de 1945, a edição inaugural do Vanguarda Socialista, falando em nome dos "socialistas independentes e revolucionários ou comunistas dissidentes que constituem o grupo que edita o semanário", acusava o "prestismo" de ter dividido o movimento democrático a partir do momento em que optara pela adesão ao queremismo. Por esse motivo, a derrubada da ditadura e a instauração de um governo provisório com traços populares tornara-se uma oportunidade perdida. Como em uma nova ofensiva, "a candidatura de Eduardo Gomes passou a ser o elemento aglutinador na luta contra o Estado Novo e pela democratização do Brasil”. Na campanha para tentar eleger o Brigadeiro, a defesa das bandeiras democráticas não significava para o Vanguarda Socialista

\footnotetext{
${ }^{230}$ Nós e as eleições. Vanguarda Socialista, 23.11.1945, p. 1 e 5.

231 A Esquerda Democrática. Correio da Manhã, 16.05.1946, p. 1.
} 
um fim em si mesma, mas objetivava criar um terreno mais favorável para "a organização autônoma e independente das classes trabalhadoras, tanto no domínio econômico como no domínio político, no social, como no cultural”, condição tida como indispensável para que pudesse haver um movimento socialista no Brasil. ${ }^{232}$ A visão que o grupo mantinha sobre a democracia liberal pode ser sintetizada nesta passagem de um artigo publicado em seu periódico, em que discute as tarefas de um futuro Partido Socialista brasileiro:

[Tal partido] não esconderá seus objetivos: a instauração do socialismo no país. Para tanto, seus métodos de ação serão aqueles que as próprias condições históricas determinem: atividade geral dentro dos quadros da democracia, mas, quando isso for impossível, não terá dúvidas em recorrer aos métodos de ação tradicionais do movimento socialista internacional. ${ }^{233}$

Segundo avaliação do Vanguarda Socialista anterior à I Convenção Nacional da Esquerda Democrática, em abril de 1946, o grupo de socialistas paulistas que poderia servir de ponta-de-lança para o amadurecimento político do partido, encontrava-se podado pelo comportamento antidemocrático da Comissão Nacional. Esta, para conter as tendências mais esquerdizantes no interior da organização, contaria então com o suporte de uma direção estadual “fantoche” em São Paulo, à época encabeçada por Alípio Corrêa Neto. ${ }^{234}$ Veterano da Força Expedicionária Brasileira e figura proeminente da Faculdade de Medicina da Universidade de São Paulo, da qual seria Reitor anos mais tarde, Alípio Corrêa Neto figurava mais notadamente como um ilustre militar e uma autoridade da medicina do que como um político da Esquerda Democrática. Porém, diferentemente de seus pares moderados da direção nacional do partido, Alípio convivia com o encargo de intermediar o relacionamento entre as diferentes correntes de pensamento dentro do PSB paulista. ${ }^{235}$ A Comissão Nacional, como vimos anteriormente, apenas seria ameaçada em sua posição de mando a partir do final da década de 1950.

Apesar das controvérsias, em carta aberta à Comissão Nacional da Esquerda Democrática, um mês após esta realizar sua I Convenção, Mário Pedrosa declarou que o Vanguarda Socialista reconhecia no programa aprovado pela organização um nítido reflexo no Brasil do "socialismo democrático" que, na Europa, estabelecia suas diferenças com o

\footnotetext{
${ }^{232}$ Posição política. Vanguarda Socialista, 31.08.1945, p. 1 e 4.

${ }^{233}$ MELO, Plinio. A tarefa histórica da Esquerda Democrática. Vanguarda Socialista, 12.04.1946, p. 4.

${ }^{234}$ LEAL, J. Carvalho. O trambolho da Esquerda Democrática. Vanguarda Socialista, 01.02.1946, p. 6.

${ }^{235}$ HECKER, op. cit., p. 45 e 104.
} 
"comunismo autoritário". ${ }^{236}$ De qualquer modo, Pedrosa e seus companheiros não se furtariam em seguir problematizando em seu órgão de imprensa os rumos da Esquerda Democrática e a atuação desta na Constituinte.

Nessa fase inicial da Esquerda Democrática, não se pode dizer que os núcleos que se formaram fora do eixo Rio-São Paulo podiam influenciar significativamente o centro decisório do partido. Como vimos no capítulo anterior, essa situação se modificaria na segunda metade da década de 1950, quando o PSB alcançou alguma abrangência nacional. A partir daí socialistas como os de Minas Gerais, Pernambuco e Paraíba introduziriam novas demandas à vida partidária, refletindo os temas suscitados pelo desenvolvimento da economia brasileira como, por exemplo, o das reformas de base. Em 1946, no entanto, os jornais noticiavam apenas a instalação de novas comissões municipais e estaduais em determinadas regiões do país, atestando a incipiência da militância em pontos mais distantes da agitada vida política da Comissão Nacional da Esquerda Democrática. Era comum, por exemplo, que os chefes do partido se deslocassem para o interior do Brasil para discursar na inauguração de novas comissões, muitas delas provisórias. Assim, enquanto Domingos Vellasco percorria seu estado natal com a missão de desfraldar a bandeira do socialismo democrático, João Mangabeira, desimpedido do trabalho parlamentar, encarava as longas distâncias entre o Sudeste e o Nordeste com o mesmo propósito, assim como os membros da Comissão Estadual de São Paulo alcançavam êxito ao disseminar novos núcleos partidários em boa parte do território paulista.

Após um levantamento dos aspectos partidários internos, cabe, por último, uma avaliação da posição modesta do que a Esquerda Democrática representava no universo político brasileiro em 1946. Havia um consenso dentro da organização: expressasse ou não o que se tinha por interesses históricos das classes assalariadas, a decisão proveniente das urnas deveria ser não apenas soberana, mas também a pedra de toque da evolução da democracia no Brasil. A exemplo da social-democracia na Europa ocidental, que sofrendo diversos percalços cresceu ao longo de décadas e institucionalizou-se, o trabalho dos socialistas brasileiros deveria se orientar no sentido do crescimento da representatividade partidária entre a população. Ocorre que, pela notoriedade de que já desfrutavam, os constituintes da Esquerda Democrática elegeram-se por motivos outros que não necessariamente o sucesso da difusão de suas propostas socializantes - embora não seja justo desprezar a importância da identificação desses personagens com ideias mais à esquerda, sobretudo para o eleitorado de classe média da capital

236 PEDROSA, Mario. Carta aberta à Comissão Nacional da Esquerda Democrática. Correio da Manhã, 15.05.1946, p. 2. 
federal. ${ }^{237}$ Em suma, é notório que a bancada eleita pela Esquerda Democrática representava a tradição mais liberal do partido. Em outras palavras, eram liberais esquerdizantes.

Carlos Lacerda na sua já citada "Tribuna da Imprensa", então uma coluna do jornal Correio da Manhã, ressaltou o academicismo do grupo e seu vínculo quase inexistente com as massas. Desferindo duras críticas à organização, Lacerda diz que Esquerda Democrática comportava-se como um "clube de esquecidos", incompatível com um movimento de fato popular e incapaz de dar vazão às suas ideias. Sobre o apregoado socialismo democrático, Lacerda sustenta que tal lema poderia englobar qualquer coisa. Na prática, porém, a Esquerda Democrática estaria dando poucos passos para tornar-se a força socialista que ainda permanecia ausente na política brasileira. Esse espaço, segundo o jornalista, havia sido raptado pelo "fascismo trabalhista", muito mais hábil na tarefa de angariar apoio popular do que a frágil Esquerda Democrática. Além disso, estaria lhes faltando a coragem para enfrentar Luiz Carlos Prestes - que os chamava de "esquerda entre aspas" - caindo-se no erro de acreditar ser ainda possível convencer os comunistas a saírem da órbita de Vargas e do PTB. ${ }^{238}$

Além da suposta identificação da Esquerda Democrática com os comunistas, denunciada pelos liberais-conservadores mais exaltados, houve também aqueles, como o jornalista e socialista declarado Edmundo Moniz, que simpatizavam com a ideia de que surgisse no Brasil um partido socialista, mas que se inquietavam com a crise de identidade da Esquerda Democrática:

Se a ED não é propriamente um partido socialista, como já asseverou o deputado Domingos Vellasco, por que se separou da UDN? Para enfraquecer a ação dos liberais? Para retardar a obra de redemocratização do país? A ED só tem razão de existir como partido socialista. A não ser desta forma não passa de um movimento para dividir as correntes democráticas, servindo igualmente a Prestes e às forças reacionárias. ${ }^{239}$

Interpelado certa vez acerca da pouca representatividade da Esquerda Democrática, João Mangabeira expôs a crença de que haveria para a organização um espaço no futuro, e que, com o fim de alcançá-lo, os socialistas não abririam mão de seus princípios. Para Mangabeira, a

\footnotetext{
${ }^{237}$ O caso de Domingos Vellasco ilustra bem essa situação: quando da formalização da Esquerda Democrática, os eleitores de Vellasco em Goiânia teriam ficado descontentes em saber que seu candidato não mais falaria em nome da UDN na Assembleia, e sim como representante de posições "esquerdistas". Embora na prática o deputado sempre tivesse atuado de forma independente dos udenistas, os diretórios municipais da UDN naquela cidade exigiam nada menos que sua renúncia ao cargo. Exigem a renúncia do deputado Vellasco. Correio da Manhã, 02.08.1946, p. 3.

${ }^{238}$ LACERDA, Carlos. Op. cit.

${ }^{239}$ MONIZ, Edmundo. O Stalinismo e a Esquerda Democrática. Correio da Manhã, 28.07.1946, p. 33-34.
} 
Esquerda Democrática diferia dos demais partidos por não se imiscuir na política de favores e de compra de votos, e por seus militantes terem compreensão da importância de seu programa. Quanto ao comportamento diante de governos, os socialistas sustentariam o pragmatismo diante de cada decisão, atuando como "fiscal justo, severo e vigilante". Mangabeira caracterizava o partido como "pobre e novo, sem ajuda de banqueiros ou governos, que não só luta para vencer, pois luta-se também para perder". Por fim, asseverava: "às vezes ganha-se mais perdendo". ${ }^{240}$

\subsection{Expectativas socialistas no início dos trabalhos da Constituinte}

Diferentemente de todas as demais Constituintes da história brasileira, na de 1946 não foi apresentado um anteprojeto de Carta Magna que balizasse desde o início as discussões da Assembleia. Todo o trabalho de elaboração da Constituição ficou a cargo do próprio poder legislativo, assim como a metodologia adotada para dar cabo do processo. Decidiu-se pela criação de uma Comissão de Constituição, que teria a tarefa de elaborar um anteprojeto para acelerar os trabalhos. A comissão, que também ficou conhecida como a "Grande Comissão", foi formada por 37 membros, tendo Nereu Ramos (PSD) e Prado Kelly (UDN) como presidente e vice-presidente, respectivamente. ${ }^{241}$

A Comissão de Constituição subdividiu-se em dez subcomissões encarregadas cada uma de um dos tópicos estipulados como fundamentais à redação final. Os tópicos em questão não foram uma inovação de 1946. Eles seguiam, na verdade, a estrutura já existente na Carta de 1934 que, como a de 1891, consistia nas referências conscientemente adotadas pela maioria dos membros da Assembleia - o que pode ser verificado em vários discursos. Segundo José Duarte, autor de um exaustivo trabalho de análise da Constituinte de 1946, foi de fato resolvido que se usaria como referência as Constituição de 1891 e 1934, "incorporando o que fosse indispensável à adoção de novos dispositivos e os aperfeiçoamentos ditados pela experiência". ${ }^{242}$ Para Aliomar Baleeiro, que também participou da Comissão de Constituição, a aproximação dos

\footnotetext{
${ }^{240}$ Fala o Sr. João Mangabeira da Esquerda Democrática. Correio da Manhã, 10.12.1946, p. 1.

241 BALEEIRO, Aliomar. A Constituinte e a Constituição Federal de 1946. In: BALEEIRO, Aliomar e SOBRINHO, Barbosa Lima. Constituições brasileiras: 1946. Brasília: Senado Federal, 2001, p. 13-14.

242 DUARTE, José. A Constituição brasileira de 1946. Exegese dos textos à luz dos trabalhos da Assembleia Constituinte. Vol. 1. Rio de Janeiro: Imprensa Nacional, 1947, p. 132 e 136.
} 
textos de 1934 e 1946 teria sido a coincidência de fatores políticos: nos dois momentos reagiuse aos "excessos do presidencialismo" ou a "tendências ditatoriais" como as de $1937 .{ }^{243}$

Poder-se-ia especular em adição que a memória de 1934 permitiria ao menos estabelecer um consenso inicial entre as principais forças da situação e da oposição, favorecendo com isso alguma harmonia na abertura dos trabalhos de 1946. Afinal, a grande maioria dos parlamentares havia tomado parte nos acontecimentos pré-1937, antes, portanto, que a ditadura produzisse divisões definitivas em um ambiente político que, até então, desenrolava-se em um contexto de relativa liberdade democrática - em que pese a grande mobilização política e as medidas repressivas registradas ainda antes do golpe do Estado Novo.

Representando a Esquerda Democrática, Hermes Lima conseguiu se incorporar à concorrida Comissão de Constituição, atuando na subcomissão "Da Ordem Econômica e Social" ${ }^{244}$ A opção de integrar essa subcomissão foi coerente com a preocupação prioritária dos socialistas em discutir o direito de propriedade com vistas a credenciar o Estado de instrumentos de socialização progressiva dos meios de produção. Contudo, a nomeação de Hermes Lima não se deu sem protestos. Estes vieram sobretudo da bancada do PSD, "que se mostrou alarmada com a suposta preponderância de elementos "esquerdistas"” naquele meio. ${ }^{245}$ Hermes Lima, por sua vez, também não tinha em boa conta seus pares, pelo menos quanto à capacidade destes de desempenhar um trabalho verdadeiramente progressista. Suas expectativas eram bem menos otimistas do que o clima geral que permeava a Assembleia Constituinte. Discursando na Comissão de Constituição, o deputado qualificou a Assembleia como conservadora, que nesse ponto pouco diferia das suas predecessoras. Apesar dos seus esforços, Hermes Lima sustentou que não vislumbrava uma alteração dos fundamentos da ordem econômica e social do Brasil, mas insistiu que pelo menos os direitos do trabalho tivessem a mesma atenção e o mesmo nivelamento dos direitos da propriedade privada. ${ }^{246}$

\footnotetext{
243 BALEEIRO, Aliomar op. cit., p. 57. Na opinião do autor, mesmo que tivesse havido predisposição dos parlamentares em reagir a excessos de centralismo do Executivo, a Carta de 1946 não conseguiu superar uma "exacerbação do presidencialismo". Baleeiro sugere, ainda, que isso tenha sido motivado pela "precária organização dos partidos” em um contexto de recente redemocratização. Ibidem, p. 20.

${ }^{244}$ Completavam a subcomissão: Agamêmnon Magalhães, Adroaldo de Mesquita, Baeta Neves e Café Filho. Cf. DUARTE, op. cit., p. 133.

${ }^{245}$ Reação e revolução. Correio da Manhã, 24.03.1946, p.1. O próprio colunista defende a presença de Hermes Lima e lembra que a Comissão de Constituição estava repleta de elementos que referendaram a Constituição de 1937 e seguiam impregnados de predisposições fascistas, ignorando "que houve no mundo certas transformações sociais a que não poderemos ficar insensíveis e alheios".
}

${ }^{246}$ DUARTE, op. cit., p. 123. 
O próprio Hermes Lima estava convencido de que, nas condições em que se apresentava a composição da Assembleia Constituinte, era mais cabível retornar aos ideais que nortearam as outras constituintes republicanas. Em seu discurso de abertura da Comissão de Constituição, ao salientar que a tarefa da Assembleia seria mais de restauração do regime destruído pelo golpe de 1937, o deputado declarou:

Não vamos inovar, vamos buscar nas próprias fontes da nacionalidade, nas nossas tradições, o fio que se quebrou, por causas que não vem a pelo mencionar. (...) não devemos estar empiricamente a tentar soluções naquilo que, pelo menos, durante 40 anos, assegurou ao Brasil um regime de paz e progresso. $^{247}$

Ao mesmo tempo, se Hermes Lima comprometia-se com a restauração das diretrizes democráticas pré-1937, também não se furtou a exigir avanços constitucionais, entendidos como avanços da própria democracia:

Precisamos elaborar uma Constituição democrática que sirva de instrumento à eliminação das condições miseráveis em que vive o povo brasileiro. Não é possível, portanto, deixar de pensar, como imposição da hora presente, na necessidade de uma reforma agrária, uma reforma que garanta maior produção, maior participação do homem rural nos benefícios, nos resultados de seu trabalho, até porque é, hoje, voz corrente entre os técnicos, autorizados estudiosos da nossa economia, que a produção agrária brasileira está praticamente estacionária há cerca de quinze anos. (...). Não basta uma democracia formal de mero conteúdo político; a democracia é uma forma admirável de convívio político, mas é mister que ela sirva de instrumento de reivindicações mais profundas do povo, que está democraticamente organizado. Em face da elaboração constitucional de que estamos encarregados, a grande questão é conhecer, não só as condições de vida, como a situação social do povo brasileiro, porque a finalidade da Constituição democrática, que estamos dispostos a votar, não pode ser outra senão a de promover o progresso social dos nossos concidadãos. ${ }^{248}$

Como Hermes Lima, Nestor Duarte partilhou do raciocínio que via na Constituinte de 1946 uma tarefa menos criadora do que restauradora. A exemplo do colega, Nestor Duarte identificava no Estado Novo - e na Carta de 1937 - um infeliz interlúdio, que teria interrompido o destino histórico da nação brasileira. Em discurso proferido na tribuna da Assembleia, o deputado baiano concebeu uma evolução jurídica iniciada com a Constituição de 1891, que instituiu a República e o federalismo, e complementada pela Constituição de 1934, introduzindo, por sua vez, "princípios do socialismo, sob a forma de democracia social e segundo o modelo em voga da Constituição de Weimar”. Finalmente, concluía Nestor Duarte,

\footnotetext{
${ }^{247}$ Ibidem, p. 109.

${ }^{248}$ Ibidem, p. 119.
} 
os constituintes de 1946 tinham diante de si a possibilidade de se reencontrar com os caminhos da "tradição brasileira", aprendendo com os próprios descaminhos que "a marcha da liberdade" tomou. $^{249}$

Em sentido bastante distinto dos parlamentares em evidência nas passagens acima, o grupo do Vanguarda Socialista nutria expectativas auspiciosas em relação à Constituinte, a começar por entendê-la como uma nova fase política que superava a condição de "mendicância" a qual a classe trabalhadora esteve submetida sob o regime de Vargas. Se dos constituintes pouco ou nada se podia esperar, a sua própria indiferença às demandas populares tornava-se um convite constante à luta. A Constituinte se converteria, assim, em um instrumento para que os grupos sociais menos privilegiados, ao reivindicarem direitos sob as mais variadas formas, ganhassem maioridade política e se habituassem a uma atividade independente e autônoma. E para o Vanguarda, no específico quadro histórico-político brasileiro, independência e autonomia significavam principalmente a ruptura com o varguismo:

A Constituinte não lhes dá nem pão, nem carne, nem leite, nem água. A Constituinte lhes dará, porém, o direito de berrar, de sair à rua, de cruzar os braços e não trabalhar, de protestar contra patrões e governo, exploradores de qualquer natureza. Essas pobres massas mistificadas por tantos anos de demagogia totalitária terão que compreender que Getúlio não lhes deu nada disso, Getúlio, ao contrário, só lhes deu a mais a carestia dos gêneros alimentícios. $^{250}$

Como se nota, as expectativas do Vanguarda estavam menos no trabalho dos constituintes do que na pressão que os trabalhadores poderiam exercer sobre eles. Mais do que isso, o grupo esperava que durante a Constituinte pudessem surgir diretrizes que desatrelassem os sindicatos da "demagogia totalitária” imposta durante os anos em que Getúlio Vargas ocupou o poder. Aliás, a perspectiva de concretização desse ideal sempre mereceu atenção especial dos socialistas na década de 1940. Remover as heranças do Estado Novo significava ao mesmo tempo reorganizar a classe trabalhadora de forma autônoma e independente tanto do sindicalismo ministerialista, quanto do trabalhismo e do comunismo. Durante a Constituinte, no entanto, os membros da Esquerda Democrática teriam de atuar sem a base de apoio que um dia aspiravam representar. Essa ausência os socialistas buscariam suprir no Congresso com propostas remodeladoras da relação entre Estado e sociedade. Conforme veremos no item

\footnotetext{
249 Anais da Constituinte, Vol. XII, p. 250-251.

${ }^{250}$ A corja fascista e a Constituinte. Vanguarda Socialista, 22.02.1946, p. 1 e 4.
} 
seguinte, as liberdades sindicais almejadas não eram vistas pelos socialistas apenas como uma demanda brasileira, mas antes como imposição de uma nova realidade internacional.

\subsection{O acerto de contas com o fascismo e com o Estado Novo}

Apesar de pouco numerosos, os deputados da Esquerda Democrática mostraram-se bastante atuantes durante os quase oito meses de trabalhos da Assembleia Constituinte. No princípio, os socialistas preocuparam-se principalmente em realizar no plenário um balanço da luta contra o fascismo e ditar a ela uma nova perspectiva. Conforme a leitura que faziam da conjuntura inaugurada no pós-guerra, a derrota das forças do Eixo e o fim do Estado Novo não significavam que o inimigo havia desaparecido do cenário internacional ou da política brasileira. Sobre esta última, pesava ainda a vigência da "humilhante" Carta de 1937. Revogála o mais depressa possível tornou-se a questão prioritária para os socialistas - objetivo que não seria alcançado até que a nova Carta fosse promulgada. ${ }^{251}$ Nota-se, portanto, que para a Esquerda Democrática o fascismo europeu e o Estado Novo mantinham estreita afinidade.

A marca do recente combate à ditadura figurava na segunda metade dos anos 1940 como um notável traço identitário de toda a militância da Esquerda Democrática. Rememorando o cárcere estadonovista, Domingos Vellasco discursou, no início de 1946, proclamando a Esquerda Democrática a vanguarda da luta contra a rearticulação do fascismo no Brasil. ${ }^{252}$ Semanas mais tarde, o deputado voltou à tribuna da Assembleia Constituinte para ler um documento elaborado pela “Comissão Paulista Pró-Revogação da Carta de 37”, que considerava a "carta fascista" uma filha dos "conchavos" entre o governo ditatorial "com o setor mais reacionário de forças econômicas internacionais, com sede em Roma e Berlim". 253

Havia motivos para que a Esquerda Democrática se sentisse confortável em reivindicar a dianteira da luta contra o que considerava o "fascismo estadonovista". Em primeiro lugar, entre os grupos de esquerda, o PCB comprometera-se, durante o processo de abertura política, a apoiar o movimento que reivindicava a convocação da Constituinte com a continuidade de

\footnotetext{
${ }^{251}$ O requerimento de revogação da Constituição de 1937 foi apresentado pela UDN e derrotado em votação por 143 votos contra 93. Hermes Lima foi um dos que subiu à tribuna para justificar seu voto a favor da revogação. Cf. A sessão de ontem da Assembleia Constituinte. Jornal do Brasil, 28.02.1946, p. 6.

${ }^{252}$ Anais da Constituinte, Vol. I, p. 281-282.

253 Anais da Constituinte, Vol. II, p. 343-344. Os signatários do documento e principais articuladores da referida comissão foram, em sua maioria, os intelectuais da seção paulista da Esquerda Democrática. Mesmo permanecendo de fora da teia parlamentar de 1946, e de certa forma distantes da Comissão Nacional do partido, os paulistas buscaram por esses meios as primeiras formas de incidir no debate político nacional.
} 
Vargas na Presidência. Os comunistas calculavam que com a entrada crescente de trabalhadores na política brasileira, o queremismo daria ao partido mais espaço para desenvolver a sua linha de "união nacional". Em segundo lugar, os adversários do ditador no campo liberal, arregimentados na UDN, misturavam-se dentro de um partido cujas figuras de proa não pareciam estar dispostas a levar muito longe sua defesa de liberdades democráticas. Pois, renunciar a certos controles sobre a classe trabalhadora, forjados no Estado Novo, poderia significar, por exemplo, um recrudescimento indesejado da agitação social que se mantinha nas ruas, e não a recondução do país à "normalidade". ${ }^{254}$

A respeito da agitação social no início do governo Dutra, foi novamente Domingos Vellasco quem tomou a frente para fazer a leitura de outro documento, assinado pela Comissão Nacional da Esquerda Democrática, no qual o partido apresentava sua análise da conjuntura e responsabilizava Vargas pela situação vivida naquele momento. Segundo o texto, a ditadura deixara como herança a crise econômica que favorecia a disseminação de greves devido ao aumento do custo de vida do trabalhador em proveito de certos setores industriais. Em troca, uma débil legislação trabalhista teria sido elaborada para mascarar os efeitos impopulares da política econômica. Em apelo ao Executivo para que a normalidade fosse restaurada, o documento recomendava que a "política de força" do novo presidente fosse substituída por uma "política de inteligência", que reduzisse as emissões de moeda, cortasse despesas supérfluas e fomentasse a produção em um clima de colaboração entre patrões e trabalhadores. Aos primeiros, caberia garantir a justa retribuição ao trabalho e contentar-se com lucros razoáveis; aos segundos, persistir em uma atitude ordeira uma vez que "a paralisação do trabalho acarreta diminuição da produção e concorre para o aumento do custo de vida". 255

O documento, entretanto, destoou das posições normalmente assumidas pela Esquerda Democrática de São Paulo, ilustrando o descompasso entre os paulistas e a Comissão Nacional baseada no Distrito Federal. Mesmo contendo a intransigente crítica à ditadura do Estado Novo, apelos diretos à colaboração de classe como solução para os problemas nacionais não eram uma marca dos artigos publicados na Folha Socialista, aproximando-se tais apelos muito mais à "união nacional" defendida pelo PCB. A contar pela postura inicial de seus parlamentares, é provável que as expectativas da Comissão Nacional da Esquerda Democrática em relação ao novo regime fossem grandes o suficiente para se confiar que o fortalecimento da democracia

\footnotetext{
${ }^{254}$ Sobre a agitação social em 1945 e anos seguintes, ver FRENCH, John D. Drowning in laws. Labour law and Brazilian political culture. Chapel Hill: The University of North Carolina Press, 2004.

255 Anais da Constituinte, Vol. III, p. 51-53.
} 
exigia sacrifícios impostos a todos. Também é provável que houvesse aqui a influência de uma visão um tanto particular do espírito social-democrata que considerasse anacrônico fomentar maiores antagonismos de classe.

A situação se alteraria com o acirramento da repressão do governo Dutra às atividades

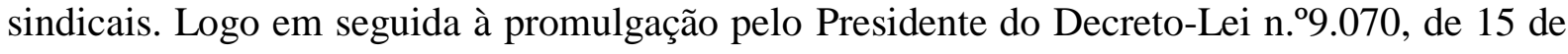
março de 1946, que na prática tornava impossível a realização de greves dentro da legalidade, Hermes Lima fez violento discurso na Assembleia Constituinte classificando a medida como fascista. ${ }^{256}$ Se até então os socialistas confiavam em uma nova ordem mundial em que forças democráticas triunfantes poderiam firmar um compromisso em torno de reformas sociais, pelo bem da própria democracia, o ambiente da Guerra Fria pode ter produzido, pouco a pouco, desesperanças quanto à possibilidade de uma diplomacia de paz duradoura e em uma guinada democratizante da política global. Normalmente se atribui ao governo Dutra a efetivação de um processo de alinhamento do Brasil ao campo da agressiva política externa norte-americana sob a Doutrina Truman. No entanto, nos primeiros anos do pós-guerra havia alguma margem para expectativas positivas em relação à implementação do "terceiro campo" socialista democrático. Assim, a emergência do Estado de Bem-Estar Social, com intenção expressa por parte da socialdemocracia europeia de consolidar um caminho próprio de atendimento das demandas das classes trabalhadoras, teria sido um forte argumento em favor dos socialistas.

Além da crítica ao autoritarismo do pré e do pós-1945, o liberalismo econômico e o comunismo de tipo soviético também foram alvos constantes de discursos dos parlamentares da Esquerda Democrática durante a Constituinte. Como vimos, se o partido carecia de uma sólida unidade ideológica, seus militantes conseguiam ao menos se unir na contrariedade a esses três elementos. É a partir do meio para frente dos trabalhos da Assembleia que as propostas socialistas começaram a apresentar-se de forma mais clara, diferenciando-se das demais orientações ideológicas concorrentes. O momento coincidiu com a realização da I Convenção Nacional da Esquerda Democrática, entre os dias 7 e 14 de abril de 1946, no Rio de Janeiro. É compreensível, portanto, que o embate com o alegado "fascismo varguista", que se iniciou na luta contra o Estado Novo, começasse a dividir cada vez mais espaço com novas bandeiras políticas e novas definições programáticas. Nesse sentido, o esforço dos paulistas liderados por Febus Gikovate foi fundamental para a aprovação pelo partido de teses mais à esquerda.

${ }^{256}$ Anais da Constituinte, Vol. IV, p. 62-63. 
Em entrevista às vésperas da Convenção, João Mangabeira, além de fazer as referências já mencionadas ao modelo do Partido Trabalhista britânico, argumentou que a Esquerda Democrática caminhava para uma uniformidade programática que se balizava na defesa da socialização progressiva dos meios de produção através de processos democráticos. Para tanto, seria necessário eliminar, não mediante ruptura revolucionária, mas por vias graduais, "os representantes feudais que entravam o progresso". ${ }^{257}$ Embora a bandeira da progressiva socialização dos meios de produção constasse desde o início nos documentos da Esquerda Democrática e aparecesse nas propostas levadas à Constituinte, a leitura que concebia a existência de entraves de restos feudais na economia brasileira não era oficializada pelo partido. ${ }^{258}$ Como no caso da "colaboração de classes", que mais parece ter sido tomada de empréstimo do ideário comunista do imediato pós-guerra, aqui também se verifica uma zona indefinida, ou mesmo obscura, em que distintas leituras da realidade brasileira se sobrepõem sem acabamentos mais criteriosos. O fato de tal declaração ter sido feita pelo presidente da Esquerda Democrática é revelador das ambiguidades que acompanharam a constituição do socialismo democrático no Brasil no pós-guerra.

Na leitura dos socialistas, se o fascismo no Brasil permanecia camuflado como ameaça em potencial ou como fragmentos ainda não varridos da política, o foco internacional do fascismo seria, em tese, mais facilmente debelável. Sob o lema da solidariedade internacional, Hermes Lima e Domingos Vellasco discursaram com frequência defendendo o fim das relações diplomáticas com a Espanha franquista e com Portugal salazarista, ressaltando a contradição da manutenção dessas relações uma vez que o Brasil havia se posto ao lado das forças democráticas nos campos de batalha. Segundo Hermes Lima, a península ibérica representava um foco de infecção fascista que abruptamente poderia converter-se em elemento contaminador de todo o organismo internacional - além, é claro, de representar uma realidade incompatível com os aprendizados que a recente catástrofe oferecia. Para o deputado, a guerra demonstrara

\footnotetext{
${ }^{257}$ Reúne-se amanhã em Convenção Nacional a E.D. Folha da Manhã, 06.04.1946, p. 12.

258 Com relação ao campo, o "Manifesto da Esquerda Democrática" - então o principal documento norteador do agrupamento - identifica que "a estrutura agrária tradicional do país, tem desde a fase colonial, mantido a população rural num baixo nível de vida e impedido o desenvolvimento técnico das atividades agrícolas". Em seguida, o documento diz que, para reverter esse quadro, faltam ainda estudos especializados no país para que se faça uma necessária reorganização da economia agrária brasileira. Porém, concebe-se que essa reorganização deve, dentre outras coisas, estimular a pequena propriedade, distribuir terras não aproveitadas e instruir tecnicamente os agricultores. "Manifesto da Esquerda Democrática".
} 
que a causa da paz era indissociável da causa da democracia, sendo mister apoiar a luta de libertação do povo ibérico, inclusive militarmente. ${ }^{259}$

Por fim, cabe mencionar o quanto também os paulistas da ED - e principalmente eles valorizavam a identificação de sua organização com o combate ao fascismo. Quando a comissão paulista lançou Germinal Feijó candidato a deputado por São Paulo, sua propaganda veiculada na imprensa centrava-se sobretudo nesse tema. ${ }^{260} \mathrm{Ei}-\mathrm{la}$ :

Germinal Feijó sempre esteve onde está o povo: pela Abissínia contra Mussolini, pela Espanha Republicana contra Franco, pelas Nações Unidas contra Hitler, pelo Brasil contra a ditadura de Getúlio Vergas e dos exploradores do povo. ${ }^{261}$

O teor de certa forma exagerado da propaganda, é uma demonstração da determinação dos socialistas em persistir no referido combate, uma vez que, em uma campanha eleitoral, geralmente as referências ao passado pressupõem os compromissos futuros.

A Assembleia Constituinte de 1946 ofereceu à bancada da Esquerda Democrática um espaço privilegiado para levar adiante o acerto de contas com o passado e apresentar propostas no sentido de preparar a democracia liberal para futuras reformas sociais. Veremos adiante como essas propostas foram encaminhadas.

\subsection{Um projeto "progressivamente" socialista para o Brasil}

Para recontar o projeto de Brasil sustentado pelos socialistas na Assembleia Constituinte de 1946, seria muito oportuno analisar o documento produzido pela comissão da Esquerda Democrática designada a elaborar seu próprio modelo de Constituição. Entretanto, não há indícios de que esse documento tenha sobrevivido ao tempo, não sendo sequer mencionado pela literatura especializada. Isso não impede, todavia, através da investigação dos Anais da

\footnotetext{
${ }^{259}$ Anais da Constituinte, Vol. II, p. 32-33; O Sr. Hermes Lima pleiteará o rompimento das relações do Brasil com o Governo de Franco. Folha da Manhã, 06.01.1946, p. 12.

${ }^{260}$ Como muitos militantes da Esquerda Democrática de São Paulo, Germinal Feijó (1917-1999) formou-se na Faculdade de Direito da Universidade de São Paulo. Durante esse período, tornou-se um dos fundadores da UNE, e participou em publicações e protestos contra o Estado Novo. Foi oficial de gabinete do prefeito Jânio Quadros e elegeu-se deputado estadual em duas oportunidades (1954 e 1958). Em 1962, já no PTB, candidatou-se a deputado federal, assumindo uma suplência. Após o golpe de 1964, Feijó ingressou no MDB, assumindo uma cadeira vaga de deputado federal devido às diversas cassações de congressistas perpetradas pelo regime militar. Nos anos 1980, trocou o PMDB pelo PSDB. Cf. ABREU, Alzira Alves de et al (Coord.). Dicionário HistóricoBiográfico Brasileiro - Pós-1930. Rio de Janeiro: CPDOC, 2010.
}

${ }^{261}$ Folha da Manhã, 30.11.1945, p. 15. 
Constituinte e de outras fontes, um exame acerca dos pontos básicos que nortearam a atuação da bancada socialista. ${ }^{262}$ De antemão, pode-se destacar que o fundamento organizador dessa atuação estava presente desde o manifesto da Esquerda Democrática de 1945, reproduzindo-se incessantemente no discurso de sua militância, a saber: a progressiva socialização dos meios de produção sem qualquer processo de ruptura institucional. No entanto, a forma como essa "bandeira máxima" traduziu-se nas posições dos parlamentares socialistas na Assembleia, revela um comportamento partidário não tão sincronizado como se poderia esperar de um pequeno agrupamento em busca de coesão ideológica.

\subsubsection{Estado, propriedade e capital estrangeiro}

Dentre os membros da Esquerda Democrática na Constituinte, Domingos Vellasco parecia ser o mais preocupado em dar máxima evidência à diferenciação do seu partido com os comunistas. A forma pela qual o deputado buscou realizar essa tarefa nada lembrava os embates entre socialistas e comunistas no cenário internacional. Também não refletia as críticas mais bem elaboradas ao bolchevismo, ao stalinismo ou ao prestismo produzidas por intelectuais da Esquerda Democrática de São Paulo, dentre os quais se destacavam Febus Gikovate, Fúlvio Abramo, Aziz Simão e Germinal Feijó. Sempre se autodeclarando cristão antes de qualquer outra coisa, ao tecer suas críticas aos "abusos" da propriedade privada, Vellasco lançou mão de preceitos mais associados aos partidos democratas-cristãos do que com os da tradição socialista. Por extensão, a exemplo de muitos outros congressistas, o deputado esbravejava críticas comuns contra os comunistas, mas ressaltando que as ideias destes eram incompatíveis com a sociedade sem classes que ele projetava.

Em plenário, Vellasco atribuiu todos os problemas da democracia aos males do liberalismo econômico, reafirmando, "enquanto católico", sua "independência em face do comunismo ateu e do capitalismo burguês". Declarando-se defensor "das massas espoliadas e oprimidas contra os injustos privilégios da riqueza", disse comungar com muitas das reivindicações econômicas dos comunistas por serem elas, antes, reivindicações cristãs. O combate ao "comunismo ateu", segundo o deputado, só se tornaria eficaz à medida que fossem atendidos os interesses do povo "contra a ambição desmedida de seus exploradores". E, ao tratar

\footnotetext{
${ }^{262}$ Não foi possível obter acesso aos registros das discussões travadas na Comissão de Constituição (incluindo suas subcomissões). Algumas informações acerca da atuação da Esquerda Democrática nesse espaço, através da figura de Hermes Lima, foram antecipadas na seção 3.3 deste capítulo com base na obra de José Duarte, já referida, e serão examinadas a partir das fontes de jornais da época.
} 
do "detestável" imperialismo, Vellasco criticou o discurso de Prestes, que o antecedera na tribuna, por não incluir a Rússia "dentre as potências que têm interesses de domínio político ou econômico sobre outros povos". 263

No mesmo ano de 1946, simultaneamente à vigência da Constituinte, Domingos Vellasco publicou um pequeno livro com o título Rumos Políticos, em que pretendia demarcar seu lugar como, ao mesmo tempo, cristão e socialista (embora a palavra "socialismo" o incomodasse a ponto de preferir que a Esquerda Democrática jamais mudasse seu nome para Partido Socialista). Sob a influência das encíclicas de Pio XI e Pio XII, o texto apresenta o que seria para o autor a mais depurada doutrina social cristã. Segundo Vellasco, ao fazer a crítica do comunismo e do fascismo, o cristão não deveria cometer o erro de defender os interesses da burguesia reacionária, uma vez que seria estranho ao cristianismo confundir-se com o conceito do individualismo econômico, "que considera a propriedade um direito ilimitado sobre as coisas". Para Vellasco

O justo uso dos bens materiais é uma característica fundamental do conceito cristão da propriedade. Ele se opõe vigorosamente ao conceito individualista liberal. Não é o direito de usar e abusar que o dono tem sobre as coisas (...). É perfeitamente cristão, a meu ver, admitir que determinadas fontes de riqueza ou meios de produção não devem pertencer ao domínio privado, porque eles dão a seus donos um tal poderio que constituem ameaça à paz social. ${ }^{264}$

Por outro lado, a concepção de "socialização cristã" de Domingos Vellasco não preconizava o Estado como instrumento que pudesse, por si só, garantir a distribuição mais equilibrada das riquezas. Citando Pio XII, o deputado argumentava que o Estado não poderia assumir um fim em si mesmo, adquirindo um império ilimitado e tornando-se mandatário da nação, do povo, da família ou de uma classe social. ${ }^{265}$ Vellasco concluía que:

O Estado, para o cristão, é um organismo cuja finalidade está em proporcionar ao homem o seu progresso moral e material, a realização de sua personalidade, o que não será conseguido com a supressão da liberdade. Eis porque aqui insisto aqui na fórmula cristã: 'autoridade, sim; mas com liberdade'. ${ }^{266}$

Mesmo que apresentem acentuado viés humanista-religioso, é possível notar nas exposições de Domingos Vellasco certas expectativas quanto a ampliação da ação do Estado na ordenação da economia, com a condição de que se efetivassem os meios para a participação

\footnotetext{
${ }^{263}$ Anais da Constituinte, Vol. V, p. 10 e 80.

264 VELLASCO, Domingos. Rumos Políticos. Rio de Janeiro: Agir, 1946, p. 39.

265 Ibidem, p. 32.

266 Ibidem, p. 33.
} 
e controle social dos meios de produção. Há aqui indícios, portanto, de que o valorizado programa do trabalhismo britânico, sintonizado com o modelo de Estado de Bem-Estar Social a que subscrevia, permitia não apenas uma apropriação ampla deste modelo, como a definição de metas originais a serem validadas pelo tempo.

Em concordância com parte das críticas ao liberalismo econômico feitas por Vellasco, Jurandir Pires, por sua vez, pronunciou um discurso em que considerava como um ideal a ser alcançado o casamento entre as conquistas preconizadas pelo socialismo e as garantias de liberdade individual presentes no ideário liberal. O que impedia esse casamento, segundo o deputado, era "o crescimento do capital monopolista financeiro, última expressão do liberalismo econômico". ${ }^{267}$ Pires foi mais além, defendendo em plenário a criação de um instrumento regulador da produção sob controle do Legislativo, a fim de evitar as crises cíclicas do capital e incrementar a produtividade e o consumo. ${ }^{268}$ As propostas de Jurandir Pires serão melhor analisadas em um item seguinte.

Pelo fim dos trabalhos da Comissão de Constituição, a Subcomissão de Ordem Econômica e Social debateu a lei que regularia a nacionalização dos bancos de depósito e empresas de seguro estrangeiras. O relator Agamenon Magalhães havia aceito uma emenda de autoria do deputado Adroaldo Mesquita (PSD), que exigia a participação de acionistas brasileiros em tais negócios. A favor da encampação imediata daquele específico setor da economia, Hermes Lima classificou de jacobina e nativista a medida do colega, acrescentando que ela não encerrava nenhum sentido de reforma social. Discorrendo mais sobre o tema, Hermes Lima aproveitou para expor o que seriam as imprecisões recorrentes em torno do termo “nacionalização", argumentado que, se por este se entendia "passar para o domínio do Estado", então tudo estaria "perfeito". Por outro lado, o deputado julgou sem sentido a ideia - certamente lançada por algum colega - de instituir mecanismos legais que, no futuro, garantissem a nacionalização de bancos e empresas já maduros para tal. Segundo Hermes Lima, seria o mesmo que passar uma "carta de ingênuo" aos estrangeiros dar-lhes a perspectiva de que seus empreendimentos passariam às mãos de brasileiros caso estivessem dando bons resultados. ${ }^{269}$

\footnotetext{
267 Anais da Constituinte, Vol. V, p. 10-11.

268 Anais da Constituinte, Vol. IV, p. 204-211.

${ }^{269}$ O capital estrangeiro e a Comissão de Constituição. Correio da Manhã, 15.05.1946, p. 10; Na Comissão de Constituição. Jornal do Brasil, 15.05.1945, p. 6; Aprovado um artigo proibindo a usura. Diário de Notícias, 15.05.1946, p. 3. Garantia à inversão útil dos capitais estrangeiros. O Jornal, 15.05.1946, p. 3.
} 
Ao findar os trabalhos da Comissão de Constituição, Hermes Lima ressentia-se de que o anteprojeto de Carta enviado à apreciação da Assembleia Constituinte não garantia, ao seu ver, instrumentos suficientes para a intervenção do Estado na economia. Insatisfeito com o texto preliminar, cujas medidas classificou como tímidas, Hermes Lima dirigiu-se a seus colegas em plenário na esperança de obter o consentimento da maioria para futuras modificações. Para o deputado, a "timidez" da Comissão de Constituição refletia a preocupação de não impedir que o capital estrangeiro viesse colaborar com o desenvolvimento do país. Hermes Lima argumentou que a intervenção do Estado jamais foi um problema quando não colocava em risco os negócios da classe dominante ou de frações desta, citando, como exemplos históricos, as intervenções no café e o Reajustamento Econômico. Quando, porém, defendia-se a intervenção do Estado em favor "da maior participação das massas nos benefícios da civilização, que hoje tem capacidade de ampliar esses benefícios, porque se funda na técnica e na ciência", levantavase contrário o "grande clamor capitalista". 270 Seguindo seu discurso, Hermes Lima relacionou o tema da intervenção do Estado ao papel que desejava ver conferido ao capital estrangeiro:

O que apenas defendo é que a participação do capital estrangeiro não deve ditar normas à organização da nossa vida econômica. O capital estrangeiro não deve amarrar a nossa economia à categoria de economia suplementar ou assessória de economias alheias.

É justamente contra isso que nós devemos nos bater, porque o capital que assim procede não é conveniente ao progresso da Nação e, sim, elemento que se vem introduzir no país como ponto de fixação de forças internas e externas interessadas na sujeição do povo a um status quo social em que os privilégios da riqueza caracterizam toda a organização.

A esse capital eu denominaria capital explorador. É evidente que, se deixarmos o capital dançar conforme a música que lhe aprouver, não fará mais que exercer a função de drenar lucros. Se, porém, praticarmos uma política social e econômica segura, patriótica e fundada num regime verdadeiramente popular, esse capital desempenhará dentro do pais a função de cooperador, recebendo, ao mesmo tempo, a justa retribuição que não lhe pede ser negada, mas, ao contrário, lhe deve ser assegurada, até com maiores garantias pelo próprio Estado, quando for $\mathrm{o}$ caso, em se tratando de serviços nacionalizados. ${ }^{271}$

Como se nota na passagem acima, por mais que defendesse a estatização de determinados ramos da economia, Hermes Lima não previa impedir a participação na economia nacional do capital estrangeiro ou impor mecanismos legais, porém contraditórios, de futura nacionalização. Pelo contrário, o deputado acreditava que, uma vez domada por mecanismos

\footnotetext{
${ }^{270}$ Anais da Constituinte, Vol. XII, p. 257-258.

${ }^{271}$ Anais da Constituinte, Vol. XII, p. 259.
} 
de planejamento estatal sob o controle popular, a participação do capital estrangeiro seria um componente salutar do desenvolvimento econômico nacional. Por essa perspectiva, o problema central não se configurava em torno de a qual pátria pertenciam os capitais, e sim a sua funcionalidade e a natureza do Estado a qual estariam subordinados - se elitista e permissivo ("entreguista", se diria mais tarde); ou se popular e nacionalista.

Outra disposição subscrita pelo deputado Hermes Lima na Comissão de Constituição foi a da participação dos empregados nos lucros das empresas, ao final, aprovada pela Assembleia Constituinte. ${ }^{272}$ A aplicação deste direito ficaria a cargo das definições da lei ordinária, mas, na prática, a medida se tornaria letra morta, pois nenhuma lei foi aprovada enquanto vigorou a Constituição de 1946. Quando comparadas as Constituições de 1934 e de 1946, verifica-se que a inclusão do item sobre a participação nos lucros representou uma das poucas inovações no que se refere a benefícios sociais. Entretanto, por mais que Hermes Lima tenha defendido tal inovação, o assunto não era ponto pacífico dentro da própria Esquerda Democrática. Na verdade, a discussão interna prolongou-se por alguns anos, tendo a Comissão Estadual de São Paulo assumido posições que apenas concebiam a reivindicação de participação de lucros dentro de um quadro mais abrangente de amadurecimento da luta pelo socialismo. ${ }^{273}$

\subsubsection{O caso da Light}

Quanto às empresas concessionárias de serviços públicos, Hermes Lima posicionou-se veementemente a favor de sua estatização durante as reuniões da Comissão de Constituição que, de uma forma mais limitada, reacenderam a discussão acerca de encampações. ${ }^{274}$ Uma dessas empresas concessionárias de serviços as quais o deputado socialista não concebia que fossem operadas por capitais estrangeiros era a Light. ${ }^{275}$ Paralelamente, coube a seu correligionário, Domingos Vellasco, a relatoria da Comissão Parlamentar encarregada de debater a situação dos trabalhadores da empresa. ${ }^{276} \mathrm{O}$ interessante, nesse caso, foi uma das formas adotadas por Vellasco para reunir informações úteis a esse debate. O deputado solicitou que as comissões estaduais da Esquerda Democrática veiculassem anúncios nos jornais

\footnotetext{
${ }^{272}$ A lei ordinária regulamentará a participação nos lucros. Correio da Manhã, 16.05.1946, p. 14.

${ }^{273}$ A participação nos lucros não leva ao socialismo. Folha Socialista, 05.02.1949, p. 1-2 e 5.

${ }^{274}$ A sessão da Assembleia Constituinte. Jornal do Brasil, 30.08.1946, p. 9.

${ }^{275} \mathrm{Na}$ Comissão da Constituição. Jornal do Brasil, 05.09.1946, p. 6.

${ }^{276}$ Anais da Constituinte, Vol. XII, p. 336.
} 
convidando os funcionários da Light a dirigirem-se às sedes locais do partido para expor suas condições de trabalho a fim de que os dados fossem encaminhados à Assembleia Constituinte. ${ }^{277}$ Tal método parece ser mais uma evidência do reconhecido distanciamento dos socialistas em relação ao operariado, e uma amostra dos “expedientes liberais" levados a cabo pelos parlamentares do partido na tentativa de promover sua política social.

O fato é que a comissão parlamentar referida acima decidiu nomear uma outra, composta por empregados da Light, para aprofundar seus trabalhos. É difícil precisar que parte a Esquerda Democrática tomou na organização dos operários que se incorporaram ao que se chamou “Comissão de Salários” da Light. Da redação do Vanguarda Socialista, vizinha ao Palácio Tiradentes, celebrou-se a decisão como um gesto exemplar de ligação da Constituinte ao trabalhador brasileiro. O entusiasmo, no entanto, logo deu lugar ao repúdio quando a direção da Light decidiu demitir os funcionários membros da comissão. A empresa certamente se valeu do clima repressor imposto à classe trabalhadora na época e da vista grossa do Ministério do Trabalho, conforme denunciado pelo Vanguarda. ${ }^{278} \mathrm{O}$ episódio demonstra o quanto de terreno pedregoso a Esquerda Democrática tinha pela frente em seu objetivo de perseguir uma estratégia que visava à mobilização da classe trabalhadora em torno de um programa socialista submetido às regras de uma democracia limitada.

\subsubsection{Nacionalização versus socialização}

Sem base social e, portanto, longe de qualquer possibilidade efetiva de ao menos reverberar em ampla escala as suas ideias, os parlamentares da Esquerda Democrática vislumbravam uma Carta Magna capaz de garantir os mecanismos de controle da economia nacional como passo primeiro no sentido da futura socialização dos meios de produção. Já no apagar das luzes da Assembleia Constituinte, ao compartilhar da sua visão de mundo, Hermes Lima argumentou que "não é possível desarmar o Estado nesta altura da vida contemporânea e da transformação social que estamos presenciando, do poder de intervir, de nacionalizar ou de monopolizar". Logo em seguida, ao ser interpelado por um colega que objetou ser essa uma teoria nazifascista ou comunista, Hermes Lima respondeu que tanto o nazismo quanto a democracia podem fazer uso de nacionalizações, posto que ambos podem fazer uso da ciência e das técnicas, tudo a depender do sentido em que se lhes emprega. Como caso concreto do

\footnotetext{
${ }^{277}$ Esquerda Democrática comunica-nos. Folha da Manhã, 30.05.1946, p. 12.

${ }^{278}$ A Light demitiu os membros da Comissão de Salários. Vanguarda Socialista, n. 38, 17.05.1946, p. 6.
} 
sentido conferido à palavra "nacionalização", o deputado cita o então recém-nacionalizado Banco da Inglaterra. Com esse exemplo que se pretendeu taxativo, Hermes Lima buscou, inutilmente, convencer seus colegas de que um novo espírito econômico se apossava do "mundo esclarecido". 279

Mas a visão de Hermes Lima acerca de nacionalizações democraticamente orientadas para o bem-estar comum ou, conforme referido acima, como via para o socialismo, sofreria concorrência da própria militância socialista. E seria o grupo do Vanguarda Socialista a se manifestar de forma contrária a ideia de que aos socialistas caberia persistir na exigência da nacionalização dos meios de produção.

O grupo reconhecia que os teóricos do marxismo se preocuparam ao longo de um século em preconizar a nacionalização dos meios de produção como um passo para o estabelecimento do socialismo, tornando quase impossível para seus discípulos se libertarem desse "velho preconceito doutrinário". A questão, porém, estaria no fato de que os mestres da teoria marxista, então em luta contra doutrinas liberais ou contra resquícios do velho regime, não se depararam com "experiências hodiernas" como o fascismo, o nazismo e o bolchevismo. No caso particular da União Soviética, o Vanguarda concebia que ali, após a passagem dos meios de produção à propriedade do Estado, havia se constituído uma "classe dirigente" de burocratas sustentada pela exploração da massa de trabalhadores impedida de manifestação política. Dessa forma, a "burguesia totalitária" soviética, identificada com o aparelho burocrático, manteria seu poder sobre as bases de um "capitalismo de Estado", ${ }^{280}$

Em se tratando do fascismo, o Vanguarda recordava que tanto Hitler quanto Mussolini entraram em desacordo com as burguesias que lhes dedicaram apoio todas as vezes em que pretenderam expandir o domínio do Estado por via de nacionalizações. Assim, após produzir um discurso que de certa forma aproximava-se do mesmo tipo de indagação dirigida a Hermes Lima no plenário da Assembleia, o grupo asseverou:

Quando os fatos se apesentam dessa forma e com essa clareza, é espantoso que ainda haja socialistas capazes de advogar, em nome

\footnotetext{
279 Anais da Constituinte, Vol. XXIII, p. 185-187.

${ }^{280} \mathrm{O}$ artigo que ora se analisa, ao fazer a crítica ao conceito de "capitalismo de Estado", poupa, porém, a Lenin, que de fato cunhou a expressão para descrever a solução encontrada pelos bolcheviques para "salvar" a economia soviética em colapso nos primeiros anos da década de 1920.
} 
precisamente do socialismo (!), a nacionalização dos meios de produção. $^{281}$

Para o Vanguarda Socialista tratava-se de assumir a tarefa de reajustar a doutrina socialista à experiência vivida, para que o socialismo continuasse sendo o impulso criador da classe operária, "o grande anseio de toda a humanidade". Sob a mesma análise, se pelo menos em termos teóricos era questão pacífica entre os socialistas que o Estado deve "definhar" até o ponto de desaparecer, o mesmo não ocorreria - segundo o Vanguarda - quando se esquecia que somente um Estado erguido sobre bases sociais verdadeiramente operárias poderia operar tal transformação de qualidade. Assim, dizia o jornal, a democracia operária tornaria desnecessária as nacionalizações e todos os "perigos" decorrentes dela. Ao Estado operário, sem intervir na economia socializada, caberia o papel de impedir assaltos reacionários de Estados circundantes e de setores internos de burgueses despojados. ${ }^{282}$

Finalmente, o jornal não se furtou em lançar uma crítica ao processo de nacionalizações que começava a ocorrer pouco a pouco no Reino Unido. Alegadamente sob pena de produzir descrédito irremediável ao socialismo democrático, tal processo era percebido pelo grupo do Vanguarda como fadado ao fracasso. Mais cedo ou mais tarde, dizia o Vanguarda, ou a democracia britânica seria solapada pelas nacionalizações, ou estas seriam interrompidas quando extrapolassem suas próprias contradições. Restaria o aprendizado qualquer que fosse o resultado, pelo menos os socialistas do mundo inteiro teriam novos critérios para examinar as relações entre Estado e socialismo. ${ }^{283}$

\subsubsection{Planejamento econômico}

Enquanto no discurso de Domingos Vellasco a crítica ao liberalismo econômico coadunava-se explicitamente com o anticomunismo, no de Jurandir Pires ela se caracterizava pela defesa do planejamento econômico. Voluntária ou involuntariamente, ambos os comportamentos representavam variantes do socialismo internacional do pós-guerra. Como vimos, Hermes Lima também defendia instrumentos de intervenção do Estado na economia, ausentes no anteprojeto elaborado pela Comissão de Constituição segundo o julgamento do deputado. Para Jurandir Pires, no entanto, importava criar formas de delegar ao Legislativo as

\footnotetext{
${ }^{281}$ LOBO, Aristides. Contra a nacionalização dos meios de produção. Vanguarda Socialista, 22.01.1946, p. 2.

${ }^{282}$ Idem.

${ }^{283}$ Idem.
} 
funções do planejamento econômico, para que assim se evitasse a crescente hipertrofia do Executivo. Do contrário, alegava o Jurandir Pires, haveria um indesejável fortalecimento dos monopólios, a exemplo do que teria ocorrido no Estado Novo e seguiria ocorrendo no governo Dutra. $^{284}$

A proposta de Jurandir Pires previa a criação do órgão do "Poder Econômico", a ser exercido por um Conselho de Economia Nacional formado por uma comissão eleita pela Câmara dos Deputados e empenhada na formulação, fiscalização e execução dos planos econômicos. Sua função não seria independente do Legislativo, mas um auxiliar técnico deste, "para quem estuda os problemas na sua base científica, oferecendo solução ao legislador para o julgamento de sua oportunidade política". ${ }^{285}$ Segundo a interpretação de Pires, ao Executivo não caberia mais do que executar o planejamento, entendendo-se o Legislativo como o verdadeiro espaço da autonomia popular e o poder que acompanha a própria evolução da sociedade e de suas necessidades. ${ }^{286} \mathrm{O}$ texto final da Constituição, porém, não conferiu ao Legislativo os poderes reivindicados pelo deputado, limitando-se apenas à criação do Tribunal de Contas, como órgão de fiscalização orçamentária. ${ }^{287}$

De fato, a intervenção de Jurandir Pires foi marcada por um otimismo excessivo em torno do planejamento econômico, acreditando que "as socializações", vistas pelo deputado como necessárias ao progresso, poderiam resumir-se a medidas adotadas pelo alto por mentes capazes e dispostas. Como orientação prévia da política econômica que deveria nortear tais medidas, Pires destacou o imperativo da defesa do mercado interno. Por essa ótica, o problema econômico, além de central, sobrepunha-se a todas as outras manifestações que, segundo o deputado, "não passam de poesia lírica". Com esse entendimento, estaria aberto o caminho para que se obtivesse "pela evolução aquilo que poderia ser alcançado pela revolução". 288

\footnotetext{
${ }^{284}$ Anais da Constituinte, Vol. V, p. 279-281.

285 Anais da Constituinte, Vol. XVI, p. 299-300.

${ }^{286}$ Anais da Constituinte, Vol. XI, p. 460-461; e XII, p. 353.

${ }^{287}$ BRASIL. Constituição Federal de 1946. Artigos 22 e 77.

288 PIRES, Jurandir Apud DUARTE, José. A Constituição brasileira de 1946. Exegese dos textos à luz dos trabalhos da Assembleia Constituinte. v.1. Rio de Janeiro: Imprensa Nacional, 1947, p. 150.
} 


\subsubsection{A atuação de Gilberto Freyre}

Foi o sociólogo Gilberto Freyre, contudo, quem mais se aproximou do ideário do socialismo europeu no que diz respeito à visão acerca do mundo do trabalho. Contraditoriamente, porém, foi ele quem, dentre os membros da Esquerda Democrática, esquivou-se do debate sobre a socialização dos meios de produção. Em discurso bastante celebrado pelo conjunto dos parlamentares constituintes, Freyre logrou reunir a defesa do planejamento econômico, de garantias de liberdade individual e, finalmente, da proteção social ao trabalhador. Nas semanas que antecederam tal intervenção, o deputado Gustavo Capanema (PSD) - que a menos de seis meses havia deixado o cargo de onze anos à frente do Ministério da Educação - havia proposto uma emenda com o seguinte texto: “A ordem econômica tem por base os princípios da justiça social, conciliando a liberdade de iniciativa ou de empresa com a valorização humana do trabalho". Freyre, no entanto, defendeu que o texto fosse alterado para: “A ordem econômica conciliará a liberdade de empresa com a condição humana do trabalho e a proteção social do trabalhador". Para o deputado, a inserção do trecho "proteção social do trabalhador" era o que permitiria, de fato, tornar o trabalho mais humano. De outra forma, o capítulo referente à ordem econômica tornar-se-ia impreciso e generalista, adjetivos que Gilberto Freyre atribuía aos discursos geralmente proferidos por seus colegas. ${ }^{289}$

Por “proteção social”, Freyre se referia tanto ao ambiente em que se realizava a atividade do trabalhador, "como fora dele, isto é, em casa, na comunidade, quando doente, inválido ou velho o trabalhador, considerado também homem social, homem de família, considerados também sua mulher e seus filhos". ${ }^{290}$ E seguia explicando aos colegas as noções que davam origem ao conceito: “"Proteção Social' é expressão já consagrada em sociologia e em legislação social. Na Alemanha pré-fascista era assim que se denominava o departamento de administração pública que coordenava serviços sociais de assistência, higiene, proteção à maternidade e à infância, habitações populares, etc."291

Ao defender determinados mecanismos de planejamento econômico, o autor de Casa Grande \& Senzala não deixou de assinalar que a formação social brasileira possuía em sua evolução histórica especificidades que não poderiam deixar de ser consideradas. Assim,

\footnotetext{
${ }^{289}$ Anais da Constituinte, Vol. XIII, p. 194.

${ }^{290}$ Anais da Constituinte, Vol. XIII, p. 194.

${ }^{291}$ Anais da Constituinte, Vol. XIII, p. 195.
} 
segundo Freyre, o planejamento não deveria estar a serviço de um nacionalismo que excluísse o elemento estrangeiro como fornecedor de braços e ideias assimiláveis à vida nacional em processo contínuo. Tampouco deveria o Brasil deixar de ser para o mundo uma referência em termos de "democracia racial", ao invés de introduzir no seu processo de modernização o que os Estados Unidos tinham de pior: a segregação racial. ${ }^{292}$

Independentemente da visão de raça e cor que Gilberto Freyre legou à sociologia brasileira, registra-se que o tema foi escassamente debatido na Assembleia Constituinte. Em relação à Constituição de 1934, que declarava ilegal privilégios ou distinções de raça, dentre outros, a de 1946 enfatizou que não seria "tolerada propaganda de guerra, de processos violentos para subverter a ordem política e social, ou de preconceitos de raça ou de classe". ${ }^{293}$ Um avanço tímido, em um parágrafo no qual a maioria dos legisladores considerou oportuno diluir a questão do preconceito racial nas preocupações de conservação do regime político. ${ }^{294}$

Formulando política com a cabeça de intelectual, Gilberto Freyre aspirava ainda à possibilidade de trazer a ciência "para a administração, para a organização do trabalho, para a proteção social do trabalhador, para a vida cotidiana das comunidades”. Em sua visão, havia uma distância enorme entre o trabalho dos legisladores e o pensamento técnico e científico especializado. A constatação, no entanto, não deveria motivar a transformação da política em ciência, o que, nas palavras de Freyre, seria extremamente perigoso. O deputado imaginava justamente o contrário: que a interação "entre a arte política e as ciências" possibilitaria a superação tanto do "simplismo marxista-comunista, como do primarismo fascista". 295

\subsubsection{Presidencialismo ou parlamentarismo}

A grande importância atribuída ao trabalho do legislador, como também observado na proposta de Jurandir Pires, não estava desconexa do programa da Esquerda Democrática, para quem o fortalecimento dos instrumentos de representação da sociedade civil e, por extensão, dos poderes legislativos, era um eixo fundamental para o avanço de uma democracia alicerçada nas demandas populares. Das câmaras de vereadores ao Senado Federal, os socialistas definiam

\footnotetext{
${ }^{292}$ Anais da Constituinte, Vol. XIII, p. 199-200.

293 BRASIL. Constituição Federal de 1934. Artigo 113, Parágrafo 1; BRASIL. Constituição Federal de 1946. Artigo 141, Parágrafo 5.

${ }^{294}$ Somente com a Lei Afonso Arinos, promulgada em 1951 por Getúlio Vargas, os atos de discriminação por preconceito de raça ou de cor sujeitar-se-iam à condenação penal.

${ }^{295}$ Anais da Constituinte, Vol. XIII, p. 202.
} 
a valorização dessas instâncias de poder legislativo como prioritárias à disputa pelo Estado. Contudo, se essa constatação vale para a Esquerda Democrática na sua fase inicial, as condições se alterariam ao longo das décadas de 1950 e 1960, quando a agremiação, já renomeada de PSB, realizaria alianças parlamentares tendo em vista a disputa de grandes projetos nacionalestatistas em conjunturas de crescente radicalização política.

Sem ter se detido a fundo ao debate econômico, Nestor Duarte dedicou-se principalmente à defesa do regime parlamentarista, esforçando-se de forma distinta de Jurandir Pires em dar ênfase ao papel do parlamento na vida nacional. A discussão acerca do regime político que a Constituição deveria adotar foi um dos mais acalorados na Assembleia. Ao lado de Raul Pilla (Partido Libertador), baluarte do parlamentarismo no Brasil, Duarte argumentou que os próprios debates cruciais travados na Constituinte conferiam validação ao regime parlamentar, enquanto que o presidencialismo no Brasil carregaria a marca dos excessos do centralismo e das rupturas institucionais. Novamente aqui, o caso inglês é evocado e, dessa vez, como exemplo de longevidade das formas democráticas de governo e de superação de crises políticas sem prejuízo da normalidade institucional. ${ }^{296}$

Durante seu discurso, Nestor Duarte seria aparteado pelo próprio Hermes Lima, que atribuiu os males do presidencialismo não ao regime propriamente dito, mas aos vícios da cultura política. Duarte chegou a citar alguns problemas do parlamentarismo britânico, em que as divergências políticas por vezes extrapolavam a boa condução dos debates. Lá também a cultura política deveria estar sujeita à evolução permanente, argumentou o deputado. ${ }^{297}$ Cabe lembrar que, durante a Primeira República, João Mangabeira, ao lado de Rui Barbosa, havia sido um ferrenho defensor do presidencialismo no Brasil. Rui Barbosa, inclusive, destacou-se na formulação da Constituição de 1891, a primeira do regime republicano e referência constante para os constituintes de 1946. Para Hermes Lima, assim como para João Mangabeira, o caminho para que o presidente da República não tivesse de contar com a aquiescência das Forças Armadas para chegar ao termo de seu mandato ou evitar rupturas institucionais, estaria no fortalecimento do Supremo Tribunal Federal. ${ }^{298}$

\footnotetext{
${ }^{296}$ Qual regime político que se deve adotar na nova Constituição? Jornal do Brasil, 20.07.1946, p. 10.

297 Anais da Constituinte, Vol. I, p. 252-253.

298 BALEEIRO, Aliomar. A Constituinte e a Constituição Federal de 1946. In: BALEEIRO, Aliomar; SOBRINHO, Barbosa Lima. Constituições brasileiras: 1946. Brasília: Senado Federal, 2001, p. $20-21$.
} 
Com a disposição geral dos constituintes de não alterar as linhas fundamentais da tradição constitucional do Brasil republicano, o parlamentarismo seria derrotado por ampla maioria. O tema seria retomado com maior vigor na crise política de 1961, quando tentou-se impedir a posse do vice-presidente eleito João Goulart. Foi Raul Pilla o responsável pela elaboração da emenda que instituiu uma "solução parlamentarista" sui-generis, impedindo temporariamente uma crise institucional de maiores proporções. Ironicamente, antes que o plebiscito de 1963 pusesse fim ao parlamentarismo, Hermes Lima, já então membro do PTB de Goulart, seria o derradeiro primeiro-ministro do Brasil.

\subsubsection{Reforma agrária}

Outra questão com que se ocupou a bancada da Esquerda Democrática foi a da reforma agrária, tema espinhoso levando-se em conta a composição social da Assembleia Constituinte. ${ }^{299}$ Ao mesmo tempo, este era um assunto cuja discussão era inevitável, pois perpassava diferentes conjunturas históricas sem que houvesse uma definição clara acerca das atribuições do Estado com relação à propriedade da terra. A Constituição de 1934, de curta vigência, havia consagrado certo avanço em relação ao direito de propriedade, ao condicionála aos interesses sociais e coletivos: "É garantido o direito de propriedade, que não poderá ser exercido contra o interesse social ou coletivo, na forma que a lei determinar, mediante prévia e justa indenização". ${ }^{300}$ Como a legislação tornou-se letra morta, jamais servindo de instrumento para alterar a configuração da estrutura agrária brasileira, o debate haveria mesmo de se reacender em 1946.

E foi o mais iminente orador socialista quem tomou a frente para buscar introduzir a questão agrária no cerne dos problemas sociais e econômicos do país. Hermes Lima identificava na estrutura agrária a raiz das péssimas condições de vida do povo brasileiro. Um problema que teria sido herdado do modelo colonial, voltado para fora, incapaz de criar um mercado interno para que o trabalhador desse cabo do seu desenvolvimento humano e de, consequentemente, ter

\footnotetext{
${ }^{299}$ Segundo Almino, 19,2\% dos constituintes desempenhavam a função de proprietários rurais como ocupação principal. Levando-se em conta os que também eram proprietários rurais mas tinham outras ocupações como principais, o percentual sobe para 24\%. Cf. ALMINO, João. Era uma vez uma Constituinte: lições de 1946 e questões de hoje. São Paulo: Brasiliense, 1985, p. 71. Evidentemente, o índice não é suficiente para conclusões acerca de que posicionamento cada constituinte em particular mantinha sobre a "questão agrária", tampouco quanto ao "espírito coletivo" que ditou o debate. Além disso, poder-se-ia supor que outros tipos de proprietários e/ou profissionais de outra natureza também possuíam interesses ligados diretamente ao dos grandes proprietários rurais.
}

${ }^{300}$ BRASIL. Constituição Federal de 1934. Artigo 113, Parágrafo 17. 
meios de reivindicar outra sorte para si. Hermes Lima acentuou a gravidade da situação enfatizando que a maioria da população era, à época, de trabalhadores rurais. Feito o preâmbulo, o deputado argumentou que não bastariam progressos no sentido de mera "concessão de direitos formalmente políticos" àqueles trabalhadores. A seu ver, a Constituinte não deveria se deter apenas a essa medida, sob pena de perpetuar a situação exposta. Daí, Hermes Lima defendeu que a Constituição provesse os instrumentos necessários para a reforma agrária, sem que a solução dos problemas relacionados à descomunal concentração de terras ficasse a mercê da legislação ordinária que tratasse cada caso em particular. ${ }^{301}$

O que importa, para incorporar a nossa vasta população rural aos benefícios de uma organização econômica mais adiantada do ponto de vista social e técnico, é, antes, consagrar no texto da Constituição a nacionalização das terras não exploradas ou daquelas cuja utilização desatenda ao interesse público, a partir das zonas populosas; o que importa é permitir a instalação de cooperativas de trabalhadores; o que importa é chegar à abolição do aforamento, à desenfeudação da propriedade, como já dizia Rui Barbosa. \# O que importa é consagrar a possibilidade do parcelamento das terras do país em lotes para a posse individual, onde não seja possível a instalação de cooperativas de trabalhadores. ${ }^{302}$

Sobre o que Hermes Lima chama de "desenfeudação da propriedade", intui-se que, na perspectiva do deputado, ela ocorreria ao passo que a distribuição de terras fosse acompanhada da integração das novas unidades produtivas às demandas de consumo das áreas urbanas, diminuindo-se, assim, a pressão exercida na economia pelos elementos de atraso da concentração fundiária. Como o conceito de nacionalização aparece novamente no discurso de Hermes Lima, este trata de observar que, pelo termo, entende-se nesse caso "a transferência para o domínio da nação". 303 Difere-se, pois, da ideia de estatização, uma vez que os trabalhadores rurais se incorporariam à economia sem estar submetidos à gestão estatal direta.

Hermes Lima insistia que a resolução do problema agrário era condição fundamental para "uma verdadeira política industrial". Nessa análise, uma vez realizada com sucesso, a reforma agrária viabilizaria o incremento da produtividade industrial e, por conseguinte, o aumento da remuneração do operário. O operário melhor remunerado, por sua vez, estaria apto a investir na própria instrução e dedicar à produção o progresso técnico por ele adquirido. ${ }^{304}$

\footnotetext{
${ }^{301}$ Anais da Constituinte, Vol. VI, p. 205-212 e 281-288.

302 Anais da Constituinte, Vol. XII, p. 258.

${ }^{303}$ Idem

${ }^{304}$ A sessão da Assembleia Constituinte. Jornal do Brasil, 10.04.46, p. 9.
} 
Ainda que esboçasse na tribuna um esquema aparentemente simplista - cujas bases, porém, amadureceriam e ganhariam espaço nos anos posteriores - Hermes Lima buscou ir além da mera exposição dos intrincados problemas econômicos brasileiros e dos motivos de sua perpetuação. ${ }^{305}$ Um dia após ter defendido seu modelo de reforma agrária, o deputado voltou à tribuna para reforçar que seus argumentos se orientavam no sentido de dar condições às massas de participar autonomamente da política nacional. Hermes Lima criticou a atuação da maioria dos partidos que apenas se aproximavam dos trabalhadores por meio de máquinas políticas e eleitorais, sem jamais conseguir alinhar seus interesses com os interesses populares. E, mais do que isso, nada faziam aqueles partidos para que o povo atuasse "militantemente organizado para a defesa de seus interesses". Hermes Lima considerava que a legislação trabalhista após 1930 ampliou direitos, ainda que de forma demagógica, mas não alterou o estado de subserviência do trabalhador. Por fim, o deputado argumentou que nenhum de seus colegas parlamentares se sujeitava a sustentar discursos defendendo a ordem existente e que, na teoria, todos se comportavam implícita ou explicitamente como socialistas. De maneira que "o capitalismo já deverá dar lugar ao socialismo, como vem ocorrendo, e é necessário, portanto, superar a dicotomia entre postura intelectual e prática política".306

Após a promulgação da Constituição de 1946, o PSB entraria em uma nova etapa de definições estratégicas, que foram sendo realizadas conforme novos temas eram refletidos e novas propostas foram sendo lançadas pelos socialistas à política brasileira.

\footnotetext{
${ }^{305}$ As bases a que nos referimos circunscrevem-se no pensamento desenvolvimentista do pós-Estado Novo. Tal corrente de pensamento, diversa em seu interior, opôs-se ao programa liberal que, por sua vez, experimentara algum prestígio logo após a queda do ditador. Cf. BIELSCHOWSKY, Ricardo. Pensamento econômico brasileiro: o ciclo ideológico do desenvolvimentismo. 5.ed. Rio de Janeiro: Contraponto, 2004, Parte II, Item 10.

${ }^{306}$ A sessão da Assembleia Constituinte. Jornal do Brasil, 11.04.46, p. 9.
} 


\section{Capítulo IV - Em busca de uma política socialista e democrática: o PSB entre 1947 e 1950}

No período que decorre entre o fim da Constituinte de 1946 e as eleições presidenciais de 1950, o PSB tentou demarcar melhor o seu espaço e responder às inúmeras inquietações provocadas por um ambiente politicamente hostil ao movimento operário e às liberdades democráticas. A fim de intervir nesse cenário, os socialistas dedicaram-se a debater e encaminhar propostas que visavam reformar a legislação trabalhista vigente, de modo a pôr fim à estrutura sindical corporativista herdada do Estado Novo. Para o PSB, conferindo maior autonomia aos trabalhadores, seria possível imprimir uma política sindical socialista como suporte indispensável para a futura socialização da economia.

Nesse ínterim, os socialistas envolveram-se na campanha pelo monopólio estatal da exploração do petróleo, fazendo dela um momento oportuno para definir a política do PSB acerca dos seus objetivos estratégicos. Ao distinguir os conceitos de nacionalização e de estatização o partido buscou diferenciar-se de outras correntes políticas menos críticas ao papel do capital nacional no conjunto da economia brasileira.

Confiante na viabilidade de seu programa, o partido preferiu manter alguma distância da pregação democrática tal como sustentada por setores liberal-conservadores. Estes visavam atingir sobretudo o PCB, em uma campanha que previa extirpar os comunistas da vida política nacional. Ao mesmo tempo, os socialistas esforçaram-se por diferenciar-se dos comunistas simpáticos à União Soviética, com os quais não estabeleceram compromissos e contra os quais mantiveram uma posição crítica. O conceito do "socialismo democrático", então em voga no ideário dos partidos socialistas europeus, tornou-se uma importante arma retórica e programática dos socialistas brasileiros.

\subsection{A mudança de nome}

A questão da mudança de nome da Esquerda Democrática para Partido Socialista Brasileiro estava prevista desde os debates da I Convenção Nacional do partido. Como vimos no capítulo anterior, a discussão esteve em primeiro plano naquela ocasião, o que demonstra que o que estava em jogo eram definições importantes acerca do futuro do partido. Reivindicar o termo "socialista" poderia significar uma declaração de que o partido encampava a ideia de 
ser no Brasil um representante da tradição socialista internacional. Poderia significar também abrir mão das inúmeras significações que o difuso nome "Esquerda Democrática" poderia suscitar. Já o nome "Partido Socialista", pelo menos em tese, teria o poder de repelir ou constranger membros menos inclinados a um programa decididamente socialista, embora não fosse suficiente para dissolver as ambiguidades ideológicas no interior da vida partidária.

Os socialistas mais radicais da Comissão Estadual de São Paulo foram os principais proponentes da mudança de nome, alcançando, enfim, a vitória de sua proposta na II Convenção Nacional da Esquerda Democrática, realizada no Rio de Janeiro, em abril de 1947. Na convenção, além da adoção do novo nome, decidiu-se pala manutenção do programa aprovado no ano anterior, à exceção da supressão do item que defendia o direito de divórcio. Neste ponto, como vimos, venceu a posição encabeçada pelo católico Domingos Vellasco, após acirrado debate (ver Capítulo II, item 2.2).

Para Antonio Candido, membro do grupo paulista, o PSB superava a fase dos pequenos grupos que se uniram durante a fase de formação da Esquerda Democrática, tornando-se um partido mais homogêneo e mais fortalecido para concorrer com o "trabalhismo potencialmente fascista" do PTB, que sequer poderia ser considerado ao menos uma expressão de um "socialismo degenerado". Ainda segundo Candido, a classe trabalhadora teria no PSB uma opção à política de colaboração de classes do PCB que, submetido aos interesses estritos da política soviética, e sem nenhuma capacidade de desenvolver a consciência revolucionária nas massas, poderia apenas desenvolver ambientes propícios ao golpismo. ${ }^{307}$

Após a realização da II Convenção Nacional da Esquerda Democrática, o grupo do Vanguarda Socialista publicou um artigo de um observador correspondente de um jornal socialista dos Estados Unidos. O autor destacou nunca ter havido no Brasil um partido verdadeiramente socialista e democrático, em que pese as tentativas feitas nesse sentido durante a Primeira República. A Esquerda Democrática teria sido, no entanto, um intento "mais ou menos genuinamente socialista", mas com noções apenas básicas a respeito do socialismo. Além de carecer de penetração entre os trabalhadores, prosseguia o jornalista, os membros da Esquerda Democrática temiam afrontar o PCB, opinião repetida com frequência também pela imprensa nacional da época. Para o observador norte-americano, o grupo do Vanguarda - já em fase de integração ao PSB - seria a alternativa mais capaz de formular diretrizes socialistas

${ }^{307}$ CANDIDO, Antonio. A situação brasileira. Folha Socialista, n.1, 27.11.1947, p. 1-2. 
ao partido. ${ }^{308}$ Assim, ao dar voz a um observador estrangeiro, o Vanguarda Socialista seguia tentando ocupar um lugar de liderança no PSB, o que dá mostras de que a disputa interna estava aberta e o partido longe de alcançar um avançado grau de homogeneidade ideológica.

Noticiando os desdobramentos da II Convenção Nacional da Esquerda Democrática, um artigo do jornal Correio da Manhã disse que, segundo se propalava, o PSB entrava em uma nova fase de reorganização, deixando de ser somente "um programa e um clube". O partido pretendia, segundo a matéria, desconstruir seu apático comportamento diante do comunismo, o que lhe teria custado a desconfiança popular. Na sequência, sugere-se que a Esquerda Democrática havia caído no erro de nutrir esperanças de ser a mediadora entre o comunismo e a democracia. Tal equívoco não teria sido exclusivo dos socialistas brasileiros, uma vez que estes absorveriam os mesmos ressentimentos enfrentados pelos partidos socialistas estrangeiros que ainda não teriam encontrado uma posição própria com relação ao bolchevismo. $\mathrm{O}$ artigo concluiu que os problemas sociais de um país representavam conflitos internos que não podiam ser resolvidos procurando desviar-se para o campo das hegemonias estrangeiras, e que, "na luta contra o comunismo, a democracia deve ser o substantivo e não apenas um adjetivo mais ou menos vago, impreciso".309

Evidentemente, a burocracia estatal e a grande imprensa estavam na época empenhadas na cruzada anticomunista conduzida pelo governo Dutra. Todo o debate em torno do PSB desenrolava-se sob o clima do cerco ao PCB, do qual os próprios socialistas, por tabela, não estavam imunes. O julgamento da validação do registro do PSB pelo Supremo Tribunal Eleitoral (STE) acabou tendo contornos dramáticos. Por quatro votos a dois, o registro foi deferido, não sem que antes houvesse um intrigante processo de deliberações entre os ministros encarregados de julgar o caso. O relator louvou o fato do PSB ter deixado de se manifestar a favor do divórcio em seu programa, adequando-se, segundo ele, às tradições cristãs brasileiras. Considerou, ainda, que o programa do PSB não colidia com o "espírito democrático", apresentando, na verdade, "certo caráter de timidez". ${ }^{310}$ Dos dois ministros que votaram contrários ao registro, um deles quis condicionar a aprovação à retirada do programa da parte referente à progressiva socialização dos meios de produção. O outro gostaria de ver acrescido um dispositivo que ressalvasse que eventuais desapropriações fossem feitas mediante

\footnotetext{
308 ALEXANDER, Robert A. Inicia-se o trabalho por um Partido Socialista no Brasil. Vanguarda Socialista, 18.04.1947, p. 1 .

${ }^{309}$ A Esquerda Democrática. Correio da Manhã, 23.04.1947, p. 4.

${ }^{310}$ Deverá ser julgada hoje a questão dos mandatos comunistas. Correio da Manhã, 29.07.1947, p. 14.
} 
indenização prévia e justa, em dinheiro. Dentre os ministros que votaram favoráveis, além do relator, houve um que considerou que a interpretação dos dispositivos constitucionais não poderia se fechar a ideias novas que "interessam ao mundo e que queiram ou não os homens de hoje, terão de ser vitoriosas um dia". Um outro, ainda, declarou que o programa não estava em conflito com o pensamento dos constituintes de 1946, e que o partido se comprometia a defender suas ideias dentro do limite da lei e com respeito ao eleitorado. E, por fim, o ministro que conferiu o decisivo voto pela aprovação declarou que "a Constituição de 46 não adotou o regime individualista e capitalista em que os pobres não possam se defender na luta pela vida". Este último lembrou ainda que a própria Constituição garantia a propriedade, mas condicionada ao bem-estar social. ${ }^{311}$

\subsection{Socialistas versus comunistas}

Reiteradamente, a grande imprensa buscou jogar o PSB contra o PCB, reclamando junto aos socialistas posicionamentos mais enérgicos em relação ao "totalitarismo comunista". Entre os anos de 1947 e 1948, a perseguição aos comunistas atingiu o seu auge e, para o PSB, coube a tentativa de assegurar o tênue equilíbrio de se manter crítico ao comunismo e ao mesmo tempo preservar a defesa de liberdades democráticas e de organização, sem, no entanto, fazer coro com os apelos repressores daqueles tempos - que atribuíam ao PCB um risco à manutenção da democracia recém-conquistada. Enquanto o PSB caminhasse a passos lentos buscando a confiança dos trabalhadores para a efetivação do seu programa reformista, não havia razões para que o partido pudesse produzir temores em qualquer concorrente à direita do espectro político.

No final de 1946, Hermes Lima e Carlos Lacerda protagonizaram um caloroso debate na imprensa acerca de qual seria a equidistância “ideal” entre socialistas e comunistas. Fora das tribunas políticas, Lacerda não foi o único a instigar o ânimo dos socialistas, mas talvez tenha sido o mais ardiloso ao fazê-lo. Além da costumeira crítica à suposta passividade dos representantes socialistas em relação ao $\mathrm{PCB}$, o jornalista considerou que tal omissão já pecava pelo anacronismo, uma vez que partidos socialistas como o francês e o alemão já haviam se posicionado em favor da democracia e do socialismo contra a ditadura do proletariado e contra os atos da União Soviética no Leste Europeu. ${ }^{312}$ Em outra oportunidade, Lacerda declarou:

\footnotetext{
${ }^{311}$ Concedido registro ao Partido Socialista Brasileiro. Correio da Manhã, 07.08.1947, p. 12.

${ }^{312}$ LACERDA, Carlos. O riacho que transbordou. Correio da Manhã, 29.11.1946, p. 2.
} 
"Enquanto os socialistas não se dispuserem a explicar ao povo que o Partido Comunista é um partido russo, com objetivos russos, e que a Rússia não é socialista, nem os socialistas terão autoridade nem o povo se libertará do Partido Comunista".313

Em resposta, Hermes Lima declarou que na própria Constituinte os socialistas deram demonstrações de total independência político-partidária, o que não facultaria ninguém a chamá-los "linha auxiliar do PCB". Contudo, segundo o deputado, mesmo declarando-se contrária ao comunismo pró soviético, a Esquerda Democrática - o partido ainda não havia trocado de nome - continuaria a reafirmar que não comungava com o liberalismo econômico, pois que entendia este como a fonte das desigualdades sociais e como um conceito que a muitos interessava fazer confundir-se com a democracia. Por conseguinte, Hermes Lima reafirmava que a progressiva socialização dos meios de produção, "por meio da legalidade e por desejo da maioria, tendo a democracia como ideal norteador", diferenciava a Esquerda Democrática do PCB e dos partidos conservadores. Na perspectiva de Hermes Lima, a tática de chamar a Esquerda Democrática de "linha auxiliar do PCB" provinha, antes de tudo, dos interesses conservadores de "comprometer a esquerda nos meios populares não proletarizados funcionários, empregados, pequenos e médios comerciantes, e nas profissões liberais". O interesse dos socialistas, segundo Hermes Lima, seria o de formar o partido "mais poderoso que qualquer outro", sem prejuízo de sua vocação de "partido social-democrata autônomo, independente do pensamento comunista". Hermes Lima não deixava de reconhecer que havia marxistas na Esquerda Democrática, julgando-os como necessários ao partido ao ajudarem a desenvolver o pensamento socialista. Por fim, o líder socialista declarou que seu partido não se prestaria à campanha anticomunista, e lembrou aos seus adversários que o maior anticomunista foi Hitler, com quem os democratas jamais poderiam deixar-se confundir. ${ }^{314}$

É difícil supor que socialistas e comunistas tivessem motivos para oporem-se uns aos outros no mesmo grau de dramaticidade como ocorreu em determinadas regiões do mundo. No Brasil, exceto quando a oposição acalorada entre ambos se confinava às ideias, ou em eventuais debates em plenários, os socialistas não possuíam apoio suficiente para causar um choque mais contundente entre as duas correntes. No entanto, vale mencionar uma provocação feita por Luís Carlos Prestes que, em declaração à imprensa, alfinetou os socialistas ao dizer que "em todo o

\footnotetext{
${ }^{313}$ LACERDA, Carlos. Novembro em Moscou e no Rio. Correio da Manhã, 26.11.1946, p. 2.

${ }^{314}$ LIMA, Hermes. A Esquerda Democrática e o Partido Comunista. Diário de Notícias, 29.11.1946, p. 7.
} 
país onde haja dois partidos se reclamando do operariado, um está a serviço da burguesia - e só o comunista defende o trabalhador". 315

Na verdade, chegou-se mesmo a aventar uma possível aliança eleitoral entre comunistas e socialistas para o pleito de 1947. Nada de muito explícito, nada que tenha merecido larga atenção da imprensa. Aliás, em artigo já citado, é o próprio Lacerda quem sugere que às lideranças socialistas seria preferível poupar críticas ao PCB contando com eventuais acordos eleitorais futuros. ${ }^{316}$ Não há evidências de que os socialistas estivessem dispostos a confirmar a sugestão provocativa do jornalista. Contudo, uma vez perguntado sobre qual postura o PCB tomaria na eleição para a terceira senatoria do Distrito Federal, Prestes teria sugerido que os comunistas teriam um candidato em comum com outro ou outros partidos. E quando perguntado se esse candidato seria João Mangabeira, presidente da Esquerda Democrática, Prestes restringiu-se a fazer referências elogiosas ao jurista baiano. ${ }^{317}$

Em sua coluna no jornal Diário de Notícias, o socialista Osório Borba procurou responder pelo ângulo da conjuntura internacional às "muitas perguntas" que recebia sobre se a Esquerda Democrática poderia ser considerada comunista. Além de reiterar, uma vez mais, o compromisso do partido com o gradual processo de socialização dos meios de produção, Borba declarou que confundir os socialistas com os comunistas seria "um disparate igual ao de procurar se confundir, por exemplo, na França, o partido de Leon Blum, ou na Inglaterra o de Harold Lasky, com o Partido Comunista”. Lembrou ainda que a Esquerda Democrática foi fundada na luta pela democratização em um campo oposto ao do PCB. ${ }^{318}$

Em síntese, enquanto espraiava-se o anticomunismo na política brasileira, o PSB sofreu pressões à esquerda e à direita que certamente lhe trouxeram algum ônus. Para defender-se das acusações de "linha auxiliar do PCB", os socialistas contra-argumentavam se dizendo vítimas de uma tática liberal-conservadora para desestabilizar o protagonismo político de qualquer movimento de esquerda. Por outro lado, sentindo-se na obrigação de firmar sua posição ideológica, os socialistas tentavam deixar claras as suas diferenças com o comunismo, seja no plano nacional ou internacional. Em um cenário de repressão aberta promovida pelo governo

\footnotetext{
${ }^{315}$ Quisling no reino da Dinamarca. Jornal do Brasil, 27.03.1946, p. 2.

${ }^{316}$ LACERDA, Carlos. O riacho que transbordou. Correio da Manhã, 29.11.1946, p. 2.

317 Os comunistas e os governos estaduais. Correio da Manhã, 23.10.1946, p. 1.

318 BORBA, Osório. O Partido Socialista. Diário de Notícias, 18.01.1947, p. 7.
} 
Dutra contra o sindicato e os comunistas, tudo parecia conspirar para que o PSB permanecesse debatendo política como um clube de ilustres cidadãos apartados da dinâmica social.

\subsection{Os socialistas e a cassação do PCB}

Com o cerco se fechando contra os comunistas, o PSB adotou uma linha dupla de intervenção - e muitas vezes ambígua - que dizia respeito, por um lado, à defesa da ordem democrática e das instituições estabelecidas e, por outro, às reivindicações por liberdades políticas e de organização. De um lado, porque a um partido, que desejava chegar ao poder sem abalar as regras do jogo, interessava endereçar críticas àqueles que, segundo se imaginava, concorriam para a corrosão dos pilares da ordem liberal. Por outro lado, interessava igualmente aos socialistas protestar contra as arbitrariedades perpetradas pelo governo sob a claque de uma constelação de setores liberal-conservadores. Tais críticas e protestos foram sistemáticos, demonstrando o interesse de o PSB prezar pelo legalismo como linha geral de conduta.

Ainda em 1946, por ocasião da dura repressão a um comício do PCB - o Massacre do Largo da Carioca - Hermes Lima declarou que os comunistas agiram como provocadores ao realizar a atividade em local vetado pela polícia, acrescentando que esta, por sua vez, havia sido “estúpida” por sua ação desmedida. ${ }^{319}$ Nesse caso específico, o legalismo defendido pelo líder socialista prevalecia até mesmo diante do fato de o governo e a polícia política - afora os elementos provocadores “oficiosos' - estarem cumprindo sua agenda de arbitrariedades que buscava tornar impossível qualquer manifestação política de caráter popular.

Quando o governo decidiu fechar a Juventude Comunista em abril de 1947, os socialistas emitiram opiniões divergentes. No Congresso, Hermes Lima declarou que o PSB era favorável ao fechamento, sob o argumento de que menores de 18 anos não podiam ser objeto de enquadramento partidário, pois corriam o risco de sofrer perturbações na formação pedagógica e de se tornarem arma da doutrinação totalitária. ${ }^{320}$ Durante seu discurso, Hermes Lima foi apartado algumas vezes pela bancada comunista com invocações à democracia. $\mathrm{O}$ deputado socialista respondeu que não precisava de lições dos comunistas para traçar sua linha democrática e que, por falta de inteligência, os comunistas estavam sacrificando a vida

\footnotetext{
319 Anais da Constituinte, Vol. X, p. 189.

${ }^{320} \mathrm{Na}$ Câmara dos Deputados. Jornal do Brasil, 19.04.1947, p. 6. O curioso é que a Esquerda Democrática tinha em seus organismos um grupo denominado “Grupo Pré-universitários”. Ver Notícias políticas. Diário de Notícias, 05.11.1946, p. 4.
} 
democrática do país. Finalizando seu discurso, Hermes Lima declarou-se contrário ao fechamento do PCB, pois "que este já começava a declinar diante do julgamento do povo". 321 A postura de Hermes Lima foi prontamente criticada pelo Vanguarda Socialista, que considerou contraditório opor-se ao fechamento do PCB, mas ser favorável ao fechamento da Juventude Comunista. Para o Vanguarda, os socialistas também não poderiam abrir mão de organizar sua juventude. Segundo o grupo, a decisão tomada pelo governo, além de ferir a democracia e o livre direito de associação, tinha o propósito de "combater ainda o ímpeto construtivo já escasso na juventude". Afinal, concluiu-se, a burguesia queria redimir-se de não ter força e argumentos para atrair a juventude para a defesa do status quo. ${ }^{322}$

A sintonia entre os socialistas foi um tanto maior quando se tratou apenas do fechamento do PCB. A batalha judicial que culminou com a cassação do registro do partido, terminou no dia 7 de maio de 1947. Na mesma data o Ministério do Trabalho ordenou o fechamento da Confederação Geral dos Trabalhadores do Brasil e decretou a intervenção em diversos sindicatos. Nos dias seguintes, a sede do PCB foi lacrada. Na Câmara, a reação da bancada do PSB foi imediata, condenando o fechamento do PCB e as intervenções ministeriais. ${ }^{323}$ Domingos Vellasco, que assistiu ao julgamento do STE, disse preferir a existência legal do $\mathrm{PCB}$, pois seu fechamento desencadearia uma sequência de atos reacionários. ${ }^{324}$

No entanto, apesar de protestar pelo ocorrido, o PSB se posicionou no Congresso de modo a aceitar a decisão e declarando respeito à autoridade do STE para julgar o caso. O partido lamentava que o PCB tivesse sido cassado por entender que suas ações se desenvolviam até então dentro da ordem, e acreditava que todos os partidos e o próprio regime democrático perdiam um pouco de liberdade com a decisão. O PSB clamava para que os democratas reagissem de forma "serena", para que uma sentença não viesse a dar margem para atos de arbítrio e de força que "apunhalam a democracia a pretexto de salvá-la".325

A posição manifestada pelo Vanguarda Socialista foi diferente. Estava claro para o grupo que a cassação do PCB significava uma decisão contra a classe trabalhadora e não um mero ato jurídico. Em seu editorial, Mario Pedrosa atribuiu à grave crise econômica um

\footnotetext{
${ }^{321}$ Sejam mais inteligentes e menos comunistas. Correio da Manhã, 19.04.1947, p. 12.

${ }^{322}$ Mocidade e política. Vanguarda Socialista, n. 87, 25.04.1947, p. 1-2.

${ }^{323}$ Contra o fechamento do PCB, Correio da Manhã, 07.05.1947, p. 12.

${ }^{324}$ O julgamento do Partido Comunista. Folha da Noite, 07.05.1947, p. 2.

${ }^{325}$ Fechadas pela polícia as sedes dos comitês e células do Partido Comunista. Diário de Notícias, 10.05.1947, p. 7.
} 
acirramento da luta de classes com consequências potencialmente explosivas. Nesse cenário, desfazia-se o sonho dos comunistas de se infiltrarem nos cargos públicos e, em aliança tática com os "magnatas da indústria monopolizada nacional", atingir seu objetivo estratégico do "capitalismo de estado" - tipologia com a qual Pedrosa e também os socialistas de São Paulo caracterizavam o Estado soviético. Assim, uma vez que a polícia não podia sozinha desfazer a confiança das massas no PCB, o ato do poder judiciário veio em socorro para tentar arrefecer essa confiança. Pedrosa protestava, ainda, contra a alegação "oficial" de que a situação de penúria das massas era agravada por agitadores comunistas, anarquistas e socialistas. Por fim, o Vanguarda fazia um chamado para a luta nas ruas em defesa das liberdades democráticas conquistadas pelos trabalhadores, ainda que limitadas. ${ }^{326}$

Quando na primeira semana de julho de 1947, o STE decidiu cassar os mandatos dos comunistas, a bancada socialista no Congresso entendeu que dessa vez tratava-se de uma ação inconstitucional. Para os parlamentares do PSB, seja qual fosse a situação jurídica do PCB questão já então julgada pela Justiça Eleitoral - os votos obtidos pelo partido eram irrevogáveis, pois que exprimiam a vontade soberana do eleitorado. ${ }^{327}$

A caça às bruxas que se estendeu por meses não poupou o PSB de dar frequentes explicações à justiça e à imprensa. Em um caso que alcançou certa visibilidade, um alto funcionário do Instituto do Sal foi demitido sob alegação de "desenvolver atividades comunistas". Mesmo provando-se que o "acusado" pertencia às fileiras socialistas, sem envolvimento pregresso com o PCB, manteve-se a sua exoneração. Expondo o caso na Câmara dos Deputados, Hermes Lima indagou os colegas se os funcionários públicos poderiam ficar à mercê dos "humores" do Executivo. ${ }^{328}$ Alguns dias depois, em setembro de 1947, os dirigentes do PSB viram-se na obrigação de responder a uma nota publicada na imprensa, que se equivocara ao incluir os socialistas Hermes Lima, Domingos Vellasco e Castro Rebelo na lista de intelectuais que outrora teriam atuado no PCB. No desmentido, os socialistas afirmaram que os três nunca fizeram parte do PCB, e que além disso, "foram fundadores da Esquerda Democrática que, sob inspiração de princípios políticos, tinha o objetivo imediato de dar apoio

\footnotetext{
${ }^{326}$ PEDROSA, Mario. O FECHAMENTO DO PCB não é um erro judiciário - é um crime político! Vanguarda Socialista, n. 89, 09.05.1947, p. 1-2.

${ }^{327}$ Recusa a Câmara a pronunciar-se sobre a cassação de mandato dos comunistas. Folha da Manhã, 04.07.1947, p. 8.

${ }^{328}$ O dia político. Diário de Notícias, 09.09.1947, p. 8.
} 
à candidatura de Eduardo Gomes". ${ }^{329}$ A saia justa, portanto, foi contornada com a simples negação e decorada com vivas à memória da campanha do Brigadeiro. Uma saída nada honrosa, tendo em vista não só os compromissos do PSB com a liberdade política, sequer mencionados, como também pelo fato de que boa parte de sua militância era egressa do PCB.

No mês seguinte, o governo Dutra rompeu relações diplomáticas com a União Soviética. O rompimento, como se sabe, significou historicamente uma declaração de alinhamento do governo brasileiro ao bloco liderado pelos EUA no alvorecer da Guerra Fria. Entretanto, os eventos que marcaram tal desfecho e, principalmente, a percepção que deles tiraram os socialistas brasileiros, são dignos de menção. Ao final de uma trama obscura que envolveu troca de notas de protesto entre embaixadas, e em que as partes reclamaram tratamentos consulares desiguais e declarações desrespeitosas na imprensa de cada país, o rompimento foi anunciado no dia 21 de outubro. Sem delongas, Hermes Lima subiu ao púlpito da Câmara para declarar que o PSB considerava que o governo agiu dentro de sua competência legal ao romper relações com a União Soviética. Nesse sentido, era importante defender o nome e a dignidade do país após o evento da recusa pelos soviéticos de uma nota enviada pelo Itamaraty. Hermes Lima argumentou, entretanto, que não havia motivos para que qualquer pessoa "de espírito verdadeiramente democrático" e desejoso da paz mundial comemorasse o incidente. Em resposta a uma provocação prévia do PCB, Hermes Lima disse não ver na ação do governo um sinal de assalto das forças fascistas no Brasil, ainda que contra estas se devesse estar sempre vigilante. O deputado disse ainda que o PSB "se utiliza dos meios democráticos e legais para realizar o pensamento revolucionário", e que se tratava de um partido brasileiro - uma alusão ao fato de que o PCB era, por vezes, referido como "agência soviética". 330

De forma drástica, no ano de 1947, a relação entre socialismo e comunismo ganhou seus contornos finais no Brasil. Acossados pela forma como políticos e imprensa associavam o PSB ao PCB, os socialistas ofereceram apenas protestos pontuais contra a repressão do governo aos comunistas. Repressão que se estendeu ao movimento sindical, meio onde o PSB almejava ampliar sua ainda débil influência. Como no cenário internacional - excetuando-se a Itália -, a cisão entre as correntes de esquerda estava definitivamente completada, embora o linchamento de um Partido Comunista, como ocorrido com o brasileiro, certamente atentasse contra os

\footnotetext{
${ }^{329}$ Nunca pertenceram ao PCB. Diário de Notícias, 20.09.1947, p. 8.

330 Recebido com os mais vivos aplausos a nota do governo comunicando ao Parlamento o rompimento das relações diplomáticas entre o Brasil e a Rússia. Jornal do Brasil, 22.10.1947, p. 9.
} 
escrúpulos da opinião pública de qualquer país com regime democrático mais sólido no pósSegunda Guerra.

\subsection{Em nome do socialismo democrático}

"Cabe-nos a tarefa de inaugurar a era do socialismo democrático". Com essas palavras, Harold Laski dirigiu-se a 750 delegados representantes de mais de 6 milhões de operários britânicos reunidos no Congresso Sindical de Blackpool, em setembro de 1945, logo após o fim da guerra. ${ }^{331}$ Prenúncio de um novo tempo de paz e igualdade, assim se esperava, o binômio socialismo democrático tornou-se uma "ideia-força" aparentemente consistente no imediato pós-guerra.

O conceito ecoou no Brasil, e o PSB, pela vocação autoimposta e apesar de pequeno, tornou-se seu principal porta-voz na imprensa nacional. Pelos anos de 1947 e 1948, foram divulgados nos jornais convites para uma série de exposições orais proferidas por Hermes Lima com a finalidade de explicar as ideias fundamentais do socialismo democrático. Com o PCB fora da jogada, ao menos até onde os entraves oficiais conseguiam impor barreiras à atuação dos comunistas, os socialistas poderiam supor, com ou sem constrangimento, que o caminho estava agora mais livre para a disseminação das suas ideias.

Os fatos, porém, desenrolaram-se em outra direção. No final da década de 1940, foram os trabalhistas a principal força política emergente, angariando amplo apoio entre os trabalhadores, sobretudo após o retorno triunfal do ex-ditador. ${ }^{332}$ Antes da eleição de Vargas, porém, à semelhança do que ocorrera quando se insinuou na imprensa uma hipotética aliança eleitoral entre socialistas e comunistas, foi a vez de os jornais sugerirem que o PSB poderia se juntar ao PTB. Como vimos, ao longo da segunda metade da década de 1950 a aliança entre os dois partidos realmente se consumou, chegando-se mesmo a prever uma fusão partidária. Em 1947 tal fusão já era especulada na imprensa como algo capaz de unir um corpo a uma cabeça, ou seja, mesclar um partido com base popular com os respeitados quadros intelectuais socialistas. Lançada precocemente, a sugestão desagradava profundamente a estes últimos. Foi

\footnotetext{
${ }^{331}$ A era do capitalismo se aproxima do seu fim. Correio da Manhã, 11.09.1945, p. 1.

${ }^{332}$ Evidentemente, o PCB não saiu de cena a partir desse período. Como se sabe, trabalhistas e comunistas construíram uma trajetória de lutas sindicais unitárias ao longo do regime de 1945-1964. Ver SANTANA, Marco Aurélio. Bravos companheiros: a aliança comunista-trabalhista no sindicalismo brasileiro (1945-1964). In: FERREIRA, Jorge; REIS, Daniel Aarão (Orgs.). As esquerdas no Brasil: nacionalismo e reformismo radical. 1945-1964. Rio de Janeiro: Civilização Brasileira, 2007, v. 2.
} 
o escritor Rubem Braga, membro de primeira hora da Esquerda Democrática, quem se encarregou de responder aos rumores:

Se a Esquerda Democrática foi fundada é porque era preciso haver no Brasil um partido que representasse não somente em certas emergências, mas constantemente, certo tipo de pensamento político. Um partido que não tivesse como o Comunista, sua tática de luta dependente de uma estratégia extranacional, e onde a ideia socialista, associada à democracia, não fosse uma vaga 'parola' como frequentemente é na UDN. (...). Seu futuro depende exatamente da firmeza com que marcar sua posição e da clareza com que puder fazer o público senti-la. Um partido como esse não deve e não pode crescer a 'golpes'. Crescerá pela educação e esclarecimento do povo, mantendo suas ideias e uma exemplar dignidade de conduta. ${ }^{333}$

No final de 1947, uma reunião plenária da Comissão Nacional do PSB produziu definições mais claras a respeito do lugar pretendido pelo partido na política brasileira. Segundo relato da Comissão Estadual paulista, os resultados obtidos pela reunião criaram certo contentamento entre o conjunto da militância socialista. Apesar de Hermes Lima ter manifestado simpatia em relação ao acordo interpartidário, argumentando que este "poderia revestir-se da maior significação para o retorno do país ao regime da lei, de que estava fugindo em face da política reacionária do governo", as deliberações seguiram rumos distintos. Lideranças como Osório Borba e toda a Comissão Paulista foram contrários ao acordo interpartidário, partilhando a crença de que que aderir ao "acordão" significaria assumir a defesa de um governo cujas práticas eram completamente estranhas ao programa do partido. Como contraproposta para a intervenção socialista na política nacional, decidiu-se por um maior centralismo partidário a partir da criação de uma Comissão de Estudos Legislativos, composta “pelos representantes parlamentares do partido, por companheiros especializados em assuntos a serem focalizados e por simpatizantes nas mesmas condições, com o objetivo de facilitar as tarefas dos deputados e vereadores socialistas". 334

Outro momento do debate foi dedicado às deliberações acerca do projeto histórico de socialismo ao qual o PSB subscreveria. Alceu Marinho do Rego, integrante destacado da Comissão Nacional, entendia que o partido deveria assumir postura mais enérgica em relação ao comunismo, atacando-o de frente, pois, uma vez que o mundo se dividia entre democracia e comunismo, os socialistas enquanto democratas deveriam ser coerentes com essa realidade (deve-se lembrar que a expansão da influência soviética sobre o Leste europeu, então em curso,

\footnotetext{
${ }^{333}$ BRAGA, Rubem. Manobra. Folha da Noite, 25.04.1947, p. 2.

${ }^{334}$ MELLO, Plínio Gomes de. Orientação partidária em face da situação política do país. Folha Socialista, n. 3, 10.01 .1948 , p. 1-2.
} 
estimulava com frequência a oposição democracia versus totalitarismo). Plínio de Melo, o representante da Comissão Estadual de São Paulo, defendeu que os comunistas deveriam ser responsabilizados pelo mau uso das liberdades democráticas após a queda da ditadura, mas que em face da conjuntura internacional era necessário criar um terceiro campo que, diferentemente dos blocos imperialistas, lutasse pela paz, pelo socialismo e pela liberdade. Mais preocupados em não diluir o socialismo dentro de uma retórica democrática genérica, os paulistas propuseram resoluções orientadas a assegurar "maior independência do movimento socialista em relação ao comunismo e à reação, preservando o lugar da atuação do socialismo democrático no país". Segundo o grupo, "esse é o caminho do socialismo democrático, cujos frutos já começam a aparecer através das medidas adotadas pelo governo trabalhista na Inglaterra e por outros governos socialistas na Europa". ${ }^{335}$ Por fim, confirmando a preponderância teórica dos paulistas, duas resoluções aprovadas buscavam garantir

[...] a manutenção de linhas divisórias precisas entre o Partido Socialista Brasileiro e as demais organizações partidárias do país, [e] o reforçamento da repulsa a qualquer manifestação de origem reacionária e a qualquer atividade política de franca ou disfarçadamente totalitária, de modo que se assegure ao Socialismo Democrático a possibilidade do pleno desenvolvimento. ${ }^{336}$

Como se pudessem recuperar ou recriar o tempo perdido, como se pudessem prescindir de um passado glorioso, os representantes do socialismo democrático brasileiro pareciam encher-se de expectativas positivas quanto ao futuro de suas propostas. Do lado adversário, os socialistas viam enfileirar-se um rol de partidos concorrentes cuja principal característica era, além da debilidade ideológica, o reacionarismo entendido como sempre à espreita para deter a marcha do socialismo. Tudo em nome da perpetuação das contradições sociais a que esses partidos serviam, mas que para os socialistas estavam fadadas a sucumbir aos novos tempos. Nas palavras do militante socialista Isaac Izeckson:

Para sair da plutocracia tendente para o fascismo e incapaz de resolver as contradições que criou, sem cair no Capitalismo de Estado anulador do indivíduo livre, a humanidade tem à sua frente, indicada pelo desenvolvimento histórico, pela lógica dos fatos e pelos mais legítimos anseios de liberdade, de justiça, de paz e de esperanças no progresso moral e material, a larga e sorridente estrada do Socialismo Democrático, a verdadeira síntese de todos os movimentos de emancipação humana. ${ }^{337}$

\footnotetext{
335 Idem.

${ }^{336}$ Esteve reunida a Comissão Nacional do PSB, Diário de Notícias, 16.12.1947, p. 4.

${ }^{337}$ IZECKSON, Isaac. Democracia e socialismo, Diário de Notícias, 07.12.1947, p. 24.
} 
Enquanto na Inglaterra o Labour Party começava a encarar críticas mais duras de uma oposição já não tão tímida em relação às reformas do Welfare State, no Brasil os socialistas aumentavam na imprensa o tom de sua confiança na fórmula do socialismo democrático. Não havia pressa em vê-lo crescer. Afinal, tratava-se de uma tradição ainda a enraizar-se. Tampouco havia necessidade de comprometer-se em alianças passíveis de descaracterizá-lo. Contra si, na visão dos socialistas, persistiria o ambiente político contaminado por concepções estreitas, ou mesmo a má fé de quem os equiparava ao comunismo de tipo soviético, contra o qual o PSB também fazia coro:

[O PSB] é tão virulentamente combatido, insultado, caluniado pelos comunistas como pelos fascistas de todos os matizes. Por isso mesmo, seu crescimento é lento, porque corresponde a um movimento - o grande movimento universal do socialismo - que no Brasil, entretanto, não era uma tradição. E cresce lentamente porque age isolado, sem procurar alianças comprometedoras, e hostilizado tanto por reacionários quanto pelos comunistas e pelos demagogos do 'trabalhismo' de origem ditatorial. (...) O partido que no Brasil prega o socialismo tem a mesma ideologia, usa os mesmos métodos, dirige-se ao mesmo fim que todos os partidos socialistas dos países mais cultos, onde nem os últimos dos ignorantes os confundem com os Partidos Comunistas. ${ }^{338}$

É proveitosa, ainda, a citação de uma crítica ao encarecimento do custo de vida no Brasil durante o governo Dutra, feita pelo dramaturgo, escritor e socialista Raimundo Magalhães Junior, que se tornaria vereador pelo PSB do Distrito Federal nos anos 1950. Segundo Magalhães Junior, o custo de vida no Brasil estaria mais alto do que na Inglaterra por que este último país,

Sob a égide do socialismo democrático - o mesmo que propugnamos e queremos ver adotado no Brasil, porque concilia o máximo de liberdade com o máximo de justiça social - está nos apontando o grande caminho e nos dando lições admiráveis de compreensão da realidade contemporânea. Pode-se dizer que o capitalismo clássico morreu naquele país e que o povo hoje alcança as maiores conquistas, graças ao Partido Trabalhista (não confundir com o nosso trabalhismo-demagógico e antidemocrático) e a homens de Estado que não hesitaram em destruir a velha, a desmoralizada e anacrônica economia inglesa de antes da guerra, para erigir sobre os seus escombros um regime de igualdade como não existe em nenhum outro país do mundo. ${ }^{339}$

A destacada liderança do PSB paulista, Febus Gikovate acreditava que, em face da crescente divisão do mundo em duas esferas de influência, tornava-se forçoso construir um terceiro campo em âmbito mundial, a "frente socialista democrática". O momento seria

\footnotetext{
${ }^{338}$ BORBA, Osorio. A eterna chantagem fascista, Diário de Notícias, 21.08.1949, p. 4.

${ }^{339}$ MAGALHÃES JUNIOR, Raimundo. A ilusão dos aumentos, Diário de Notícias, 03.12.1948, p. 9.
} 
oportuno, pois segundo Gikovate nenhum dos polos hegemônicos estava disposto a ir às vias de fato de um conflito aberto e tampouco imprimir uma política agressiva contra as alternativas políticas fora de suas esferas de influência. Para Gikovate, a área socialista democrática já existia, mas ainda não havia tomado corpo enquanto "frente", porquanto os setores que a compunham gravitavam eventualmente entre os campos soviético ou norte-americano. Gikovate lamentava que nas conferências que reuniram os partidos socialistas europeus até aquele momento ainda não se tivesse tomado a decisão de reconstruir a Internacional Socialista, devido ao temor de que se provocasse uma ruptura com os partidos socialistas da Europa Oriental, "parcial ou totalmente stalinizados". 340

Em uma longa série de artigos escritos para o jornal Diário de Notícias intitulada "Bases para a defesa da democracia”, Domingos Vellasco buscou explicitar os desentendidos acerca do lugar reivindicado pelo o PSB: "Para os reacionários comunistas, a organização de uma Terceira Força é comodismo, deserção da luta, ajuda à reação fascista, a soldo do capitalismo, etc. Para os reacionários capitalistas, é 'criptocomunismo', 'linha auxiliar', ouro de Moscou, etc." 341 Sem deixar de proclamar seu "cristianismo social", característica dos discursos do deputado, Vellasco insistia que tanto os cristãos quanto os socialistas deveriam julgar injustificáveis os monopólios das empresas prestadoras de serviços, e que, portanto, deveriam também se bater pela "ascensão das massas e pela transformação das estruturas". Lembrou por fim que "apesar de nitidamente socialista, o Labour Party abrigava, em suas fileiras, marxistas, cristãos de várias seitas protestantes e católicos apostólicos romanos e, pela palavra de Harold Laski, proclamava o socialismo democrático" ${ }^{342}$. Desta forma, ao contestar determinadas inclinações ao conservadorismo por parte dos cristãos, Vellasco prosseguia nas suas tentativas de angariar adeptos para o PSB entre estes setores, mas dessa vez utilizando a fórmula "socialismo democrático" para diluir eventuais diferenças de concepções em torno da política e da religião.

Em janeiro de 1948, Febus Gikovate propagandeava na Folha Socialista o que seria a eficiência econômica alcançada pelo governo trabalhista na Inglaterra, onde, segundo dizia o socialista, a crise inicial do pós-guerra vinha sendo superada com recordes na produção de carvão, "graças à consciência socialista dos mineiros". E prosseguia argumentando que, por

\footnotetext{
${ }^{340}$ GIKOVATE, Febus. Resenha internacional. Folha Socialista, n. 1, 27.11.1947, p. 3.

${ }^{341}$ VELLASCO, Domingos. União para a defesa da democracia. Diário de Notícias, 15.02.1948. p. 7.

${ }^{342}$ Idem, p. 7.
} 
mais que diversas greves tivessem sido realizadas naquele país, o governo trabalhista não teria enveredado pelo caminho da coerção e nem lhes teria subtraído os direitos. ${ }^{343}$ Gikovate parece, assim, pintar um quadro idílico à semelhança da propaganda soviética transmitida pelos PC aos quatro cantos do mundo. Bem diferente era o quadro de preocupação com os "congêneres britânicos" apresentado no mês seguinte nas páginas do Vanguarda Socialista. Nele se dizia que o governo trabalhista já começava a sofrer represálias dos plutocratas e oligopólios, recebendo o troco por ter acreditado ser possível realizar reformas em clima de harmonia e com um Parlamento incapaz de criar entraves às nacionalizações. Como remédio para que a situação não se tornasse incontrolável, o Vanguarda preconizava a mobilização e a participação direta e independente dos trabalhadores na transformação do regime de propriedade. $\mathrm{O}$ controle operário sobre a produção, diz o jornal, seria da maior urgência, tanto nas indústrias nacionalizadas quanto nas que ainda eram privadas. Ao caráter nacionalizador do governo faltaria o caráter democrático e popular. ${ }^{344}$

Como vimos, a questão sobre as relações entre e Estado, nacionalização e socialização já havia aparecido no debate entre os socialistas durante a Constituinte de 1946 (ver Capítulo III, Item 3.5.3). No final dos anos 1940, novos elementos conjunturais se somaram a essas discussões, como, por exemplo, a campanha pelo monopólio estatal do petróleo, que passaremos a analisar a seguir. Mais adiante, analisaremos como os socialistas buscaram propor e encaminhar mudanças na estrutura sindical brasileira e sua relação com o Estado. Por fim, examinaremos como os caminhos tomados pelo movimento socialista internacional refletiram na ideologia socialista democrática, propugnada pelo PSB.

\subsection{O monopólio estatal da exploração do petróleo com objetivos socialistas}

A campanha em defesa do monopólio estatal na exploração do petróleo ganhou força ao longo do ano de 1948, na medida em que entidades e lideranças militares e civis aderiam ao movimento iniciado após o presidente Dutra designar uma comissão para rever as leis existentes à luz da nova Constituição e definir as diretrizes para a exploração do petróleo. O trabalho da comissão resultou no envio ao Congresso do anteprojeto do Estatuto do Petróleo, contendo

\footnotetext{
${ }^{343}$ GIKOVATE, Febus. Resenha internacional. Folha Socialista, n. 3, 10.01.1948, p. 4.

${ }^{344}$ A primeira crise do Trabalhismo Inglês. Vanguarda Socialista, n. 77, 14.02.1948, p. 4 e 2.
} 
pontos que desagradaram tanto os setores favoráveis à ampla participação do capital estrangeiro no setor quanto os setores favoráveis a políticas estatistas e nacionalistas. ${ }^{345}$

Em princípios de março a campanha em defesa do monopólio estatal do petróleo já conseguia mobilizar a opinião de estudantes, da imprensa e de diversas categorias de trabalhadores. Na sede da UNE, no Rio de Janeiro, foi instituída a Comissão Estudantil de Defesa do Petróleo, sob a liderança do presidente da entidade, Roberto Gusmão, membro do PSB. Em São Paulo, o também socialista Rogê Ferreira - que, no ano seguinte, sucederia a Gusmão na presidência da UNE - liderou representantes estudantis de diversas Faculdades que lançaram um manifesto uníssono com a inciativa da UNE. ${ }^{346} \mathrm{O}$ manifesto expressava as linhas gerais da campanha em gestação:

O Estatuto do Petróleo, lei antinacional e de lesa-pátria, tenta conciliar interesses irreconciliáveis, instituindo companhias mistas, na qual o truste, através de suas ações, controla dominadoramente a extração do petróleo. ${ }^{347}$

No mês seguinte, foi a vez de jornalistas lançarem seu manifesto "contra a entrega direta ou indireta, total ou parcial, do petróleo brasileiro". O documento contou com as assinaturas dos socialistas Osório Borba - na época, vereador do Distrito Federal - e Rubem Braga. ${ }^{348}$ Em seguida, no dia 14 de abril de 1948, fundou-se o Centro de Estudos e Defesa do Petróleo (CEDP) - mais tarde rebatizado de Centro de Estudos e Defesa do Petróleo e da Economia Nacional com a reunião de militares, políticos, intelectuais, estudantes, dentre outros. Entre os seletos membros da comissão diretora da entidade estavam Osório Borba e Roberto Gusmão - o último representando os estudantes -, além da presença do também socialista Bayard Demaria Boyteux, encarregado da tesouraria. ${ }^{349}$

No final de setembro, após um congresso realizado no Rio de Janeiro, o CEDP definiria melhor seus objetivos. Além da meta central de derrotar o anteprojeto "entreguista" do Estatuto do Petróleo, ficou decidido que a entidade atuaria contra qualquer tipo de participação de

\footnotetext{
345 DIAS, José Luciano de Mattos; QUAGLINO, Maria Ana. A questão do petróleo no Brasil: uma história da Petrobras. Rio de Janeiro: CPDOC: Serinst: FGV: Petrobrás, 1993, p. 95.

${ }^{346}$ Cf. VICTOR, Mário. A batalha do petróleo brasileiro. Rio de Janeiro: Civilização Brasileira, 1970, p. $226-227$.

${ }^{347}$ Ibidem, p. 227.

${ }^{348}$ Cf. Ibidem, p. 229-230.

${ }^{349}$ Cf. Ibidem, p. 231-232. O autor fala ainda da criação de alguns centros estaduais com os mesmos objetivos do CEDP, dentre eles o de Sergipe, sob a liderança do socialista Orlando Dantas, que teria atuação destacada na Câmara Federal (1950-1954) em defesa do monopólio estatal do petróleo e da criação da Petrobrás. Ibidem, p. 236.
} 
estrangeiros na exploração, pesquisa, refino, transporte e distribuição do petróleo. A possibilidade de tomar empréstimos externos poderia ser avaliada, desde que não resultasse em outra coisa senão o simples pagamento de juros e amortizações. ${ }^{350}$

No Congresso Nacional, Hermes Lima foi o responsável por inaugurar o debate acerca do Estatuto do Petróleo, pronunciando seu discurso cercado de uma audiência atenta dos colegas e da imprensa. Segundo o deputado, o Estatuto do Petróleo - devidamente reelaborado - complementaria a obra da Constituição de 1946, ao garantir ao regime recém-estabelecido os meios de assegurar a "alforria econômica" e de subjugar o poderio econômico estranho aos princípios constitucionais. Referindo-se aos sistemas elaborados para a exploração do petróleo na Venezuela, na Colômbia e no Peru, Hermes Lima argumentou que não fizeram mais que transferir aos trustes uma posição de domínio econômico que só deveria caber ao Estado - o deputado citou ainda o México, onde o governo do presidente Cárdenas (1934-1940) resolvera pela expropriação das companhias petrolíferas estrangeiras. Em seguida, o deputado disse ser um consenso que os interesses em torno do petróleo não diziam mais respeito à disputa livre por mercados, como no início do século XX; no centro capitalista, mediante controles estatais, qualquer companhia de petróleo já teria então se tornado uma agência estratégica para operações de expansão militar e econômica dos governos. Hermes Lima indagou os colegas por que deveria se esperar que no Brasil as concessões produzissem resultados especiais e diferentes em relação aos seus vizinhos latino-americanos. ${ }^{351}$

Contudo, como notado pelo próprio Hermes Lima, o relatório oficial assinado por Odilon Braga (UDN), e enviado ao Congresso juntamente ao anteprojeto do Estatuto do Petróleo, já havia buscado responder às indagações do deputado socialista, com os argumentos de que o New Deal havia modificado a linha geral de conduta das empresas, e que como o assunto do petróleo passou à orbita dos Estados, haveria plena possibilidade da colaboração internacional evitar potenciais abusos advindos dos interesses privados. Esses argumentos foram logo rebatidos por Hermes Lima, que novamente remeteu-se aos casos latino-americanos para concluir que em nenhum lugar do continente observou-se qualquer diminuição dos abusos

\footnotetext{
${ }^{350}$ Só o Estado deve explorar o petróleo. Diário de Notícias, 01.10.1948, p. 9.

${ }^{351}$ O problema da exploração do nosso petróleo. Correio da Manhã, 20.03.1948, p. 3 e 12.
} 
dos trustes, e que não se poderia esperar garantias de que as empresas estrangeiras se submeteriam ao alegado "controle ético e político de um outro New Deal pan-americano". 352

Rebatendo a alegação contida no relatório de Odilon Braga de que os governos brasileiros careceriam de recursos para encontrar e explorar reservas de petróleo, Hermes Lima insistiu que o problema poderia ser superado com simples impostos - por exemplo do fumo e da bebida - e com transferências de recursos de outros projetos com "proveitos remotos" como o Plano de Valorização Econômica da Amazônia -, tendo em vista o impulso dinâmico que a exploração do petróleo poderia trazer em benefício de toda a economia nacional. $\mathrm{O}$ deputado acrescentou, ainda, que os próprios trustes não investiriam tanto logo de início, e que o custeio por parte do Estado, caso este monopolizasse a exploração do petróleo, ocorreria de forma gradual e equilibrada. Hermes Lima buscou demonstrar que havia limites intransponíveis à ação fiscalizadora do Estado sobre a atuação dos trustes, contrariando a premissa fundamental sustentada pelo anteprojeto do Estatuto do Petróleo. Para o deputado socialista, em países economicamente débeis, a fiscalização estatal jamais conseguiria fazer frente ao poder dos trustes petrolíferos, pois, após estes terem invadido a estrutura econômica do país fraco, criarse-ia uma situação de luta entre três partes antagônicas: o poder político desarmado economicamente; o poder político dependente dos trustes; e os trustes, municiados pelos Estados fortes a cuja política eles servem. ${ }^{353}$

Estas últimas conclusões do discurso de Hermes Lima estavam no cerne das preocupações da Comissão Estadual do PSB de São Paulo, que esteve reunida em meados de abril de 1948, em Bauru, para discutir uma série de assuntos, dentre eles o do petróleo. As resoluções do encontro foram incorporadas ao programa do partido, e reproduzidas em um folheto intitulado Posições Socialistas. Nesse documento, Febus Gikovate expôs preocupações em torno da campanha pelo monopólio estatal do petróleo, advertindo para os riscos de o movimento ser contaminado por uma demagogia "nacionalista-chauvinista", favorável aos interesses da elite econômica nacional e contrária ao princípio da socialização dos meios de produção. Dessa forma, o PSB deveria buscar diferenciar claramente os distintos objetivos no interior da campanha, para que as demandas populares não fossem diluídas, segundo Gikovate,

\footnotetext{
352 Idem. A citação foi retirada do próprio relatório apresentado por Odilon Braga, que presidiu a comissão designada pelo presidente Dutra para elaborar o anteprojeto do Estatuto do petróleo.

${ }^{353}$ A solução proposta pelo governo para o problema do petróleo. Correio da Manhã, 23.03.1948, p. 14. O longo discurso de Hermes Lima estendeu-se por duas sessões plenárias da Câmara dos Deputados.
} 
na barganha da burguesia brasileira que estaria buscando somente melhores condições de sobrevivência e adaptação aos interesses imperialistas. ${ }^{354}$

O documento assinado por Gikovate afirma que o PSB não confiava somente à "solução adequada do problema do petróleo" o caminho da superação da situação "calamitosa" da economia nacional. A solução definitiva, prosseguia o documento, começaria a se delinear no processo de transformação político-econômica no sentido socialista; para tanto, a reforma agrária seria uma condição tão ou mais importante do que a estatização da futura indústria petrolífera. Afirmava-se ainda que, para o PSB, a problemática em torno da exploração do petróleo não dizia respeito simplesmente às perspectivas da participação de trustes estrangeiros, pois se fosse um truste nacional, o partido se colocaria igualmente contrário à entrega das jazidas. Por fim, é apontado o diferencial com o qual os socialistas deveriam prosseguir na campanha pelo petróleo:

[O] PSB quer que este monopólio do Estado, ou seja, a nacionalização da indústria petrolífera, se realize segundo as afirmações de nosso programa, isto é, que seja assegurada a participação dos trabalhadores na direção das empresas a serem criadas [...] para evitar que as mesmas sejam exploradas em benefício exclusivo das atuais classes dominantes e se transformem em elemento para um futuro capitalismo de Estado, econômica e politicamente totalitário. ${ }^{355}$

É difícil ter uma dimensão precisa do quanto a orientação da linha política do PSB referente ao petróleo conseguiu alterar o sentido e o curso da intervenção do partido na campanha promovida por diversos setores da sociedade. Pouco antes dos esforços da comissão paulista para promover a inflexão apresentada acima, uma reunião da Comissão Nacional do PSB, em fins de março, refletiu a postura das principais lideranças partidárias até aquele momento:

Resolveu a Comissão que o Partido, pela sua bancada na Câmara Federal, combata intransigentemente o projeto, defendendo a solução do monopólio estatal. Deliberou ainda recomendar a todas as secções estaduais e a todos os representantes socialistas nas Câmaras estaduais e municipais de todo país que agitem por todos os meios possíveis o problema, dando assim a máxima colaboração à campanha nacional contra qualquer forma de entrega de concessões aos monopólios internacionais do petróleo. ${ }^{356}$

\footnotetext{
${ }^{354}$ GIKOVATE, Febus. A campanha em prol do petróleo nacional. In: PSB. Posições Socialistas. São Paulo: Edições do PSB (Seção Paulista), 1949, p. 71-72.

${ }^{355}$ Idem.

${ }^{356}$ Petróleo, Reforma Agrária, Lei Sindical. Folha Socialista, n. 7, 12.05.1948, p. 1.
} 
A campanha do petróleo prosseguiu, e nas fases posteriores vivenciadas pela militância do PSB, observou-se, sobretudo nos anos 1950, uma maior inclinação do partido a concentrar esforços em um projeto comum nacionalista e reformista (ver Capítulo II, item 2.4), projeto este que surgiu como desdobramento da atuação de diversos setores políticos e que os socialistas não poderiam ter previsto ao final da década de 1940. Contudo, a dimensão socializante do programa do PSB pareceu ter perdido espaço por algum tempo.

\section{6 "Política sindical socialista" e o Projeto Mangabeira}

Pouco tempo depois do governo Dutra publicar uma portaria do Ministério do Trabalho, impondo severos controles ao exercício das eleições nos sindicatos, um artigo da Folha Socialista, assinado por Oliveiros S. Ferreira, fez um chamado "por uma política sindical socialista", com base na luta pela autonomia dos sindicatos. O chamado partia do entendimento de que o governo continuava operando conforme a mesma lógica reacionária e fascista com que se elaborou a Consolidação das Leis Trabalhistas, com a diferença de que, após a perda de certas prerrogativas ditatoriais, a principal preocupação do Ministério do Trabalho era impedir que os sindicatos saíssem do controle dos "amarelos" - lideranças sindicais ministerialistas - e caíssem sob a direção dos comunistas ou de elementos mais à esquerda do trabalhismo. Tratavase, na concepção dos socialistas, de vencer as amarras que impediam a autonomia sindical e que eram mantidas, principalmente, graças ao imposto sindical, fundamental para a atuação dos burocratas em conjunto com a Comissão do Imposto Sindical, que a pretexto de fiscalizarem a justa aplicação dos fundos arrecadados, interviam na vida dos órgãos da classe operária. ${ }^{357}$

A partir de uma releitura sobre o movimento operário brasileiro, Oliveiros Ferreira sustentou ter existido até então duas tradições de sindicalismo no país: a anarcossindicalista e a anti-autonomista. Esta última, então vigente, seria a hegemônica, compreendendo não só os elementos ministerialistas como também os comunistas. Para que se constituísse uma nova tradição - a socialista - disposta a desatrelar os sindicatos dos interesses partidários de "amarelos" e comunistas, o documento ponderava que não era possível desassociar as lutas por reivindicações econômicas da luta política. Em decorrência, as lutas econômicas deveriam se orientar no sentido de tornar os sindicatos "verdadeiras escolas de educação proletária e socialista", pois, uma vez que avançasse a luta por autonomia, com os trabalhadores

\footnotetext{
${ }^{357}$ FERREIRA, Oliveiros S. Liberdade e autonomia para os sindicatos. Por uma política sindical socialista. Folha Socialista, n. 4, 07.02.1948, p. 1-3.
} 
pressionando as diretorias através das assembleias, avançaria junto a consciência do trabalhador e de sua força organizativa. Como resultado esperado pelos socialistas, o governo não encontraria mais as mesmas bases que lhe garantiam a intervenção nos órgãos da classe operária. Contudo, o artigo fazia um alerta para a atividade do clero, que por meio da Juventude Operária Católica tentaria "transformar seus círculos operários em órgãos de classe, servindo ao manejo do clero e da burguesia". 358

O texto de Oliveiros Ferreira ainda ressalta que, ao experimentarem os efeitos e as responsabilidades da autonomia, os trabalhadores não se deixariam ludibriar com projetos de lei como os que pretendiam regular sua participação nos lucros das empresas. Os socialistas de São Paulo entendiam que a regulamentação do direito poderia ser uma "faca de dois gumes":

Se por um lado proporciona aos trabalhadores a possibilidade de se familiarizarem com as questões técnicas da produção, através dos comitês de controle da direção, permitindo-lhes assim a futura direção da economia socialista, por outro lado, como tem sido colocada até agora no Parlamento, levará a uma divisão do movimento operário, a uma diferenciação em camadas estruturadas na base de salário, etc. Mas, sobretudo, esta participação será um engodo porque a autonomia sindical, sem a qual os sindicatos não poderão cumprir sua missão, é completamente ignorada pelos deputados que apresentaram tais projetos. ${ }^{359}$

Por essa perspectiva, como já nos referimos anteriormente (ver Capítulo III, item 3.5.1), a solução adequada para a questão da participação dos trabalhadores nos lucros das empresas dependia de fatores mais amplos que previam antecipar elementos de uma futura sociedade socialista. A luta por autonomia sindical, dessa forma, seria o componente fundamental para a "educação socialista" de uma classe operária condicionada historicamente à tutela estatalconservadora. Tal concepção, contudo, não retirava ou minimizava a importância da atuação harmônica dos socialistas no parlamento, mesmo que sua representação numérica fosse ainda pequena no legislativo federal:

Esta tarefa deverá ser iniciada no Parlamento, através da apresentação de projetos reformando estruturalmente a Consolidação das Leis do Trabalho, com a abolição do imposto sindical e, no sentido de um despertar de consciência socialista e melhoria das condições de vida da classe operária, da batalha em torno da regulamentação da participação nos lucros das empresas

\footnotetext{
${ }^{358}$ Idem.

${ }^{359}$ Idem.
} 
nas únicas bases em que poderá ser efetivada sem prejuízo da classe operária. $^{360}$

As esperanças do PSB de São Paulo de ver um projeto socialista tramitar no Congresso não estavam desconectadas dos rumos da política brasileira e nem dos planos do próprio partido com relação a sua intervenção nacional. A intransigente política do governo Dutra de manter centenas de sindicatos sob intervenção provocava os opositores a oferecer respostas ou exigir reformas. Tanto era assim, que João Mangabeira, presidente do PSB, tomou a iniciativa de elaborar e apresentar à Câmara dos Deputados um anteprojeto de reforma da Lei Sindical.

Em entrevista para um jornal do Rio de Janeiro, reproduzida nas páginas da Folha Socialista, Mangabeira explicou que seu projeto visava livrar os sindicatos da intervenção tanto do governo quanto dos partidos, para que pudessem ser, de fato, órgãos representativos das categorias profissionais. O projeto concebia que as eleições sindicais fossem realizadas por voto secreto, no local de trabalho, e organizadas por Tribunais Sindicais compostos por "pessoas idôneas, uma das quais nomeada pelo presidente da República e as outras designadas pelas Federações Sindicais". Os Tribunais Sindicais seriam independentes do Ministério do Trabalho, atuando como fiscais da lei sindical e da aplicação legal das rendas sindicais. Além de eleger a diretoria representante de sua categoria, os trabalhadores elegeriam também um delegado por empresa que, junto com os delegados nomeados pela direção da empresa, formariam a Comissão Conjunta, responsável por buscar "conciliar os interesses entre empregados e empregadores, de modo que a empresa funcione como uma comunidade produtiva". ${ }^{361}$

Ao defender a manutenção do imposto sindical, João Mangabeira afirmou que o problema em torno da questão se resumia à má aplicação dos fundos arrecadados, o que seria corrigido, segundo o deputado, com a criação dos Tribunais Sindicais mencionados anteriormente. Para Mangabeira, os protestos contra o pagamento da "contribuição sindical" termo que o socialista preferia empregar - não expressavam mais que um sentimento de revolta "contra a dissipação de dinheiros penosamente ganhos e loucamente esbanjados". 362 Por fim, declarando-se a favor da unidade sindical, João Mangabeira incluiu um dispositivo em seu projeto que, caso aprovado, tornaria difícil a pluralidade, ao estabelecer que um sindicato só

\footnotetext{
360 Idem. Após as eleições complementares de 1947 e as defecções na bancada socialista, eram três os representantes do PSB na Câmara Federal: João Mangabeira, Hermes Lima e Domingos Vellasco. O partido não tinha senadores.

${ }^{361}$ Livrar os sindicatos da intervenção dos governos e dos partidos. Folha Socialista, n. 6, 10.04.1948, p. 5.

${ }^{362}$ Lei Sindical. Correio da Manhã, 10.04.1948, p. 12.
} 
poderia ser constituído se reunisse pelo menos um quarto dos trabalhadores de uma categoria. Porém, o deputado disse ao seu entrevistador que seu partido estava com a razão quando afirmava em seus documentos que a unidade sindical era uma aspiração que deveria ser realizada pelos próprios trabalhadores. ${ }^{363}$

O anteprojeto apresentado por João Mangabeira à Câmara dos Deputados causou divisão entre os socialistas. E não somente devido ao conteúdo das propostas, mas também pelo fato de o assunto não ter sido submetido ao escrutínio interno do partido. Os socialistas de São Paulo não demoraram a registrar seu protesto na imprensa partidária e a examinar o "Projeto Mangabeira". No calor das circunstâncias, a crítica ficou a cargo de Arnaldo Pedrosa D’Horta, não expressando uma posição oficial da Comissão Estadual do partido, pois essa ainda não havia se reunido para discutir o tema. Esperava-se, contudo, que o momento fosse oportuno para o esclarecimento das posições do PSB no que se referia à legislação trabalhista e aos sindicatos, e que no futuro discussões preliminares nos organismos partidários constituíssem objeto do trabalho dos parlamentares socialistas. ${ }^{364}$

De início, o artigo de Pedroso D'Horta pretendeu debater os fundamentos de uma estratégia socialista em face do regime democrático liberal, em uma resposta à declaração de João Mangabeira que justificou que seu projeto não era socialista porque o parlamento não o era tampouco. No entendimento do militante de São Paulo, todavia, apenas em uma sociedade socialista haveria uma legislação socialista, enquanto que na capitalista os socialistas buscariam introduzir elementos progressistas na legislação burguesa, abrindo caminho ao socialismo. De outro modo, prosseguia Pedroso D’Horta, não faria sentido a presença de socialistas no Parlamento. Por essa perspectiva, o "Projeto Mangabeira" foi visto como contraditório por pretender dar forma legal a determinadas posições socialistas e, em outros aspectos, parecer ter sido influenciado "pelas disposições e pressupostos da legislação pré-existente". ${ }^{365}$

A manutenção do imposto sindical era, na visão de Pedroso D’Horta, o mais sério defeito do anteprojeto, que impediria a superação do corporativismo e negava a própria ideia de um sindicalismo livre.

O imposto sindical é irmão gêmeo do sindicalismo corporativista. A quem pagarão os empregados esse imposto, se a organização sindical é livre? A que

\footnotetext{
${ }^{363}$ Livrar os sindicatos da intervenção dos governos e dos partidos. Op cit., p. 5.

364 D'HORTA, Arnaldo Pedroso. Coisas boas e más do anteprojeto da Lei Sindical. Folha Socialista, n. 6 , 10.04.1948, p. 5-6. 
sindicato será recolhido o imposto de um empregado não sindicalizado, pertencente a uma profissão na qual existem 2 ou 3 sindicatos concorrentes? E como sustentar o princípio da liberdade de organização sindical, e ao mesmo tempo da obrigatoriedade do imposto sindical?

Os esperados benefícios do imposto sindical foram muito mais reduzidos que os seus efetivos malefícios. Temos, hoje, sem dúvida, sindicatos ricos enquanto os de ontem, que apenas viviam das contribuições dos associados eram pobres. Porém, os sindicatos ricos de hoje deixaram de ser sindicatos, são repartições arrecadadoras o imposto sindical. Acresce a isso que, por permitir aos sindicatos a cobrança de um imposto, o Estado quer, logo em seguida, controlar a aplicação da renda obtida - e isso, que foi uma das principais características do sindicalismo sob o Estado Novo, subsiste no anteprojeto. ${ }^{366}$

Ainda que trivial, tratava-se, pois, de uma crítica mais profunda ao papel do imposto sindical do que previra o simples juízo de João Mangabeira em relação à natureza dos protestos dirigidos contra a manutenção daquele mecanismo. Ao mesmo tempo, tem-se no debate apresentado um exemplo do descompasso entre os organismos partidários do PSB.

Mais adiante, Pedroso D'Horta criticou a proposta de limitar os sindicatos por categoria profissional, o que impedia a formação de sindicatos por pessoas de diferentes profissões, representando, por exemplo, os trabalhadores de uma mesma empresa ou de pequenas cidades. Em troca, o autor sugeria que a lei facultasse todos os tipos de sindicatos, entendendo que o que daria sentido aos órgãos da classe trabalhadora seriam suas próprias demandas coletivas. Em seguida, reconhecendo no anteprojeto o aspecto positivo da suspensão do "atestado ideológico", Pedroso D'Horta questionou o princípio de proibir a utilização dos sindicatos por partidos políticos, pois ainda que este fosse um objetivo desejável, não poderia ser alcançado por força da lei. O raciocínio apresentado era lógico: se o anteprojeto mantinha prerrogativas oficiais para o arbítrio sobre a atividade sindical - através da criação dos Tribunais Sindicais, incluindo nomeação pelo próprio executivo federal - os sindicatos estariam colocados sob às ordens do partido dominante da nação. Assim, entendia-se que as manobras dos partidos políticos nos sindicatos seriam evitadas pelo próprio equilíbrio entre as distintas correntes do movimento sindical, servindo as assembleias dos sindicatos para o confronto político franco entre essas correntes. $^{367}$

Os objetivos propugnados por Pedroso D'Horta somente fariam sentido com uma legislação que inviabilizasse a intervenção do Estado na esfera sindical, minando, dessa

\footnotetext{
366 Idem.

${ }^{367}$ Idem.
} 
maneira, o campo de atuação dos elementos sindicais ministerialistas. Por conta disso, o "Projeto Mangabeira" também foi criticado pela forma extremamente minuciosa com que pretendia normatizar o funcionamento dos sindicatos, fixando, por exemplo, um número rígido de membros do conselho fiscal. $O$ artigo sustenta que a legislação deveria se restringir a enunciar os princípios norteadores dos estatutos e regimentos internos de cada sindicato. Em comum com esse entendimento, outros pontos do anteprojeto foram problematizados, como a criação dos "Tribunais Sindicais" e da "Comissão do Fundo Sindical - em substituição à “Comissão do Imposto Sindical” e independente em relação ao Ministério do Trabalho.

Teremos (...) uma nova e dispendiosa burocracia a pesar sobre os débeis organismos sindicais, a sugar-lhes quase todo o seu rendimento e a tuteá-los como a menores e incapazes.

Os direitos sindicais a serem preservados são direitos civis e políticos comuns - e não se vê bem o motivo da criação, em todo território nacional, de uma tão complicada e pesada maquinaria. Se o que se quer é dar maior rapidez ao julgamento das questões sindicais, e tornar os juízes mais familiares com os problemas que deverão decidir - bastaria a criação de varas especializadas na própria justiça comum. ${ }^{368}$

Apesar das críticas de Arnaldo Pedrosa D’Horta - as quais eram provavelmente endossadas por boa parte do PSB de São Paulo - apontando o que poderiam ser considerados vícios estadonovistas no "Projeto Mangabeira", este acabou suscitando a resistência dos elementos ministerialistas que o PSB, em conjunto, queria ver extintos. Entre os meses de março e abril de 1948, a Confederação Nacional dos Trabalhadores realizou uma série de reuniões com o objetivo expresso de debater o projeto de lei, buscando encaminhar uma pretensa posição dos trabalhadores acerca das propostas apresentadas. Nesse período, o presidente da entidade, João Batista de Almeida, disse estar preocupado em unir os trabalhadores contra o comunismo, enquanto outros dirigentes sindicais da mesma orientação política declararam que o projeto de João Mangabeira não atendia totalmente aos interesses dos trabalhadores brasileiros. ${ }^{369}$ O próprio ministro do Trabalho, Morvan Dias de Figueiredo, chegou a presidir uma reunião patrocinada por diversas direções sindicais ministerialistas com o propósito de obstruir as reformas. Ao final dessa reunião, os debatedores digiram-se ao Palácio do Catete para entregar ao presidente da República emendas ao "Projeto Mangabeira", além de uma versão própria de anteprojeto de reforma da legislação sindical. Já na sede da

\footnotetext{
368 Idem.

${ }^{369}$ Debates sobre o projeto de sindicalização. Correio da Manhã, 14.03.1948, p. 3.
} 
Presidência da República, uma das lideranças "amarelas", com o respaldo da estrutura legal corporativista, declarou:

Aqui se encontram nesse momento, 32 Federações e 2 Confederações, legalmente reconhecidas, congregando cerca de 500 sindicatos e, estes por sua vez, mais de um milhão de trabalhadores, e que se reuniram em pequeno congresso, nesta capital, para estudar o projeto de reforma da lei de sindicalização, de autoria do ilustre deputado João Mangabeira.

Estas federações e confederações, depois de estudarem o referido projeto, chegaram à conclusão de que não podiam aceitá-lo, tendo em vista, principalmente, que o mesmo vem alterar profundamente a sistemática sindical e a estruturação das instituições trabalhistas. Em síntese, é o mesmo incompatível com o nosso sistema e com a realidade sindical brasileira. ${ }^{370}$

Estas conclusões - a rigor, uma quase indisfarçável confissão de culpa - eram mesmo os objetivos manifestos por João Mangabeira quando da apresentação de seu projeto. Diante da resposta articulada pelos ministerialistas, as diferenças internas do PSB parecem ter arrefecido. Os paulistas, que em sua Folha Socialista buscaram acertar contas com o presidente do partido, passaram a primeiro plano a denúncia contra a reação ao projeto pela burocracia sindical em conluio com o Ministério do Trabalho. Tratava-se, antes, de cerrar fileiras para defender o "Projeto Mangabeira”, como sustentou Oliveiros Ferreira:

Há, assim, uma urgente necessidade da mobilização dos setores conscientes da classe operária na defesa do projeto Mangabeira. Esse pode ter os defeitos que tiver, mas é ainda a única saída para o impasse em que se encontra a vida sindical brasileira. Defendê-lo, é o dever de todos os socialistas e dos partidários da plena autonomia sindical. ${ }^{371}$

Um dos setores que se levantaram em defesa do "Projeto Mangabeira" foi a Juventude Operária Católica, a mesma organização que tinha sido posta em alerta pelo autor da passagem acima e do chamado "por uma política sindical socialista", referido anteriormente. E não foi uma defesa tímida das reformas, como demonstra o compromisso firmado pelo líder sindical católico, Francisco Tussini:

Atualmente, $[\ldots]$ os sindicatos são meros instrumentos do grupo ministerialista que procura por todos os meios impedir a reforma dessa lei fascista que é a 'Consolidação das Leis do Trabalho', cópia da famigerada "Carta del Lavoro", feita em épocas idas, para país fascista e para época fascista.

\footnotetext{
${ }^{370}$ Querem bombardear o projeto João Mangabeira. Correio da Manhã, 14.04.1948, p. 9.

${ }^{371}$ FERREIRA, Oliveiros S. O projeto Mangabeira sob os primeiros ataques. Folha Socialista, n. 6, 10.04.1948, p. 5.
} 
É necessário que se organizem, nas fábricas e em outros locais de trabalho, comissões de apoio ao projeto, e que essa luta se intensifique de dia para dia. ${ }^{372}$

Nessas circunstâncias, o PSB de São Paulo decidiu marcar seu posicionamento, estabelecendo, doravante, a defesa pública do projeto de João Mangabeira na sua integridade. Ao mesmo tempo, os paulistas se reservaram o direito de assumir uma posição ponderada, apresentando críticas com o mesmo teor das apresentadas anteriormente por Arnaldo Pedrosa D'Horta, quadro eminente entre os socialistas de São Paulo. ${ }^{373} \mathrm{Com}$ isso, como o debate mais geral acerca da política sindical a ser defendida pelo PSB permanecia em aberto, a questão foi rediscutida na II Convenção Estadual do PSB de São Paulo, realizada nos dias 4 e 5 de setembro, em Campinas. O próprio João Mangabeira se fez presente, e em um embate direto entre as suas posições e as críticas apresentadas pelo PSB paulista, dessa vez, representado por Febus Gikovate, o impasse se manteve. Como forma de contorná-lo, uma solução de compromisso foi alcançada graças à intermediação de Wilson Rahal, que ao expor que o partido não havia sido capaz de estabelecer uma política sindical contemplando todo o conjunto da militância, não havia motivos para que não se defendesse o "Projeto Mangabeira". Segundo Rahal, naquela conjuntura política em que vivia o país, havia o agravante de que o Congresso pudesse aprovar uma legislação trabalhista ainda pior do que a vigente, sendo, assim, fundamental que o "Projeto Mangabeira" fosse defendido urgentemente pelos socialistas. A proposta de Rahal foi, por fim, aprovada, decidindo-se também que a definição de uma política sindical nacional do PSB ficaria pendente. ${ }^{374}$

Protelações e obstruções por parte dos inimigos do projeto continuaram nos meses seguintes, mesmo após os inúmeros protestos de João Mangabeira contra o retardamento da votação no Congresso. ${ }^{375}$ Casos como o do "Projeto Mangabeira" dão uma mostra das dificuldades que consumiam as energias da militância do PSB ao se chocar contra as estruturas preexistentes do sindicalismo e da legislação brasileira - ainda que a promulgação da Constituição de 1946 possa ter acendido algum fio de esperança quanto a mudanças nesse panorama. Os inimigos eram numerosos e por demais poderosos. Um encolhido PSB, por sua vez, via-se dividindo esforços entre uma atuação externa digna dos seus princípios

\footnotetext{
${ }^{372}$ A Juventude Operária Católica apoia o projeto de Lei Sindical, Folha Socialista, n. 7, 12.05.1958, p. 8.

373 Completa autonomia e liberdade sindicais. Folha Socialista, n. 10, 15.08.1948, p. 1-3.

${ }^{374}$ Completo êxito da II Convenção Estadual do PSB em Campinas. Folha Socialista, n. 12, 20.09.1948, p. 1.

${ }^{375}$ HECKER, op. cit., p. 293-294.
} 
programáticos e pela busca por uma organização que atendesse à disciplina partidária sem prejuízo da democracia interna. ${ }^{376}$

\subsection{Um socialismo democrático à deriva: o PSB na virada da década}

Por diversas vezes, temos nos referido e buscado demonstrar as afinidades conscientemente elaboradas pelo discurso dos socialistas brasileiros com uma imagem que o Partido Trabalhista do Reino Unido lhes parecia representar. Grosso modo, os militantes do PSB consideravam seus pares britânicos e as reformas em curso naquele país como fontes de reserva ideológica que validavam o conceito de socialismo democrático.

Em uma das cartas endereçadas ao Labour Party, a Comissão Nacional do PSB fez elogios ao plano que vinha sendo executado pelos trabalhistas britânicos em direção ao que julgava ser "a consumação da reforma socialista no país". ${ }^{377}$ Em agosto de 1948, um não identificado militante do PSB escreveu ao Labour interessado em saber como o partido tratava, de modo geral, a questão da disciplina interna - assunto que, como vimos, suscitava especial atenção dentro do PSB. A resposta assinada pelo secretário do Departamento Internacional do Partido Trabalhista não fez muitos rodeios:

Com referência à questão da disciplina partidária, devo assinalar que há 394 membros do Partido na Câmara, representando uma extensa variedade de opiniões. Embora seja permitida a expressão de opiniões individuais, torna-se às vezes necessário expulsar algum parlamentar que adote firmemente uma linha hostil ao Governo e aos líderes do Partido ou que transgrida a Constituição partidária. ${ }^{378}$

Na sequência, avançando mais no assunto, o autor da resposta deixa escapar certo grau de elevada autoconfiança de seu partido:

Muitos dos outros partidos socialistas do Continente possuem uma disciplina partidária mais firme que a nossa, o que talvez se deva ao fato de ser muito maior o nosso Partido e muito mais consolidada nossa posição no Governo, de maneira a podermos ser mais tolerantes com os que divergem. ${ }^{379}$

\footnotetext{
${ }^{376}$ A partir de então alguns artigos apresentados na Folha Socialistas buscaram problematizar a relação entre disciplina partidária e democracia interna. Cf. COELHO, Luiz Lopes. A democracia interna exige o respeito aos estatutos partidários. Folha Socialista, n. 43, 15.01.1949, p. 5.

377 Coisas da política. Jornal do Brasil, 07.07.1949, p. 9.

${ }^{378}$ Carta do Partido Trabalhista Inglês ao PSB. Folha Socialista, 05.11.1948, n. 15, p. 6.

${ }^{379}$ Idem.
} 
Mais que do que a mera exposição solícita de diretrizes regimentais partidárias, é interessante notar nessas passagens que, até para assuntos de tal natureza, o Labour Party representava para os socialistas brasileiros uma referência indispensável - e uma referência praticamente imune a críticas, se se considerar a documentação do PSB. Longe de ter uma infinidade de membros no Congresso e mantendo uma posição bastante distante do governo, o PSB reconhecia nos congêneres britânicos um papel central e determinante nas transformações internacionais.

Visualizando uma disputa ideológica na arena internacional, o PSB reconhecia no Reino Unido governado pelos trabalhistas o embrião do "terceiro campo" do socialismo democrático, sob constante ameaça dos imperialismos norte-americano e soviético. Em artigo para a Folha Socialista, Aziz Simão, participante da criação do PSB em São Paulo, apontava o que seriam os riscos da apropriação da planificação econômica por parte dos inimigos do socialismo democrático. Para o sociólogo, o alegado "capitalismo de Estado" soviético e o Estado monopolista norte-americano corriam em uma mesma direção às sociedades totalitárias supressoras das liberdades individuais. Aos socialistas democráticos, prosseguia Aziz Simão, não caberia o papel destruidor de negar os avanços democráticos arrancados da ordem burguesa, ora em degeneração, mas de se reivindicarem herdeiros da civilização e solucionadores da crise civilizatória. Assim, a solução desta crise estaria na planificação conjugada com o exercício pleno da democracia, quer dizer, "com as garantias do controle da produção e da distribuição por parte de órgãos populares democraticamente constituídos". ${ }^{380} \mathrm{O}$ exemplo, uma vez mais, vinha do Reino Unido. Segundo Aziz Simão:

A socialização na Inglaterra é a primeira grande demonstração de que o
socialismo, inseparável da democracia, garante-lhe o pleno exercício. Sob o
peso dos graves problemas herdados do período capitalista, não agindo num
mundo socialista, mas lutando por ele, a política trabalhista inglesa não está a
salvo de críticas, nem coloca acima delas seus representantes no governo.
Todavia, as críticas até agora feitas - quando não vêm do campo totalitário -
se referem a pontos de execução do empreendimento e não à sua orientação
fundamental. E essa livre manifestação de divergências é, para os socialistas,
uma prova irrefutável do regime escorado pelo velho e experiente proletariado
inglês. ${ }^{381}$ Talvez menos otimista com relação às forças de que dispunha o socialismo democrático para vencer uma batalha bifronte, Febus Gikovate ressentia-se com o imobilismo e a descoordenação que, em sua opinião, tornavam os partidos social-democratas europeus meros

\footnotetext{
${ }^{380}$ SIMÃO, Aziz. Socialismo e internacionalismo. Folha Socialista, n. 25, 05.04.1949, p. 4.

381 Idem.
} 
coadjuvantes das transformações econômicas e políticas naquele continente. Na perspectiva do socialista paulista, aqueles partidos tinham se tornado mais mediadores de duas potências mundiais do que portadores de uma política independente - e que caminhasse para uma Europa unificada em bases socialistas. De um lado, estaria a "fraseologia democrática" dos comunistas, como tática para a "preparação do terreno para a instauração de um governo totalitário e monopartidário". Do outro, os EUA com sua Doutrina Truman, favorecendo-se da política de alarmar a população contra a ameaça soviética e propiciando, assim, o crescente armamento na região.

Mas para Gikovate, o Plano Marshall tinha se tornado "a arma mais poderosa que os Estados Unidos lançam mão nessa fase de guerra fria contra a Rússia”, evitando uma crise que afetasse o mercado europeu pretendido pela gigantesca indústria norte-americana, e promovendo a pacificação do clima político instável, que só poderia favorecer a crescente influência comunista. Apesar desses apontamentos, Gikovate considerava o Plano Marshall fundamental para o reerguimento econômico da Europa, desde que sua aceitação pelos governos estivesse "condicionada à absoluta independência política", e que nos recursos obtidos fossem "utilizados para ampliar e solidificar as conquistas socialistas no terreno econômico". 382

O reconhecimento do papel que o PSB desejava ver o Labour Party cumprir transcendia o plano das análises internacionais e introduzia-se até mesmo na política mais cotidiana do partido. Quando, em 1950, os socialistas paulistas confirmaram seu apoio à candidatura de Prestes Maia (UDN) ao governo do estado, o candidato foi perguntado pela Folha Socialista o porquê da aceitação dos pontos mínimos exigidos pelo PSB para a conformação da aliança. Em resposta que mereceu grande destaque do jornal, Prestes Maia declarou:

A orientação socialista se tem imposto de modo crescente no mundo, incrementando e aperfeiçoando, de um lado, os programas assistenciais, e divulgando e facilitando, por outro, gradualmente, conquistas econômicas, políticas e sociais. \# Menos ligado do que qualquer outro candidato às condições conservadoras do país e do momento, presumimo-nos, por isso mesmo, mais aptos que eles à mais perfeita e equitativa compreensão do socialismo em geral, e em particular, das suas aplicações a meios como o nosso que, embora menos preparados, não poderão se eximir, com o tempo, da participação em correntes mundiais que na Inglaterra e outros países estão fazendo sua prova. ${ }^{383}$

\footnotetext{
382 GIKOVATE, Febus. Da crise na Tchecoslováquia ao discurso de Truman. Folha Socialista, n.6, 10.04.1948, p. 8.

${ }^{383}$ Impõe-se de modo crescente no mundo a orientação socialista. Folha Socialista, n. 53, 23.06.1950, p. 2.
} 
O episódio é um sinal de que, além das questões políticas mais elementares, o aspecto internacional imiscuído nas crenças dos socialistas até o início dos anos 1950 tomava um lugar de primeiro plano para o acerto de afinidades políticas com outros interlocutores. No final de 1948, o PSB paulista lançou um documento contendo sua posição em face da situação internacional, reiterando a rejeição aos dois blocos mundiais hegemônicos que, segundo o partido, previam a universalização dos seus modelos de dominação. Em seguida, o documento buscou definir o lugar do internacionalismo socialista ao declarar que, embora os socialistas tivessem objetivos nacionais, uma aliança internacional era importante devido ao caráter mundial que sua luta política tomava. Nessa perspectiva, os partidos socialistas seriam "potencialmente membros dum grande partido internacional que, por certo, em breve encontrará sua expressão estrutural própria". Finalmente, os paulistas "recomendavam" que as táticas e alianças dos partidos socialistas em nome de certas liberdades fossem sempre justificadas pelo resultado maior que se persegue: "a causa do socialismo e da liberdade". 384

Pelo que se constata, os socialistas de São Paulo emprestavam a sua análise internacional alguns de seus dilemas domésticos, notadamente aqueles referentes ao respeito programático nas alianças políticas. Contudo, a aposta na construção do "terceiro campo" manteve-se uma constante para o conjunto do PSB em sua fase inicial, e possivelmente uma válvula de escape para as dificuldades encontradas pelo partido para estabelecer um lugar ao sol no cenário político brasileiro. Em outras palavras, como já nos referimos, a conjugação de metas internas e externas do socialismo democrático poderia servir tanto para a coesão dos socialistas brasileiros quanto para adiar o seu sucesso a um futuro incerto. À diferença dos Partidos Comunistas, no entanto, que dispunham da "pátria do proletariado" para os mesmos propósitos, os socialistas tinham pela frente um terreno por construir, sobrevindo mais incertezas do que certezas.

Por outro lado, iniciativas como a Conferência Internacional Socialista, realizada na Antuérpia entre novembro e dezembro de 1947, e amplamente divulgada na Folha Socialista, além das outras conferências que se seguiram, devem ter dado alguma esperança à militância do PSB em ver uma política unitária sendo implementada pelos partidos socialistas com o objetivo da criação do "terceiro campo" internacional. Mas se o PSB imaginava poder ser o tributário brasileiro no processo de arregimentação das forças socialistas ao redor do mundo, um fato, porém, representou um duro golpe nessa pretensão. Quando foi anunciada a realização

\footnotetext{
${ }^{384}$ A posição do PSB em face da situação internacional. Folha Socialista, n. 17, 05.12.1948, p. 6.
} 
em 1950 do Congresso Mundial dos Trabalhadores Democráticos, em Londres, o convite à participação foi estendido aos representantes sindicais brasileiros, ou seja, aos "amarelos" do sindicalismo ministerialista. Indignado, Domingos Vellasco protestou na Câmara dos Deputados dizendo que era preferível que o Brasil não enviasse qualquer delegação, ao invés de fazer representar seus trabalhadores por sindicatos sob intervenção do governo ou por direções que viviam de esbanjar o imposto sindical. O deputado disse, ainda, que esse era mais um dos motivos pelos quais urgia aprovar o "Projeto Mangabeira", acrescentando que "uma tal representação de certo irá envergonhar o Brasil na Inglaterra. ${ }^{385}$

Não demorou muito, porém, para que a injustiça fosse desfeita. Em maio de 1950, a Folha Socialista publicou em sua primeira página o convite feito ao PSB para que o partido ingressasse no Comitê da Conferência Socialista Internacional - órgão criado a partir da Conferência Internacional Socialista mencionada acima. O convite era assinado por Julius Braunthall, na época secretário-geral do órgão e futuro presidente da Internacional Socialista, reconstruída em 1951. A Comissão Executiva Nacional do PSB decidiu, então, nomear Hermes Lima e Mario Pedrosa - este último com prévia experiência internacionalista acumulada no movimento trotskista - para examinar o assunto. ${ }^{386}$ Ainda que o artigo apontasse que a tendência dominante no partido era pela aceitação do convite, não há registros de que o PSB tenha feito parte das organizações socialistas internacionais.

Nas eleições gerais de 23 de fevereiro de 1950, o Labour Party conseguiu reafirmar-se no governo por uma diferença apertada de votos em relação aos conservadores. Um artigo da Folha Socialista buscou, contudo, minimizar o fato, atribuindo o desempenho dos conservadores aos esforços dos EUA para arrancar os trabalhistas do poder. Para isso os norteamericanos teriam montado uma campanha milionária, elevando Churchill à condição de herói nacional para, assim, reativar o espírito imperialista no Reino Unido. Inúteis esforços, prosseguiu o autor do artigo, uma vez que o Reino Unido, “que até há bem pouco tempo parecia a cidadela inexpugnável do capitalismo, caiu sob a pressão das aspirações socialistas das massas, latentes, ou manifestadas exigentemente em todos os países". Eufórico, o autor emendou que a vitória trabalhista prenunciaria o fim "dos regimes baseados na apropriação dos bens coletivos por uma minoria astuta e afortunada", pois, "as massas, conscientes já de sua

\footnotetext{
${ }^{385}$ Domingos Vellasco denuncia a intrusão dos agentes ministerialistas no Congresso Sindical de Londres. Folha Socialista, n. 42, 01.01.1950, p. 8 e 2.

386 O Partido Socialista Brasileiro convidado a ingressar no COMISCO. Folha Socialista, n. 51, 20.05.1950, p. 1 e 4 .
} 
força, tão expressivamente manifestadas nas eleições inglesas, deverão crer que o mundo não tardará a ser um só para todos, e não para uma minoria privilegiada, apenas". 387

Quando a Folha Socialista parou de circular - deixando de ser uma fonte fundamental das análises do PSB sobre a conjuntura internacional, dentre outros assuntos - um mês havia transcorrido desde o pífio resultado obtido por João Mangabeira na eleição presidencial de 1950. O fracasso da votação do candidato socialista abriu um grande debate interno no PSB, que beneficiou os setores que advogavam novas estratégias eleitorais em detrimento do puritanismo programático (ver Capítulo II, item 2.3).

Para abalar ainda mais a fé dos partidários do socialismo democrático, a chegada de Getúlio Vargas à presidência da República ocorreu no mesmo ano em que o Labour Party, após ter convocado novas eleições gerais, sofreu uma dramática derrota no pleito que trouxe de volta ao governo os conservadores liderados por Winston Churchill. Os trabalhistas apenas voltariam ao poder nas eleições de outubro 1964, sob a liderança Harold Wilson, momento em que, no Brasil, os militares já dominavam a cena. Ainda que não tenhamos acesso a uma avaliação dos socialistas debruçando-se sobre o significado dessas mudanças, é certo que o novo cenário trouxe grandes desesperanças em quem balizava sua atuação política com a previsão do triunfo internacional do socialismo democrático.

${ }^{387}$ GONDIN, Monteiro. O sentido da vitória trabalhista. Folha Socialista, n. 47, 20.03.1950, p. 8. 


\section{Conclusão}

No imediato segundo pós-guerra, muitas incertezas marcaram os defensores do socialismo democrático no mundo todo. No Ocidente da Europa, um quadro de exaustão social e a imposição de uma nova ordem internacional, baseada no instável equilíbrio de forças entre duas potências mundiais, forçaram os partidos social-democratas a atuar com cautela diante de seu eleitorado. No Reino Unido, as responsabilidades crescentes resultantes da aceitação popular, conquistada em um longo período de acomodações à democracia liberal, levaram o triunfante Labour Party ao caminho do reformismo moderado, da preservação de seu "capital político" e, consequentemente, do compromisso de não abalar as bases de sustentação da ordem econômica e social. As reformas que levaram à emergência do Estado de bem-estar social foram capitalizadas como uma vitória do socialismo democrático e dos trabalhadores, embora tal interpretação dos fatos correspondesse a apenas um dos aspectos históricos que constituíram aquele novo modelo de Estado.

No outro polo, conservadores e elites econômicas não tiveram maiores motivos para temores, uma vez que os índices positivos de crescimento econômico e de produtividade mantidos por mais de três décadas -, ao lado da relativa, mas inédita, tranquilidade social, indicavam que o novo "contrato social" não continha elementos que lhes fossem tão desfavoráveis. Afastavam-se as hesitações do entre-guerras em relação às premissas lançadas por uma nova geração de economistas e policy makers que advogavam uma inflexão do papel do Estado na economia, o que, aliás, começou a ocorrer ainda durante a Segunda Guerra - como pelo efeito produzido pela divulgação do Relatório Beveridge.

No entanto, poderia parecer surpreendente que as transformações do Welfare State ocorressem na outrora hegemônica potência capitalista e imperialista, a oficina do mundo contemporâneo durante mais de dois séculos. A nova guinada da política britânica levou à suposição - como no caso dos socialistas brasileiros - de que, enfim, o projeto reformista da Segunda Internacional Socialista era exequível e viável. Nessa perspectiva começava a se esboçar, para uma parte da esquerda, uma alternativa real ao regime implantado na União Soviética, cuja caracterização pelo PSB baseava-se na ideia de que ali se formara um “capitalismo de Estado", não uma verdadeira sociedade socialista. Em entrevista recente, o velho militante socialista Antonio Candido, citado várias vezes neste trabalho, sustentou a polêmica tese de que o resultado principal da Revolução Russa foi o de permitir a formação do 
capitalismo sobre o cadáver então insepulto do regime czarista. ${ }^{388}$ De certa forma, ainda que com perspectivas um tanto distintas, a mesma suposição já havia sido lançada quando os intelectuais do PSB igualavam os efeitos do "capitalismo de Estado" soviético com os do capitalismo monopolista, ambos concebidos como regimes destinados a provocar um retrocesso das conquistas democráticas e dos direitos sociais até então alcançados.

Todavia, os trabalhistas britânicos pareciam repetir outro elemento crucial forjado pelo socialismo no final século XIX: o pragmatismo tendente a adiar a definição dos seus objetivos. Assim, a recusa ao modelo soviético não impedia a reedição de teses internacionalistas para o socialismo democrático, que poderiam servir até mesmo como contenção às simpatias angariadas pelo comunismo no Ocidente. Mas talvez a mesma recusa tenha acelerado a adoção da noção de que o único espaço para a atuação dos socialistas era a vida política nacional, com os novos métodos de planejamento que a macroeconomia dispunha. Em meio às incertezas do segundo pós-guerra, essa parecia ser a certeza na qual os socialistas podiam se apegar com alguma segurança.

Como indivíduos de seu tempo, os socialistas brasileiros, ao formarem a Esquerda Democrática em 1945, lançaram mão dos elementos teórico-políticos que estavam disponíveis naquele momento e, com isso, formularam metas originais para sua militância nas condições específicas da realidade nacional. Intelectuais como os que se agruparam em torno da Folha Socialista e do Vanguarda Socialista percorreram diferentes domínios teóricos com certa desenvoltura, submetendo o Brasil a radiografias que possivelmente lançaram as bases para futuras e importantes teses sobre instituições políticas e sociais brasileiras. É o que se observa, por exemplo, na similaridade das análises socialistas sobre a estrutura sindical brasileira criada no Estado Novo com conceitos e ideias desenvolvidos pelos expoentes da chamada Escola Paulista de Sociologia.

A principal dificuldade dos socialistas brasileiros não residia exatamente na definição de seu norte teórico e ideológico. Enquanto os comunistas, na maior parte das vezes, contavam com um influente patrimônio doutrinário e com o prestígio de seu líder carismático, o PSB, com pouca influência nos meios operários, contava principalmente com o concurso das suas teses e propostas, ainda que não se deva desprezar a força dos socialistas nos meios sindical e estudantil, sobretudo a partir da segunda metade da década de 1950. O dilema principal era,

$\overline{388} \mathrm{O}$ socialismo é uma doutrina triunfante. Brasil de Fato, 08.11.2011. 
portanto, o de definir qual projeto organizacional poderia ser capaz de implementar, no Brasil, o ideário básico do socialismo democrático de meados do século XX.

É impossível descartar as diferenças de visões, dentro do PSB que, de alguma maneira, tentaram apropriarem-se da experiência de formação do Estado de Bem-Estar Social no Reino Unido. Entre 1945 e 1950, ideias acerca da estatização, do conceito de socialização e do partido ideal para colocar em prática as tarefas do socialismo democrático foram sendo formuladas de maneira ambígua e conflituosa pelo partido, em que pese todo o cuidado com as definições programáticas. As evidências apresentadas nos capítulos da dissertação sugerem que essas diferenças de visão eram de natureza tão profunda que, se não fossem a legislação eleitoral e a escassez de quadros socialistas no Brasil, certamente os grupos embrionários da Esquerda Democrática jamais teriam se unido. Naquele momento do imediato pós-guerra, entretanto, o apelo ao exemplo britânico revelou-se um importante ponto de coesão e compromisso programático, permitindo que a teoria produzida pelos socialistas pudesse se desenvolver aplicada a objetivos práticos.

A adoção de um modelo de partido abrangente, não-dogmático e, por conta disso, comparável ao Labour Party, foi celebrado como uma virtude, principalmente pelos membros liberal-socializantes que predominaram na Comissão Nacional do PSB. Além desse princípio, havia também um outro, um tanto óbvio, professado com frequência nas páginas dos jornais socialistas, que entendia que o crescimento do partido deveria basear-se nas demandas produzidas pela própria classe trabalhadora, e não por cima ou em nome delas. Mas era difícil prever um casamento tranquilo entre os dois princípios, quando, entre materialismos e idealismos, um agrupamento relativamente pequeno era marcado por uma irremediável heterogeneidade. A intensidade e o teor dos debates internos, sujeitos à difícil tarefa de estreitar os vínculos com o conjunto da classe trabalhadora, não escondem o fato de que durante toda a sua trajetória o partido viveu em franca e acirrada disputa interna.

As crises entre os socialistas apareceram de forma abrupta, por exemplo, durante as reuniões e convenções convocadas para decidir sua posição nas eleições presidenciais. Esse é um claro sinal de fragmentação, que atesta as dificuldades do projeto político socialista no Brasil e a existência de uma enorme suscetibilidade em relação às circunstâncias externas ao partido. Antes da primeira polêmica sobre a sucessão presidencial, em 1950, uma relativa harmonia foi mantida desde 1945, em parte devido à existência de uma fonte de princípios comuns, encontrada no programa da social-democracia europeia. 
Na instalação da Constituinte de 1946, a Esquerda Democrática ainda não havia realizado sequer sua I Convenção Nacional. Os eleitos do novo grupo socialista mantinham vínculos com o universo liberal brasileiro, ou mesmo com o utilitarismo, mais perceptíveis quando se advogava a introdução de normativas técnicas e de planejamento econômico para que a democracia pudesse se consolidar combinada à justiça social. Nesse aspecto havia uma diferença importante com os comunistas: estes, com seu maior suporte social, defendiam liberdades democráticas como condição da sua própria existência, enquanto os socialistas projetavam medidas contando apenas com a possibilidade remota do sucesso de seu programa. Assim, enquanto o grupo do Vanguarda Socialista concebia a possibilidade de estender as demandas dos socialistas para ruas e fábricas, um cético Hermes Lima confessava depositar poucas esperanças na Assembleia Constituinte, preferindo aderir às muitas vozes que se espelhavam nas Constituições anteriores como forma de retomar o que teria sido a evolução democrática interrompida pelo golpe do Estado Novo.

Sob tais circunstâncias, os socialistas adiavam para depois da Assembleia Constituinte a defesa de propostas mais identificadas com a socialização progressiva dos meios de produção e com a participação da população na gestão direta do Estado, duas bandeiras caras ao novo grupo político. Nesse interregno, no entanto, o caso da celebrada formação de uma comissão de trabalhadores da Light para intervir nos trabalhos constituintes representou para os socialistas um exemplo, ainda que bastante singular, do tipo de experiência de organização dos trabalhadores que seus partidários viam como modelo a ser perseguido no futuro. Ou mesmo uma antecipação do que deveria ser a natureza do regime democrático no Brasil.

Todavia, a reação do governo Dutra às tentativas de reorganização dos sindicatos, o clima geral de congraçamento de praticamente todos os espectros políticos dando vivas à democracia, além de um disseminado anticomunismo, foram elementos que, somados, dificultaram a diferenciação dos socialistas frente aos demais partidos e correntes de opinião. Por um lado, os socialistas defendiam a necessidade de consolidar o espírito democrático pós1945, mas, por outro, a defesa de alguns pontos em comum com os comunistas, tais como amplas liberdades democráticas e uma reforma agrária, também tornaram o PSB um alvo constante dos ataques de parlamentares e da imprensa mais conservadora.

Nos anos seguintes, o confronto entre os conceitos de nacionalização e estatização - que começou a se esboçar ainda durante a Constituinte - contribuiu para definir com maior exatidão o que o PSB entendia por socialização progressiva dos meios de produção. Entretanto, o rigor teórico que orientou os debates não refletiu um fortalecimento da identidade do partido na vida 
política nacional. Com o decisivo reforço da produção teórica dos paulistas do Folha Socialista, a ênfase do projeto socialista concentrou-se na crítica aos monopólios econômicos, incluindo aqueles dominados pelos capitalistas nacionais. A adoção dessas diretrizes não se deu sem percalços, como os verificados nas polêmicas em torno da campanha do petróleo e da formulação da reforma da lei sindical. Superadas as controvérsias, ao menos no nível teórico, a perspectiva central dos socialistas consistia em retirar todos os obstáculos à participação dos trabalhadores na economia. Desta forma, os socialistas reivindicavam-se verdadeiramente revolucionários no seu reformismo, pois em contraste com os comunistas não defendiam o desenvolvimento econômico por meio da conciliação de classes e a manutenção de um movimento sindical anti-autonomista, conforme se referiam à linha política seguida tanto pelos comunistas como pelos trabalhistas.

É possível acrescentar também que as referências à conjuntura internacional serviram para orientar a crítica a esses adversários, uma vez que a denúncia a setores identificados com práticas personalistas e populistas inseria-se em uma concepção de que, daquele momento em diante, o processo histórico mundial não poderia sujeitar os movimentos dos trabalhadores à tutela que impediria a plena realização da nova ordem democrática.

Logo na entrada da década de 1950, verifica-se um ponto de desgaste do otimismo inicial dos socialistas com os acontecimentos na Europa. A partir do desgaste da eleição presidencial de 1950 e a subsequente adoção de táticas que abririam a possibilidade de distintas coligações eleitorais, o PSB começou a caminhar na direção de leituras que identificavam as soluções para os problemas brasileiros mais nos fatores da dinâmica interna do país do que em esquemas associados a mudanças no padrão de desenvolvimento econômico e na evolução de política internacionais. Com o pensamento nacional-desenvolvimentista ganhando espaço em meados da década, continuar gravitando na órbita liberal tornou-se um contrassenso para a maior parte dos socialistas, demarcando uma mudança de atitude em face do próprio conceito de democracia. Por sua vez, o efeito da Revolução Cubana, a partir de 1959, e o apelo antiimperialista radical que recaiu sobre a esquerda brasileira contribuíam para que os socialistas também buscassem associar mais estreitamente seus rumos com os acontecimentos da América Latina. Nesse período, os militantes do PSB realizaram uma série de movimentos desconexos, até que o golpe de 1964 e seus desenvolvimentos posteriores barrassem todos os tipos de aspiração democráticas, nacionalista-populares ou revolucionárias.

É assumido normalmente pela historiografia que a tradição social-democrata, ou do socialismo democrático, não teve vazão na política brasileira. O argumento é razoável ao se 
basear na ausência de setores preponderantes na vida política nacional que tenham assumido tal matriz teórico-política com tudo o que ela representou até a metade do século XX. No Brasil, diferentemente da Europa, o caráter das instituições públicas, e os interesses mais bemcolocados em torno delas, foram identificados pelos próprios socialistas como obstáculos para os aperfeiçoamentos democráticos reivindicados com entusiasmo pelo PSB em sua fase inicial. Aspectos relacionados à construção do Estado de Bem-Estar Social no Reino Unido forneceram um modelo ainda em desenvolvimento daquilo que os socialistas esperavam um dia ver concretizado no Brasil. Nessa perspectiva, entre 1945 e 1950, o PSB atuou de fato como herdeiro das tradições europeias reivindicadas pelo partido, mas tendo que somar ao ideário internacional fundamentos de uma militância socialista genuinamente brasileira. Essa noção permite alargar um pouco mais as considerações em torno do PSB de modo que se possa verificar, pela ótica do partido, percepções originais acerca da relação entre Estado e sociedade no período em questão.

É precisamente nos anos 1940 que a força da ideologia do PSB permitiu ao partido ser mais do que um agrupamento de tamanho modesto, de interesses facilmente permutáveis e em busca prioritária por um lugar de destaque na política brasileira. O levantamento de objetivos claros, mesmo em meio aos intensos conflitos internos, permitiu aos socialistas elaborar reflexões inovadoras acerca de diversos temas, aqui abordados, como a diferenciação do papel do Estado e dos trabalhadores na organização da economia nacional, a reforma agrária como um objetivo já socialista e a tutela ministerial sobre os sindicatos como uma herança estadonovista oposta à realização da democracia.

Tais temas que, aliás, atravessaram o tempo. Quando o Partido dos Trabalhadores (PT) foi fundado, durante o processo de abertura da ditadura militar e da crise do chamado socialismo real, novas expectativas surgiram em torno da reafirmação de um modelo de partido democrático, realmente alicerçado nas lutas da classe trabalhadora. $\mathrm{O}$ velho militante socialista Mario Pedrosa, ao ser o primeiro signatário do manifesto de fundação do PT, poderia simbolizar pessoalmente a confluência dos pressupostos do novo partido com as aspirações socialistas democráticas de meados da década de 1940. Sob muitos aspectos, tais aspirações foram revigoradas por frações do movimento operário e da intelectualidade do final dos anos 1970 e início dos 1980. Algumas dessas aspirações referiam-se à reivindicação da autonomia sindical e à superação das formas de tutela sobre a classe trabalhadora, sejam elas exercidas através do Estado ou por forças políticas associadas ao populismo. 
Em meio às múltiplas divergências entre os atores que animavam o PT, conformaramse as correntes internas como meio de satisfazer as diferenças que se acumulavam em face da nova empreitada da esquerda brasileira. Ao passo que as organizações representantes das classes trabalhadoras amargavam sucessivas derrotas, frustrações e certo descrédito a partir dos anos 1980, a inclinação por um projeto reformista prevaleceu, e as gradações de radicalismo sucumbiram pouco a pouco conforme setores mais moderados viabilizaram, com idas e vindas, seu projeto específico de chegada ao poder. Atingido esse objetivo, o pragmatismo das políticas pró-mercado sobrepujou as ambições por reformas sociais que, por algum tempo, rodearam o PT. Quando o "bem-estar” já havia se tornado um conceito gasto, a ideia de um planejamento econômico mais "socializante" não demonstrou vitalidade, ainda que tal figurasse como tese de governo.

Advindos os efeitos mais contundentes da crise econômica e o esfacelamento do projeto petista, a emergência - via compilação de métodos amplamente questionáveis -, neste ano de 2016, de um governo claramente identificado com os setores conservadores da sociedade brasileira, reacendem e atualizam as discussões acerca da relação entre desenvolvimento econômico e conquistas sociais. No mundo inteiro, planos de austeridade combinados com revisões da legislação trabalhista e de demais direitos lançam muitas incertezas quanto à capacidade de as políticas pró-mercado serem capazes de conter a exaustão e a revolta social. 


\section{BIBLIOGRAFIA GERAL}

\section{Periódicos}

Correio da Manhã

Daily Herald

Diário de Notícias

Folha da Manhã

Folha da Noite

Folha Socialista

Jornal do Brasil

Novos Rumos

O Jornal

The Spectator

Vanguarda Socialista

\section{Acervos e Arquivos}

Arquivo Público do Estado do Rio de Janeiro

Arquivo Público do Estado de São Paulo

Biblioteca Digital da Câmara dos Deputados <http://bd.camara.leg.br/>

Centro de Documentação e Memória da Universidade Estadual de São Paulo

Centro de Pesquisa e Documentação em História Contemporânea da Fundação Getúlio Vargas $<$ http://cpdoc.fgv.br/>

Folha de São Paulo <http://acervo.folha.uol.com.br/>

Hemeroteca da Biblioteca Nacional <http://bndigital.bn.br/hemeroteca-digital/>

The Spectator <http://archive.spectator.co.uk/> 


\section{Referências}

ADDISON, Paul. The Road to 1945: British Politics and the Second World War. London: Quartet, 1977.

ALDCROFT, Derek H. The European economy 1914-2000. 4ª .ed. London: Routledge, 2001.

ALEM, Silvio Frank. Contribuição à história da esquerda brasileira: o Partido Socialista Brasileiro (1945-1964). Tese de doutoramento. São Paulo: FFLCH/USP, 1998.

ALMINO, João. Era uma vez uma Constituinte: lições de 1946 e questões de hoje. São Paulo: Brasiliense, 1985.

BALEEIRO, Aliomar. A Constituinte e a Constituição Federal de 1946. In: BALEEIRO, Aliomar; SOBRINHO, Barbosa Lima (Orgs.). Constituições brasileiras: 1946. Brasília: Senado Federal, 2001.

BENEVIDES, Maria Victoria. A UDN e o udenismo: ambiguidades do liberalismo brasileiro (1945-1965). Rio de Janeiro: Paz e Terra, 1981.

BIELSCHOWSKY, Ricardo. Pensamento econômico brasileiro: o ciclo ideológico do desenvolvimentismo. 5.ed. Rio de Janeiro: Contraponto, 2004.

BRAGA, Sérgio Soares. Quem foi quem na Assembleia Constituinte de 1946. Brasília (DF): Câmara dos Deputados, 1998.

BRASIL. Constituição Federal de 1934.

BRASIL. Constituição Federal de 1946.

BUTLER, Geoffrey; MACCOBY, Simon. The development of international law. New Jersey: The Lawbook Exchange, 2003.

CANDIDO, Antonio. Recortes. São Paulo: Companhia das Letras, 1993.

CANDIDO, Antonio. Informe político. In: CALIL, Carlos Augusto; MACHADO, Maria Teresa (Orgs.). Paulo Emílio: um intelectual na linha de frente. São Paulo: Cia das Letras, 1993.

CARDOSO, Fábio Luiz Lopes. A influência do Relatório Beveridge nas origens do Welfare State (1942-1950). Revista Todavia, Ano 1, n. 1, jul. 2010, p. 39-53.

CARONE, Edgard. Movimento operário no Brasil (1945-1964). São Paulo: Difel, 1981.

CARONE, Edgard. $O P C B: 1943$ a 1964. v. 2. São Paulo: Difel, 1982.

CARR, Edward H. Vinte anos de crise: 1919-1939. Uma introdução ao estudo das relações internacionais. 2.ed. Brasília (DF): UnB, 2001. 
CODOVILLA, Vitorio. "Os comunistas argentinos e o peronismo". Apud LÖWY, Michael. $O$ marxismo na América Latina. Uma antologia de 1909 aos dias atuais. 2.ed. São Paulo: Perseu Abramo, 2006.

COSTA, Dante. O Socialismo. Rio de Janeiro: Organizações Simões, 1954.

DELGADO, Lucília Neves de Almeida. Nacionalismo como projeto de nação: a Frente Parlamentar Nacionalista (1956-1964). In: FERREIRA, Jorge; REIS, Daniel Aarão (Orgs.). As esquerdas no Brasil: nacionalismo e reformismo radical. 1945-1964. Rio de Janeiro: Civilização Brasileira, 2007, v. 2.

DIAS, José Luciano de Mattos; QUAGLINO, Maria Ana. A questão do petróleo no Brasil: uma história da Petrobrás. Rio de Janeiro: CPDOC/Serinst, FGV/Petrobras, 1993.

DUARTE, José. A Constituição brasileira de 1946. Exegese dos textos à luz dos trabalhos da Assembleia Constituinte. Vol. 1. Rio de Janeiro: Imprensa Nacional, 1947.

FEINSTEIN, Charles H; et al. The world economy between the World Wars. Oxford: University Press, 2008, p. 25-26.

GIKOVATE, Febus. A campanha em prol do petróleo nacional. In: PSB. Posições Socialistas. São Paulo: Edições do PSB (Seção Paulista), 1949, p. 71-72.

GOMES, Angela de Castro. A invenção do trabalhismo. Rio de Janeiro: FGV, 2005.

GORENDER, Jacob. Combate nas trevas. A esquerda brasileira: das ilusões perdidas à luta armada. 5.ed. São Paulo: Fundação Perseu Abramo: Expressão Popular, 2012.

GUSTIN, Miracy B. S.; VIEIRA, Margarida L. M. Semeando a democracia: a trajetória do socialismo democrático no Brasil. Contagem (MG): Palesa, 1995.

HECKER, Alexandre. Socialismo sociável: história da Esquerda Democrática em São Paulo. São Paulo: UNESP, 1998.

HOBSBAWM, Eric. A era dos extremos: o breve século XX. Tradução de Marcos Santarrita. São Paulo: Companhia das Letras, 1994.

HOBSBWAM, Eric. A era dos impérios 1875-1914. Tradução de Sieni Maria Campos e Yolanda Steidel de Toledo. 13.ed. Rio de Janeiro: Paz e Terra, 2009.

JENKINS, Clive. O Estado de bem-estar: objetivos, realizações e deficiências. Cadernos da UnB, 1982.

KOLB, Eberhard. The Weimar Republic. $2^{\mathrm{a}}$.ed. London: Routledge, 2005.

LICHTHEIM, George. A short history of socialism. Glasgow: Fontana; Collins, 1970.

LOUREIRO, Isabel. A Revolução Alemã, 1918-1923. São Paulo: UNESP, 2005. 
LOUREIRO, Isabel. Mario Pedrosa e o socialismo democrático. In: MARQUES NETO, José C. (Org.). Mario Pedrosa e o Brasil. São Paulo: Fundação Perseu Abramo, 2001.

MAGRI, Lucio. O alfaiate de Ulm: uma possível história do Partido Comunista Italiano. Tradução de Silvia De Bernardinis. São Paulo: Boitempo, 2014.

MAIER, Charles. In search of stability. Explorations in historical political economy. Cambridge: Cambridge University Press, 1987.

MAIER, Charles. The postwar social contract: comment. International Labor and WorkingClass History, n. 50, 1996. Apud COLISTETE, Renato P. "Productivity, wages, and labor politics in Brazil, s1945-1962”. Journal of Economic History, vol. 67 n. ${ }^{\circ}$ 1, 03/2007.

MALLOY, James M. Política de previdência social no Brasil. Rio de Janeiro: Graal, 1986.

MATTOS, André Luiz R. R. Uma história da UNE (1945-1964). Campinas (SP): Pontes, 2014.

MATTOS, Marcelo Badaró. O sindicalismo brasileiro após 1930. Rio de Janeiro: Jorge Zahar, 2003.

MILWARD, Alan S. The reconstruction of Western Europe, 1945-1951. London: Methuen, 1984.

OFFE, Claus. Problemas estruturais do Estado capitalista. Tradução de Bárbara Freitag. Rio de Janeiro: Tempo Brasileiro, 1984.

OWEN, David. O caso da Inglaterra: quais as mudanças ocorridas? Que futuro? Cadernos da UnB. A socialdemocracia alemã e o trabalhismo inglês. Brasília (DF): UnB, 1982.

PRZEWORSKI, Adam; WALLESTEIN, Michael. O capitalismo democrático na encruzilhada. Novos Rumos. n. ${ }^{\circ} 22$, out. 1988.

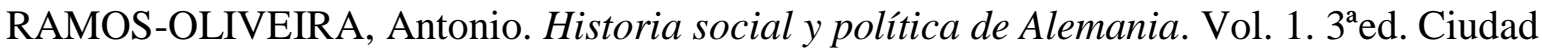
de México: Fondo de Cultura Económica, 1995.

REBERIOUX, Madeleine. O debate sobre a guerra. In: HOBSBAWM, Eric (Org.). História do marxismo: o marxismo na época da Segunda Internacional. Tradução de Leandro Konder. v. 4. 2.ed. Rio de Janeiro: Paz e Terra, 1986.

ROTH, Guenther. The Social Democrats in Imperial Germany: a study in working-class isolation and national integration. New Jersey: Bedminster Press, 1963.

SASSOON, Donald. One hundred years of socialism: the West European Left in the twentieth century. London: I.B. Tauris, 2010.

SIGERIST, Henry. From Bismarck to Beveridge: developments and trends. Journal of Public Health Policy. vol. 20, n. 4, 1943. 
SKIDMORE, Thomas. Brasil: de Getulio a Castelo. Rio de Janeiro: Paz e Terra, 1982.

SOCIALIST LEAGUE. The Paris Congress: a delegate's report. Commonweal, 10 ago. 1889. Disponível em: 〈https://www.marxists.org/archive/kitz/congress.htm>

STEINMETZ, George. The local welfare state: two strategies for social domination in urban Imperial Germany. American Sociological Review, v. 55, n. 6, dez. 1990.

TIMUSS, Richard. Problems of social policy. Official civil history of the Second World War. Londres: 1950. Apud JEFFERYS, Kevin. British politics and social policy during the Second World War. The Historical Journal, vol. 30, n. 1, 1987.

TOLEDO, Caio Navarro de. ISEB: fábrica de ideologias. São Paulo: Ática, 1977.

VELLASCO, Domingos. Rumos Políticos. Rio de Janeiro: Agir, 1946.

VICTOR, Mário. A batalha do petróleo brasileiro. Rio de Janeiro: Civilização Brasileira, 1970.

VINCENT, Paul C. A historical dictionary of Germany's Weimar Republic, 1918-1933. London: Greenwood Press, 1997.

WEFFORT, Francisco. Origens do sindicalismo populista no Brasil. Estudos CEBRAP, n. 4, 1973, p. 04-06.

WILLIAMS, Francis. Fifty years march: the rise of the Labour Party. Londres: Odhams, 1951. Apud FIELDINGS, Steven. What did 'the people' want?: the meaning of the 1945 general election. The Historical Journal, vol. 35, n. 3, 09/1992. 


\section{Anexos}




\section{Anexo 1 \\ Enfrentemos o futuro: uma declaração do Labour Party para a consideração da nação [1945] ${ }^{389}$}

\section{A vitória na guerra deve ser seguida por uma perspectiva de paz}

A vitória está assegurada para nós e nossos aliados na guerra europeia. A guerra no Leste vai pelo mesmo caminho. O Partido Trabalhista Britânico está firmemente seguro de que o barbarismo japonês deve ser derrotado tão decisivamente como foi a agressão e a tirania nazista. O povo terá vencido ambas as lutas. Os homens e mulheres valentes nos Serviços de Combate, na Marinha Mercante, Guarda Doméstica e Defesa Civil, nas fábricas e nas áreas bombardeadas, merecem e devem ter assegurados um futuro mais feliz do que o enfrentado após a última guerra. O Labour compreende o bem-estar como um direito sagrado.

Na medida em que a contribuição britânica foi posta em causa de forma considerável, esta guerra terá sido vencida por seu povo, e não por qualquer homem ou grupo de homens, embora uma grande e valorosa liderança tenha sido delegada aos representantes do povo na presente luta. E nesta liderança os Ministros do Labour assumiram inteiramente sua quota de responsabilidade. O papel dos Ministros do Labour tem sido o de realizar com sucesso difíceis tarefas, desde o fatídico dia, naquele maio de 1940, quando por iniciativa do Labour no Parlamento derrubou-se o Governo Chamberlain e formou-se o novo Governo de Guerra que levou o país à vitória.

Para vencer a última guerra, o povo também realizou tremendos esforços. Mas após a vitória ele abdicou do interesse vivo pelos problemas socioeconômicos do período de paz, aceitando as superficiais promessas eleitorais dos partidos anti-trabalhistas. Assim, os "homens de face dura que se beneficiaram da guerra" conseguiram estabelecer os critérios da paz que mais se adequavam aos seus interesses. ${ }^{390} \mathrm{O}$ povo perdeu a paz. E quando dizemos "paz", nos referimos não apenas a um Tratado, mas à política socioeconômica que segue às batalhas.

\footnotetext{
${ }^{389}$ Extrato da primeira parte do Manifesto do Partido Trabalhista Britânico, em ocasião das eleições gerais de 1945. Fonte: <http://www.politicsresources.net/area/uk/man/lab45.htm>

${ }^{390}$ No original: "hard-faced men who had done well out of the war". Trata-se de uma referência a uma polêmica declaração do conservador Stanley Baldwin, primeiro-ministro do Reino Unido por três vezes entre 1923 e 1937 , referindo-se aos membros do Parlamento, eleitos logo após o fim da I Grande Guerra, em 1918.
} 
Nos anos que se seguiram, os "homens de face dura" e seus amigos políticos mantiveram o controle do Governo. Controlaram os bancos, as minas, as grandes indústrias, grande parte da imprensa e do cinema. Eles controlaram os meios pelos quais o povo sobrevive. Eles controlaram as formas pelas quais a maioria das pessoas aprendem sobre o mundo exterior. Isso ocorreu em todos os grandes países industrializados.

Grandes tempestades econômicas varreram o mundo naqueles anos. Os grandes desastres do entre-guerras não foram atos divinos ou de forças ocultas. Eles foram o resultado óbvio e correspondente à extrema concentração de poder econômico nas mãos de pouquíssimos homens. Estes homens haviam aprendido a agir somente em razão dos interesses de seus próprios monopólios privados burocraticamente dirigidos, em posição comparável ao de uma oligarquia totalitária dentro do nosso Estado democrático. Eles não sentiam a responsabilidade que tinham perante à nação.

Forças similares agem hoje. Porém, os especuladores não têm sido capazes de gerar com esta guerra os mesmos lucros do passado. A propaganda determinada do Partido Trabalhista, apoiado por outras forças progressistas, tem produzido o efeito de "retirar da guerra a questão do lucro". O fisco de $100 \%$ sobre o lucro, os controles sobre a indústria e os transportes, o racionamento honesto de alimentos e o controle dos preços - medidas sem as quais o Partido Trabalhista não teria aderido ao Governo - contribuíram para a vitória na guerra. Com essas medidas o país ficou mais próximo do que nunca de ser dirigido por "ações justas".

Mas a guerra no Oriente ainda não acabou. Grandes saques ainda poderão ocorrer. Um período de crescimento curto depois da guerra, quando a poupança, gratificações e créditos do pósguerra ainda serão gastos, pode representar um paraíso para os aproveitadores. Mas o Grande Negócio sabe que isso só acontecerá se as pessoas votarem no partido que pretende livrar-se dos controles, permitindo aos aproveitadores e chantagistas a liberdade pela qual estão pleiteando eloquentemente em todas as plataformas do Tory e em todos os jornais apoiadores do Tory.

Eles acusam o Partido Trabalhista de querer impor controles apenas por uma questão de controle. Isso não é verdade, e eles sabem disso. O que é verdade é que os que se opõem ao planejamento desejam varrer quaisquer controles públicos simplesmente pelos interesses de garantir aos especuladores e às elites privilegiadas um caminho inteiramente livre para saquear o resto da nação, como fizeram descaradamente na década de 1920. 
Será que a liberdade para o especulador significa liberdade para o homem e a mulher comuns, sejam eles assalariados, empresários de pequeno porte ou profissionais liberais e donas de casa? Basta olhar para trás e observar as depressões dos vinte anos entre as duas guerras, quando os controles públicos de qualquer natureza eram mínimos e os grandes especuladores gozavam de total liberdade. Nunca um dano tão alto foi causado a tanta gente por tão poucos. A liberdade não é uma coisa abstrata. Para ser real ela deve triunfar, deve-se trabalhar pela sua causa.

O Partido Trabalhista está preparado para impedir o caos que se seguiria à liquidação de todo o controle público. Estamos preparados tanto para a construção positiva do progresso como para lutar contra a caótica e anárquica economia do "aja como quiser".

O Partido Trabalhista não faz promessas infundadas. O futuro não será fácil. Mas desta vez a paz deve vencer. O Partido Trabalhista oferece à nação um plano que vai garantir a paz para o povo. 


\section{Anexo 2}

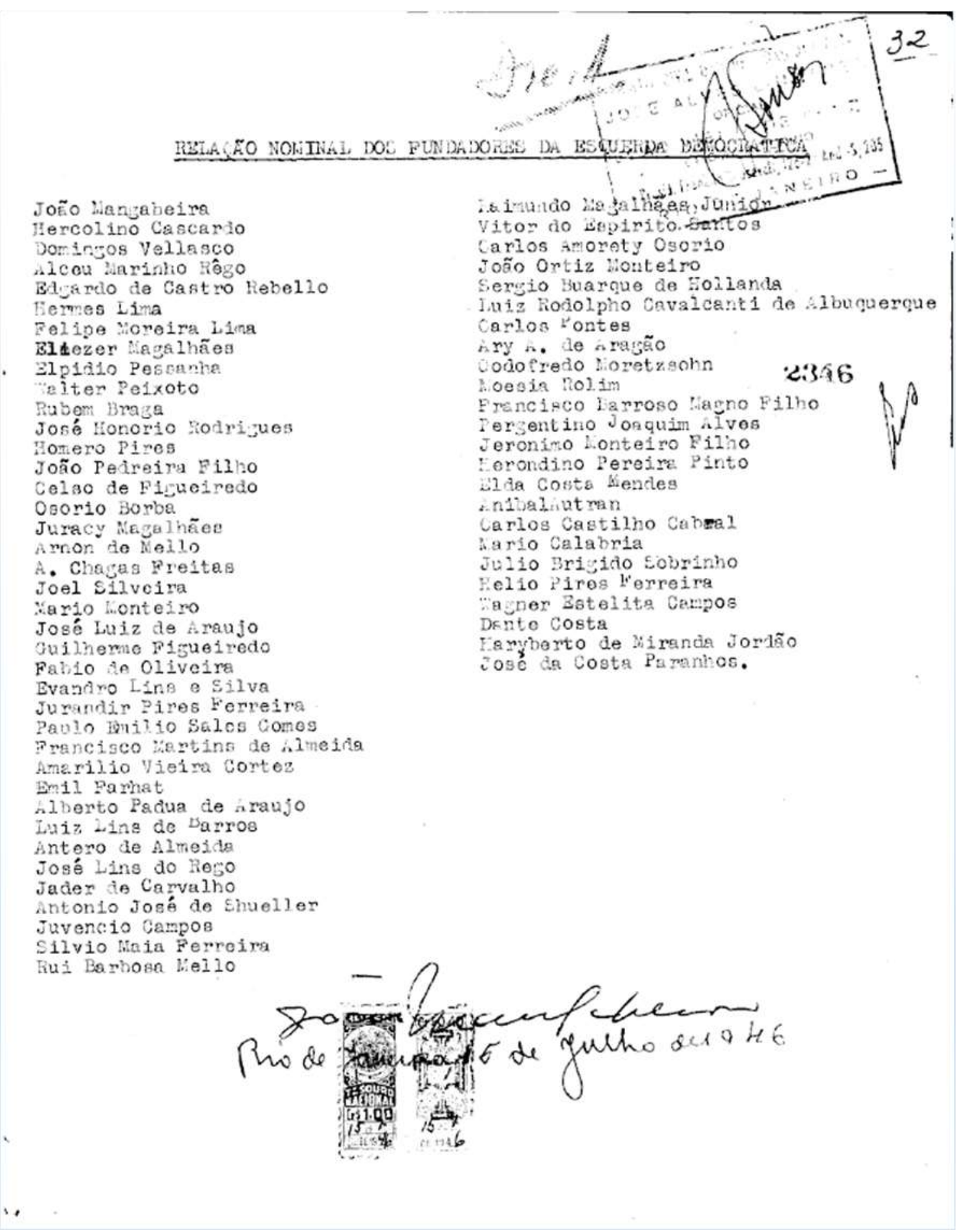

Relação dos fundadores da Esquerda Democrática (documento protocolado no Superior Tribunal Eleitoral em 1946 para fins de registro do partido)

Fonte: <http://www.tse.jus.br/partidos/partidos-politicos/registros-de-partidos-politicos-1945-a-1979> 


\section{Anexo 3}

\section{Manifesto da Esquerda Democrática (24 de agosto de 1945)}

O momento político está exigindo da "Esquerda Democrática" ampla definição dos seus objetivos e processos, tantos são os apelos que, de toda parte do Brasil, ela recebe. Nesses termos, a "Esquerda Democrática" julga oportuno afirmar e precisar as linhas ideológicas fundamentais de seu pensamento político, para completa homogeneidade de seus quadros.

Antes de tudo, o que é a "Esquerda Democrática"?

Não é um partido; mas em partido se transformará. É, por enquanto, segundo ela própria se define, "uma reunião de pessoas e organizações, que aceitam a declaração por ela entregue, em 12 de junho último, ao Brigadeiro Eduardo Gomes, como base mínima de um partido, cujo programa será elaborado pela convenção nacional, que oportunamente se convocará”.

Mas essa reunião de pessoas e organizações, essa corrente política, em suma, é democrática, porque sustenta que, na civilização em que vivemos e pretendemos viver, são fundamentais os seguintes princípios:

a) regime representativo, de origem popular, através do sufrágio universal, direto e secreto, com representação proporcional;

b) liberdade de manifestação do pensamento pela palavra escrita, falada e irradiada; liberdade de organização partidária, liberdade de associação, liberdade de reunião, liberdade de cátedra;

c) liberdade de crença e de cultos, de modo que nenhum deles tenha com o Governo da União ou dos Estados relações de dependência ou aliança;

d) autonomia sindical e direito de greve.

No clamor das reivindicações populares que no mundo inteiro se levantam, há uma nota de vibração particular: a defesa da liberdade civil e política. O ideal democrático surge das ruínas da guerra, de novo, iluminando o mundo. Onde a democracia soçobrou, clama-se por sua restauração imediata, onde se manteve, por sua continuação e seu fortalecimento.

Forma de convívio político, seria absurdo confundir a democracia com determinada ordem econômica. Não foram os postulados da democracia que motivaram a crise do nosso tempo, 
pois não são próprias dela nem as desigualdades sociais, nem o antagonismo de interesse entre as classes. Desigualdades e antagonismo decorrem, isto sim, do liberalismo econômico que pleiteamos transformar, em nome mesmo do ideal democrático.

Conciliar o processo das transformações sociais com as exigências da mais ampla liberdade civil e política, utilizar na realização desse propósito os postulados da democracia e suas instituições - eis o objetivo político da "Esquerda Democrática".

Democrática por seu método e seus objetivos, essa corrente política é igualmente de esquerda, porque sustenta, desde logo, que a propriedade tem, antes de tudo, uma função social, não devendo ser utilizada contra o interesse coletivo; e defende um programa de reforma econômica, inclusive uma gradual e progressiva socialização dos meios de produção, à medida que a exigirem as condições objetivas do desenvolvimento material do País. E tudo isso como expressão da vontade da maioria, manifestada pelo processo democrático.

Como reivindicações imediatas destinadas a melhorar as condições gerais de vida do povo brasileiro, especialmente das classes média e pobre, a "Esquerda Democrática" pleiteia as seguintes medidas:

a) proteção do trabalho sob todas as suas formas, com ampliação e aperfeiçoamento da legislação vigente;

b) salário mínimo justo, capaz de assegurar ao trabalhador a sua manutenção e de sua família e a educação de seus filhos;

c) salário igual para trabalho igual, sem distinção de idade ou sexo;

d) gratuidade do ensino público em todos graus e ramos; organização da escola primária não apenas como órgão de instrução, mas também de assistência social à infância;

e) um plano nacional de defesa da saúde e assistência social ao povo brasileiro, cujas tarefas urgentes e imediatas serão as seguintes: combate à mortalidade infantil, estabelecimento de centros de saúde, formação de enfermeiros e enfermeiras rurais, de modo que nenhum núcleo de população do nosso território se veja privado desses benefícios;

f) supressão de qualquer imposto sobre gêneros alimentícios de primeira necessidade, medicamentos, vestuário indispensável às classes média e pobre, assim como sobre os instrumentos manuais de trabalho do operário urbano ou do trabalhador rural, inclusive os do pequeno agricultor; 
g) plano para construção de casas higiênicas ao alcance do salário do trabalhador, devendo ser, doravante, empregados nesse fim recursos dos institutos de previdência e caixas econômicas;

h) isenção do Imposto de Renda até um mínimo correspondente à manutenção de uma existência digna e eficiente, tomada como padrão a vida da classe média;

i) abolição de qualquer imposto ou taxa sobre os pequenos vendedores ambulantes de comestíveis e sobre as tendas de artesanato;

j) redução do imposto para os pequenos comerciantes;

k) industrialização e desenvolvimento das forças produtivas do País, abrindo perspectivas ao trabalho e ao emprego de capital por iniciativa particular, tendo em vista a libertação da economia nacional das formas de exploração colonizadora;

1) organização da economia agrária, segundo as circunstâncias peculiares a cada região, mas inspirada sempre no propósito de criar para a população rural condições que lhe proporcionem real elevação do nível de vida; criação de fazendas-escola e instituição da previdência social e adoção de medidas de assistência técnica e financeira ao agricultor, de modo que possa desenvolver a produção e libertar-se progressivamente do intermediário; abolição do aforamento.

A "Esquerda Democrática", proclamando constituírem tais reformas um dos pontos fundamentais do seu programa, reconhece que a estrutura agrária tradicional do País tem, desde a fase colonial, mantido a população rural num baixo nível de vida e impedido o desenvolvimento técnico das atividades agrícolas. Urge, portanto, modificá-la. A adoção das medidas sociais, técnicas e financeiras nesse sentido tem de ser precedida por estudos especializados, ainda hoje escassos e incompletos. A reorganização da economia agrária brasileira comporta, como um dos seus aspectos, vigoroso estímulo à pequena propriedade, inclusive pela distribuição de terras não aproveitadas, em zonas cultiváveis e acessíveis por sua situação relativamente aos centros de consumo, o que não exclui soluções de outra natureza.

A "Esquerda Democrática" declara-se convencida de que a restauração da normalidade econômico-financeira, como solução dos problemas sociais mais urgentes, exigirá medidas de tamanha importância que só um governo fortalecido pelo apoio popular será capaz de as pôr em prática, pacificamente. A incapacidade da política da ditadura conduziu o País a uma desordem financeira e administrativa tal que a solução de qualquer problema social, dos problemas especificamente econômicos, sobretudo, exigirá remédios drásticos. A opinião 
pública precisa ser energicamente advertida acerca das dificuldades que teremos de vencer, prevenindo-se contra o otimismo fácil e demagógico. $\mathrm{O}$ peso desses sacrifícios será particularmente duro para as camadas sociais economicamente menos favorecidas. Uma das tarefas a que a "Esquerda Democrática" se propõe é a de lutar para que o peso desses sacrifícios não recaia todo sobre a massa do povo.

Esse governo de confiança não poderá sair das entranhas da ditadura, sejam quais forem os adjetivos com que se enfeite a candidatura levantada pelo "continuísmo" em desespero, como tábua de salvação no seu naufrágio.

A candidatura Eduardo Gomes, ao contrário, nascida de um movimento de opinião nacional, apoiada por forças tradicionalmente opostas à ditadura e cercada, por isso mesmo, da confiança de todos os que têm combatido os desmandos da situação inaugurada em 10 de novembro de 1937, abre ao País perspectivas da mais sincera restauração democrática.

Quando ela surgiu espontaneamente do seio do povo, como um anseio das almas livres e antes que a União Democrática Nacional se houvesse constituído, os homens que formam a "Esquerda Democrática", aceitaram-na, desde logo, porque representava, por si mesma, o programa da democratização do Brasil e do repúdio total ao ditado de 10 de novembro de 1937.

Naqueles meses de fevereiro e março, não poderiam ser neutros entre o direito e o crime.

E, de fato, a candidatura Eduardo Gomes abre perspectivas de um regime que terá de viver do apoio popular e em que todos os que contribuem pelo trabalho para a formação da riqueza, libertado o trabalhador da opressão oficial em seus sindicatos, restituída ao intelectual a liberdade de opinião e assegurado a todos o direito de influir na direção dos negócios públicos.

Aí tem o povo as linhas ideológicas fundamentais do pensamento político da "Esquerda Democrática".

Um partido ou uma corrente política vale pelo nome que tenha ou pelo programa que adote; mas vale também pelos homens que o compõem e, sobretudo, o dirigem. Sua sinceridade e seu passado são as melhores garantias da atividade prática que hão de realizar, no presente e no futuro.

Dos signatários, deste manifesto, grande parte sofreu perseguições, prisões e condenações, por ter defendido, contra a reação policial e fascista que desde 1935 se apoderou do País, a liberdade do homem e o direito das massas populares. 
O povo neles pode confiar, porque, ao longo da vida, quase todos eles afirmaram, quando isso só lhes poderia custar contratempos e dissabores, que a ordem social vigente sacrifica a grande massa dos trabalhadores, manuais e intelectuais.

Assim, a "Esquerda Democrática", sem dissimular seu pensamento e seus fins, pleiteia uma ordem social melhor e transformações que reduzam as desigualdades artificiais de homem a homem, criadas pelos privilégios da riqueza.

Mas todas essas transformações ou reformas devem operar-se, democraticamente, pela vontade da maioria popular, expressa em urnas livres.

Eis por que somos da "Esquerda Democrática".

Nossas fileiras estão, assim, abertas a todos os que, sem outros objetivos, aceitem nosso programa.

A "Esquerda Democrática" não tem uma concepção filosófica de vida nem credo religioso; reconhece a cada um o direto de seguir, nessa matéria, a sua própria consciência. Nela cabem, assim, pessoas de todas as crenças e das filosofias mais diversas.

Daí o nosso apelo a todos os democratas de esquerda: que todos se congreguem na "Esquerda Democrática"; que se organizem, por todo o território nacional, comissões da "Esquerda Democrática".

O tempo urge. O mundo se transforma. E os privilégios estão a ruir.

Rio de Janeiro, 24 de agosto de 1945.

A comissão provisória: João Mangabeira - Hercolino Cascardo - Domingos Velasco - Alceu Marinho Rego - Edgardo de Castro Rebelo - Hermes Lima - Felipe Moreira Lima - Eliéser Magalhães - Elpídio Pessanha - Válter Peixoto - Rubem Braga - Antônio José de Schueler José Honório Rodrigues - Homero Pires - João Pedreira Filho - Celso de Figueiredo - Osório Borba - Juracy Magalhães - Arnon de Melo - A. Chagas Freitas - Joel Silveira - Mário Monteiro - José Luís de Araújo - Sérgio Buarque de Holanda - Guilherme Figueiredo - Fábio de Oliveira - Evandro Lins e Silva - Jurandir Pires Ferreira - Paulo Emílio Sales Gomes Francisco Martins de Almeida - Amarílio Vieira Cortez - Emil Fahrat - Alberto Pádua de 
Araújo - Luís Lins de Barros - Antero de Almeida - José Lins do Rego - Jader de Carvalho Juvêncio Campos - Silvio Maia Ferreira - Rui Barbosa de Melo - Raimundo Magalhães Júnior - Vítor do Espírito Santo - Carlos Amorety Osório - Carlos Castilho Cabral - João Ortiz Monteiro - Luís Rodolfo Cavalcanti de Albuquerque - Ari A. De Aragão - Carlos Pontes Moesia Rolim - Godofredo Moretzohn.

Fonte: <http://www.tse.jus.br/partidos/partidos-politicos/registros-de-partidos-politicos-1945-a-1979> 


\section{Anexo 4}

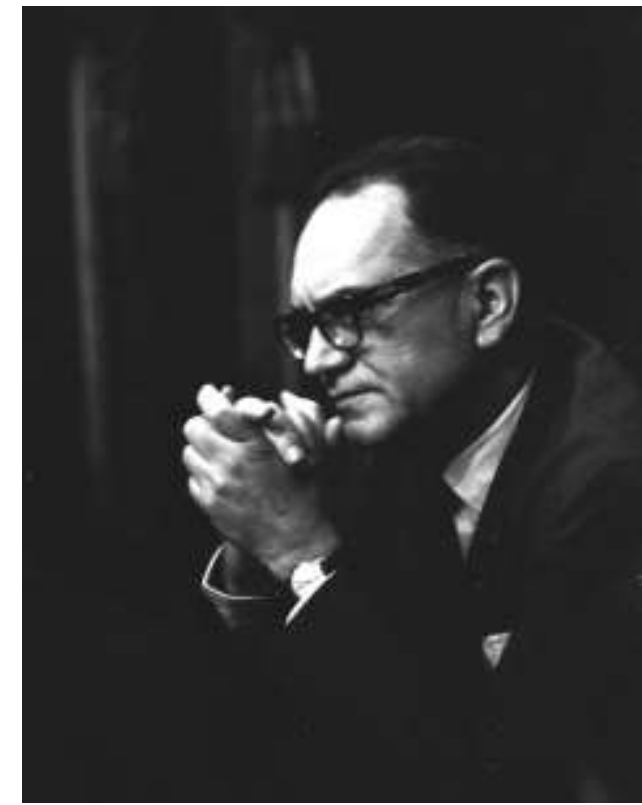

Hermes Lima, destacado deputado federal do PSB (Fonte: Erno Schneider/CPDOC/JB)

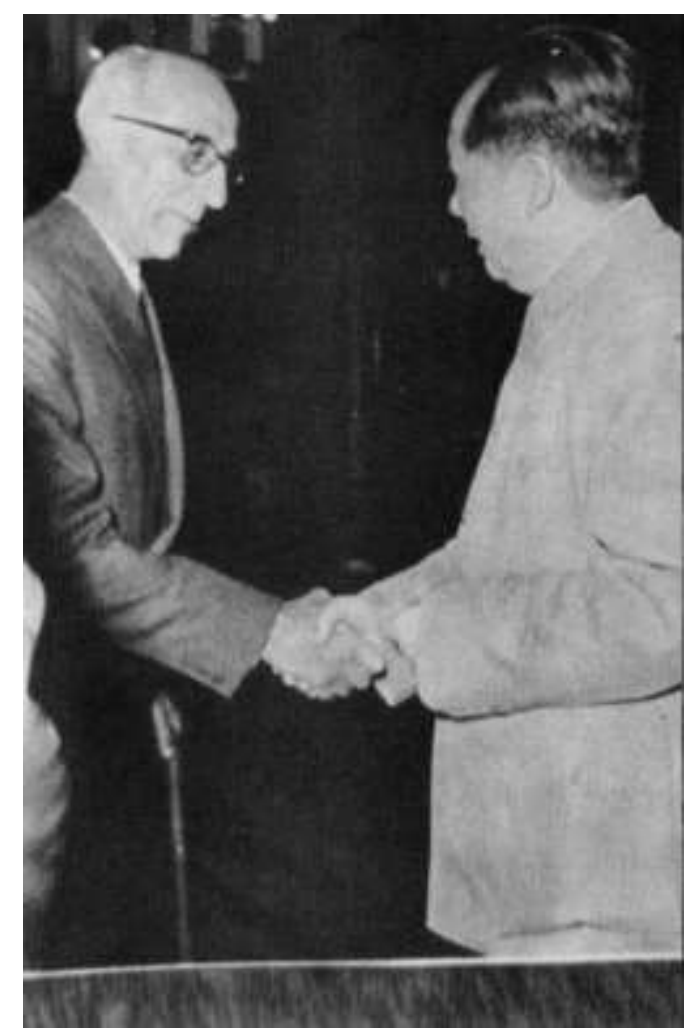

Domingos Vellasco cumprimenta Mao Tsé-Tung durante visita à República Popular da China (Fonte: Última Hora, 02.12.1956)

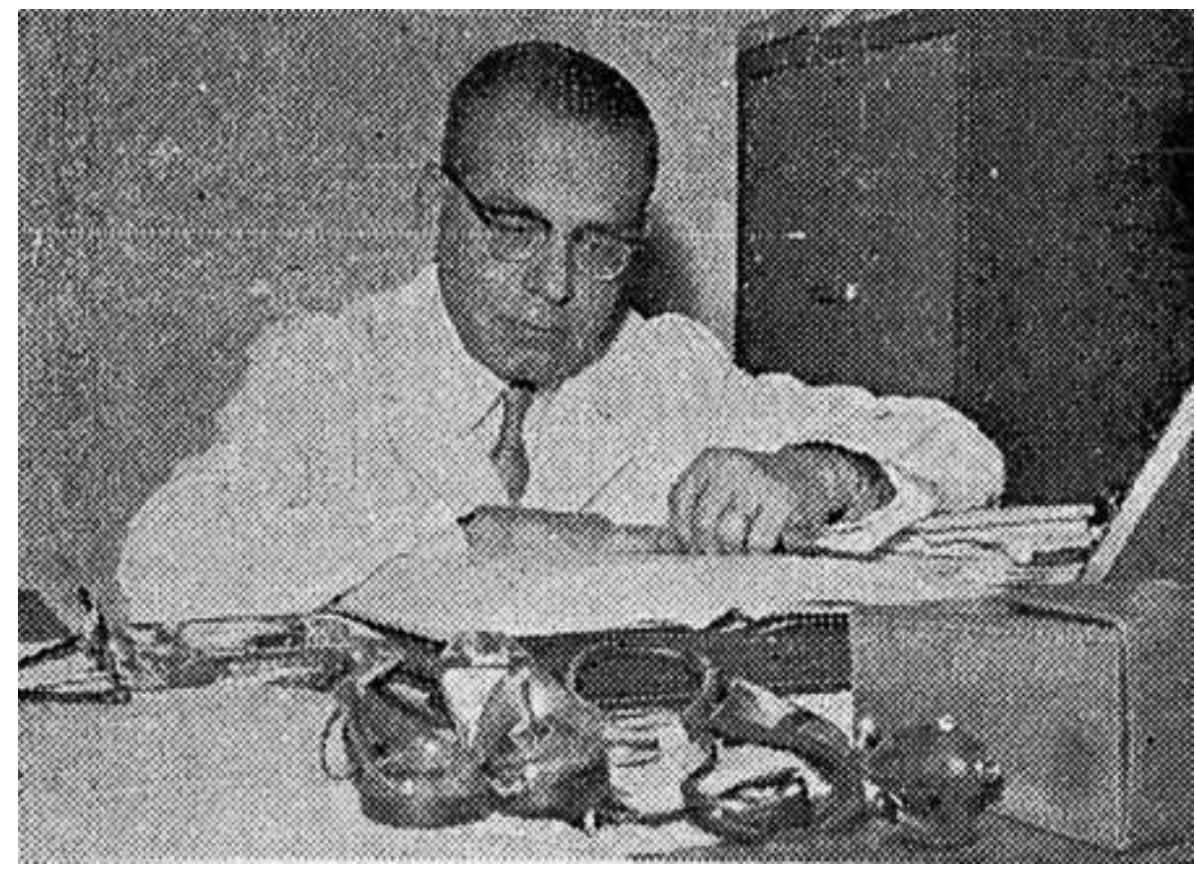

Febus Gikovate, médico e eminente teórico do PSB de São Paulo (Fonte: Diário de Notícias, 10.06.1958) 